\title{
DESIGN OF EFFICIENT CATALYSTS FOR STEAM REFORMING OF PYROLYSIS OIL TO HYDROGEN
}

Towards a green and sustainable future
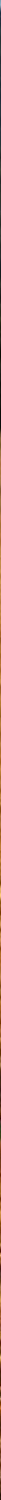


\section{Design of efficient catalysts for steam reforming of pyrolysis oil to hydrogen}

Towards a green and sustainable future 
Promotion committee

Prof. dr. M.J. Peters, chairman

Prof. dr. ir. L. Lefferts, promoter

Dr. K. Seshan, assistant-promoter

Prof. dr. J. G. E. Gardeniers

Prof.dr.ir. H.J. Heeres

Prof. U. Olsbye

Prof. dr. ir. W.P. M. Van Swaaij

Dr. J. W. Gosselink

Dr. S.R.A. Kersten
University of Twente, The Netherlands

University of Twente, The Netherlands

University of Twente, The Netherlands

University of Twente, The Netherlands

University of Groningen, The Netherlands

University of Oslo, Norway

University of Twente, The Netherlands

KSLA Amsterdam (Shell), The Netherlands

University of Twente, The Netherlands

The research described in this thesis was performed under the auspices of the NIOK, Netherlands Institute for Catalysis Research. Financial support by ACTS-NWO Project $\mathrm{n}^{\mathrm{o}}$ 053.61.007 is gratefully acknowledged.

Cover design: Ing. Bert Geerdink, Catalytic Processes and Materials (CPM), University of Twente, Enschede, The Netherlands

Cover picture: Berta Matas Güell

Publisher: Gildeprint, Enschede, The Netherlands

Copyright (C) 2009 by B. Matas Güell

No part of this work may be reproduced in any form without the prior permission of the author. 


\title{
DESIGN OF EFFICIENT CATALYSTS FOR STEAM REFORMING OF PYROLYSIS OIL TO HYDROGEN
}

TOWARDS A GREEN AND SUSTAINABLE FUTURE

\author{
PROEFSCHRIFT
}

ter verkrijging van

de graad van doctor aan de Universiteit Twente, op gezag van de rector magnificus,

prof. dr. H. Brinksma

volgens besluit van het College voor Promoties

in het openbaar te verdedigen

op vrijdag 9 oktober 2009 om 16.45 uur

door

Berta Matas Güell

geboren op 7 maart 1982

te La Bisbal d'Empordà, Catalonië 
This dissertation has been approved by the promoter

\author{
Prof. dr. ir. L. Lefferts
}

and the assistant-promoter

Dr. K. Seshan 
El geni comença les obres grans, però només el treball les acaba.

Joseph Joubert 
Genius begins great works;

labor alone finishes them.

Joseph Joubert 


\section{Contents}

$\begin{array}{ll}\text { Summary } & 1\end{array}$

Samenvatting 5

1 Introduction $\quad 11$

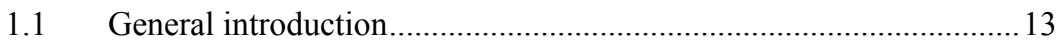

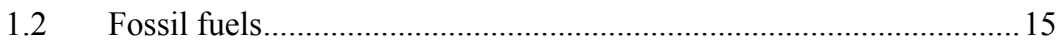

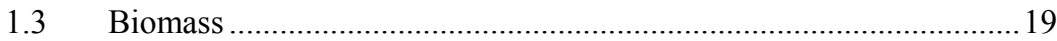

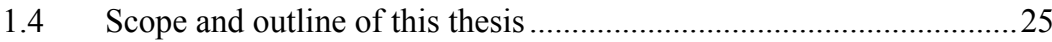

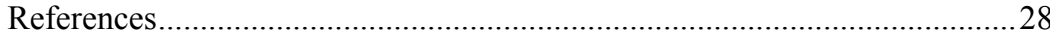

2 Acetic acid activation on supported-Pt catalysts 33

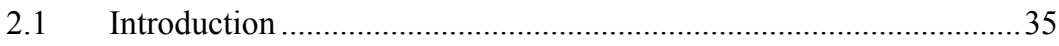

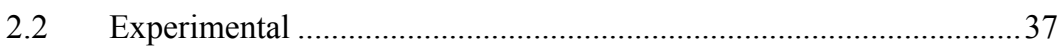

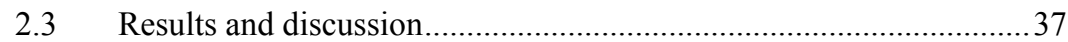

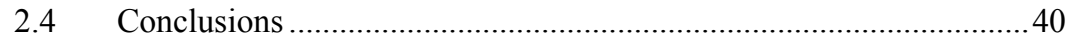

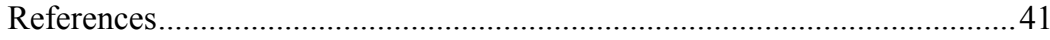

3 Steam reforming of acetic acid - Influence of $\mathrm{O}_{2}$ and red-ox supports 43

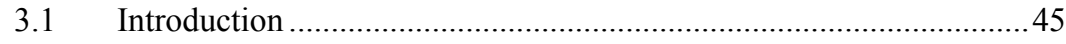

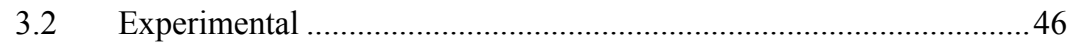

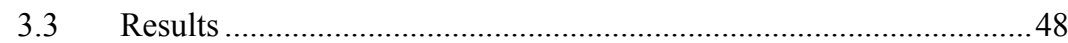

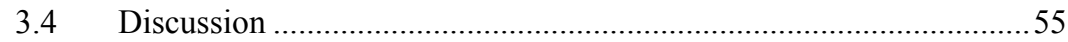

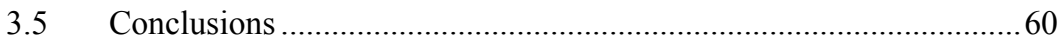

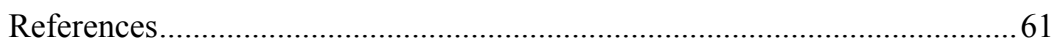


4 Steam reforming of acetic acid - Influence of La and K on Ni catalysts 63

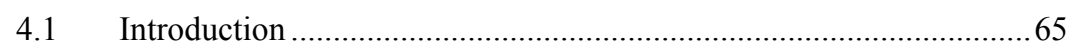

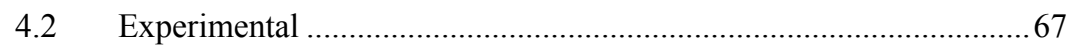

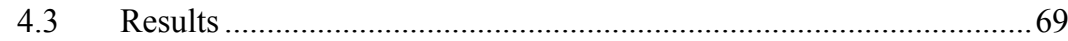

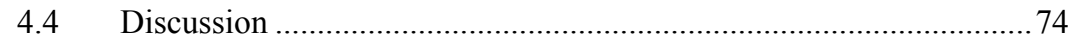

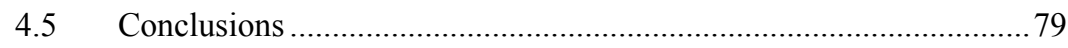

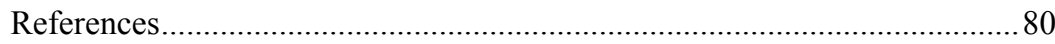

5 Steam reforming of phenol over Ni-based catalysts 83

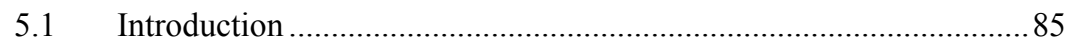

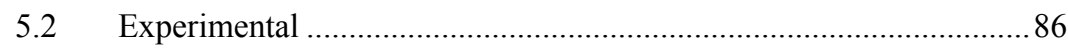

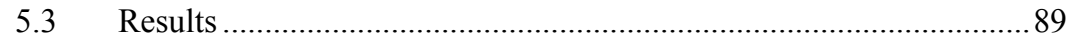

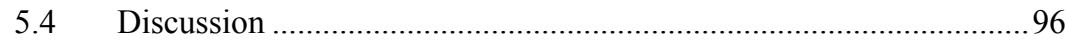

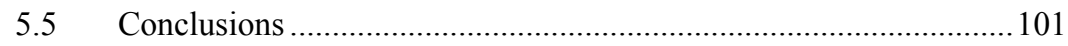

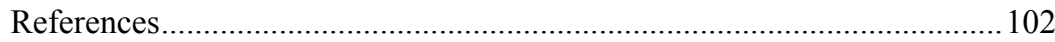

6 Char formed during pyrolysis oil evaporation 105

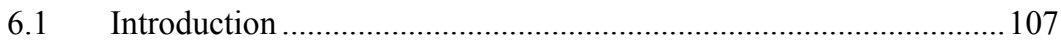

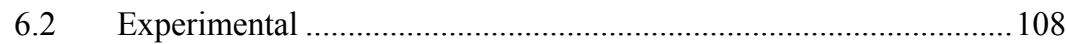

6.3 Results and discussion................................................................ 112

6.4 Implications for steam reforming of pyrolysis oil........................ 117

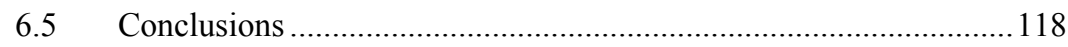

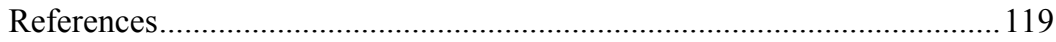

7 Catalytic steam and $\mathrm{CO}_{2}$ gasification of char from pyrolysis oil 121

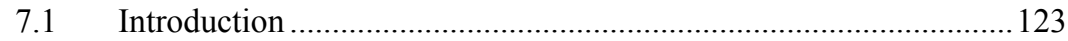

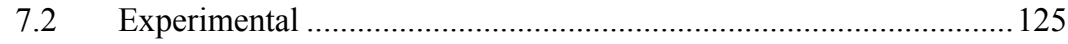

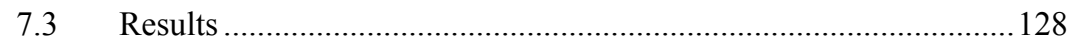


7.4 Discussion ................................................................................ 139

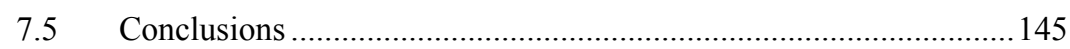

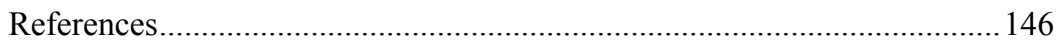

8 Conclusions and recommendations $\quad 149$

$\begin{array}{lr}\text { Publications } & 155\end{array}$

$\begin{array}{lr}\text { Acknowledgements } & 157\end{array}$ 



\section{Summary}

Currently, the world energy market is mostly met with fossil fuels. However, these conventional fuels result in excessive net carbon dioxide emissions and have serious geo-political implications, contributing negatively to environment, and security of supply. Therefore, there is a need for replacing the fossil fuels by alternative energy sources which are sustainable and renewable. Hydrogen, if produced from renewable sources such as waste biomass, is recognized as a clean fuel and energy carrier and will certainly play a key role in the future society and economy. Currently, however, hydrogen is mostly produced from non-renewable natural gas via steam reforming and gasification of naphtha or as by-product in refinery conversions.

The research described in this thesis focuses on the production of hydrogen from biomass-based feedstocks as renewable sources; particularly, via the catalytic steam reforming of pyrolysis oil. Pyrolysis oil, which is produced by the thermal cracking of wood, consists of a large number and variety of oxygenated components. Due to the complexity of this feedstock, it is too difficult to draw relations between structure, properties and reaction mechanism which is essential in the development of efficient catalysts for the conversion of pyrolysis oil. The choice of simple representative molecules present in pyrolysis oil simplifies these structure-properties-mechanism relations.

In the first part of the dissertation, the steam reforming of acetic acid as a model component of light oxygenates present in pyrolysis oil was investigated over platinum-based and nickel-based catalysts. In Chapter 2, a detailed isotopic study of deuterated acetic acid over a $\mathrm{Pt} / \mathrm{C}$ catalyst is presented to probe the route to the activation of acetic acid during steam reforming over platinum-based catalysts and substantiate the bifunctional mechanism suggested earlier for the steam reforming of acetic acid over a $\mathrm{Pt} / \mathrm{ZrO}_{2}$ catalyst. The product mixture contained $\mathrm{CO}_{2}, \mathrm{CH}_{4}$ and its 
D-analogs $\left(\mathrm{CH}_{4-\mathrm{x}} \mathrm{D}_{\mathrm{x}}, 0 \leq \mathrm{x} \leq 4\right), \mathrm{H}_{2}, \mathrm{HD}$ and $\mathrm{D}_{2}$. Our observations suggested that acetic acid activation occurs via $\mathrm{C}-\mathrm{C}$ cleavage, producing $\mathrm{CO}_{2}, \mathrm{CH}_{3} \mathrm{D}$ and $\mathrm{D}_{2}$ as primary desorption products. The rest of the gas mixture was formed via hydrogen redistribution reactions and $\mathrm{H}-\mathrm{D}$ exchange of the primary species. $\mathrm{CH}_{\mathrm{x}}$ specie $(0 \leq \mathrm{x} \leq 3)$ formed on the platinum surface were suggested to be further steam reformed in the presence of steam.

Chapter 3 describes the influence of the support and the presence of oxygen in the steam reforming of acetic acid over $\mathrm{Pt} / \mathrm{ZrO}_{2}$ and $\mathrm{Pt} / \mathrm{CeO}_{2}$ catalysts. Our findings demonstrate that the nature of the support has a strong influence on the catalyst stability in the steam reforming of $\mathrm{AcOH} . \mathrm{Pt} / \mathrm{ZrO}_{2}$ in the absence of oxygen suffered significantly from deactivation due to accumulation of carbonaceous deposits originating from acetone. Acetone is one of the intermediates formed from $\mathrm{AcOH}$ during steam reforming. Our catalytic results also revealed that $\mathrm{Pt} / \mathrm{ZrO}_{2}$ deactivated for the steam reforming of acetone to a large extent. The presence of small amounts of oxygen in the feed improved the stability of $\mathrm{Pt} / \mathrm{ZrO}_{2}$ to a certain extent, but not sufficient enough for application. MALDI-TOF MS characterization of coke formed indicated that the presence of oxygen prevents extensive oligomerization/aging and that the resulting species are more easily combusted. On the other hand, $\mathrm{Pt} / \mathrm{CeO}_{2}$ showed excellent stability for the steam reforming of acetic acid under oxidative conditions and for the steam reforming of acetone in the absence of oxygen. It was proposed that the combination of (i) enhanced steam reforming activity of acetone (coke precursor), (ii) oxygen addition to the steam reforming feed and (iii) the red-ox characteristics of $\mathrm{CeO}_{2}$ to use both oxygen and water as oxidants was key to justify the excellent catalytic stability of $\mathrm{Pt} / \mathrm{CeO}_{2}$.

Alternatively, steam reforming of acetic acid has been studied over nickel-based catalysts, as discussed in Chapter $4 . \mathrm{Ni} / \mathrm{ZrO}_{2}$ exhibited high activity. However, it gradually deactivated in time. Calculations concerning the water-gas equilibrium suggested that catalyst deactivation has a major impact on the water-gas shift reaction. Coke formation as well as a competitive adsorption of reactants was suggested to be responsible for the catalyst deactivation. Modification of the $\mathrm{Ni} / \mathrm{ZrO}_{2}$ catalyst with potassium and/or lanthanum resulted in lower amounts of coke deposit, thus improving the catalyst lifetime to a large extent. Addition of potassium was suggested 
to enhance gasification of carbonaceous species by facilitating the formation of reactive hydroxyl groups and lanthanum was proposed to enhance coke combustion with the help of an oxy-carbonate phase $\left(\mathrm{La}_{2} \mathrm{O}_{2} \mathrm{CO}_{3}\right)$ formed during reaction.

The second part of this thesis addresses the steam reforming of phenol as a representative component of heavy oxygenates present in pyrolysis oil. Hence, this section deals with a model component which presents higher complexity than acetic acid and is therefore closer to the real structure of pyrolysis oil. Chapter 5 compares the steam reforming of phenol over two catalysts: (i) a catalyst successfully designed for the steam reforming of acetic acid $\left(\mathrm{Ni} / \mathrm{K}-\mathrm{La}-\mathrm{ZrO}_{2}\right)$ and (i) a novel nickel-ceria-zirconia-based catalyst $\left(\mathrm{Ni} / \mathrm{Ce}-\mathrm{ZrO}_{2}\right)$. Both catalysts exhibited high activity and good stability in terms of phenol conversion. However, Ni/K-La- $\mathrm{ZrO}_{2}$, in contrast to $\mathrm{Ni} / \mathrm{Ce}-\mathrm{ZrO}_{2}$, showed a pronounced change in product distribution in time which was suggested to be the result of deactivation of the catalyst function for the water-gas shift reaction. Based on our catalytic and characterization results it was proposed that the location of the carbonaceous deposits on the catalyst surface and the excellent activity of unsupported nickel for the water-gas shift were key to explain the difference in catalyst stability between $\mathrm{Ni} / \mathrm{K}-\mathrm{La}-\mathrm{ZrO}_{2}$ and $\mathrm{Ni} / \mathrm{Ce}-\mathrm{ZrO}_{2}$. Further, it was speculated that the red-ox properties of the $\mathrm{Ce}-\mathrm{ZrO}_{2}$ allow nickel surface to remain clean from carbonaceous deposits in the case of $\mathrm{Ni} / \mathrm{Ce}-\mathrm{ZrO}_{2}$, and therefore is able to perform the water-gas shift reaction without suffering from deactivation. In contrast, $\mathrm{K}-\mathrm{La}-\mathrm{ZrO}_{2}$ does not possess red-ox capability and therefore the nickel surface is covered with carbonaceous deposits to a large extent, resulting in catalyst deactivation for the water-gas shift reaction.

The last part of the thesis introduces the real life problem of char formed during pyrolysis oil evaporation and presents new catalytic solutions to the problems associated to it. In Chapter 6, properties of char as well as the influence of temperature on its production/reactivity is evaluated. Furthermore, implications of the obtained results on designing a process for gasification / steam reforming of pyrolysis oil are also here discussed. Our observations indicated that pyrolysis oil evaporation is always coupled with the formation of char. Characterization results revealed that char consists of a very open structure, which results in elutriation with gas streams from the reactor if char is not sufficiently bound to a carrier. Char showed an aging 
behavior at higher temperatures $\left(\geq 650-700^{\circ} \mathrm{C}\right)$, resulting in a less reactive char. The reactivity of char during steam gasification was too low at the target temperature range $\left(500-700{ }^{\circ} \mathrm{C}\right)$ for pyrolysis oil evaporation, strongly suggesting the need of a catalyst for the process.

Chapter 7 reports on the development of such catalysts and catalytic performance of a ceria-zirconia-based catalyst for (i) steam $/ \mathrm{CO}_{2}$ gasification and (ii) combustion of char. These results are compared with those obtained in the non-catalytic scenario for the temperature range $600-800{ }^{\circ} \mathrm{C}$. Kinetic studies revealed that the presence of the ceria-zirconia catalyst enhanced char gasification rates significantly, up to one order of magnitude at the higher temperatures, for both steam and $\mathrm{CO}_{2}$ gasification. The role of the catalyst was suggested to provide oxygen for char gasification, resulting in oxygen vacancies, and activate steam and $\mathrm{CO}_{2}$ to self regenerate the oxygen vacancies formed. Furthermore, XPS and SEM characterization studies showed that the catalyst also influenced the nature of char formed during pyrolysis oil evaporation to a great extent, by forming more oxygenated char which is more reactive. It was also shown that a good contact between char and catalyst is essential for the catalytic enhancement in char gasification. Therefore, our findings convincingly demonstrated that pyrolysis oil evaporation in combination with internal catalytic char gasification is feasible at relatively low temperatures $\left(\leq 700{ }^{\circ} \mathrm{C}\right)$.

The findings in this thesis, namely; (i) development of stable and active catalysts for the steam reforming of model components representing lighter and heavier components in pyrolysis oil and (ii) method to convert char, that is formed inevitably during the evaporation of pyrolysis oil, in-situ, via an additional steam/ $\mathrm{CO}_{2}$ reforming, provides scope for the development of a catalytic process for efficient conversion of biomass to hydrogen which was the target of this study. 


\section{Samenvatting}

Vandaag de dag wordt de wereldenergiemarkt voorzien van fossiele brandstoffen. Echter, deze conventionele brandstoffen resulteren in een overmatige netto koolstofdioxide-emissie en hebben grote geopolitieke gevolgen, met negatieve effecten op het milieu en op de zekerheid van levering. Daarom is het noodzakelijk fossiele brandstoffen te vervangen door alternatieve energiebronnen die duurzaam en herwinbaar zijn. Waterstof is erkend als een schone brandstof en energiedrager, indien het geproduceerd is uit een herwinbare bron zoals biomassa-afval en zal zeker een belangrijke rol spelen in een toekomstige samenleving en economie. Echter, op dit moment wordt waterstof grotendeels geproduceerd uit niet herwinbaar aardgas via stoomreformen en uit vergassing van nafta of, als een bijproduct, bij raffinage conversieprocessen.

Het onderzoek dat in dit proefschrift beschreven staat, richt zich op de productie van waterstof uit biomassavoedingen als herwinbare bronnen, in het bijzonder via katalytisch stoomreformen van pyrolyse-olie. Pyrolyse-olie, een product van het thermisch kraken van hout, bestaat uit een grote hoeveelheid geoxygeneerde componenten, waarbinnen ook een grote variëteit aanwezig is. Omdat deze biomassavoedingen zo complex zijn, is het erg moeilijk relaties te leggen tussen de structuur, eigenschappen en reactiemechanismen. Het ontrafelen van deze relaties is van groot belang voor de ontwikkeling van efficiënte katalysatoren voor de omzetting. Het bestuderen van simpele, representatieve moleculen die aanwezig zijn in de pyrolyse-olie vereenvoudigt het onderzoeken van de relaties tussen structuur, eigenschappen en mechanismes.

In het eerste gedeelte van dit proefschrift wordt het stoomreformen van azijnzuur, als zijnde een licht geoxygeneerde modelcomponent, over platinum- en nikkelgebaseerde katalysatoren bestudeerd. In Hoofstuk 2 wordt een gedetailleerde isotopenstudie over gedeuteriseerd azijnzuur met een $\mathrm{Pt} / \mathrm{C}$ katalysator gepresenteerd. 
Doel was enerzijds de activeringsroute van azijnzuur over Pt-gebaseerde katalysatoren tijdens het stoomreformen te achterhalen en anderzijds om het eerder voorgestelde bifunctionele mechanisme van het stoomreformen van azijnzuur over een $\mathrm{Pt} / \mathrm{ZrO}{ }_{2}$ katalysator te beargumenteren. De productsamenstelling bevatte $\mathrm{CO}_{2}, \mathrm{CH}_{4}$ en zijn D-analogen $\left(\mathrm{CH}_{4-\mathrm{x}} \mathrm{D}_{\mathrm{x}}, 0 \leq \mathrm{x} \leq 4\right), \mathrm{H}_{2}, \mathrm{HD}$ en $\mathrm{D}_{2}$. Onze observaties gaven aan dat azijnzuur wordt geactiveerd via $\mathrm{C}-\mathrm{C}$ splitsing waarbij $\mathrm{CO}_{2}, \mathrm{CH}_{3} \mathrm{D}$ en $\mathrm{D}_{2}$ als primaire desorptieproducten worden gevormd. De rest van het gasmengsel werd gevormd via waterstof-herverdelingsreacties en $\mathrm{H}$-D uitwisseling met de primaire producten. $\mathrm{CH}_{\mathrm{x}}$ componenten $(0 \leq \mathrm{x} \leq 3)$ die gevormd worden op het platinumoppervlakte vervolgens verder stoomgereformd worden met behulp van $\mathrm{H}_{2} \mathrm{O}$.

In Hoofdstuk 3 wordt de invloed van de drager en de aanwezigheid van zuurstof in het stoomreformen van azijnzuur over $\mathrm{Pt} / \mathrm{ZrO}_{2}$ en $\mathrm{Pt} / \mathrm{CeO}_{2}$ katalysatoren beschreven. Onze bevindingen laten zien dat het type drager een sterke invloed heeft op de stabiliteit van de katalysator tijdens het stoomreformen van azijnzuur. $\mathrm{Pt} / \mathrm{ZrO} 2$ ondervond significante deactivatie wanneer er geen zuurstof aanwezig was door ophoping van koolstofhoudende afzettingen afkomstig van aceton. Aceton is een van de tussenproducten van de omzetting van azijnzuur door stoomreformen. Onze katalytische resultaten toonden ook aan dat $\mathrm{Pt} / \mathrm{ZrO}_{2}$ grotendeels deactiveert door het stoomreformen van aceton. De aanwezigheid van kleine hoeveelheden zuurstof in de voeding zorgden voor een verbeterde stabiliteit van $\mathrm{Pt} / \mathrm{ZrO}_{2}$, echter niet genoeg voor daadwerkelijke toepassing. MALDI-TOF MS karakterisering van de gevormde kool liet zien dat de aanwezigheid van zuurstof extensieve oligomerisatie/veroudering voorkwam en dat de gevormde componenten gemakkelijker af te branden waren. Anderzijds liet $\mathrm{Pt} / \mathrm{CeO}_{2}$ excellente stabiliteit zien tijdens het stoomreformen van azijnzuur in een oxiderende omgeving en tijdens het stoomreformen van aceton bij afwezigheid van zuurstof. De excellente katalytische activiteit van $\mathrm{Pt} / \mathrm{CeO}_{2}$ was het gevolg van een combinatie van (i) versterkte stoomreform activiteit van aceton (kool precursor), (ii) zuurstof toevoeging aan de stoomreform voeding en de (iii) red-ox eigenschappen van $\mathrm{CeO}_{2}$ om zowel zuurstof als water te gebruiken als oxidanten.

Daarnaast is het stoomreformen van azijnzuur bestudeerd over Ni-gebaseerde katalysatoren, hetgeen is weergegeven in Hoofdstuk 4. Ni/ZrO $\mathrm{ZO}_{2}$ vertoonde een zeer hoge activiteit. Echter, het deactiveerde geleidelijk in tijd. Berekeningen aan het 
water-gas evenwicht maakte aannemelijk dat deactivatie van de katalysator een grote invloed heeft op de water-gas uitwisselingsreactie. Zowel koolvorming als competitieve absorptie van de reactanten werden voorgesteld als zijnde verantwoordelijk voor katalysator deactivatie. Het modificeren van de $\mathrm{Ni} / \mathrm{ZrO}_{2}$ katalysator met kalium en/of lanthanium resulteerde in kleinere hoeveelheden koolafzetting, waarmee de levensduur van de katalysator aanzienlijk werd verlengd. Toevoeging van kalium was waarschijnlijk verantwoordelijk voor een versnelde vergassing van koolhoudende fracties door middel van het faciliteren van de vorming van reactieve hydroxielgroepen en van lanthanium door het versnellen van koolverbranding met behulp van een oxy-carbonaat fase $\left(\mathrm{La}_{2} \mathrm{O}_{2} \mathrm{CO}_{3}\right)$ die gevormd wordt tijdens de reactie.

Het tweede gedeelte van dit proefschrift gaat over het stoomreformen van fenol als een representatieve component van de zware geoxygeneerden die aanwezig zijn in de pyrolyse-olie. Fenol kan gelden als een modelcomponent die een hogere complexiteit heeft dan azijnzuur en daarom dichterbij de echte structuur ligt van pyrolyse-olie. Hoofdstuk 5 vergelijkt het stoomreformen van fenol over twee katalysatoren: (i) een katalysator die met succes is ontworpen voor het stoomreformen van azijnzuur $\left(\mathrm{Ni} / \mathrm{K}-\mathrm{La}-\mathrm{ZrO}_{2}\right)$ en (ii) een nieuwe nikkel-cerium-zirkonium gebaseerde katalysator $\mathrm{Ni} / \mathrm{Ce}-\mathrm{ZrO}_{2}$. Beide katalysatoren lieten een hoge activiteit en goede stabiliteit zien voor fenolconversie. Echter, Ni/K-La- $\mathrm{ZrO}_{2}$, in tegenstelling tot $\mathrm{Ni} / \mathrm{Ce}-\mathrm{ZrO}_{2}$, liet een uitgesproken verandering in productverdeling in tijd zien die waarschijnlijk het gevolg is van deactivatie van de katalysatorfunctie voor de water-gas uitwisselingsreactie. Gebaseerd op onze katalytische- en karakteriseringresultaten werd voorgesteld dat de locatie van de koolafzetting op het katalysatoroppervlakte en de excellente activiteit van los nikkel voor de water-gas uitwisseling de sleutel vormen om het verschil te verklaren tussen de katalytische stabiliteit van $\mathrm{Ni} / \mathrm{K}-\mathrm{La}-\mathrm{ZrO}_{2}$ en van $\mathrm{Ni} / \mathrm{Ce}-\mathrm{ZrO}_{2}$. Daarnaast wordt er gespeculeerd dat de red-ox eigenschappen van het $\mathrm{Ce}-\mathrm{ZrO}_{2}$ het nikkeloppervlak vrij houden van koolafzettingen voor $\mathrm{Ni} / \mathrm{Ce}-\mathrm{ZrO}_{2}$, en daarom in staat zijn om de water-gas uitwisselingsreactie uit te voeren zonder onderhevig te zijn aan deactivatie. Daarentegen heeft $\mathrm{K}-\mathrm{La}-\mathrm{ZrO}_{2}$ geen red-ox capaciteit en is het nikkeloppervlak voor 
een groot gedeelte bedekt met koolafzettingen hetgeen resulteert in katalysatordeactivatie voor de water-gas uitwisselingsreactie.

In het laatste gedeelte van dit proefschrift wordt het in de realiteit optredende probleem van koolvorming tijdens pyrolyse-olie verdamping geïntroduceerd en worden nieuwe katalytische oplossingen gepresenteerd voor de daarbij behorende problemen. In hoofstuk 6 worden de eigenschappen van kool en de invloed van temperatuur op de productie/reactiviteit geëvalueerd. Daarnaast worden ook de implicaties van de verkregen resultaten voor een procesontwerp voor het vergassen/stoomreformen van pyrolyse-olie besproken. Onze observaties laten zien dat verdamping van pyrolyse-olie altijd vergezeld gaat met de vorming van kool. Karakteriseringresultaten lieten zien dat de kool bestaat uit een heel open structuur hetgeen resulteert in meevoering met gasstromen uit de reactor als de kool niet adequaat gebonden is aan een drager. De kool liet verouderingsgedrag zien bij hoge temperaturen $\left(\geq 650-700{ }^{\circ} \mathrm{C}\right)$ hetgeen resulteerde in minder reactieve kool. De reactiviteit van kool tijdens het stoomvergassen bij het beoogde temperatuurbereik voor verdamping van pyrolyse-olie $\left(500-700{ }^{\circ} \mathrm{C}\right)$ was te laag. Hiermee was de noodzaak aangetoond van een katalysator voor het proces.

Hoofdstuk 7 beschrijft de ontwikkeling van dergelijke katalysatoren en de katalytische prestatie van een cerium-zirkonium gebaseerde katalysator voor (i) stoom $/ \mathrm{CO}_{2}$-vergassing en (ii) verbranding van kool. Deze resultaten worden vergeleken met het niet katalytische scenario in het temperatuur bereik van $600-800^{\circ} \mathrm{C}$. Kinetische studies lieten zien dat de aanwezigheid van een cerium-zirkonium katalysator de snelheid van koolvergassing bij hogere temperaturen significant versnelt tot een orde grootte, voor zowel stoom- als $\mathrm{CO}_{2}$-vergassing. De rol van de katalysator is waarschijnlijk dat het zuurstof levert voor de koolvergassing, hetgeen resulteert in zuurstofleegtes, en dat het stoom en $\mathrm{CO}_{2}$ activeert om zelf de zuurstofleegtes te regenereren. Daarnaast lieten XPS en SEM karakteriseringstudies zien dat de katalysator ook een grote invloed heeft op het type kool dat gevormd wordt tijdens pyrolyse-olie verdamping door meer geoxygeneerde kool te vormen die reactiever is. Er werd ook aangetoond dat een goed contact tussen de kool en de katalysator noodzakelijk is voor de katalytische versnelling van de koolvergassing. Onze bevindingen laten daarom overtuigend zien dat verdamping van pyrolyse-olie in 
combinatie met interne katalytische koolvergassing haalbaar is bij relatief lage temperaturen $\left(\leq 700^{\circ} \mathrm{C}\right)$.

De bevindingen in deze studie, namelijk (i) de ontwikkeling van stabiele en actieve katalysatoren voor het stoomreformen van modelcomponenten representatief voor lichtere en zwaardere componenten in de pyrolyse-olie en (ii) een methode om kool, die onvermijdelijk wordt gevormd tijdens de verdamping van pyrolyse-olie, in-situ om te zetten via additioneel stoom $/ \mathrm{CO}_{2}$-reformen, geven uitzicht op de ontwikkeling van katalytische processen voor een efficiënte omzetting van biomassa naar waterstof wat het doel was van deze studie. 



\section{Chapter 1}

\section{Introduction}

Currently, the world energy market is mostly met with fossil fuels. However, these conventional fuels result in excessive net carbon dioxide emissions and have serious geo-political implications, contributing negatively to environment and security of supply. Therefore, there is a need for replacing the fossil fuels by alternative energy sources which are sustainable and renewable. Hydrogen, if produced from renewable sources such as waste biomass, is recognized as a clean fuel and energy carrier and will certainly play a key role in the future society and economy. Currently, however, hydrogen is mostly produced from non-renewable natural gas via steam reforming and gasification of naphtha or as by-product in refinery conversions. 



\subsection{General introduction}

It is generally accepted that the world energy consumption will expand the coming decades by at least a factor of 1.5 by 2030 or about 2 by 2050 [1-3], as a result of rapid growth in population and industrialization development. Currently, the world energy market is mostly met with fossil fuels. However, these conventional fuels reserves are being depleted rapidly. Depending on the projections in energy demand, World's oil reserves are estimated to be exhausted by 2030-2050 [4, 5]. Furthermore, fossil fuels have serious geo-political implications, as their reserves are essentially located in few areas, contributing negatively to security of supply. Additionally, fossil fuels contribute to green house gas emissions, which expose our planet to danger [6-8]. According to The Intergovernmental Panel on Climate Change (IPCC 2007) the increase of $\mathrm{CO}_{2}$ content in the atmosphere as a result of combustion of fossil fuels [9] is now accepted as the dominant cause for global warming. Therefore there is a need for replacing the fossil fuels by alternative energy sources which are renewable and do not pollute the earth. Further, there are a variety of fossil fuels, such as gasoline, liquefied petroleum gas (LPG), diesel, kerosene, etc., used currently. The use of one unique energy carrier, in contrast to the large variety of fuels used at present, would be more efficient especially in terms of infrastructure for transport, storage and use. In this respect, hydrogen, which is a good energy carrier, is considered as a promising candidate. Veziroğlu et al. [6] carried out a detailed comparison between hydrogen and fossil fuels. They concluded that hydrogen is the best fuel candidate in terms of safety, versatility, transportation and efficiency. Hydrogen-based fuel cells, for instance, offer an enormous advantage in terms of efficiency when compared to the Carnot engine for power production or mobile applications. Hydrogen production has been increased during the last years, as shown in Fig. 1.1. The current hydrogen price is about $2200 \$ /$ ton.

Hydrogen, if produced from renewables, has the potential to overcome the main two problems associated to fossil fuels: reduce dependence on petroleum and reduce pollution by minimizing greenhouse gas emissions [10-12]. Currently, hydrogen is mostly derived from non renewable natural gas via steam reforming and via gasification of naphtha in a refinery. However a large number of recent investigations 
show promise in the production of hydrogen from renewable sources such as biomass-based feedstocks [14-16].

The demand for hydrogen as a fuel is growing in interest, especially in the field of fuel cells, as illustrated in Fig. 1.2 [17]. These systems have been identified as the most attractive and promising technologies for clean

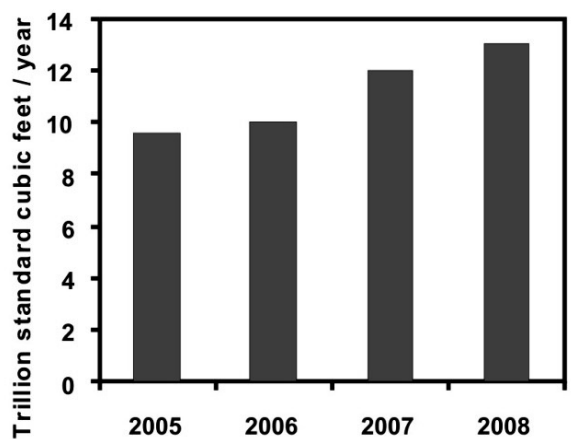

Fig. 1.1. Worldwide total hydrogen production between 2005 and 2008. Adapted from [13]. energy generation [18]. One definite example of fuel cell applications is in the discipline of automotives [19, 20]. Several major car producers such as General Motors, Toyota, Honda, Mercedes-Benz, etc. have already initiated a shift towards production of hydrogen powered vehicles. However, there are still open challenges remaining, among which hydrogen storage is

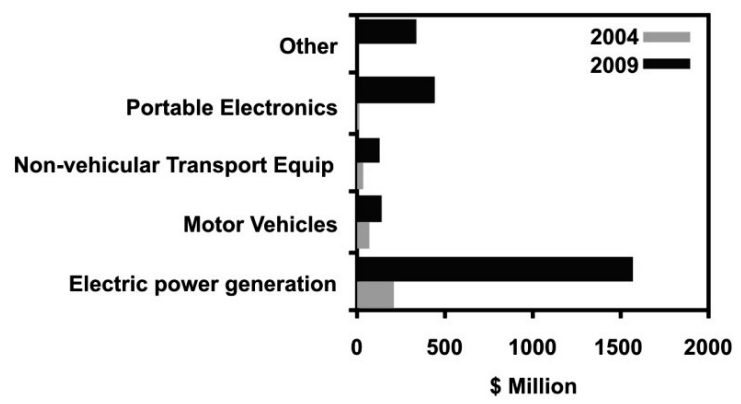

Fig. 1.2. World fuel cell demand growth. Comparison between 2004 and 2009. Adapted from [17]. a major one, mainly attributed to higher costs and lower energy density as compared to the conventional gasoline or diesel tanks [21]. Therefore further research is required in this domain.

Hydrogen is also an important raw material for the chemical and refining industries, for the production of ammonia and for the hydrotreating processes such as hydrodesulfurization, hydrodeoxygenation, hydrodenitrogenation and hydrocracking [22-24]. 


\subsection{Fossil fuels}

\subsubsection{Reforming of natural gas and higher hydrocarbons.}

Steam reforming of natural gas is a proven and widely used technology for the production of hydrogen $[11,25,26]$. The first industrial steam reformer was installed in 1930 [26]. Most of the process was in the United States where natural gas was abundantly available. Later on, however, natural gas reserves were discovered in Europe and natural gas was used as feedstock for hydrogen

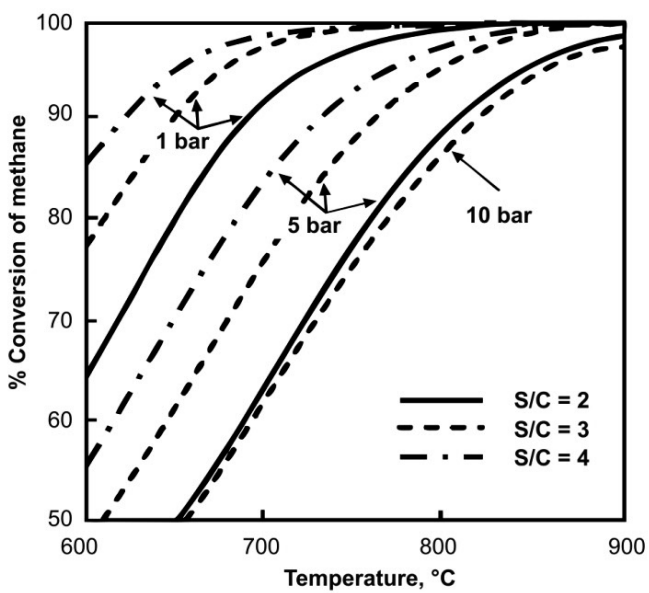

Fig. 1.3. Steam reforming of methane. Equilibrium conversion as a function of temperature, pressure and steam/carbon ratio [27].

production.

Steam reforming is a strongly endothermic reaction (Eq. 1.1). In order to ensure a high methane conversion it is therefore required to operate at elevated temperatures.

$$
\mathrm{CH}_{4}+\mathrm{H}_{2} \mathrm{O} \rightleftarrows \mathrm{CO}+3 \mathrm{H}_{2} \quad \Delta H_{298}^{0}=206.3 \mathrm{~kJ} \cdot \mathrm{mol}^{-1}
$$

Additionally, steam reforming is, in practice, reversible. Therefore, according to Le Chatelier's Principle, low pressures and relatively high steam to carbon ratios will shift the equilibrium, increasing methane conversion, as illustrated in Fig. 1.3 $[27,28]$.

Methane, particularly, is extremely difficult to activate, as the hydrogen-carbon bonds are strong (435 kJ.mol ${ }^{-1}$ [29]) and therefore cleavage of the corresponding hydrogen-carbon bonds requires very high temperatures. The presence of a catalyst, however, allows for milder conditions as it enhances the hydrogen-carbon bond rupture. The metals of group VIII of the periodic table are active for steam reforming and particularly nickel appears to be the most cost-effective [26, 27]. Industry 
typically operates this process at around $800{ }^{\circ} \mathrm{C}, 15-40$ bar and steam to carbon ratios of 2-3 over nickel-based catalysts [30,31]. Although the presence of a catalyst makes the process technically more feasible as compared to non-catalytic conditions, the elevated temperatures applied often result in large energy consumption. The relatively large amounts of steam used in the reforming process also decrease the overall process efficiency. This can be explained by the significant heating and cooling steps required to recycle the unconverted steam. Although high steam to carbon ratios result in high energy consumption, large amounts of steam are essential to overcome catalyst deactivation due to coke formation. Coking, which is a side reaction in many industrial processes, is a major issue and still needs attention. Besides resulting in catalyst deactivation it also causes serious operational problems [32, 33]. Particularly, $\mathrm{Ni}$ is known to be very susceptible to coking. This makes the design of an active and stable catalyst a challenging task. In this context, extensive research has been carried out. An excellent review by Rostrup-Nielsen discusses coking during steam reforming in detail. Addition of promoters over catalysts has been widely reported as a successful tool to improve the catalytic properties in terms of activity and stability [34-36]. Numerous studies have been done on the effect and role of potassium [37-39] on the properties of unmodified catalysts and it is widely accepted that the presence of an alkali improves resistance to coking by assisting in the formation of $\mathrm{OH}$ groups on oxide supports which enhance coke gasification. Some other authors have reported on the beneficial influence of lanthanum as a promoter in the improvement of catalyst stability for reforming reactions [36]. In the case of dry reforming, lanthanum is suggested to react with $\mathrm{CO}_{2}$ forming a new crystalline phase $\left(\mathrm{La}_{2} \mathrm{O}_{2} \mathrm{CO}_{3}\right)$ which provides oxygen from its structure and in this way, contributes to coke removal $[40,41]$. Additionally, lanthanum is known to stabilize metal particles and oxides by preventing sintering $[42,43]$.

\subsubsection{Pre-reforming of heavier components: naphtha}

In the beginning of last century, naphtha was the most economic feedstock in Europe, in contrast to the natural gas available in United States. Steam reforming of naphtha, thus, became the major industrial route for hydrogen production.

$$
\mathrm{C}_{\mathrm{n}} \mathrm{H}_{\mathrm{m}}+\mathrm{nH}_{2} \mathrm{O} \rightarrow \mathrm{nCO}+\left(\mathrm{n}+\frac{m}{2}\right) \mathrm{H}_{2} \quad, \mathrm{n}>1 \quad \Delta H_{298}^{0}>0 \mathrm{~kJ} \cdot \mathrm{mol}^{-1}
$$


In this case, the temperatures required for the process are lower than those applied in steam reforming of methane. This can be explained by the fact that the bond dissociation energies of higher hydrocarbons are lower than those of methane and therefore easier to activate. For the same reason formation of carbon deposits is more severe compared to methane and is one of the main issues. Multiple studies have been performed to elucidate the mechanism of coke formation/growth and to circumvent this bottleneck $[44,45]$. A separate catalyst (pre-reforming) is used for the process [46].

\subsubsection{Reaction mechanism for steam reforming of methane and higher hydrocarbons}

A bifunctional mechanism (Langmuir-Hinshelwood) has been proposed for the steam reforming of methane over supported Ni catalysts [26, 47]. It is commonly agreed that decomposition of methane on nickel surface via $\mathrm{C}$-H rupture is the first step of the steam reforming of methane. Subsequently, the carbonaceous species $\left(\mathrm{CH}_{\mathrm{x}}, 1 \leq \mathrm{x} \leq 3\right)$ formed on the surface react with steam or surface oxygen species [30] to produce syngas. Similarly, the conversion of higher hydrocarbons takes place by irreversible adsorption to the nickel surface on a dual site, subsequent breakage of terminal C-C bonds one by one until, eventually, the hydrocarbon is converted into $\mathrm{C}_{1}$ components [27]. As for water activation, Rostrup-Nielsen [26] suggested that water is adsorbed and activated on the support, hydroxylating the surface and the formed $\mathrm{OH}$ groups react with the resulting $\mathrm{C}_{1}$ species to produce syngas. Additionally, it has been reported [26] that nickel surfaces are able to dissociate water via nickel oxidation (Eq. 1.3). Thus, the use of nickel based catalysts provides additional active sites for water activation. This allows for higher steam reforming activities.

$$
\mathrm{Ni}+\mathrm{H}_{2} \mathrm{O} \rightleftarrows \mathrm{NiO}+\mathrm{H}_{2} \quad \Delta H_{298}^{0}=2.12 \mathrm{~kJ} \cdot \mathrm{mol}^{-1}
$$

Similar to the steam reforming of methane, both metal and support participate in the steam reforming of higher hydrocarbons, hence, involving a bi-functional mechanism. Such mechanism was also proposed by Praharso et al. [48] to describe the steam reforming of iso-octane over a nickel-based catalyst. 


\subsubsection{Water-gas shift reaction}

The main objective of the WGS reaction when coupled with hydrocarbons reforming is to maximize hydrogen production or adjust the $\mathrm{H}_{2} / \mathrm{CO}$ ratio according to the end application $[27,48]$

$$
\mathrm{CO}+\mathrm{H}_{2} \mathrm{O} \rightleftarrows \mathrm{CO}_{2}+\mathrm{H}_{2} \quad \Delta H_{298}^{0}=-41.1 \mathrm{~kJ} \cdot \mathrm{mol}^{-1}
$$

It is a well known reversible exothermic reaction. Therefore, CO conversions are favored at low temperatures. In order to overcome this thermodynamic limitation and thus increase conversions, the WGS is carried out in multiple stages. The first step (high-temperature shift) which operates at $300-450{ }^{\circ} \mathrm{C}$ is catalyzed by $\mathrm{Fe}-\mathrm{Cr}$ based catalysts. This catalyst is resistant to poisons present in syngas, such as chlorine and sulfur and it acts as a poison trap. Additionally, this catalyst is resistant to adiabatic temperature increase. However, $\mathrm{Fe}-\mathrm{Cr}$ catalysts have low activity and thus, high temperatures are required in this step. Thermodynamics dictates that the equilibrium towards hydrogen production is unfavorable at high temperatures and thus high temperature shift results in low $\mathrm{CO}$ conversions. In order to reach high conversions a second step (low-temperature shift) which operates at lower temperatures $\left(180-230^{\circ} \mathrm{C}\right)$ over a very active catalyst $(\mathrm{Cu}-\mathrm{Zn}$ based catalyst) is used [49]. The sensitivity of this catalyst to sintering and sulfur and chlorine poisoning does not make suitable this catalyst to be used in the high temperature shift.

Two stages approach is not desirable for mobile applications because of its technical complexity. In this respect, extensive research is reported on the design of robust and active catalysts which can be applied in one single stage WGS reactor. Supported precious metal catalysts show promise [50-52].

\subsubsection{Coal gasification}

Coal is a relatively cheap and readily available source of energy. The first companies to convert coal to combustible gas through gasification were chartered in 1912. During the 1930's, the first commercial coal gasification plants were constructed. In the 1950's, gasification started to be applied for hydrogen production. Currently, gasification is a commercially proven mature technology with about $40 \mathrm{GW}$ total syngas production capacity around the world [53]. The process is carried 
out non-catalytically at high temperatures $\left(925-1125^{\circ} \mathrm{C}\right)$ and moderate pressures (5-10 bar) [54]. In contrast, catalytic coal gasification such as the Exxon Catalytic Coal Gasification process, where potassium-based catalysts are used, never reached commercialization. The reasons for that are (i) new gas discovery (cheaper source), (ii) approximately $1 / 3$ of the catalyst is lost due to formation of alumino-silicates (recovery is not possible) and (iii) economics of the process is unfavorable.

$$
\mathrm{C}+\mathrm{H}_{2} \mathrm{O} \rightarrow \mathrm{CO}+\mathrm{H}_{2} \quad \Delta H_{298}^{0}=+135.7 \mathrm{~kJ} \cdot \mathrm{mol}^{-1}
$$

During coal gasification, other reactions take place such as water-gas shift, methanation, reforming and partial oxidation. Some of these reactions result in massive amounts of $\mathrm{CO}_{2}$ which are released to the atmosphere, contributing negatively to the greenhouse effect. Thus, solid carbon-containing sources which are $\mathrm{CO}_{2}$ neutral are potential feedstocks to substitute coal.

Renewable biomass is an attractive alternative to coal for hydrogen production through gasification. It is predicted that environmental, technical and economical advantages could be acquired by the use of biomass in the existing coal gasification systems [55]. Similar to coal, biomass contains few impurities such as sulphur which complicate the biomass gasification process in terms of catalyst stability. Another similarity between coal and biomass is the formation of ashes inherent to gasification, which results in slagging, agglomeration and depositon. Additional information on biomass conversion will be further addressed below in this chapter.

To summarize, it can be concluded that no commercial catalyst is yet available for coal gasification. However the experience and infrastructure can be used for biomass.

\subsection{Biomass}

\subsubsection{Biomass conversion technologies}

Environmental friendly energy is a major goal in our society. Lignocellulosic biomass has recently drawn attention as a renewable hydrogen source, i.e. with no net contribution to $\mathrm{CO}_{2}$ emissions. Biomass presents advantages over other sustainable sources such as solar, hydro, wind and geothermal. First of all, biomass is the only 
renewable source of carbon, hydrogen and oxygen and therefore is suitable for the production of conventional chemicals and fuels. Secondly, biomass or processed products can be easily stored as compared to other sources [56]. However biomass as such is ineffective, owing to its low energy density. Liquefaction of biomass to produce liquid fuels is an efficient technology to improve biomass energy density $[55,57]$.

Two technologies for hydrogen production have been explored in recent years: direct steam gasification of biomass and catalytic steam reforming of the bio-liquids, namely pyrolysis oils, derived from fast pyrolysis of biomass [15, 58]. Gasification of biomass is not the preferred option. The greatest barrier lies in the logistics. This process requires large quantities of biomass to run the plant effectively due to its volumetric energy density. Therefore, there must be material close enough to the plant to be transported economically. On the contrary, pyrolysis oil is a liquid. This makes it a convenient feedstock for storage, transport and processing as compared to the bulk biomass. Additionally, pyrolysis oil has a higher energy density and this makes transport more economically attractive, especially over long distances. Pyrolysis oils are produced when biomass is heated to typically $500{ }^{\circ} \mathrm{C}$ in short residence times and in the absence of air. Char and gas are by-products. High yields of liquid products (up to $70-80 \%$ ) can be achieved based on the dry feed $[56,58,59]$.

The most promising route to generate hydrogen from pyrolysis oil is via catalytic steam reforming followed by water-gas shift reaction, as these reactions steps give the highest hydrogen yield (Eq. 1.6)

$$
\mathrm{C}_{\mathrm{n}} \mathrm{H}_{\mathrm{m}} \mathrm{O}_{\mathrm{z}}+(2 \mathrm{n}-\mathrm{k}) \mathrm{H}_{2} \mathrm{O} \rightarrow \mathrm{nCO}_{2}+\left(2 n+\frac{m}{2}-k\right) \mathrm{H}_{2} \quad \Delta H_{298}^{0}>0 \mathrm{~kJ} \cdot \mathrm{mol}^{-1}
$$

Pyrolysis oils can be converted directly as such or using specific fractions. In the former case, large amounts of coke are formed during the reforming process, resulting in catalyst deactivation. Additionally, direct feeding of the pyrolysis oil as such is not easy, since it is very unstable above $80-90{ }^{\circ} \mathrm{C}$ due to polymerization reactions. Consequently, pyrolysis oil evaporation results in carbonaceous solid residues (char). Deposition of char on the catalytic bed results in reactor clogging and catalyst deactivation. Furthermore, the efficiency of the steam reforming process 
decreases if this char is not further converted. Due to these significant bottlenecks, only few studies on the steam reforming of pyrolysis oil are available in literature, mostly applied on nobel metal supported catalysts $[15,16]$. In this respect, Rioche et al. [16] reported successful results in terms of activity and stability for a limited period of time (ca. $2 \mathrm{~h}$ ) using a ceria-zirconia supported Pt based catalyst $\left(1 \mathrm{wt} \% \mathrm{Pt} / \mathrm{CeZrO}_{2}\right)$ and relatively high steam to carbon ratios (11:1). However, the authors reported that, under harsher reaction conditions in terms of carbon deposition (steam to carbon of 5) and longer times on stream, a slow decrease in hydrogen production occurred. It was concluded that improvement in the preparation of the $\mathrm{CeZrO}_{2}$ support could minimize the catalyst aging. Domine et al. [15] have shown recently that steam reforming of pyrolysis oil can be performed over $\mathrm{Pt}$ and $\mathrm{Rh}$ monolithic catalysts (1wt.\% $\mathrm{Pt} / \mathrm{Ce}_{0.5} \mathrm{Zr}_{0.5} \mathrm{O}_{2}$ and $1.04 \mathrm{wt} . \% \mathrm{Rh} / \mathrm{Ce}_{0.5} \mathrm{Zr}_{0.5} \mathrm{O}_{2}$ supported on cordierite monoliths). Complete pyrolysis oil conversion resulting mainly in $\mathrm{H}_{2}$ and $\mathrm{CO}_{2}$ was achieved when the reaction was carried out in the temperature range of $700-780{ }^{\circ} \mathrm{C}$ and a steam to carbon ratio of 10 over both catalysts. However platinum-based catalysts were more active towards hydrogen production than rhodium-based catalysts. They attributed this fact to the higher water-gas shift activity of $\mathrm{Pt}$ as compared to $\mathrm{Rh}$. Catalyst stability was reported to be excellent during the tested period $(1.5 \mathrm{~h})$, despite coke deposition and substantial sintering of the ceria-zirconia support occurred. These results were expected, as the system was essentially controlled by thermodynamics. Alternatively, van Rossum et al. [56] studied catalytic steam reforming of pyrolysis oil over commercial Ni-based catalysts. The authors reported very promising results applying a novel reactor concept which consists of a reactor with two catalyst beds in series. The first part of the reactor, composed by a fluidized bed containing a good heat transfer material (sand), enables improvement of the pyrolysis oil evaporation. The second part of the reactor consists of a fixed catalytic bed to convert the vapours released during evaporation to syngas. Recently [60], the whole pyrolysis oil has also been successfully steam reformed over nickel supported on attrition resistant materials in a single fluidized bed. However, improvements to further decrease catalyst losses are required.

It is well established $[61,62]$ that addition of water to the pyrolysis oil generates two fractions: non-aqueous and aqueous. The former can be used to produce 
chemicals and the latter can be steam reformed. That reduces the limitations encountered in the steam reforming of the entire pyrolysis oil in terms of operation. Thus, studies dealing with the steam reforming of the aqueous phase fraction are more frequent [58, 61, 63, 64]. However, coke formation, which results in catalyst deactivation, is still a major challenge. The ability to diminish the surface reactions resulting in carbonaceous deposits is key to achieve stable catalysts. Addition of promoters to the catalysts is reported to be successful to minimize coke accumulation on the catalyst surface. More specifically, Garcia and co-workers [58] observed improved catalytic performance of magnesium-based and lanthanum-based catalysts as compared to their non-promoted analogous catalysts during aqueous phase steam reforming. They reported that these additives enhanced steam adsorption that facilitates the gasification of surface carbon. The use of nobel metals catalysts instead of the conventional nickel supported catalysts also allows for minimization of coke deposition. Surface reactions resulting in carbonaceous species are reduced and in this way, homogeneous coke produced via polymerization of pyrolysis oil becomes the major coke formation route [63].

\subsubsection{Steam reforming of components of pyrolysis oil}

As mentioned earlier, pyrolysis oils are multi-component mixtures of oxygenates derived from biomass carbohydrates and lignin. Therefore, structure of pyrolysis oils is extremely complex. It is here appropriate to stress that pyrolysis oil composition depends on biomass feedstock, as shown in Table 1.1. In order to give insight in reaction mechanisms of steam reforming of pyrolysis oil for efficient catalyst design, model representative compounds are often studied. During the last decade, steam reforming of pyrolysis oil model components has been persistently studied. The most studied oxygenates in the beginning were small alcohol molecules such as methanol and ethanol due to its simplicity. Methanol, for instance, can be readily steam reformed at low temperatures $\left(200-300{ }^{\circ} \mathrm{C}\right)$, commonly over copper-based catalysts [65]. Despite the large number of studies available in literature on the steam reforming of simple alcohols, Table 1.1 shows that this type of components are only present in pyrolysis oil in small amounts and therefore are not representative. In contrast, acetic acid and its isomer hydroxyacetaldehyde are 
Table 1.1. Composition of pyrolytic oils derived from different feedstocks (adopted from [60])

\begin{tabular}{lccc}
\hline \multirow{2}{*}{ Product } & \multicolumn{3}{c}{ Fluidized bed } \\
\cline { 2 - 4 } acetic acid & 5.4 & 5.8 & 3.9 \\
formic acid & 3.1 & 6.4 & 7.2 \\
hydroxyacetaldehyde & 10.0 & 7.6 & 7.7 \\
glyoxal & 2.2 & 1.8 & 2.5 \\
acetol & 1.4 & 1.2 & 1.2 \\
ethylene glycol & 1.1 & 0.6 & 0.9 \\
fructose & 1.3 & 1.5 & 2.3 \\
glucose & 0.4 & 0.6 & 1.0 \\
cellobiosan & 1.3 & 1.6 & 2.5 \\
pyrolytic lignin & 16.2 & 20.9 & 20.6 \\
oil & 65.8 & 67.9 & 66.5 \\
water & 12.2 & 9.8 & 11.6 \\
char & 7.7 & 13.7 & 12.2 \\
gas & 10.8 & 9.8 & 7.8 \\
\hline
\end{tabular}

major compounds of pyrolysis oil (up to $15 \%$ ). Accordingly, in the last few years extensive work has been carried out on acetic acid [14, 16, 66-71]. Temperatures as low as $450^{\circ} \mathrm{C}$ are sufficient to fully steam reform acetic acid over commercial nickel catalysts $[66,67]$. Unfortunately, significant amounts of coke are produced over the nickel-based catalysts, similar to the steam reforming of pyrolysis oil or its fractions. Also in this case, it has been stated in literature that addition of promoters has a beneficial effect on the catalytic performance in terms of catalyst stability $[14,72]$. More specifically, Verykios and co-workers [72] revealed that the presence of lanthanum as a promoter extents nickel catalyst life remarkably. This improvement was attributed to the presence of a surface generated lanthanum oxycarbonate, which enhances coke gasification and thus minimizes coke accumulation. As demonstrated in the case of steam reforming of pyrolysis oil, coking can be greatly suppressed with the use of nobel metal catalysts $[15,16,73]$. 
One of the main issues in biomass gasification is formation of tars during the process [74-76]. These compounds, which basically consist of phenolic compounds, cause serious hazard to the equipment downstream due to their condensation at low temperatures, resulting in a reduction in performance and in increasing maintenance requirements. Their elimination is therefore highly desirable. Tar reforming is one attractive way to reduce the presence of tars during biomass gasification [74, 77, 78]. Commercial Ni-based catalysts for naphtha reforming have been found [79] to be very active and stable for real tar removal at relatively high temperatures $\left(780-830^{\circ} \mathrm{C}\right)$.

Steam reforming of phenol towards hydrogen production has also been investigated, as phenol is a representative model compound of tars [76]. However, only a limited number of research works are available in literature [66-68]. Nobel metals ( $\mathrm{Rh}$ and $\mathrm{Fe}$ ) supported on red-ox oxides are reported to have good catalytic performances. Interestingly, a recent study [80], has shown that natural calcite materials also possess good catalytic activity at high temperatures $\left(>650^{\circ} \mathrm{C}\right)$.

\subsubsection{Reaction mechanism for steam reforming of pyrolysis oil model compounds}

The mechanistic aspects of steam reforming of oxygenates present in pyrolysis oil are still unclear. However, most of the results reported in literature suggest, similar to hydrocarbons, a bifunctional mechanism, where both metal and support participate in the reaction $[69,75,81]$. As mentioned earlier, acetic acid has been extensively studied as a model compound of pyrolysis oil. A detailed mechanistic study on the steam reforming of acetic acid over $\mathrm{Pt} / \mathrm{ZrO}_{2}$ was performed by Takanabe et al. $[69,82]$. The authors proposed that acetic acid dissociatively adsorbs on the Pt sites, leaving dehydrogenated type specie, $\mathrm{CH}_{\mathrm{x}}(1 \leq \mathrm{x} \leq 3)$, whereas water is adsorbed and activated forming hydroxyl groups on the support, as evidenced by IR measurements [69]. The dehydrogenated carbonaceous species $\left(\mathrm{CH}_{\mathrm{x}}\right)$ are then being steam reformed by the hydroxyl groups formed on the support, leading to syngas production. Hydrogen also arises from the decomposition of acetic acid on Pt. It was further proposed that the active sites are located at the boundary between Pt particles and $\mathrm{ZrO}_{2}$, based on the following observations: (i) hydrogen formation rates strongly correlate with the number of $\mathrm{Pt}$ atoms on the perimeter of $\mathrm{Pt}$ particles, i.e. on the metal-support boundary, (ii) $\mathrm{Pt} / \mathrm{ZrO}_{2}$ catalysts with different particle size give the 
same intrinsic activity per $\mathrm{Pt}$ on the perimeter, i.e. properties of $\mathrm{Pt}$ atoms on the perimeter do not depend on particle size and (iii) the support influences the intrinsic activity per Pt periphery site. The basic concept of bifunctionality has been suggested to also occur for the steam reforming of other oxygenates over Fe-based catalysts [75].

Steam reforming of acetic acid has also been widely explored over nickel-based catalysts [72, 83, 84]. However, most of the research has been focused on catalyst activity and stability and very little work has addressed the mechanistic aspects involved in the reaction [66]. Wang et al. [66] proposed a mechanism which involves adsorbed " $\mathrm{CH}_{3}$ " species derived from acetic acid and their subsequent conversion on the catalyst surface. The authors also emphasized that the main difference in steam reforming mechanism between hydrocarbons and oxygenates is the fact that oxygenates present in pyrolysis oil are thermally unstable. At the operating temperatures of a steam reformer these oxygenates undergo homogeneous thermal decomposition and this reaction compete with the steam reforming reaction to produce hydrogen.

\subsection{Scope and outline of this thesis}

The main objective of this thesis is to understand and elucidate the reaction and deactivation mechanisms involved in the steam reforming of flash pyrolysis based pyrolysis oil in order to design an active and stable catalyst for this process. Pyrolysis oil consists of a large number and variety of oxygenated compounds. Due to this complexity, it is too difficult to draw relations between structure, properties and reaction mechanism. The choice of simple representative molecules present in pyrolysis oil simplifies these structure-properties-mechanism relations. Thus, the approach is this thesis is to develop a catalyst based on these model components studies and translate the obtained results to the steam reforming of pyrolysis oil. The first part of this dissertation (Chapters 2, 3 and 4) addresses acetic acid as a model compound of light oxygenates. Chapter 2 consists of a detailed isotopic study of acetic acid activation on $\mathrm{Pt} / \mathrm{C}$. New findings validating the bifunctional mechanism for the steam reforming of acetic acid suggested in previous investigations are reported. This chapter is adapted from the following publication: 
B. Matas Güell, I. Babich, K. Seshan and L. Lefferts, Journal of Catalysis 257 (2008) 229-231

One of the main issues in the production of hydrogen during steam reforming is the development of a stable catalyst. Formation of carbonaceous species during reaction results in catalyst deactivation and thus poor catalyst stability. The following two chapters describe two approaches to improve the catalytic stability of a $\mathrm{Pt} / \mathrm{ZrO}_{2}$ catalyst previously investigated. In Chapter 3, we explored the influence of small amounts of oxygen in the steam reforming feed as well as the use of a catalyst support with red-ox properties. For this purpose, we compared the catalytic performance of $\mathrm{Pt} / \mathrm{ZrO}_{2}$ and $\mathrm{Pt} / \mathrm{CeO}_{2}$ in the presence and absence of oxygen. Therein, the causes for catalyst deactivation were also investigated. This chapter is based on the following paper:

B. Matas Güell, I. M. Torres da Silva, K. Seshan and L. Lefferts, Applied Catalysis B: Environmental 88 (2009) 59-65

Chapter 4 addresses the enhancement of water activation by the presence of nickel instead of platinum $\left(\mathrm{Ni} / \mathrm{ZrO}_{2}\right)$, as an alternative approach to improve catalyst stability. Furthermore, the role of lanthanum and potassium promoters on the catalytic performance is discussed. These aspects are published in the following manuscript:

B. Matas Güell, I. Babich, K. P. Nichols, J. G. E. Gardeniers, L. Lefferts and K. Seshan, Applied Catalysis B: Environmental 90 (2009) 38-44

The second part of this thesis focuses on the steam reforming of phenol as a representative component of heavier oxygenates. Hence, this section of the thesis deals with a model component which presents higher complexity than acetic acid and is therefore closer to the real structure of pyrolysis oil. Modifications on the previous developed catalysts for steam reforming of acetic acid in order to exhibit good catalytic performance during steam reforming of phenol are reported. Design of a novel nickel-ceria-zirconia based catalyst is elaborated. These viewpoints are comprehended in Chapter 5. This chapter is discussed in the following manuscript: 
B. Matas Güell, I.V. Babich, L. Lefferts and K. Seshan, Applied Catalysis (to be submitted)

The last section of this work addresses two issues related to gasification of pyrolysis oil. First of all, the problem associated with homogeneous coke (char) formation and promising catalytic solutions (Chapters 6 and 7) is discussed. The second part shows gasification of pyrolysis oil as such. Chapter 6 reports on char formation in absence of catalyst during pyrolysis oil evaporation. Char reactivity during non-catalytic steam gasification is examined. The influence of temperature and nature of pyrolysis oil on both char formation and gasification is elucidated. This chapter is adapted from the following manuscript:

G. van Rossum, B. Matas Güell, R.P.B. Ramachandran, K. Seshan, L. Lefferts, W.P.Mvan Swaaij, S.R.A. Kersten, AIChE (submitted 2009)

In Chapter 7, char formation and gasification in the presence of a ceria-zirconia based catalyst is described. A detailed comparison between catalytic and non-catalytic gasification rates is reported. Moreover, the role of the catalyst is established on the basis of BET, XPS and SEM characterization. This chapter is discussed in the subsequent publication:

B. Matas Güell, G. van Rossum, W.P.M. van Swaaij, S.R.A. Kersten, L. Lefferts, K. Seshan, Fuels (submitted 2009) 


\section{References}

[1] M.J. Castaldi, and J.P. Dooher, International Journal of Hydrogen Energy 32 (2007) 4170-4179.

[2] E.I.A. (EIA). 2008. International energy outlook 2008.

[3] J. Sheffield, Nuclear Instruments and Methods in Physics Research Section A: Accelerators, Spectrometers, Detectors and Associated Equipment 464 (2001) 33-37.

[4] R.C. Saxena, D.K. Adhikari, and H.B. Goyal, Renewable and Sustainable Energy Reviews 13 (2009) 167-178.

[5] S. Shafiee, and E. Topal, Energy Policy 37 (2009) 181-189.

[6] T.N. Veziroglu, and S. Sahin, Energy Conversion and Management 49 (2008) 1820-1831.

[7] H.H. Khoo, and R.B.H. Tan, Energy Fuels 20 (2006) 1914-1924.

[8] A.M. Omer, Renewable and Sustainable Energy Reviews 12 (2008) 2265-2300.

[9] W.P. Nel, and C.J. Cooper, Energy Policy 37 (2009) 166-180.

[10] M. Balat, Energy Sources, Part A: Recovery, Utilization, and Environmental Effects 30 (2008) 552 - 564.

[11] R.M. Navarro, M.A. Pena, and J.L.G. Fierro, Chem. Rev. 107 (2007) 3952-3991.

[12] W.E. Winsche, K.C. Hoffman, and F.J. Salzano, Science 180 (1973) 1325-1332.

[13] http://hydrogen.pnl.gov/cocoon/morf/hydrogen/article/706

[14] B.M. Güell, I.M.T. da Silva, K. Seshan, and L. Lefferts, Applied Catalysis B: Environmental 88 (2009) 59-65.

[15] M.E. Domine, E.E. Iojoiu, T. Davidian, N. Guilhaume, and C. Mirodatos, Catalysis Today 133-135 (2008) 565-573.

[16] C. Rioche, S. Kulkarni, F.C. Meunier, J.P. Breen, and R. Burch, Applied Catalysis B: Environmental 61 (2005) 130-139.

[17] http://www.freedoniagroup.com

[18] J. Xuan, M.K.H. Leung, D.Y.C. Leung, and M. Ni, Renewable and Sustainable Energy Reviews 13 (2009) 1301-1313.

[19] M. Schwoon, Simulation Modelling Practice and Theory 16 (2008) 1463-1476.

[20] L. Janssen, Journal of Applied Electrochemistry 37 (2007) 1383-1387.

[21] R. von Helmolt, and U. Eberle, Journal of Power Sources 165 (2007) 833-843. 
[22] J.R. Rostrup-Nielsen, and T. Rostrup-Nielsen, CATTECH 6 (2002) 150-159.

[23] I.V. Babich, and J.A. Moulijn, Fuel 82 (2003) 607-631.

[24] T. Zhang, and M.D. Amiridis, Applied Catalysis A: General 167 (1998) 161-172.

[25] J.R. Rostrup-Nielsen, Catalysis: Science and Technology 5 (1984) 1-117.

[26] F. Joensen, and J.R. Rostrup-Nielsen, Journal of Power Sources 105 (2002) 195-201.

[27] D. Moon, Catalysis Surveys from Asia 12 (2008) 188-202.

[28] P.W. Atkins, Physical Chemistry, London, 2006.

[29] Y. Matsumura, and T. Nakamori, Applied Catalysis A: General 258 (2004) 107-114.

[30] K. Urasaki, Y. Sekine, S. Kawabe, E. Kikuchi, and M. Matsukata, Applied Catalysis A: General 286 (2005) 23-29.

[31] N. Martín, M. Viniegra, R. Zarate, G. Espinosa, and N. Batina, Catalysis Today 107-108 (2005) 719-725.

[32] D.L. Trimm, Catalysis Today 49 (1999) 3-10.

[33] F. Arena, F. Frusteri, and A. Parmaliana, Applied Catalysis A: General 187 (1999) 127-140.

[34] R. Martinez, E. Romero, C. Guimon, and R. Bilbao, Applied Catalysis A: General 274 (2004) 139-149.

[35] U. Olsbye, O. Moen, A. Slagtern, and I.M. Dahl, Applied Catalysis A: General 228 (2002) 289-303.

[36] A. Gołębiowski, K. Stołecki, U. Prokop, A. Kuśmierowska, T. Borowiecki, A. Denis, and C. Sikorska, Reaction Kinetics and Catalysis Letters 82 (2004) 179-189.

[37] J.W. Snoeck, G.F. Froment, and M. Fowles, Industrial \& Engineering Chemistry Research. 41 (2002) 3548-3556.

[38] M.A. Henderson, Surface Science Reports 46 (2002) 1-308.

[39] Z. Zhang, and X.E. Verykios, Applied Catalysis A: General 138 (1996) 109-133.

[40] X.E. Verykios, International Journal of Hydrogen Energy 28 (2003) 1045-1063.

[41] N.S. Figoli, P.C. Largentiere, A. Arcoya, and X.L. Seoane, Journal of Catalysis 155 (1995) 95-105.

[42] H. Schaper, E.B.M. Doesburg, and L.L. Van Reijen, Applied Catalysis 7 (1983) 211-220.

[43] E. Nikolla, J.W. Schwank, and S. Linic, Catalysis Today 136 (2008) 243-248. 
[44] E. Nikolla, A. Holewinski, J. Schwank, and S. Linic, Journal of the American Chemical Society 128 (2006) 11354-11355.

[45] H. Shu-Ren, International Journal of Hydrogen Energy 23 (1998) 315-319.

[46] J.R.H. Ross, M.C.F. Steel, and A. Zeini-Isfahani, Journal of Catalysis 52 (1978) 280-290.

[47] Praharso, A.A. Adesina, D.L. Trimm, and N.W. Cant, Chemical Engineering Journal 99 (2004) 131-136.

[48] W. Ruettinger, O. Ilinich, and R.J. Farrauto, Journal of Power Sources 118 (2003) 61-65.

[49] K.G. Azzam, I.V. Babich, K. Seshan, and L. Lefferts, Applied Catalysis B: Environmental 80 (2008) 129-140.

[50] G. Jacobs, L. Williams, U. Graham, D. Sparks, and B.H. Davis, Journal of Physical Chemistry B 107 (2003) 10398-10404.

[51] T. Tabakova, V. Idakiev, D. Andreeva, and I. Mitov, Applied Catalysis A: General 202 (2000) 91-97.

[52] R.M. Navarro, M.A. Pena, and J.L.G. Fierro, Chemical Reviews 107 (2007) 3952-3991.

[53] Y. Shang Jung, and E.E. Wolf, Fuel 62 (1983) 738-741.

[54] M. Yilgin, and D. Pehlivan, Applied Energy 86 (2009) 1179-1186.

[55] G. van Rossum, S.R.A. Kersten, and W.P.M. van Swaaij, Industrial \& Engineering Chemistry Research 46 (2007) 3959-3967.

[56] V.R. Rustamov, K.M. Abdullayev, and E.A. Samedov, Energy Conversion and Management 39 (1998) 869-875.

[57] L. Garcia, R. French, S. Czernik, and E. Chornet, Applied Catalysis A: General 201 (2000) 225-239.

[58] S. Czernik, and A.V. Bridgwater, Energy \& Fuels 18 (2004) 590-598.

[59] S. Czernik, R. Evans, and R. French, Catalysis Today 129 (2007) 265-268.

[60] P.N. Kechagiopoulos, S.S. Voutetakis, A.A. Lemonidou, and I.A. Vasalos, Energy \& Fuels 20 (2006) 2155-2163.

[61] C.A. Mullen, and A.A. Boateng, Energy \& Fuels 22 (2008) 2104-2109.

[62] A.C. Basagiannis, and X.E. Verykios, Catalysis Today 127 (2007) 256-264.

[63] D. Wang, S. Czernik, and E. Chornet, Energy \& Fuels 12 (1998) 19-24.

[64] D. Wang, D. Montané, and E. Chornet, Applied Catalysis A: General 143 (1996) 245-270.

[65] D. Wang, S. Czernik, D. Montane, M. Mann, and E. Chornet, Industrial \& Engineering Chemistry Research 36 (1997) 1507-1518. 
[66] K. Takanabe, K. Aika, K. Seshan, and L. Lefferts, Journal of Catalysis 227 (2004) 101-108.

[67] K. Takanabe, K.-i. Aika, K. Inazu, T. Baba, K. Seshan, and L. Lefferts, Journal of Catalysis 243 (2006) 263-269.

[68] A.C. Basagiannis, and X.E. Verykios, Applied Catalysis A: General 308 (2006) 182-193.

[69] J.R. Galdamez, L. Garcia, and R. Bilbao, Energy Fuels 19 (2005) 1133-1142.

[70] A.C. Basagiannis, and X.E. Verykios, Applied Catalysis A: General 308 (2006) 182-193.

[71] E.E. Iojoiu, M.E. Domine, T. Davidian, N. Guilhaume, and C. Mirodatos, Applied Catalysis A: General 323 (2007) 147-161.

[72] K. Sato, and K. Fujimoto, Catalysis Communications 8 (2007) 1697-1701.

[73] K. Polychronopoulou, A. Bakandritsos, V. Tzitzios, J.L.G. Fierro, and A.M. Efstathiou, Journal of Catalysis 241 (2006) 132-148.

[74] K. Polychronopoulou, J.L.G. Fierro, and A.M. Efstathiou, Journal of Catalysis 228 (2004) 417-432.

[75] D.A. Constantinou, and A.M. Efstathiou, Catalysis Today 143 (2009) 17-24.

[76] S. Czernik, R. French, C. Feik, and E. Chornet, Industrial \& Engineering Chemistry Research 41 (2002) 4209-4215.

[77] K. Takanabe, K.-I. Aika, K. Seshan, and L. Lefferts, Topics in Catalysis 49 (2008) 68-72.

[78] D. Wang, D. Montane, and E. Chornet, Applied Catalysis A: General 143 (1996) 245-270.

[79] X. Hu, and G. Lu, Journal of Molecular Catalysis A: Chemical 261 (2007) 43-48. 



\section{Chapter 2}

\section{Mechanism of acetic acid activation on supported-platinum catalysts for steam reforming}

The activation of acetic acid during steam reforming reactions over Pt-based catalysts has been probed by decomposing $\mathrm{CH}_{3} \mathrm{COOD}$ over Pt/C. The product mixture contained $\mathrm{CO}_{2}, \mathrm{CH}_{4}$ and its $\mathrm{D}$ - analogs $\left(\mathrm{CH}_{4-x} \mathrm{D}_{x}, \mathrm{O} \leq x \leq 4\right), \mathrm{H}_{2}, \mathrm{HD}$ and $\mathrm{D}_{2}$. $\mathrm{CO}_{2}, \mathrm{CH}_{3} \mathrm{D}$ and $\mathrm{D}_{2}$ are typically primary desorption products whereas the rest originate from hydrogen redistribution reactions and $H-D$ exchange. The bifunctional mechanistic pathways suggested earlier [1, 2] for the steam reforming of acetic acid over $\mathrm{Pt} / \mathrm{ZrO}_{2}$ are substantiated. 



\subsection{Introduction}

Currently, sustainable routes to hydrogen, a future energy carrier, are of much interest. Steam reforming of biomass is one such option; however, development of an efficient and stable catalyst is a bottleneck [1-4]. Knowledge of the reaction mechanism is an essential point for the catalyst improvement. In this context, we proposed in previous studies [1,2], on biomass-based oxygenates, that a bifunctional mechanism, where both $\mathrm{Pt}$ and support participate in the catalytic reaction, is involved for the steam reforming of acetic acid (AcOH) over $\mathrm{Pt} / \mathrm{ZrO}_{2}$ (see Fig. 2.1).

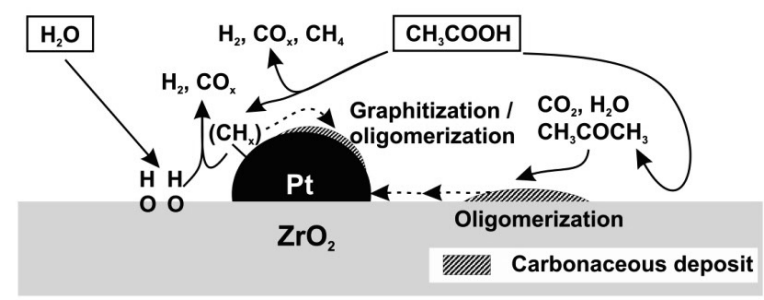

Fig. 2.1. Proposed mechanism for the steam reforming of acetic acid over a $\mathrm{Pt} / \mathrm{ZrO}_{2}$ catalyst. Adapted from [2].

Pulses of $\mathrm{AcOH} / \mathrm{H}_{2} \mathrm{O}$ over $\mathrm{ZrO}_{2}$ resulted in high amounts of acetone via condensation of $\mathrm{AcOH}$ molecules and subsequent formation of carbonaceous deposits originating from acetone. These results indicate that $\mathrm{ZrO}_{2}$ catalyses oligomerization reactions. Fortunately, this is not the only catalytic route over the support. IR studies revealed that $\mathrm{ZrO}_{2}$ activates water to form supplementary reactive hydroxyl groups, which can participate in the steam reforming and water-gas shift reactions.

On the other hand, pulses of $\mathrm{AcOH} / \mathrm{H}_{2} \mathrm{O}$ over Pt black (no support oxide) led to typical steam reforming products, suggesting that $\mathrm{Pt}$ is essential for the occurrence of steam reforming. Unlike metals such as $\mathrm{Ni}$ [5], Re [6] and Fe [7], dissociation of water on Pt is improbable at the reaction conditions used in this study [8,9]. Thus, it was concluded that the steam reforming activity on Pt black was due to the presence of alkali impurities which are known to catalyze steam gasification.

In previous investigations it was suggested that $\mathrm{AcOH}$ decomposes on $\mathrm{Pt}$ forming $\mathrm{CH}_{\mathrm{x}},(1 \leq \mathrm{x} \leq 3)$ type surface specie [1, 2] (see Fig. 2.1). Hydrogen formation rates correlated strongly with the number of $\mathrm{Pt}$ atoms in the close proximity of the 
support. Additionally, regeneration of $\mathrm{Pt} / \mathrm{ZrO}_{2}$ required combustion of carbon residues located at the boundary between $\mathrm{Pt}$ and $\mathrm{ZrO}_{2}$. These facts suggested that these $\mathrm{CH}_{\mathrm{x}}$ specie on Pt react with hydroxyl groups at the periphery between $\mathrm{Pt}$ and $\mathrm{ZrO}_{2}$ forming hydrogen and carbon oxides. However, it was not possible to provide experimental evidence for the existence of intermediate surface $\mathrm{CH}_{\mathrm{x}}$ specie under reaction conditions because of their high reactivity with $\mathrm{OH}$ groups. In order to establish the formation of such $\mathrm{CH}_{\mathrm{x}}$ specie on $\mathrm{Pt}$ it is essential to (i) carry out experiments preventing presence of hydroxyl groups, e.g., using a hydrophobic support such as graphite and (ii) use deuterated acetic acid which allows us to interpret redistribution reactions of intermediate surface hydrocarbon species.

In this study, we report on the activation of $\mathrm{CH}_{3} \mathrm{COOD}$ over $\mathrm{Pt} / \mathrm{C}$ (graphite) catalysts. Use of graphite allows us to disperse Pt and to provide measurable activity under our experimental conditions, in comparison to pure Pt. It is well established [10] that activation of hydrocarbons is facile over Pt, independent of the support [1]. It has been shown by Zaera [11] that by co-feeding $\mathrm{CH}_{3} \mathrm{I}$ and $\mathrm{D}_{2}$ over Pt single-crystals, $\mathrm{CH}_{\mathrm{x}}(\mathrm{x} \leq 3)$ specie are formed. They observed that (i) $\mathrm{CH}_{3} \mathrm{I}$ decomposes over Pt to give $\mathrm{CH}_{3}{ }^{*}$ and I* (ii) $\mathrm{CH}_{4}$ originates from the hydrogenation of $\mathrm{CH}_{\mathrm{x}}$ and (iii) $\mathrm{H}-\mathrm{D}$ exchange results in the formation of D-substituted analogs such as $\mathrm{CH}_{3} \mathrm{D}, \mathrm{CH}_{2} \mathrm{D}_{2}$, $\mathrm{CHD}_{3}$.

It was proposed earlier by us [2] that acetic acid decomposes during steam reforming over $\mathrm{Pt} / \mathrm{ZrO}_{2}$, to gas phase $\mathrm{CO}_{2}$ and sorbed $\mathrm{CH}_{\mathrm{x}}{ }^{*}$ and $\mathrm{H}^{*}$ specie. Thus, if $\mathrm{CH}_{3} \mathrm{COOD}$ is used, reactions between $\mathrm{CH}_{\mathrm{x}}{ }^{*}$ and $\mathrm{D} *$ can be expected. Occurrence of D-substituted analogs such as $\mathrm{CH}_{3} \mathrm{D}, \mathrm{CH}_{2} \mathrm{D}_{2}, \mathrm{CHD}_{3}$ (as above [11]), allows us to establish if $\mathrm{CH}_{\mathrm{x}}$ species [1,2] are relevant during steam reforming of acetic acid.

The objective of the present study is to suggest the reactive intermediate species involved when activating acetic acid over $\mathrm{Pt}$ and to complete the mechanistic pathways suggested earlier $[1,2]$ for the steam reforming of acetic acid over $\mathrm{Pt} / \mathrm{ZrO}$ catalysts. 


\subsection{Experimental}

A $10 \mathrm{mg}$ sample of 5wt.\% Pt/C (graphite) (commercial, Alfa Aesar, EG-nr. 231-955-3) diluted with quartz particles (1:5) was loaded in a fixed-bed reactor and held by quartz wool plugs. The catalyst was first reduced in-situ under $5 \% \mathrm{H}_{2} / \mathrm{Ar}$ flow $\left(50 \mathrm{ml} \cdot \mathrm{min}^{-1}\right)$ at $500{ }^{\circ} \mathrm{C}$ for $30 \mathrm{~min}$. After purging the reactor with Ar for $15 \mathrm{~min}$, the temperature was lowered to $320{ }^{\circ} \mathrm{C}$ [2] in order to prevent any homogenous decomposition of acetic acid as well as Pt metal sintering. $\mathrm{CH}_{3} \mathrm{COOD}$ (Aldrich, 99 at $\%$ D) or $\mathrm{CH}_{4}$ pulses (17.5 $\mu \mathrm{mol}$ each) were injected into the reactor, using a microsyringe. Outlet composition was measured online with a mass spectrometer (Balzers QMS 200 F). Unconverted acetic acid was delayed from the gas mixture using a cold trap. This helped to avoid overlapping of the MS-signals of the gaseous products formed, with those from acetic acid. Blank experiments indicated no decomposition of acetic acid at this temperature. Correspondingly, delayed broad signal attributed to acetic acid was only observed. All gaseous products were determined semi-quantitatively.

\subsection{Results and discussion}

Fig. 2.2 shows the spectra obtained during three subsequent pulses (I, II and III) of $\mathrm{CH}_{3} \mathrm{COOD}$ over $\mathrm{Pt} / \mathrm{C}$ (graphite) at $320{ }^{\circ} \mathrm{C}$. Contacting $\mathrm{CH}_{3} \mathrm{COOD}(\mathrm{m} / \mathrm{z} 43)$ over the catalyst resulted in the formation of the following species: $\mathrm{CO}_{2}(\mathrm{~m} / \mathrm{z} 44), \mathrm{CH}_{4}$ (m/z 16), $\mathrm{CH}_{3} \mathrm{D}(\mathrm{m} / \mathrm{z} 17), \mathrm{H}_{2}(\mathrm{~m} / \mathrm{z} 2), \mathrm{CH}_{2} \mathrm{D}_{2}$ (m/z 18), $\mathrm{HD}(\mathrm{m} / \mathrm{z} 3), \mathrm{CHD}_{3}(\mathrm{~m} / \mathrm{z} 19)$ and $\mathrm{D}_{2}(\mathrm{~m} / \mathrm{z} 4)$.

$\mathrm{CO}_{2}$ is formed when acetic acid decomposes over Pt, as shown by us earlier [1] and here it should come from $\mathrm{CH}_{3} \mathrm{COOD}$ according to eq. 2.1,

$$
\mathrm{CH}_{3} \mathrm{COOD}_{(\mathrm{g})}+2 * \rightarrow \mathrm{CH}_{3} *+\mathrm{CO}_{2(\mathrm{~g})}+\mathrm{D}^{*}
$$

where the symbol * denotes a metal site. $\mathrm{CH}_{3} \mathrm{D}$ and $\mathrm{D}_{2}$ (Fig. 2.2) can be primary desorption products assuming recombination on the catalyst surface of the species formed in eq. $2.1\left(\mathrm{CH}_{3} *\right.$ and $\left.\mathrm{D}^{*}\right)$. The other gaseous products observed $\left(\mathrm{CH}_{4}, \mathrm{CH}_{2} \mathrm{D}_{2}\right.$, $\mathrm{CHD}_{3}, \mathrm{H}_{2}$ and $\mathrm{HD}$ (see Fig. 2.2) cannot originate directly from the decomposition of $\mathrm{CH}_{3} \mathrm{COOD}$ according to eq. 2.1. Further, if the direct recombination of $\mathrm{CH}_{3} *$ with $\mathrm{D}^{*}$ was facile, these deuterated gas products would not have been observed. 
The following routes can be proposed, in agreement with Zaera [11] and Kemball [12], concerning methane formation, i.e., (i) hydrogen redistribution - via

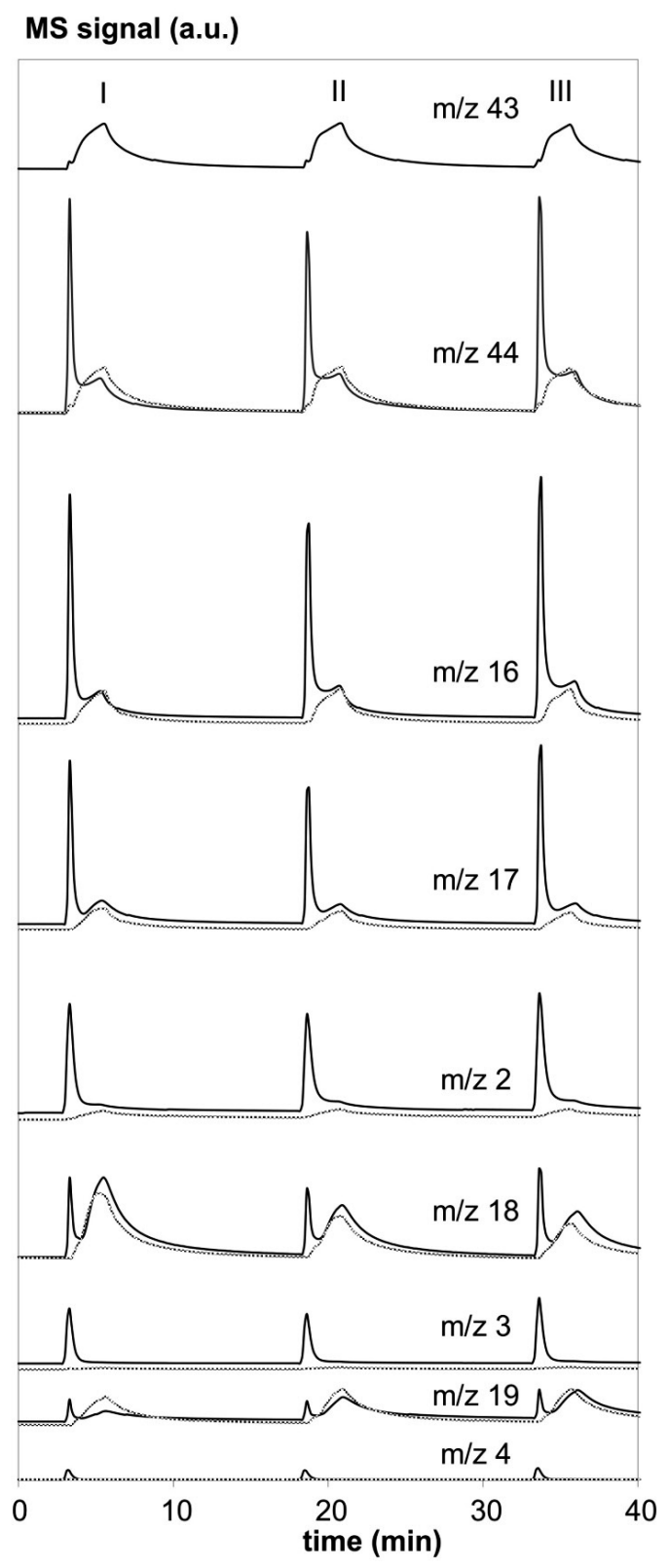

Fig. 2.2. Typical product distribution for $\mathrm{CH}_{3} \mathrm{COOD}$ pulses over $5 \mathrm{wt} . \% \mathrm{Pt} / \mathrm{C}$ (dark line) and over empty reactor (light line) at $320^{\circ} \mathrm{C}$. 
dehydrogenation/hydrogenation reactions among $\mathrm{CH}_{\mathrm{x}}(1 \leq \mathrm{x} \leq 3)$ species (e.g., $\mathrm{CH}_{3}$ (ads) $\rightleftarrows \mathrm{CH}_{2}$ (ads) $+\mathrm{H}($ ads $) ; \mathrm{CH}_{3}$ (ads) $+\mathrm{H}($ ads $) \rightarrow \mathrm{CH}_{4}$ (g), etc.) or (ii) hydrogen/deuterium redistribution among $\mathrm{CH}_{4-\mathrm{x}} \mathrm{D}_{\mathrm{x}}$ and surface $\mathrm{H}^{*}$ or $\mathrm{D}^{*}$ species (e.g., $\left.\mathrm{CH}_{3} \mathrm{D}(\mathrm{g})+\mathrm{H}(\mathrm{ads}) \rightleftarrows \mathrm{CH}_{4}(\mathrm{~g})+\mathrm{D}(\mathrm{ads})\right)$. In the former case a Langmuir-Hinshelwood and in the latter Eley Rideal type mechanisms are involved, as at least one of the specie is in the adsorbed state. The possibility of this Eley-Rideal type exchange is also reported by Guczi et al. [13] who observed exchange of $\mathrm{D}_{2}$ with $\mathrm{CH}_{4}$ over pure $\mathrm{Pt}$ in the temperature range from 300 to $400{ }^{\circ} \mathrm{C}$. Further, it is important to recall that gas phase (non catalytic) H-D exchange (e.g., between $\mathrm{CH}_{3} \mathrm{D}$ and $\mathrm{D}_{2}$ ) is not probable under the experimental conditions reported here [14-17].

From a pool of surface specie such as $\mathrm{CH}_{\mathrm{x}}(0 \leq \mathrm{x} \leq 3), \mathrm{H}$ and $\mathrm{D}$, all species such as $\mathrm{CH}_{4-\mathrm{x}} \mathrm{D}_{\mathrm{x}}$, (e.g. $\mathrm{CH}_{3} \mathrm{D}$ ) can be formed. Comparison of the amounts of "C"-based products based on elementary statistical probability calculation with those from our experiments showed that the amount of $\mathrm{CH}_{4}$ formed experimentally was larger than would be expected if $\mathrm{H}-\mathrm{D}$ redistribution was the only route for $\mathrm{CH}_{4}$ formation. $\mathrm{CH}_{4}$ (Expt - 45\%, Stat. - 32\%), $\mathrm{CH}_{3} \mathrm{D}(33 \%$, vs. $42 \%)$ and $\mathrm{CH}_{2} \mathrm{D}_{2}(16 \%$ vs. $21 \%)$ were observed in different amounts than predicted by statistical calculations. Deviations from statistics in our kinetic experiments may indicate that scrambling is not the only pathway for the formation of $\mathrm{CH}_{4-\mathrm{x}} \mathrm{D}_{\mathrm{x}},(0 \leq \mathrm{x} \leq 4)$ specie.

Observations so far supports our earlier proposition [1,2] that formation of $\mathrm{CH}_{\mathrm{x}}$ type species on $\mathrm{Pt}$ was involved in the steam reforming of acetic acid over $\mathrm{Pt} / \mathrm{ZrO}_{2}$. In the steam reforming of methane, activation of $\mathrm{CH}_{4}$ on metal-based catalyst is a crucial step. It is known [18] that methane activation, leading to the reactive $\mathrm{CH}_{\mathrm{x}}$ species for steam reforming, requires higher temperatures $\left(800^{\circ} \mathrm{C}\right)$ since it involves rupture of $\mathrm{C}-\mathrm{H}$ bond $\left(435 \mathrm{~kJ} \cdot \mathrm{mol}^{-1}[19]\right)$. Under our experimental conditions $\left(320^{\circ} \mathrm{C}\right)$, pulsing of $\mathrm{CH}_{4}$ over $\mathrm{Pt} / \mathrm{C}$ (graphite) resulted in no detectable methane conversion as well as no hydrogen and coke formation, confirming that methane indeed cannot be activated at such low temperature. However, in the case of acetic acid, fragmentation of the C-C bond, which is energetically more favorable $\left(368 \mathrm{~kJ} \cdot \mathrm{mol}^{-1},[19]\right)$ directly results in the reactive $\mathrm{CH}_{\mathrm{x}}$ type species. Thus, steam reforming of acetic acid follows a route similar to that proposed over $\mathrm{Pt} / \mathrm{ZrO}_{2}$ for methane steam reforming but can occur at milder temperatures. 


\subsection{Conclusions}

A detailed isotopic study of acetic acid activation on $\mathrm{Pt} / \mathrm{C}$ validates and completes the bifunctional mechanism for the steam reforming of acetic acid suggested in previous investigations. Observations of deuterated analogs of methane $\left(\mathrm{CH}_{4-\mathrm{x}} \mathrm{D}_{\mathrm{x}}, 0 \leq \mathrm{x} \leq 4\right)$ over $\mathrm{Pt} / \mathrm{C}$ (graphite) showed that $\mathrm{CH}_{3} \mathrm{COOD}$ activation occurs via $\mathrm{C}-\mathrm{C}$ bond activation, producing $\mathrm{CO}_{2}$ and similar to $\mathrm{CH}_{4}$ activation, forming $\mathrm{CH}_{\mathrm{x}}$ specie $(0 \leq \mathrm{x} \leq 3)$ which can be further steam reformed in the presence of $\mathrm{H}_{2} \mathrm{O}$. Presence of the $\mathrm{CH}_{4-\mathrm{x}} \mathrm{D}_{\mathrm{x}},(0 \leq \mathrm{x} \leq 4)$ suggests that the recombination of the primary surface species formed by the scission of $\mathrm{CH}_{3} \mathrm{COOD}$, i.e. $\mathrm{CH}_{3}{ }^{*}$ and $\mathrm{D}^{*}$, is not exclusive and scrambling reactions occur. The fact that acetic acid activation over Pt-based catalysts directly generates $\mathrm{CH}_{\mathrm{x}}$ specie is a key point to explain why acetic acid can be steam reformed under milder conditions than methane, which requires higher temperature to undergo $\mathrm{C}-\mathrm{H}$ bond activation. 


\section{References}

[1] K. Takanabe, K. Aika, K. Seshan, and L. Lefferts, Journal of Catalysis 227 (2004) 101-108.

[2] K. Takanabe, K.-i. Aika, K. Inazu, T. Baba, K. Seshan, and L. Lefferts, Journal of Catalysis 243 (2006) 263-269.

[3] D. Sutton, B. Kelleher, and J.R.H. Ross, Fuel Processing Technology 73 (2001) 155-173.

[4] J. H. Larsen, and I. Chorkendorff, Surface Science Reports 35 (1999) 163-222.

[5] J.R. Rostrup-Nielsen, Catalysis: Science and Technology 5 (1984) 1-117.

[6] J. Jupille, P. Pareja, and J. Fusy, Surface Science 139 (1984) 505-540.

[7] P.Z. Jiang, M.W. Bernasek, S.L. Robertson, Journal of Vacuum Science and Technology A 14 (1996).

[8] Y.M. Kino, F.Murakami, S. Yagyu, S. Yamamoto, Japanese Journal of Applied Physics Part 138 (1999).

[9] M.A. Henderson, Surface Science Reports 46 (2002) 1-308.

[10] D.A. Simonetti, E.L. Kunkes, and J.A. Dumesic, Journal of Catalysis 247 (2007) 298-306.

[11] F. Zaera, Catalysis Letters 11 (1991) 95-104.

[12] C. Kemball, Advance Catalysis 11 (1959) 223-262.

[13] L. Guczi, and Z. Karpinski, Journal of Catalysis 56 (1979) 438-444.

[14] T.V.W. Janssens, and F. Zaera, Surface Science 344 (1995) 77-84.

[15] A. Loaiza, M. Xu, and F. Zaera, Journal of Catalysis 159 (1996) 127-139.

[16] M. Montano, K. Bratlie, M. Salmeron, and G.A. Somorjai, Journal of the American Chemistry Society 128 (2006) 13229-13234.

[17] O.V. Buyevskaya, M. Rothaemel, H.W. Zanthoff, and M. Baerns, Journal of Catalysis 146 (1994) 346-357.

[18] J. Wei, and E. Iglesia, The Journal of Physical Chemistry B 108 (2004) 4094-4103.

[19] P.W. Atkins, Physical Chemistry, Oxford University, London, 2006. 



\section{Chapter}

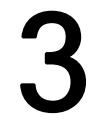

\section{Steam reforming of acetic acid over platinum catalysts - Influence of oxygen and red-ox supports.}

The influence of the support and the presence of oxygen were investigated in the steam reforming of acetic acid, a pyrolysis oil model compound, over $\mathrm{Pt} / \mathrm{ZrO} \mathrm{O}_{2}$ and $\mathrm{Pt} / \mathrm{CeO}_{2}$ catalysts. In the absence of oxygen, all catalysts suffered from deactivation. Acetone, formed via condensation/dehydration of acetic acid, is a coke precursor and causes catalyst deactivation. The use of a support with red-ox properties and the presence of oxygen improved the stability of the $\mathrm{Pt} / \mathrm{CeO}_{2}$ catalyst tremendously. MALDI-TOF MS characterization of coke indicated that the presence of oxygen prevents extensive oligomerization/coke forming reactions and that the resulting specie are more easily combusted. 



\subsection{Introduction}

The concept of hydrogen as energy carrier is currently of interest, particularly within the context of sustainable development $[1,2]$. Biomass has recently drawn attention as a renewable hydrogen source, i.e. with no net contribution to $\mathrm{CO}_{2}$ emissions. In the context of biomass, flash pyrolysis of lignocelluloses results in liquid pyrolysis oil, a convenient feedstock for storage, transport and processing [3]. Catalytic steam reforming followed by water-gas shift is a standard commercial route and can be applied to maximize hydrogen yield from pyrolysis oil. The complexity of pyrolysis oils makes it difficult to design catalysts based on kinetic and spectroscopic studies and to establish reaction mechanisms. Thus, model representative components are often used. In this context, in the steam reforming of acetic acid, a major component in pyrolysis oil [3-5], we have previously shown excellent activity for $\mathrm{Pt} / \mathrm{ZrO}_{2}$ at relatively low temperatures $\left(450^{\circ} \mathrm{C}\right)[6]$. However, catalyst stability was a major problem and $\mathrm{Pt} / \mathrm{ZrO}_{2}$ suffered from rapid deactivation. Based on our previous studies [6-8] we can generally conclude that higher temperatures, close to natural gas reforming, are required to minimize coking and extend catalyst stability.

We proposed earlier a bi-functional mechanism [6, 7] where Pt and $\mathrm{ZrO}_{2}$ are involved in the steam reforming of acetic acid $(\mathrm{AcOH})$. The role of $\mathrm{ZrO}_{2}$ is in the activation of water forming hydroxyl groups. However, acetic acid undergoes condensation/dehydration reactions on $\mathrm{ZrO}_{2}$ resulting in the formation of carbonaceous deposits that cause deactivation. In this respect, a thorough understanding of the coke formation is fundamental to understand the deactivation mechanism and to design stable catalysts.

It is reported $[9,10]$ that catalyst stability for steam reforming can be improved by addition of small amounts of oxygen. Cavallaro et al. [9] reported a better stability for $\mathrm{Rh} / \mathrm{Al}_{2} \mathrm{O}_{3}$ during the steam reforming of ethanol when ca. $3 \% \mathrm{O}_{2}$ was added to the reaction mixture. The positive effect was attributed to the in-situ combustion of carbonaceous specie formed during reaction. Further, Lima et al. [10] have recently reported improvement in the $\mathrm{Pt} / \mathrm{CeZrO}_{2}$ stability for the steam reforming of ethanol, when adding oxygen in the feed $\left(\mathrm{O}_{2} /\right.$ ethanol molar ratio of 0.5$)$. Oxygen availability for gasification of coke deposited on the support can be enhanced by using reducible 
supports such as $\mathrm{CeO}_{2}[11,12]$. Ability of these metal oxides to store and release oxygen, the so called "oxygen storage capacity (OSC)" [12-14], may help to minimize/prevent coke accumulation and result in more stable catalysts.

Current research aims at improving the catalytic stability of Pt-based catalysts for steam reforming of acetic acid. Two approaches are identified, i.e., (i) use of oxide supports with red-ox properties, e.g., $\mathrm{CeO}_{2}$ and (ii) carrying out reforming under mild autothermal conditions, i.e., introducing low amounts of $\mathrm{O}_{2}$ in the feed. Matrix assisted laser desorption/ionization time-of-flight mass spectrometry (MALDI-TOF MS) characterization of the coke allows an insight in the mechanism of coke formation, or in the relationship between coke properties and deactivation.

\subsection{Experimental}

\subsubsection{Catalyst preparation}

Catalysts were prepared by wet impregnation technique. An aqueous solution of $\mathrm{H}_{2} \mathrm{PtCl}_{6} \cdot 6 \mathrm{H}_{2} \mathrm{O}$ was used (Alfa Aesar). $\mathrm{ZrO}_{2}$ (Daiichi Kigenso Kagaku Kogio, RC 100) and $\mathrm{CeO}_{2}$ (Aldrich) were first calcined for $15 \mathrm{~h}$ at $850{ }^{\circ} \mathrm{C}$ (heating rate $5{ }^{\circ} \mathrm{C} \cdot \mathrm{min}^{-1}$ ) in flowing air $\left(30 \mathrm{ml} \cdot \mathrm{min}^{-1}\right)$. The supports were then crushed and sieved to give grains of 0.3-0.6 mm. The grains were impregnated with the $\mathrm{H}_{2} \mathrm{PtCl}_{6} \cdot 6 \mathrm{H}_{2} \mathrm{O}$ solution to yield to 0.5 wt.\% Pt. The catalysts were dried for $4 \mathrm{~h}$ at $70{ }^{\circ} \mathrm{C}$ in vacuum and subsequently calcined at $725^{\circ} \mathrm{C}$ for $15 \mathrm{~h}$ (heating rate $\left.5^{\circ} \mathrm{C} \cdot \mathrm{min}^{-1}\right)$ in flowing air $\left(30 \mathrm{ml} \cdot \mathrm{min}^{-1}\right)$.

\subsubsection{Catalyst characterization}

The elemental compositions of the catalysts were determined with X-ray fluorescence spectroscopy (XRF) (Phillips PW 1480 spectrometer). Specific surface area measurements were carried out by the BET method (Micromeritics TriStar).

$\mathrm{H}_{2}$ chemisorption (Chemisorb 2750, Micromeritics) measurements were carried out to determine the Pt dispersions. Reducibility of the catalysts and supports was probed using temperature-programmed reduction (TPR) equipped with thermal conductivity detector. For this purpose, $50 \mathrm{mg}$ of catalyst sample was pretreated in $\mathrm{Ar}$ at $700{ }^{\circ} \mathrm{C}$ for $5 \mathrm{~min}$. After pretreatment, the sample was first cooled down to room temperature in $\mathrm{Ar}$ and then heated to $800{ }^{\circ} \mathrm{C}$ at a rate of $5{ }^{\circ} \mathrm{C} \cdot \mathrm{min}^{-1}$ in a $5 \% \mathrm{H}_{2} / \mathrm{Ar}$ flow $\left(30 \mathrm{ml} \cdot \mathrm{min}^{-1}\right)$. 
The red-ox changes of $\mathrm{CeO}_{2}$ during sequential reduction/oxidation treatments in hydrogen and water, respectively, were also tested in the same TPR setup. About $100 \mathrm{mg}$ of $\mathrm{Pt} / \mathrm{CeO}_{2}$ was first heated to $900{ }^{\circ} \mathrm{C}$ in $5 \% \mathrm{H}_{2} / \mathrm{Ar}$ at $5{ }^{\circ} \mathrm{C} \cdot \mathrm{min}^{-1}$ and then purged with He for $15 \mathrm{~min}$. at the same temperature. Subsequently, the gas flow was changed to $2.3 \% \mathrm{H}_{2} \mathrm{O} / \mathrm{He}$ and the catalyst was cooled down to $50{ }^{\circ} \mathrm{C}$. After purging the system with $\mathrm{He}$ for $15 \mathrm{~min}$, the sample was heated again to $900{ }^{\circ} \mathrm{C}$ in $5 \% \mathrm{H}_{2} / \mathrm{Ar}$ at $5^{\circ} \mathrm{C} \cdot \mathrm{min}^{-1}$.

Temperature program oxidation (TPO) experiments were performed to quantify the amount of coke deposits on the used catalyst. Samples were heated from room temperature to $800{ }^{\circ} \mathrm{C}$ in $1 \% \mathrm{O}_{2} / \mathrm{Ar}$ at $5{ }^{\circ} \mathrm{C} \cdot \mathrm{min}^{-1}$. Carbonaceous deposits were oxidized to $\mathrm{CO}_{\mathrm{x}}$, which passed through a methanator and was finally detected with a flame ionization detector. This enabled to differentiate between oxygen consumption during TPO for coke removal or re-oxidation of ceria.

For MALDI-TOF MS analysis, the method of C. Sievers et al. [15] was utilized, with only slight modifications. $10 \mathrm{mg}$ of the spent catalyst was suspended in $250 \mu 1$ of $1 \%$ trifluoroacetic acid solution (HPLC Grade, from Fisher Scientific) and $250 \mu 1$ of $10 \mathrm{mg} / \mathrm{ml}$ 2,5-dihydrobenzoic acid (DHB) (Sigma-Aldrich). The solution was mixed for $30 \mathrm{sec}$ using a vortex mixer, ultrasonicated for 30 minutes, and centrifuged for $30 \mathrm{sec}$ at 1000 RPM. $2 \mu \mathrm{l}$ of supernatant was pipetted onto a stainless steel MALDI plate, and mass spectra were recorded using a Waters SYNAPT HDMS MALDI-TOF mass spectrometer (Waters, USA). The spectrometer was operated in positive ion mode, and was calibrated using a polyethylene glycol (PEG) standard.

\subsubsection{Catalytic testing}

For catalytic experiments, $100 \mathrm{mg}$ of catalyst with grains of $0.3-0.6 \mathrm{~mm}$ was loaded in a fixed-bed reactor ( $4 \mathrm{~mm}$ i.d.) and held by quartz wool plugs. The catalyst was first reduced in-situ in $5 \% \mathrm{H}_{2} / \mathrm{N}_{2}$ flow $\left(50 \mathrm{ml} \cdot \mathrm{min}^{-1}\right)$ at $550{ }^{\circ} \mathrm{C}$ for $1 \mathrm{~h}$. After purging with $\mathrm{N}_{2}$ for $15 \mathrm{~min}$, the temperature was increased to $700{ }^{\circ} \mathrm{C}$. An aqueous solution of acetic acid with a steam to carbon molar ratio $(\mathrm{S} / \mathrm{C})$ of 5 was delivered by a pulse-free syringe pump (Isco Model 500 D). This solution was evaporated at $190{ }^{\circ} \mathrm{C}$ in a gasifier before entering the reactor. Nitrogen was used both as an inert carrier gas and as an internal standard. The feed delivery system was heated at $175^{\circ} \mathrm{C}$ 
to avoid condensation. The gas feed, consisting of $2.5 \% \mathrm{CH}_{3} \mathrm{COOH} / 25 \% \mathrm{H}_{2} \mathrm{O} /$ balance $\mathrm{N}_{2}$, was introduced to the fixed-bed reactor. For continuous flow experiments in which oxygen was added in the stream, the gas mixture composition was $2.5 \% \mathrm{CH}_{3} \mathrm{COOH} / 25 \% \mathrm{H}_{2} \mathrm{O} / 1 \% \mathrm{O}_{2} /$ balance $\mathrm{N}_{2}$. For blank experiments, $100 \mathrm{mg}$ of quartz particles was loaded in the fixed-bed reactor and held by quartz wool plugs. The total gas hourly space velocity (GHSV) was calculated on a volume basis $\left(80000 \mathrm{~h}^{-1}\right)$.

The composition of the product mixture was determined with an on-line gas chromatograph (GC, Varian CP-3800) equipped with Hayesep Q, Hayesep T, Molsieve 13X, Molsieve 5A and CP-Wax 52CB columns for separation. For the quantification of permanent gases, two thermal conductivity detectors (TCD) were used, while for quantification of the hydrocarbons a flame ionization detector (FID) was applied.

Acetic acid conversion was calculated as the number of moles of acetic acid reacted divided by the number of moles of acetic acid fed.

The hydrogen yield was defined as the percentage of the maximum amount of hydrogen that can be produced, based on Eq. 3.1.

$$
\mathrm{CH}_{3} \mathrm{COOH}+2 \mathrm{H}_{2} \mathrm{O} \rightarrow 2 \mathrm{CO}_{2}+4 \mathrm{H}_{2}
$$

For carbon-containing compounds, the yields were calculated based on $\mathrm{C}_{1}$ equivalent values.

\subsection{Results}

\subsubsection{Catalyst characterization}

Physico-chemical characteristics of the catalysts are summarized in Table 3.1. The two catalysts had comparable Pt loadings ( $\sim 0.5 \mathrm{wt} . \%)$, dispersions (14-16\%) and BET surface area of around $18 \mathrm{~m}^{2} \cdot \mathrm{g}^{-1}$. This allows realistic comparison of the two catalysts in their catalytic performance. 
Table 3.1. Metal loading, Pt dispersion and BET surface area of the catalysts used in this work

\begin{tabular}{lccc}
\hline Catalyst & Pt content (wt.\%) & Dispersion (\%) & Surface area $\left(\mathrm{m}^{2} \cdot \mathrm{g}^{-1}\right)$ \\
\hline $\mathrm{Pt} / \mathrm{ZrO}_{2}$ & 0.52 & 16 & 17.1 \\
$\mathrm{Pt} / \mathrm{CeO}_{2}$ & 0.55 & 14 & 18.2 \\
\hline
\end{tabular}

The hydrogen uptake by $\mathrm{Pt} / \mathrm{ZrO}_{2}$ and $\mathrm{Pt} / \mathrm{CeO}_{2}$ as a function of temperature is shown in Fig. 3.1. The peak around $250{ }^{\circ} \mathrm{C}$ in both cases corresponds to reduction of platina. In the case of $\mathrm{Pt} / \mathrm{ZrO}_{2}$ no reduction peak for $\mathrm{ZrO}_{2}$ was observed. In the $\mathrm{Pt} / \mathrm{CeO}_{2}$ the $\mathrm{CeO}_{2}$ showed broad and significant reduction starting from around $500{ }^{\circ} \mathrm{C}$. This peak is due to the reduction of lattice oxygen of $\mathrm{CeO}_{2}$ [16-18]. The TPR profiles clearly show that only $\mathrm{CeO}_{2}$ allows red-ox changes at the reaction temperature used in this study $\left(700^{\circ} \mathrm{C}\right)$.

TPR profiles of (i) a freshly calcined $\mathrm{Pt} / \mathrm{CeO}_{2}$ catalyst and (ii) the resulting reduced catalyst after exposure to water are shown in Fig. 3.2. It can be seen from the figure that the reduction peak, around $830{ }^{\circ} \mathrm{C}$, reappears indicating re-oxidation of ceria with water during exposure at $700{ }^{\circ} \mathrm{C}$ and cooling down. Re-oxidation of platinum was not observed during this experiment.

\subsubsection{Catalyst measurements}

Product distribution of homogeneous decomposition of acetic acid $(\mathrm{AcOH})$ during time on stream (TOS) is shown in Fig. 3.3a. Approximately $20 \%$ conversion of

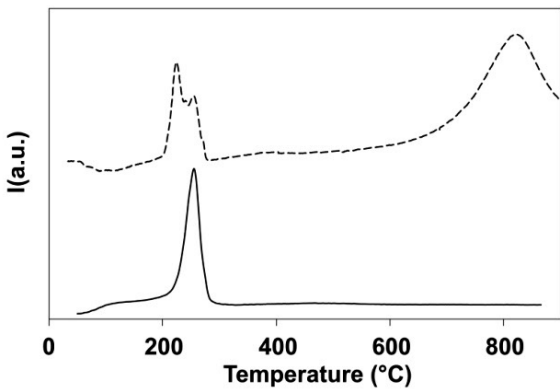

Fig. 3.1. Temperature program reduction of fresh preheated $\mathrm{Pt} / \mathrm{ZrO}_{2}(-)$ and $\mathrm{Pt} / \mathrm{CeO}_{2}(. .$.$) .$

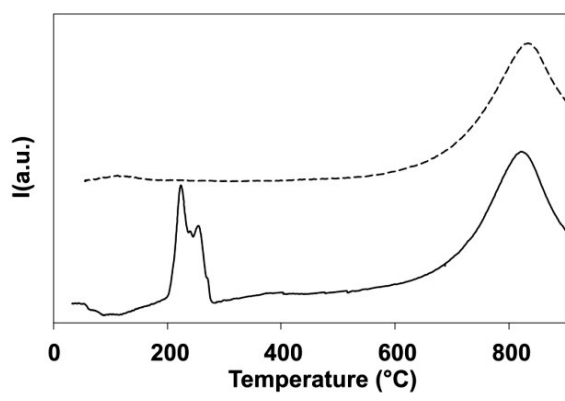

Fig. 3.2. Temperature program reduction of fresh preheated $\mathrm{Pt} / \mathrm{CeO}_{2}(-)$ and $\mathrm{Pt} / \mathrm{CeO}_{2}$ re-oxidized by water after being previously reduced (....). 
products observed were $\mathrm{H}_{2}, \mathrm{CO}$ and $\mathrm{CO}_{2}$. This indicates that $\mathrm{AcOH}$ undergoes thermal decomposition at $700{ }^{\circ} \mathrm{C}$. Higher $\mathrm{AcOH}$ conversions $(\sim 50 \%)$ were observed when $1 \% \mathrm{O}_{2}$ was added in the gas stream (Fig. 3.3b). This increase in conversion resulted in higher $\mathrm{CO}$ and $\mathrm{CO}_{2}$ yields. Only traces of hydrogen were detected. Oxygen consumption was complete in all experiments. Carbon balance was $\sim 85 \%$ in both cases, indicating that part of the acetic acid was converted to some by-products undetected during analysis.
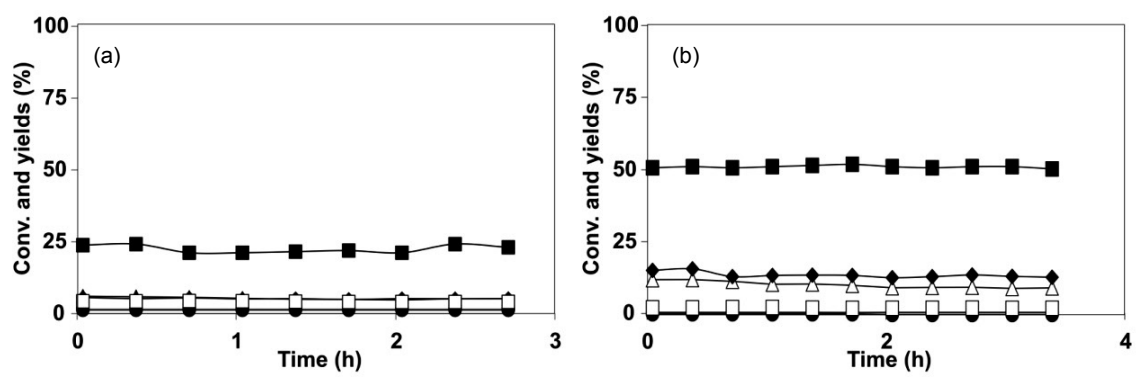

Fig. 3.3. Conversion and yields vs. time on stream for the steam reforming of AcOH over quartz particles in the absence (a) and presence (b) of oxygen $\left(1 \% \mathrm{O}_{2}\right)$. Reaction conditions: $700{ }^{\circ} \mathrm{C}, \mathrm{S} / \mathrm{C}=5$, $\mathrm{GHSV}=80000 \mathrm{~h}^{-1}$. (•) AcOH; $(\bullet) \mathrm{CO}_{2} ;(\bullet)$ Acetone; (口) $\mathrm{H}_{2} ;(\Delta) \mathrm{CO} ;(\circ) \mathrm{CH}_{4}$.

\subsubsection{Steam reforming of acetic acid over $\mathrm{ZrO}_{2}$ and $\mathrm{Pt} / \mathrm{ZrO} \mathrm{O}_{2}$}

Fig. 3.4a shows AcOH conversion and product yields during steam reforming over $\mathrm{ZrO}_{2}$ at $700{ }^{\circ} \mathrm{C}$. At initial TOS, AcOH was almost completely converted (95\%) to $\mathrm{CO}_{2}, \mathrm{CH}_{4}, \mathrm{H}_{2}$ and $\mathrm{CO}$. After $30 \mathrm{~min}$. TOS, significant amounts of acetone were detected in the product stream, but disappeared after approximately 45 min TOS. Rapid deactivation of the catalyst was apparent during this period as evidenced by the decrease in $\mathrm{AcOH}$ conversion and gas yields. After $1 \mathrm{~h}$ TOS the system reached steady state, with $\mathrm{AcOH}$ conversion and product distribution similar to that due to gas phase reactions (Fig. 3.3a). The addition of $1 \% \mathrm{O}_{2}$ (Fig. 3.4b) resulted only in a slight increase of $\mathrm{CO}$ and decrease in $\mathrm{H}_{2}$ and $\mathrm{CH}_{4}$ yields. Acetone was observed again but deactivation occurred to a lesser extent. After $1 \mathrm{~h}$ TOS the conversion and product distribution remained unchanged and were similar to the results obtained during thermal cracking of acetic acid with the presence of oxygen. 

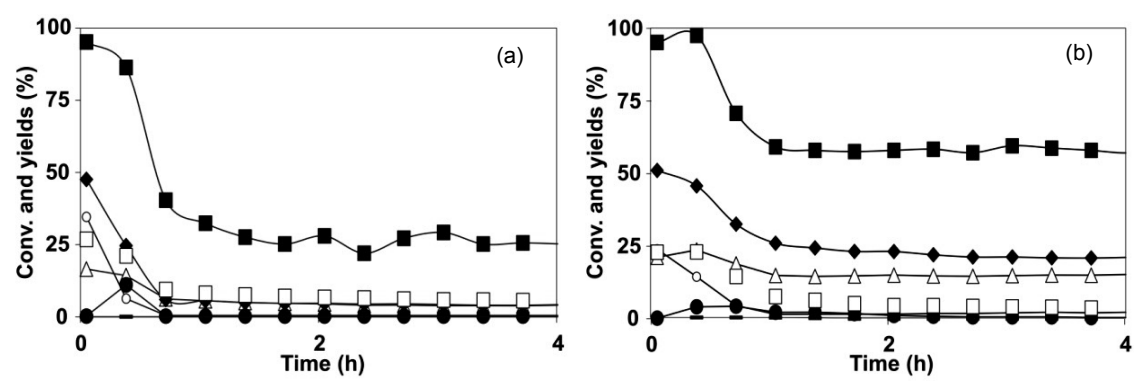

Fig. 3.4. Conversion and yields vs. time on stream for the steam reforming of $\mathrm{AcOH}$ over $\mathrm{ZrO}_{2}$ in the absence (a) and presence (b) of oxygen $\left(1 \% \mathrm{O}_{2}\right)$. Reaction conditions: $700{ }^{\circ} \mathrm{C}, \mathrm{S} / \mathrm{C}=5$, $\mathrm{GHSV}=80000 \mathrm{~h}^{-1}$. (•) AcOH; $(\bullet) \mathrm{CO}_{2} ;(\bullet)$ Acetone; (口) $\mathrm{H}_{2} ;(\Delta) \mathrm{CO} ;(\circ) \mathrm{CH}_{4}$.

Fig. 3.5a represents a typical experimental result of steam reforming of $\mathrm{AcOH}$ over $\mathrm{Pt} / \mathrm{ZrO}_{2}$ at $700{ }^{\circ} \mathrm{C}$. As can be seen, product distribution is completely different from that with $\mathrm{ZrO}_{2}$ (Fig. 3.4a) and changed drastically in time. Initially, AcOH was mostly converted to $\mathrm{H}_{2}$ and $\mathrm{CO}_{2} ; \mathrm{CO}$ and $\mathrm{CH}_{4}$ were observed in smaller amounts. After $40 \mathrm{~min}$. TOS acetone was observed as a product. At that time, $\mathrm{H}_{2}$ and $\mathrm{CO}_{2}$ yields decreased significantly. $\mathrm{CO}$ decreased to a lesser extent. $\mathrm{CH}_{4}$ practically disappeared. After $3.5 \mathrm{~h}$ TOS the system reached steady state. AcOH conversion decreased to $23 \%$, which corresponded to gas phase thermal decomposition of $\mathrm{AcOH}$.

The influence of oxygen on $\mathrm{Pt} / \mathrm{ZrO}_{2}$ is shown in Fig. 3.5b. The complete conversion of $\mathrm{AcOH}$ during the first $3.5 \mathrm{~h}$ TOS clearly shows an improvement in catalyst lifetime as compared to steam reforming without oxygen. During this period of time $(3.5 \mathrm{~h})$, only steam reforming products $\left(\mathrm{H}_{2}, \mathrm{CO}_{2}\right.$ and $\left.\mathrm{CO}\right)$ were observed. The addition of $\mathrm{O}_{2}$ to the reaction mixture resulted in slightly higher $\mathrm{CO}$ and $\mathrm{CO}_{2}$ yields. $\mathrm{H}_{2}$ yield decreased from 85 to $70 \%$. Again, the observation of a rapid decrease in conversion and gas product yields after $3.5 \mathrm{~h}$ TOS was evidence for catalyst deactivation. Acetone appeared in the gas phase during deactivation, reaching a maximum at $4 \mathrm{~h}$ TOS. These changes led to a new steady state that clearly differed from the product distribution corresponding to thermal cracking of $\mathrm{AcOH}$ in the presence of oxygen. 

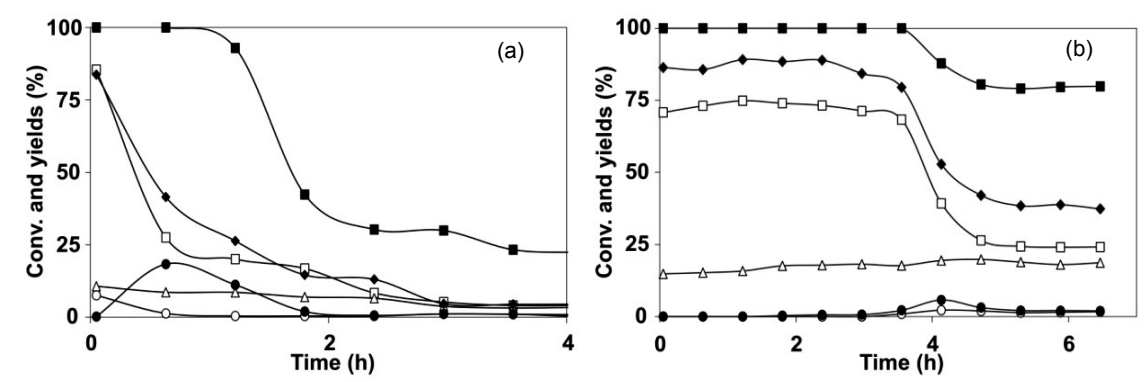

Fig. 3.5. Conversion and yields vs. time on stream for the steam reforming of $\mathrm{AcOH}$ over $\mathrm{Pt} / \mathrm{ZrO}_{2}$ in the absence (a) and presence (b) of oxygen $\left(1 \% \mathrm{O}_{2}\right)$. Reaction conditions: $700{ }^{\circ} \mathrm{C}, \mathrm{S} / \mathrm{C}=5$, $\left.\mathrm{GHSV}=80000 \mathrm{~h}^{-1}\right)$. (•) AcOH; $(\bullet) \mathrm{CO}_{2} ;(\bullet)$ Acetone; () $\mathrm{H}_{2} ;(\Delta) \mathrm{CO}$; ( $) \mathrm{CH}_{4}$.

\subsubsection{Steam reforming of acetic acid over $\mathrm{CeO}_{2}$ and $\mathrm{Pt} / \mathrm{CeO}$}

Fig. 3.6a shows $\mathrm{AcOH}$ conversion and product yields over $\mathrm{CeO}_{2}$ at $700{ }^{\circ} \mathrm{C}$. Initial AcOH conversion was nearly complete, leading to $\mathrm{CO}_{2}, \mathrm{H}_{2}, \mathrm{CH}_{4}$ and $\mathrm{CO}$. In contrast to $\mathrm{ZrO}_{2}$, deactivation of $\mathrm{CeO}_{2}$ occurred more gradually. Another significant difference between the two supports is that smaller amounts of acetone were observed over $\mathrm{CeO}_{2}$. The effect of adding $1 \% \mathrm{O}_{2}$ in the steam reforming of $\mathrm{AcOH}$ over $\mathrm{CeO}_{2}$ is illustrated in Fig. 3.6b. Complete conversion of $\mathrm{AcOH}$ was achieved during the first two hours of reaction. $\mathrm{CO}_{2}, \mathrm{H}_{2}, \mathrm{CH}_{4}$ and $\mathrm{CO}$ were observed as products. The stability of $\mathrm{CeO}_{2}$ was improved, as evidenced by the reasonably stable product yields during the $4 \mathrm{~h}$ TOS.
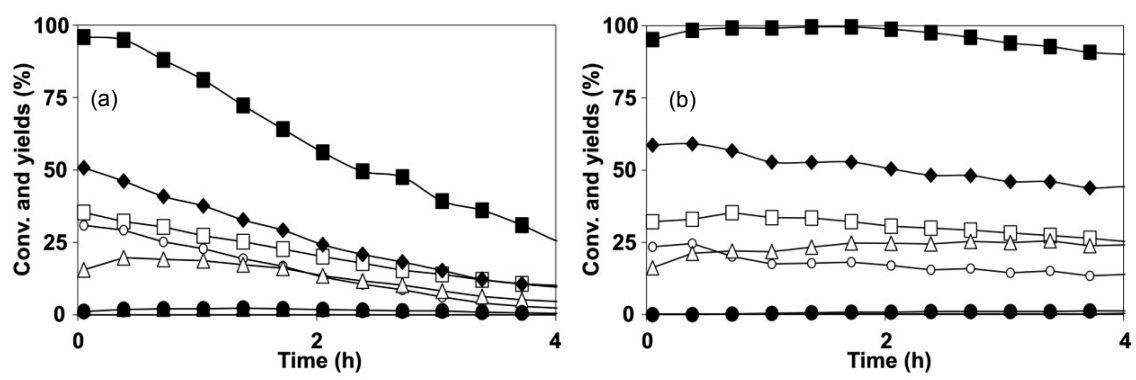

Fig. 3.6. Conversion and yields vs. time on stream for the steam reforming of $\mathrm{AcOH}$ over $\mathrm{CeO}_{2}$ in the absence (a) and presence (b) of oxygen $\left(\begin{array}{ll}1 \% & \mathrm{O}_{2}\end{array}\right)$. Reaction conditions: $700{ }^{\circ} \mathrm{C}, \mathrm{S} / \mathrm{C}=5$, $\mathrm{GHSV}=80000 \mathrm{~h}^{-1}$. (•) AcOH; $\left(\bullet \mathrm{CO}_{2} ;(\bullet)\right.$ Acetone; (口) $\mathrm{H}_{2} ;(\Delta) \mathrm{CO} ;(\circ) \mathrm{CH}_{4}$.

Catalytic performance of $\mathrm{Pt} / \mathrm{CeO}_{2}$ is shown in Fig. 3.7a. This catalyst also showed very high initial activity, with product yields close to thermodynamic equilibrium [i.e. $\mathrm{H}_{2}\left(92 \%\right.$ yield) and $\mathrm{CO}_{2}(79 \%$ yield $\left.)\right]$. Traces of acetone were observed. However, $\mathrm{Pt} / \mathrm{CeO}_{2}$ was more stable catalyst for the steam reforming than 
$\mathrm{Pt} / \mathrm{ZrO}_{2}$ under identical conditions and deactivated more gradually during the $10 \mathrm{~h}$ TOS measured (Figs. 3.5a and 3.7a).

In the presence of $\mathrm{O}_{2}$ (Fig. 3.7b), interestingly, $\mathrm{Pt} / \mathrm{CeO}_{2}$ showed excellent stability in terms of $\mathrm{H}_{2}$ production. No deactivation was observed during the $10 \mathrm{~h}$ TOS. Steam reforming and water-gas shift products $\left[\mathrm{H}_{2}(75 \%\right.$ yield $), \mathrm{CO}$ (16\% yield) and $\mathrm{CO}_{2}(75 \%$ yield $\left.)\right]$ were the only gases observed throughout the experiment.
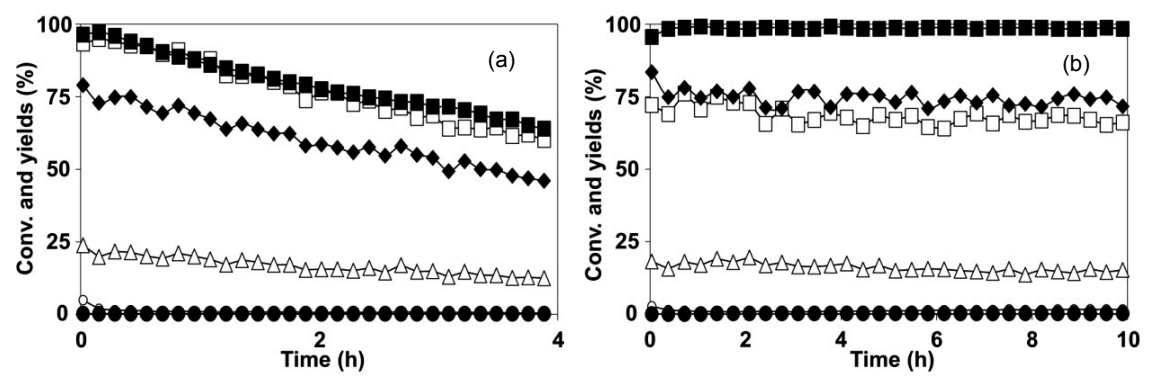

Fig. 3.7. Conversion and yields vs. time on stream for the steam reforming of $\mathrm{AcOH}$ over $\mathrm{Pt} / \mathrm{CeO}_{2}$ in the absence (a) and presence (b) of oxygen $\left(1 \% \mathrm{O}_{2}\right)$. Reaction conditions: $700{ }^{\circ} \mathrm{C}, \mathrm{S} / \mathrm{C}=5$,

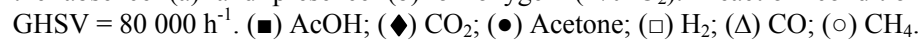

\subsubsection{Steam reforming of acetone over $\mathrm{Pt} / \mathrm{ZrO} \mathrm{O}_{2}$ and $\mathrm{Pt} / \mathrm{CeO} \mathrm{O}_{2}$}

Fig. 3.8a shows the conversion and product distribution during steam reforming of acetone over $\mathrm{Pt} / \mathrm{ZrO}_{2}$ at $700{ }^{\circ} \mathrm{C}$. Very high activity was observed in the beginning of the reaction, with complete conversion of acetone. Similar to the steam reforming of $\mathrm{AcOH}, \mathrm{H}_{2}$ and $\mathrm{CO}_{2}$ were observed as main products, with yields around $70 \%$ and $60 \%$, respectively. $\mathrm{CO}$ (25\% yield) and $\mathrm{CH}_{4}$ (10\% yield) were detected in lower amounts. Drastic catalyst deactivation was noticed after few minutes of reaction. This resulted in a new steady state in which only $20 \%$ acetone was converted. The products were $\mathrm{H}_{2}, \mathrm{CO}_{2}$ and $\mathrm{CO}$.

Like $\mathrm{Pt} / \mathrm{ZrO}_{2}$, steam reforming of acetone over $\mathrm{Pt} / \mathrm{CeO}_{2}$ (Fig. 3.8b) resulted in complete acetone conversion at initial TOS and comparable product distribution. However, using $\mathrm{CeO}_{2}$ as a support improved the catalyst stability greatly. No decrease in $\mathrm{H}_{2}$ yield was observed during $10 \mathrm{~h}$ TOS. 

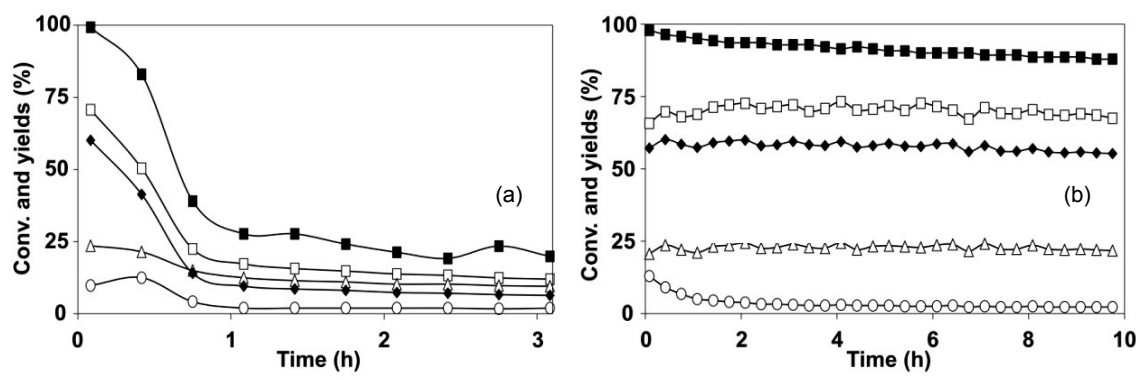

Fig. 3.8. Conversion and yields vs. time on stream for the steam reforming of acetone over $\mathrm{Pt} / \mathrm{ZrO}_{2}$ (a) and $\mathrm{Pt} / \mathrm{CeO}_{2}$ (b). Reaction conditions: $700{ }^{\circ} \mathrm{C}, \mathrm{S} / \mathrm{C}=5$, GHSV $=96000 \mathrm{~h}^{-1}$. (a)Acetone; ( $) \mathrm{CO}_{2}$; (口) $\mathrm{H}_{2} ;(\Delta) \mathrm{CO} ;(\circ) \mathrm{CH}_{4}$.

\subsubsection{Characterization of deactivated catalysts}

The amounts of coke deposits accumulated on the catalysts after $6 \mathrm{~h}$ TOS are listed in Table 3.2. Clearly, more coke was detected on the catalysts used in the absence of $\mathrm{O}_{2}$. The carbonaceous deposits accumulated on $\mathrm{Pt} / \mathrm{ZrO}_{2}(0.9$ wt.\%) were greater than those deposited on $\mathrm{Pt} / \mathrm{CeO}_{2}(0.7$ wt.\%) despite of the same TOS. Addition of $1 \% \mathrm{O}_{2}$ resulted in a similar trend, i.e., less coke was found when $\mathrm{CeO}_{2}$ was used as a support.

Table 3.2. Coke amount after $6 \mathrm{~h}$ time on stream over: $\mathrm{Pt} / \mathrm{ZrO}_{2}$ and $\mathrm{Pt} / \mathrm{CeO}_{2}$.

\begin{tabular}{lcc}
\hline \multirow{2}{*}{ Catalyst } & \multicolumn{2}{c}{ Percentage of coke deposited (\%) } \\
\cline { 2 - 3 } & Presence of $\mathrm{O}_{2}$ & Absence of $\mathrm{O}_{2}$ \\
\hline $\mathrm{Pt} / \mathrm{ZrO}_{2}$ & 0.6 & 0.9 \\
$\mathrm{Pt} / \mathrm{CeO}_{2}$ & 0.3 & 0.7 \\
\hline
\end{tabular}

In order to investigate the coke on the spent catalysts, MALDI-TOF MS spectra of the carbonaceous deposits were recorded. Fig. 3.9a compares the spectra corresponding to coke deposits on $\mathrm{Pt} / \mathrm{ZrO}_{2}$ in the presence and absence of $\mathrm{O}_{2}$ during steam reforming. Both spectra reveal a broad molecular weight distribution up to $600 \mathrm{~m} / \mathrm{z}$, which was the largest mass recorded. In the presence of oxygen, the dominating mass signals were found below $300 \mathrm{~m} / \mathrm{z}$. In contrast, the spectrum corresponding to the coke formed during steam reforming in the absence of oxygen shows that the strongest peaks appear above $400 \mathrm{~m} / \mathrm{z}$. Similar trends were observed 
for the $\mathrm{Pt} / \mathrm{CeO}_{2}$ catalyst (Fig. 3.9b). A main peak around $300 \mathrm{~m} / \mathrm{z}$ was observed in the spectrum associated to the coke developed in oxidative conditions, whereas the dominating species in the absence of oxygen was observed around $450 \mathrm{~m} / \mathrm{z}$.
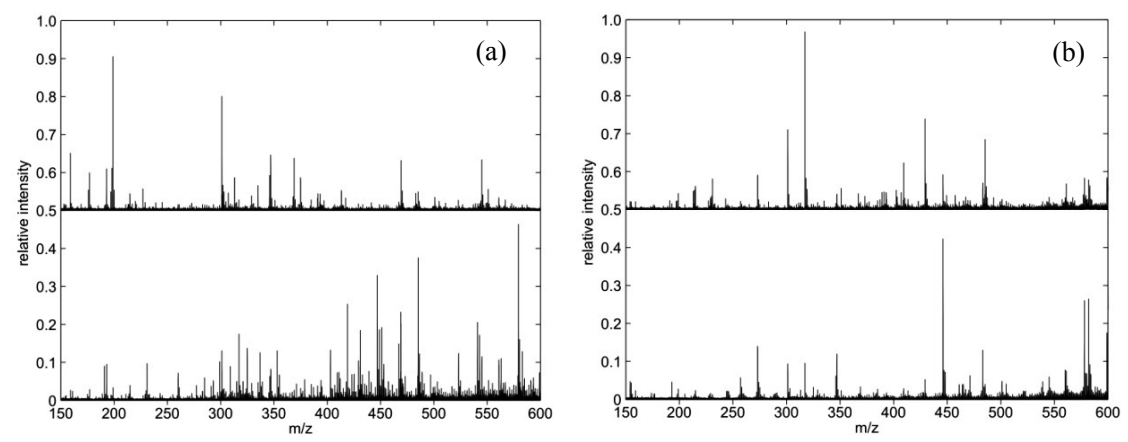

Fig. 3.9. MALDI-TOF MS spectra of coke deposited on (a) $\mathrm{Pt} / \mathrm{ZrO}_{2}$ and (b) $\mathrm{Pt} / \mathrm{CeO}_{2}$ during the steam reforming of $\mathrm{AcOH}$ in the presence (above) and absence (below) of oxygen.

\subsection{Discussion}

One of the main issues in the production of $\mathrm{H}_{2}$ via steam reforming of pyrolysis oil-based components is the development of a stable catalyst [8, 19]. In this work, the stability of platinum-based catalysts for steam reforming of $\mathrm{AcOH}$, a model component in pyrolysis oil, has been studied in detail. A close look at the catalytic results (Figs. 3.5-3.7) shows that platinum-based catalysts presented very high activity, with complete conversion of $\mathrm{AcOH}$ at high space velocity and initial TOS. We have shown earlier that a bi-functional mechanism is operative for platinum-based catalysts in steam reforming of acetic acid $[6,7,20]$. Acetic acid decomposes over Pt to result in sorbed $\mathrm{CH}_{\mathrm{x}}$ specie [20] which are reformed by hydroxyl groups generated on the support oxide in the presence of water. Reasonable amounts of $\mathrm{H}_{2}$ were observed over $\mathrm{ZrO}_{2}$ (Fig. 3.4a) and $\mathrm{CeO}_{2}$ (Fig. 3.6a) suggesting that these supports have some steam reforming activity. Comparable observations were reported by Basagiannis et al. [21] for the steam reforming of $\mathrm{AcOH}$ over $\mathrm{Al}_{2} \mathrm{O}_{3}$ type materials at similar reaction conditions.

Unfortunately, the support oxide $\left(\mathrm{ZrO}_{2}\right.$ or $\left.\mathrm{CeO}_{2}\right)$ also catalyses two undesirable reactions of $\mathrm{AcOH}$ : (i) decomposition to $\mathrm{CO}_{2}$ and $\mathrm{CH}_{4}$ and (ii) condensation, namely 
ketonization, to produce acetone. Both routes have been reported earlier over metal oxide materials [22-24] in line with our results (Figs. 3.4a and 3.6a).

The presence of $\mathrm{Pt}$ clearly enhanced steam reforming and water-gas shift reactions, as evidenced by an initial product composition near thermodynamic equilibrium (Figs. 3.5a and 3.7a). The low amounts of $\mathrm{CH}_{4}$ observed over $\mathrm{Pt} / \mathrm{ZrO}_{2}$ and $\mathrm{Pt} / \mathrm{CeO}_{2}$ as compared to those over the corresponding supports could be explained by the fact that platinum-based catalysts are excellent for the steam reforming of methane [25]. Rioche et al. [26] carried out steam reforming of $\mathrm{AcOH}$ over 1wt.\% Pt/CeZrO 2 around $700{ }^{\circ} \mathrm{C}$ with $\mathrm{S} / \mathrm{C}$ ratio of 2 . They observed a $\mathrm{H}_{2} / \mathrm{CO}$ ratio lower than in our case. $\mathrm{CO}$ concentration normally decreases when increasing the $\mathrm{S} / \mathrm{C}$ ratio at a given temperature. The lower $\mathrm{S} / \mathrm{C}$ ratios in their study can explain the differences observed.

The use of $\mathrm{ZrO}_{2}$ as a support (Fig. 3.4a) did not result in stable catalyst activity under our conditions. Acetone appeared as a product during deactivation and disappeared again when the reactor system reached levels of gas phase homogeneous reactions. It is known that $\mathrm{ZrO}_{2}$ is active in the ketonization of $\mathrm{AcOH}$ to lead to acetone $[23,24]$. Acetone exhibits high chemical reactivity on metal oxides, and further condensation reactions (C-C bond coupling) cannot be suppressed. This yields to oligomeric non-volatile specie that then result in deactivation of the catalyst [22, 27, 28]. Scheme 3.1 shows reaction routes during steam reforming of acetic acid and formation/consumption of acetone.

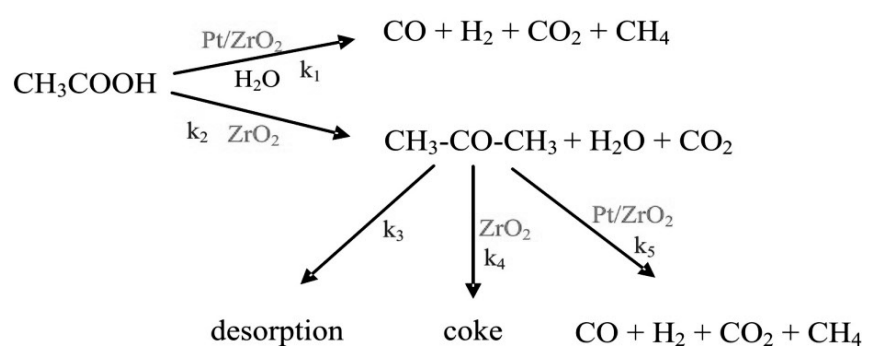

Scheme 3.1. Reaction scheme of the catalytic steam reforming of acetic acid over $\mathrm{Pt} / \mathrm{ZrO}_{2}$. For details of coking $\left(\mathrm{k}_{4}\right)$ see Scheme 3.2 .

Over a fresh catalyst, steam reforming of acetone $\left(\mathrm{k}_{5}\right)$ is significant, as seen from experiments using acetone as feed (Fig. 3.8a). Parallel, acetone formed is also converted to oligomeric coke specie $\left(\mathrm{k}_{4}\right)$. Thus, the absence of acetone in the 
beginning of the reaction suggests that the routes for the disappearance of acetone, i.e. condensation reactions and/or steam reforming (routes 4 and 5 respectively) are faster than its formation (route 2). We reported earlier [7] that the active sites for the steam reforming of $\mathrm{AcOH}$ over $\mathrm{Pt} / \mathrm{ZrO}_{2}$ are the boundaries between the metal and the support. As soon as the coke blocks those areas, the routes associated with steam reforming $\left(\mathrm{k}_{1}\right.$ and $\left.\mathrm{k}_{5}\right)$ are suppressed. Acetone is then observed in the gas phase $\left(\mathrm{k}_{3}\right)$. Part of the support is still available to convert $\mathrm{AcOH}$ to acetone (route 2) and further to coke. At a certain instant, however, this will block all support sites in such way that $\mathrm{AcOH}$ will not be further converted catalytically and no acetone will be formed. Only gas phase (non catalytic) reactions will occur at this stage. After catalyst deactivation we indeed observed only gas phase contribution into acetic acid conversion (Figs. 3.5a and 3.7a).

Under comparable conditions $\left(750{ }^{\circ} \mathrm{C}, \mathrm{S} / \mathrm{C}\right.$ ratio 3), Vagia et al. [29] reported $23 \%$ thermal cracking conversion of $\mathrm{AcOH}$, in line with our findings (Fig. 3.3a). However they observed higher amounts of $\mathrm{H}_{2}$ and $\mathrm{CH}_{4}$ and they did not report formation of undetectable gases. At high temperatures and in the absence of catalyst, formation of tars is very likely. These compounds are volatile at these high temperatures; however they condense below 350-400 ${ }^{\circ} \mathrm{C}$. Indeed, exit of the reactor showed accumulation of some black deposits, indicating that oligomer/condensate formation occurred in our case. This led to poor " $\mathrm{C}$ " balance $(\sim 85 \%)$. Other authors $[30,31]$ have shown very high or even complete conversion of $\mathrm{AcOH}$ at $700{ }^{\circ} \mathrm{C}$ in the absence of catalyst. These results indicate that thermal decomposition depends on a variety of factors such as temperature, steam to carbon ratio, contact time, void volume, etc and thus an exact comparison is not straightforward.

The stability of ceria-based catalysts is certainly improved as compared to $\mathrm{Pt} / \mathrm{ZrO}_{2}$ (Figs. 3.5a and 3.7a). Interestingly, acetone was also observed in the case of $\mathrm{Pt} / \mathrm{CeO}_{2}$, but only in traces (Fig. 3.7a). According to Scheme 3.1, this would imply that (i) $\mathrm{Pt} / \mathrm{CeO}_{2}$ is able to steam reform acetone much better than $\mathrm{Pt} / \mathrm{ZrO}_{2}\left(\mathrm{k}_{5}\right)$; (ii) the route for acetone condensation to lead to coke deposits is less significant $\left(\mathrm{k}_{4}\right)$. Our results on the steam reforming of acetone (Figs. 3.8a and 3.8b) support the first argument. In this way $\mathrm{Pt} / \mathrm{CeO}_{2}$ is indirectly minimizing the formation of carbonaceous 
deposits. At the same time we cannot rule out the possibility that less acetone is formed over $\mathrm{CeO}_{2}\left(\mathrm{k}_{2}\right)$.

The combination of the red-ox properties of $\mathrm{CeO}_{2}$ (Fig. 3.1) along with the potential of $\mathrm{H}_{2} \mathrm{O}$ to re-oxidize $\mathrm{CeO}_{2}$, as demonstrated by TPR/TPO experiments in Fig. 3.2, is a possible reason to explain that coke deposition is less significant. It is of general knowledge that $\mathrm{CeO}_{2}$ has excellent oxygen exchange capacity involving red-ox changes between $\mathrm{Ce}^{4+}$ and $\mathrm{Ce}^{3+}$ [32]. We thus propose that $\mathrm{CeO}_{2}$ is able to supply oxygen in order to combust coke deposits resulting in oxygen vacancies. Dissociation of $\mathrm{H}_{2} \mathrm{O}$ leads to the regeneration of the oxygen vacancies. Thus, accumulation of coke deposits on the catalyst surface is minimized.

Oxygen addition to the steam reforming feed improved the stability of nearly all systems, as evidenced by the changes in TOS (Figs. 3.4-3.7). Others have reported such improvements in catalyst stability. Cavallaro et al. [9] also observed a positive effect of oxygen addition on the stability of nobel metal based catalysts $\left(\mathrm{Rh} / \mathrm{Al}_{2} \mathrm{O}_{3}\right)$ in the steam reforming of ethanol at $650{ }^{\circ} \mathrm{C}$. The decrease in $\mathrm{H}_{2}$ yield due to the presence of oxygen is in agreement with literature. Vagia et al. [33] reported a decrease in $\mathrm{H}_{2}$ yield around $19 \%$ based on thermodynamic calculations on the autothermal steam reforming of $\mathrm{AcOH}$ at the same conditions used in this investigation, i.e. $700{ }^{\circ} \mathrm{C}$ and a $\mathrm{O}_{2} / \mathrm{AcOH}$ ratio of 0.4 .

Even though the presence of oxygen improved the catalyst lifetimes, $\mathrm{Pt} / \mathrm{ZrO}_{2}$ still suffered from rapid deactivation after 3 hours TOS (Fig. 3.5b). The profile was similar to that observed in the absence of oxygen (Fig. 3.5a). Acetone was observed in a comparable trend, suggesting that the mechanism of deactivation is the same. In the presence of oxygen, no acetone was observed in the case of $\mathrm{Pt} / \mathrm{CeO}_{2}$ (Fig. 3.7b); as expected it showed excellent stability for the steam reforming of acetic acid. Furthermore, in the presence of oxygen, the decrease in hydrogen yield was limited $\left(\mathrm{H}_{2}\right.$ yield decreased from 85 to $\left.75 \%\right)$ and coke was combusted to a larger extent. $\mathrm{Pt} / \mathrm{CeO}_{2}$ is thus a promising catalyst for the steam reforming of biomass-based oxygenates.

Enhanced stability of the spent catalysts is directly related to the lower extent of coking in the presence of oxygen (Table 3.2). Accordingly, the least amount of coke 
was observed on $\mathrm{Pt} / \mathrm{CeO}_{2}$, which was also the most stable. Evidences for a decrease in coke deposition in the steam reforming of oxygenates (ethanol) in the presence of oxygen have been reported in previous papers [9, 34]. The authors proposed a mechanism of auto-cleaning (in-situ coke combustion) of the catalytic surface by the oxygen, which is also relevant in our case.

It is relevant at this point to understand if there are differences in the chemical characteristics of coke for the different catalyst systems studied and if correlations can be drawn as to their stability. As mentioned earlier, during steam reforming, coke mostly results from a cascade of condensation and oligomerization reactions over the support $[6,21,22,27,35]$. Scheme 3.2 summarizes these reactions.

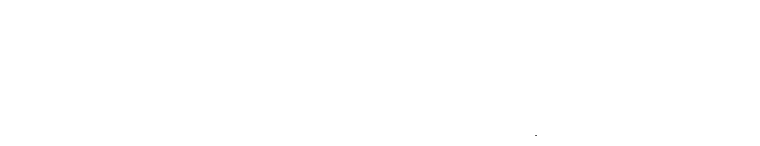

Scheme 3.2. Reactions scheme of formation of polyaromatics over metal oxide ( $k_{4}$ from Scheme 3.1).

MALDI-TOF MS spectra of coke from both $\mathrm{Pt} / \mathrm{ZrO}_{2}$ (Fig. 3.9a) and $\mathrm{Pt} / \mathrm{CeO}_{2}$ (Fig. 3.9b) catalysts clearly show that under oxidative conditions, oligomerization/ageing occur to a lower extent since the spectra are dominated by lower molecular weight specie. This might be due to the fact that continuous in-situ combustion of coke/coke precursors keeps their levels lower. Lower molecular weight coke specie are expected to be more reactive and can be gasified more easily by oxygen.

To summarize, $\mathrm{Pt} / \mathrm{ZrO}_{2}$ catalyst improved stability with the presence of oxygen (compare Figs. 3.5a and 3.5b). However, deactivation also occurred after longer TOS (Fig. 3.5b). On the other hand, $\mathrm{Pt} / \mathrm{CeO}_{2}$, catalyst with red-ox capability, showed excellent stability under oxidative conditions (Fig. 3.7b). Furthermore, $\mathrm{Pt} / \mathrm{CeO}_{2}$ enhanced steam reforming of coke precursors, acetone in our case (Fig. 3.8b). Therefore we propose that the combination of (i) enhanced steam reforming activity of acetone (coke precursor), (ii) oxygen addition to the steam reforming feed and the (iii) red-ox characteristics of $\mathrm{CeO}_{2}$ to use both oxygen and water as oxidants, are the key reasons to justify the excellent catalytic stability of $\mathrm{Pt} / \mathrm{CeO}_{2}$. This catalyst shows 
promise for the steam gasification of more complex biomass-derived oxygenates that are currently under study.

\subsection{Conclusions}

Our findings demonstrate that the nature of the support has a strong influence on the catalyst stability in the steam reforming of $\mathrm{AcOH}$. Using a catalyst support with red-ox properties improves catalyst lifetime. Enhanced steam reforming of acetone, a coke precursor, and minimization of carbonaceous specie formed are reasons for extended catalyst life. Catalyst stability can be further improved by the addition of oxygen in the feed to allow in-situ combustion of coke formed. Presence of oxygen also minimizes the extent of oligomerization/ageing leading to coke specie more reactive to gasification. The enhanced steam reforming activity and red-ox characteristics that allow the use of water as an oxidant for coke combustion/gasification make $\mathrm{Pt} / \mathrm{CeO}_{2}$ a promising catalyst for the steam reforming of biomass-based oxygenates. 


\section{References}

[1] M. Balat, Energy Sources A: Recovery, Utilization, and Environmental Effects 30 (2008) 552 - 564.

[2] G.Q. Lu, J.C. Diniz da Costa, M. Duke, S. Giessler, R. Socolow, R.H. Williams, and T. Kreutz, Journal of Colloid and Interface Science 314 (2007) 589-603.

[3] C.A. Mullen, and A.A. Boateng, Energy and Fuels (2008) 2104-2109.

[4] F.J.P. Diebold. A review of the toxicity of biomass pyrolysis liquids formed at low temperatures. Fast Pyrolysis of Biomass: A Handbook, Newbury, UK, 2003, pp. 135-163.

[5] F.A. T. Milne, M. Davis, S. Deutch, D. Johnson. 1997. Developments in Thermochemical Biomass Conversion, London, 1997, pp. 409-424.

[6] K. Takanabe, K. Aika, K. Seshan, and L. Lefferts, Journal of Catalysis 227 (2004) 101-108.

[7] K. Takanabe, K.-i. Aika, K. Inazu, T. Baba, K. Seshan, and L. Lefferts, Journal of Catalysis 243 (2006) 263-269.

[8] K. Takanabe, K.-i. Aika, K. Seshan, and L. Lefferts, Chemical Engineering Journal 120 (2006) 133-137.

[9] S. Cavallaro, V. Chiodo, S. Freni, N. Mondello, and F. Frusteri, Applied Catalysis A: General 249 (2003) 119-128.

[10] S.M. de Lima, I.O. da Cruz, G. Jacobs, B.H. Davis, L.V. Mattos, and F.B. Noronha, Journal of Catalysis 257 (2008) 356-368.

[11] D. Haffad, A. Chambellan, and J.C. Lavalley, Journal of Molecular Catalysis A: Chemical 168 (2001) 153-164.

[12] F. Sadi, D. Duprez, F. Gérard, and A. Miloudi, Journal of Catalysis 213 (2003) 226-234.

[13] G. Vlaic, R. Di Monte, P. Fornasiero, E. Fonda, J. Kaspar, and M. Graziani, Journal of Catalysis 182 (1999) 378-389.

[14] M.H. Yao, R.J. Baird, F.W. Kunz, and T.E. Hoost, Journal of Catalysis 166 (1997) 67-74.

[15] C. Sievers, I. Zuazo, A. Guzman, R. Olindo, H. Syska, and J.A. Lercher, Journal of Catalysis 246 (2007) 315-324.

[16] M. Boaro, M. Vicario, C. de Leitenburg, G. Dolcetti, and A. Trovarelli, Catalysis Today 77 (2003) 407-417.

[17] T. Caputo, L. Lisi, R. Pirone, and G. Russo, Applied Catalysis A: General 348 (2008) 42-53. 
[18] C.d. Leitenburg, A. Trovarelli, and J. Kaspar, Journal of Catalysis 166 (1997) 98-107.

[19] B. Matas Güell, I. M. Torres da Silva, K. Seshan, and L. Lefferts, Applied Catalysis B: 88 (2009) 59-65.

[20] B. Matas Güell, I. Babich, K. Seshan, and L. Lefferts, Journal of Catalysis 257 (2008) 229-231.

[21] A.C. Basagiannis, and X.E. Verykios, Applied Catalysis B: Environmental 82 (2008) 77-88.

[22] S. Lippert, W. Baumann, and K. Thomke, Journal of Molecular Catalysis 69 (1991) 199-214.

[23] M. Gliński, and J. Kijeński, Reaction Kinetics and Catalysis Letters 69 (2000) 123-128.

[24] K. Parida, and H.K. Mishra, Journal of Molecular Catalysis A: Chemical 139 (1999) 73-80.

[25] J.R. Rostrup-Nielsen, Catalysis: Science and Technology 5 (1984) 1-117.

[26] C. Rioche, S. Kulkarni, F.C. Meunier, J.P. Breen, and R. Burch, Applied Catalysis B: Environmental 61 (2005) 130-139.

[27] M.A. Aramendía, V. Borau, C. Jiménez, A. Marinas, J.M. Marinas, J.R. Ruiz, and F.J. Urbano, Journal of Molecular Catalysis A: Chemical 218 (2004) 81-90.

[28] L.M. Gandía, M.A. Vicente, and A. Gil, Applied Catalysis B: Environmental 38 (2002) 295-307.

[29] E.C. Vagia, and A.A. Lemonidou, Applied Catalysis A: General 351 (2008) 111-121.

[30] J.R. Galdamez, L. Garcia, and R. Bilbao, Energy Fuels 19 (2005) 1133-1142.

[31] D. Wang, D. Montane, and E. Chornet, Applied Catalysis A: General 143 (1996) 245-270.

[32] K. Nagaoka, K. Seshan, K. Takanabe, and K.-i. Aika, Catalysis Letters 99 (2005) 97-100.

[33] E.C. Vagia, and A.A. Lemonidou, International Journal of Hydrogen Energy 33 (2008) 2489-2500.

[34] S. Cavallaro, V. Chiodo, A. Vita, and S. Freni, Journal of Power Sources 123 (2003) 10-16.

[35] K.M. Dooley, A.K. Bhat, C.P. Plaisance, and A.D. Roy, Applied Catalysis A: General 320 (2007) 122-133. 


\section{Chapter 4}

\section{Steam reforming of acetic acid- Influence of lanthanum and potassium on nickel-based catalysts}

Steam reforming of acetic acid, a biomass derived oxygenate, has been studied over nickel-based catalysts. $\mathrm{Ni} / \mathrm{ZrO}_{2}$ showed gradual deactivation in time. Coke formation as well as a competitive adsorption of reactants is suggested to be responsible for the catalyst deactivation. Addition of potassium strongly influences the reduction temperature of $\mathrm{NiO}$. The presence of potassium and lanthanum improves catalyst stability by decreasing coke accumulation. It is proposed that the presence of lanthanum as an oxy-carbonate phase enhances coke gasification. 



\subsection{Introduction}

Environmental friendly energy is a major goal in our society [1]. Over the past few years, hydrogen has aroused tremendous interest as an energy carrier. Currently, one of the limitations of hydrogen generation is that it is based on fossil fuels, leading to a net production of greenhouse gases [2]. Thus, the use of biomass as an alternative hydrogen source, with $\mathrm{CO}_{2}$-neutral impact, may become important in the future.

Solid biomass can be converted into a liquid pyrolysis oil, via the so called flash pyrolysis process, a convenient feedstock for further processing. This also makes storage and transport of biomass-based feedstocks more effective. Gasification of pyrolysis oil is a promising route for syngas $\left(\mathrm{CO}+\mathrm{H}_{2}\right)$ generation from biomass. However, it is energy intensive and requires temperatures around $1250{ }^{\circ} \mathrm{C}$ [3]. Milder conditions can be applied in the presence of a catalyst $\left(750-900{ }^{\circ} \mathrm{C}\right)$ [4]. Dolomite, alkali metal and nickel-based catalysts are the most common catalysts reported for gasification of biomass [5]. However, severe coking and deactivation is a major problem for both biomass and pyrolysis oil gasification [3-6]. Design of a stable catalyst is still an open challenge.

In previous studies on the steam reforming of biomass related oxygenates, particularly acetic acid $(\mathrm{AcOH})$, we have reported that supported platinum catalysts show excellent activity [6,7]. However, condensation of intermediate oxygenates formed (e.g. acetone), during reaction, on the support leads to oligomers and coke formation. These species block the catalytic active sites, resulting in deactivation [7]. Such polymerization cannot be avoided [6] and the strategy to overcome catalyst deactivation is to minimize such oligomers and coke accumulation. Regeneration of the catalyst periodically, is one option. In this case, the oligomers/coke accumulated on the catalyst are combusted in air. This results in discontinuous operation as the reaction is stopped during the regeneration step and therefore catalyst lifetime, reported currently [7], is too short to do this on a commercial scale. Another possible approach is to remove coke as it is formed, by in-situ regeneration (combustion) during reaction, similar to autothermal reforming, or by enhancing the steam reforming activity, thus minimizing coke/oligomer accumulation. In our case, the approach was chosen (i) to limit coke accumulation during steam reforming of acetic 
acid by enhancing the steam reforming activity and (ii) attempting to steam reform the relatively unreactive deposits such as oligomers.

In an earlier study [8] a bifunctional mechanism has been proposed for $\mathrm{Pt} / \mathrm{ZrO}_{2}$ catalyst, where both platinum and support participate in the acetic acid $(\mathrm{AcOH})$ to syngas conversion. $\mathrm{AcOH}$ is suggested to be activated on platinum and water is activated on $\mathrm{ZrO}_{2}$. Water activation is the demanding step; enhancement of water sorption/activation is essential in order to increase the steam reforming activity. It is known [9, 10] that nickel, in contrast to platinum, is able to activate $\mathrm{H}_{2} \mathrm{O}$ via formation of nickel oxide. $\mathrm{Ni} / \mathrm{ZrO}_{2}$ was selected for this study with the basis that both nickel and zirconia can contribute to water activation during steam reforming.

In general, stability of nickel-based catalysts is hindered by coke formation, sometimes including carbon-nano-fibers, as well as sintering of the metal particles during reaction [11]. Marquevich et al. [12] studied the steam reforming of sunflower oil over $\mathrm{Ni} / \mathrm{Al}$ catalysts between 550 and $650^{\circ} \mathrm{C}$. Nickel particle size increased by a factor of 4 after 12 hours time on stream, causing catalyst deactivation. On the other hand, Kechagiopoulos et al. [13] reported deactivation due to coke deposition during steam reforming of biomass-based oxygenates over nickel-based catalysts at similar temperatures $\left(600\right.$ to $\left.750{ }^{\circ} \mathrm{C}\right)$. An exhaustive review on the gasification of biomass and related feedstock's, including nickel-based catalysts, has been presented by Ross et al. [5].

There is tremendous amount of information available on the design of effective nickel-based catalysts for steam reforming of methane [14, 15]. Modification with alkali/alkaline earth metals (eg, $\mathrm{K}, \mathrm{Na}, \mathrm{Ca}$ ) and rare earths $(\mathrm{La})$ is reported to result in enhanced activity and stability [5, 14, 15]. Alkali metals are suggested to enhance gasification activity by assisting in the formation of $\mathrm{OH}$ groups on oxide supports $[10,14,16]$. In our case, therefore, addition of potassium to $\mathrm{Ni} / \mathrm{ZrO}_{2}$ may improve catalyst stability by gasifying carbonaceous species deposited on the catalyst surface. It is further suggested that, in the case of dry reforming of $\mathrm{CH}_{4}$, lanthanum forms oxygen-containing species $\left(\mathrm{La}_{2} \mathrm{O}_{2} \mathrm{CO}_{3}\right)$ during reaction which help combusting coke accumulated on the catalyst $[17,18]$. Lanthanum is also known to stabilize metal particles and oxides by preventing sintering $[19,20]$. 
Despite this extensive research on the modification of nickel-based catalysts for steam reforming of alkanes, very little work has been reported concerning steam reforming of biomass-based oxygenates, e.g., acetic acid [21, 22]. Basagiannis et al. [21] studied the influence of reaction temperature and catalytic material on acetic acid steam reforming over nickel supported on $\mathrm{La}_{2} \mathrm{O}_{3}$ and/or $\mathrm{Al}_{2} \mathrm{O}_{3}$. The role of lanthanum is, according to them, to form oxycarbonate type species $\left(\mathrm{La}_{2} \mathrm{O}_{2} \mathrm{CO}_{3}\right)$ which helps minimizing coke accumulation, as mentioned earlier. However, no results on the stability of the catalysts are shown. Román Galdámez et al. [22] also studied the influence of lanthanum on the catalytic and mechanical properties of $\mathrm{Ni} / \mathrm{Al}_{2} \mathrm{O}_{3}$ catalysts. They did not observe any improvement on hydrogen yields by the presence of lanthanum.

Aim of this investigation is to explore the effect of lanthanum and potassium promoters on the activity and stability of $\mathrm{Ni} / \mathrm{ZrO}_{2}$ for the steam reforming of acetic acid. Development of a stable catalyst for the steam reforming of acetic acid as a model component is a first step towards stable catalysts for the steam reforming of flash pyrolysis oil.

\subsection{Experimental}

\subsubsection{Catalyst preparation}

$\mathrm{ZrO}_{2}$ (monoclinic, Daiichi Kigenso Kagaku Kogio, RC 100) was first calcined for $15 \mathrm{~h}$ at $850^{\circ} \mathrm{C}$ (heating rate $\left.5^{\circ} \mathrm{C} \cdot \mathrm{min}^{-1}\right)$ in flowing air $\left(30 \mathrm{ml} \cdot \mathrm{min}^{-1}\right)$. It was then crushed and sieved to give grains of 0.3-0.6 mm. The grains were impregnated with $0.1 \mathrm{M} \mathrm{Ni}\left(\mathrm{NO}_{3}\right)_{2} \cdot 6 \mathrm{H}_{2} \mathrm{O}$ (Alfa Aesar) solution to load $\mathrm{ZrO}_{2}$ with 3.5 wt.\% Ni. The catalyst was dried at $70^{\circ} \mathrm{C}$ for $4 \mathrm{~h}$ in a rotary evaporator followed by drying overnight at $120{ }^{\circ} \mathrm{C}$ and, eventually, calcined at $725{ }^{\circ} \mathrm{C}$ for $15 \mathrm{~h}$ (heating rate $5{ }^{\circ} \mathrm{C} \cdot \mathrm{min}^{-1}$ ) in flowing air $\left(30 \mathrm{ml} \cdot \mathrm{min}^{-1}\right)$. Hereafter, this catalyst is denoted as $\mathrm{Ni} / \mathrm{ZrO}_{2}$.

$\mathrm{K}$ and $\mathrm{La}$ doped catalysts, 3.5wt.\%Ni/2\%K-ZrO 2 , 3.5wt.\%Ni/5wt.\%La-ZrO and $3.5 \mathrm{wt} . \% \mathrm{Ni} / 2 \mathrm{wt} . \% \mathrm{~K}-5 \mathrm{wt} . \% \mathrm{La}-\mathrm{ZrO}_{2}$, were also prepared via wet impregnation. $\mathrm{K}$ and $\mathrm{La}$ were added to $\mathrm{ZrO}_{2}$ by using $\mathrm{KNO}_{3}$ and $\mathrm{La}\left(\mathrm{NO}_{3}\right)_{3} \cdot 6 \mathrm{H}_{2} \mathrm{O}$ solutions, respectively. After impregnation, the supports were dried using a rotary evaporator followed by drying overnight at $120^{\circ} \mathrm{C}$. Once dried, the doped supports were first 
calcined at $600{ }^{\circ} \mathrm{C}$ for $4 \mathrm{~h}$ and then loaded with $3.5 \mathrm{wt} . \% \mathrm{Ni}$. All three catalysts were finally calcined for $15 \mathrm{~h}$ at $725{ }^{\circ} \mathrm{C}$. Hereafter, these catalysts are denoted as $\mathrm{Ni} / \mathrm{K}-\mathrm{ZrO}_{2}, \mathrm{Ni} / \mathrm{La}-\mathrm{ZrO}_{2}$ and $\mathrm{Ni} / \mathrm{K}-\mathrm{La}-\mathrm{ZrO}_{2}$.

\subsubsection{Catalyst characterization}

The elemental composition of the catalysts was determined with X-ray fluorescence spectroscopy (XRF) (Phillips PW 1480 spectrometer). Specific surface area measurements were carried out with $\mathrm{N}_{2}$ adsorption-desorption at $77 \mathrm{~K}$ in a Micromeritics TriStar instrument, applying the BET adsorption isotherm.

Nickel particle size was determined with two different techniques: X-rays diffraction (XRD) and Scanning Transmission Electron Microscopy - Energy Dispersive X-Ray analysis / Electron Energy Loss Spectroscopy (STEM-EDX/EELS). XRD patterns were recorded with a Philips X'Pert APD using $\mathrm{Cu} K \alpha$ radiation. Spectra were registered with $2 \theta$ between 5 and $80^{\circ}$. The mean nickel particle diameter was estimated by X-Ray line broadening analysis (XLBA) using the Scherrer equation.

Catalyst reducibility was probed with a home made temperature-programmed reduction (TPR) equipped with a standard thermoconductivity detector. For this purpose, $300 \mathrm{mg}$ of catalyst sample was pretreated in $\mathrm{Ar}$ at $700{ }^{\circ} \mathrm{C}$ for $5 \mathrm{~min}$. After pretreatment, the sample was first cooled down to room temperature in Ar and then heated to $800{ }^{\circ} \mathrm{C}$ at a rate of $5{ }^{\circ} \mathrm{C} \cdot \mathrm{min}^{-1}$ in a $5 \% \mathrm{H}_{2} / \mathrm{Ar}$ flow $\left(30 \mathrm{ml} \cdot \mathrm{min}^{-1}\right)$.

Thermogravimetry (TG, Mettler Toledo) was used to quantify the amount of carbon deposited on the catalysts after reaction. The samples were heated from room temperature to $800{ }^{\circ} \mathrm{C}$ at $5{ }^{\circ} \mathrm{C} \cdot \mathrm{min}^{-1}$ in air.

\subsubsection{Catalytic testing}

For catalytic experiments, $50 \mathrm{mg}$ of catalyst diluted with quartz particles with grains of $0.3-0.6 \mathrm{~mm}$ (ratio 1:1) was loaded in an alumina fixed-bed reactor (4mm i.d.) and held in place by quartz wool plugs. The catalyst was first reduced in-situ in $5 \% \mathrm{H}_{2} / \mathrm{N}_{2}$ flow $\left(50 \mathrm{ml} \cdot \mathrm{min}^{-1}\right)$ at $650{ }^{\circ} \mathrm{C}$ for $1 \mathrm{~h}$. After purging with $\mathrm{N}_{2}$ for $15 \mathrm{~min}$, the temperature was increased to $700{ }^{\circ} \mathrm{C}$. An aqueous solution of acetic acid with a steam to carbon molar ratio $(\mathrm{S} / \mathrm{C})$ of 5 was delivered by means of a pulse-free 
syringe pump (Isco Model 500 D). This solution was evaporated at $190{ }^{\circ} \mathrm{C}$ and provided to the system via a preheater (cylinder, i.d. $50 \mathrm{~mm}$, length $150 \mathrm{~mm}$, packed with quartz wool). The mixture was diluted with nitrogen, which was used both as inert carrier gas and as internal standard. The gas feed, consisting of $2.5 \% \mathrm{CH}_{3} \mathrm{COOH}$ $\left(3 \mathrm{ml} \cdot \mathrm{min}^{-1}\right) / 25 \% \mathrm{H}_{2} \mathrm{O}\left(30 \mathrm{ml} \cdot \mathrm{min}^{-1}\right) /$ balance $\mathrm{N}_{2}$, was introduced to the fixed-bed reactor. The total gas hourly space velocity (GHSV) was calculated on a volume basis.

The composition of the reactant/product mixture was determined with an on-line gas chromatograph (GC, Varian CP-3800) equipped with (i) two thermal conductivity detectors (TCD), for the quantification of permanent gases, and a flame ionization detector (FID) for quantification of the hydrocarbons and (ii) the following columns for separation: Hayesep Q, Hayesep T, Molsieve 13X, Molsieve 5A and CP-Wax $52 \mathrm{CB}$.

Acetic acid conversion was calculated as the moles of acetic acid reacted divided by the moles of acetic acid fed.

The hydrogen yield was defined as the percentage of the maximum amount of hydrogen that can be produced, based on the following reaction:

$$
\mathrm{CH}_{3} \mathrm{COOH}+2 \mathrm{H}_{2} \mathrm{O} \rightarrow 2 \mathrm{CO}_{2}+4 \mathrm{H}_{2}
$$

For carbon-containing compounds, the yields were calculated based on $\mathrm{C}_{1}$ equivalent values; e.g., $\mathrm{CO}$ and $\mathrm{CO}_{2}$ yields were calculated as one time the number of moles produced divided by two times the number moles of acetic acid fed.

\subsection{Results}

\subsubsection{Catalyst characterization}

Elemental analysis and the specific surface area of the nickel-based catalysts are shown in Table 4.1. In general, nickel loadings were in the range intended for preparation $(3.5 \%)$. In the case of potassium, only about $50 \%$ of the intended amount was retained in the catalyst. Lanthanum amounts were as expected. Lanthanum addition did not significantly influence the total surface area of the catalysts, whereas potassium addition caused a slight decrease. Table 4.2 compares mean nickel oxide 
particle sizes as obtained from XRD-XLBA measurements. Only minor differences in the mean particle size were observed. STEM-EDX/EELS measurements (not shown) confirmed the order of magnitude of the size of the nickel oxide particles.

Table 4.1. Catalysts elemental analysis and BET surface area of fresh samples.

\begin{tabular}{lcccc}
\hline \multirow{2}{*}{ Catalyst } & \multicolumn{3}{c}{ Content (wt.\%) } & Surface area $\left(\mathrm{m}^{2} \cdot \mathrm{g}^{-1}\right)$ \\
\cline { 2 - 4 } & $\mathrm{Ni}$ & $\mathrm{La}$ & $\mathrm{K}$ & \\
\hline $\mathrm{Ni} / \mathrm{ZrO}_{2}$ & 3.65 & - & - & 35 \\
$\mathrm{Ni} / \mathrm{La}-\mathrm{ZrO}{ }_{2}$ & 3.44 & 4.27 & - & 33 \\
$\mathrm{Ni} / \mathrm{K}-\mathrm{ZrO}_{2}$ & 3.16 & - & 1.07 & 27 \\
$\mathrm{Ni} / \mathrm{K}-\mathrm{La}-\mathrm{ZrO}_{2}$ & 3.36 & 4.29 & 0.90 & 25 \\
\hline
\end{tabular}

Table 4.2. Mean nickel oxide particle size calculated by XRD for catalysts before and after reaction.

\begin{tabular}{lcc}
\hline \multirow{2}{*}{ Catalyst } & \multicolumn{2}{c}{ Crystallite diameter (nm) } \\
\cline { 2 - 3 } & Before reaction & After reaction \\
\hline $\mathrm{Ni} / \mathrm{ZrO}_{2}$ & 20 & 21 \\
$\mathrm{Ni} / \mathrm{La}-\mathrm{ZrO}{ }_{2}$ & 22 & 16 \\
$\mathrm{Ni} / \mathrm{K}-\mathrm{ZrO}{ }_{2}$ & 20 & 10 \\
$\mathrm{Ni} / \mathrm{K}-\mathrm{La}-\mathrm{ZrO}_{2}$ & 16 & 15 \\
\hline
\end{tabular}

Experimental results of hydrogen consumption during TPR of the Ni-based catalysts are shown in Fig. 4.1. TPR profile of $\mathrm{Ni} / \mathrm{ZrO}_{2}$ (Fig. 4.1a) exhibited three reduction peaks with maxima at 190, 250 and $350{ }^{\circ} \mathrm{C}$, respectively. Addition of lanthanum (Fig. 4.1b) shifted all the peaks to higher temperatures. Potassium doping (Fig. 4.1c)

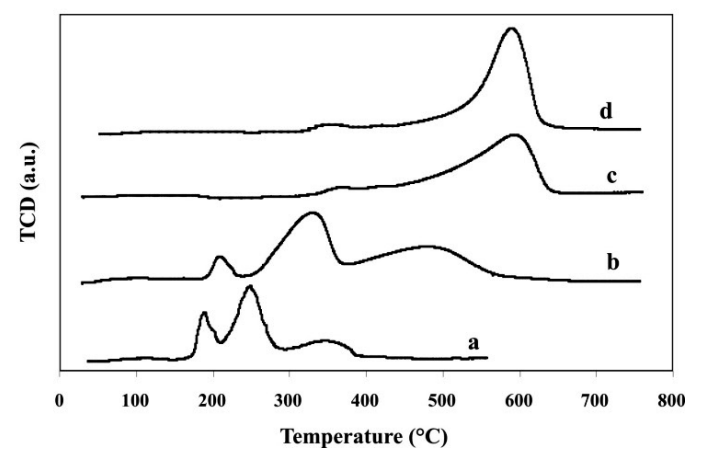

Fig. 4.1. $\mathrm{TPR}$ profiles for (a) $3.5 \% \mathrm{Ni} / \mathrm{ZrO}_{2}$, (b) $3.5 \% \mathrm{Ni} / \mathrm{LaZrO}_{2}$ (c) $3.5 \% \mathrm{Ni} / \mathrm{K}-\mathrm{ZrO}_{2}$, (d) $3.5 \% \mathrm{Ni} / \mathrm{K}-\mathrm{La}-$ $\mathrm{ZrO}_{2}$. 
resulted in a completely different reduction profile. A small broad peak centered around $370{ }^{\circ} \mathrm{C}$ and a larger, second peak at $595{ }^{\circ} \mathrm{C}$ were observed. The spectrum corresponding to the catalyst containing both potassium and lanthanum (Fig. 4.1d) displayed practically the same profile as the catalyst doped with potassium only. In both cases (Fig.4.1c and Fig. 4.1d) the main peak was shifted to much higher temperatures, as compared to catalysts without potassium (Fig. 4.1a and Fig. 4.1b). It is important to note that the total peak area corresponds well with the amount of $\mathrm{H}_{2}$ required for the reduction of nickel oxide to nickel in all catalysts.

\subsubsection{Catalyst testing}

The

performance of the $\mathrm{Ni} / \mathrm{ZrO}_{2}$-based catalysts in the steam reforming of acetic acid is compared in Fig. 4.2 and 4.3 in terms of $\mathrm{H}_{2}$ yield and acetic acid conversion, respectively. A commercial nickel-based pre-reforming catalyst was used as a reference. Regarding the hydrogen production, all Ni catalysts showed very high initial activity, with $\mathrm{H}_{2}$ yields close to thermodynamic equilibrium composition (87\%). The $\mathrm{Ni} / \mathrm{ZrO}_{2}$ catalyst deactivated the most, with $\mathrm{H}_{2}$ yields dropping from 87 to $62 \%$ during 22 h. Ni/K-Z $\mathrm{ZrO}_{2}$ showed slightly improved

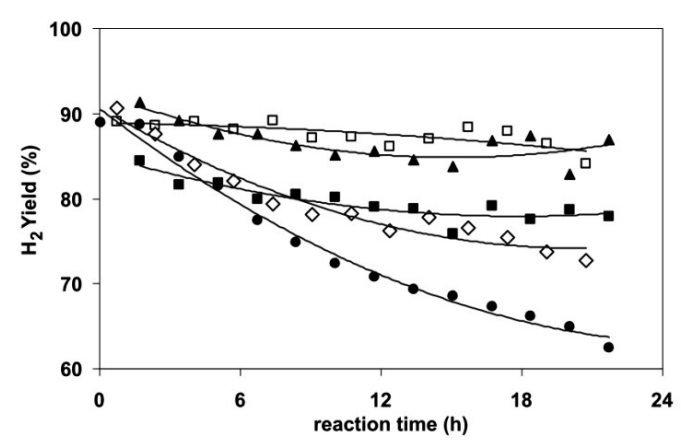

Fig. 4.2. $\mathrm{H}_{2}$ yield $v s$. time on stream for the stem reforming of $\mathrm{AcOH}$ over (•) $3.5 \% \mathrm{Ni} / \mathrm{ZrO}_{2},(\square) \quad 3.5 \% \mathrm{Ni} / \mathrm{La}-\mathrm{ZrO}_{2}(\diamond)$

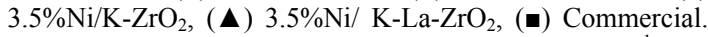
(reaction conditions: $700^{\circ} \mathrm{C}, \mathrm{S} / \mathrm{C}=5, \mathrm{GHSV}=240000 \mathrm{~h}^{-1}$ ).

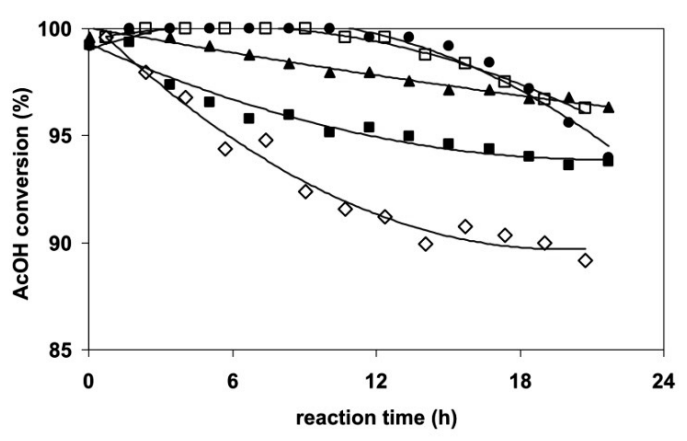

Fig. 4.3. AcOH conversion vs. time on stream for the stem reforming of $\mathrm{AcOH}$ over (•) $3.5 \% \mathrm{Ni} / \mathrm{ZrO}_{2}, \quad$ (口) $3.5 \% \mathrm{Ni} / \mathrm{La}-\mathrm{ZrO}_{2} \quad(\diamond) \quad 3.5 \% \mathrm{Ni} / \mathrm{K}-\mathrm{ZrO}_{2}, \quad(\boldsymbol{\Delta}) \quad 3.5 \% \mathrm{Ni} / \mathrm{K}-$ $\mathrm{LaZrO}_{2}$, (匹) Commercial. (reaction conditions: $700^{\circ} \mathrm{C}, \mathrm{S} / \mathrm{C}$ $=5$, GHSV $=240000 \mathrm{~h}^{-1}$ ). 
performance, but still deactivated with time. The two lanthanum promoted catalysts showed the best results. These catalysts were reasonably stable and lost only about $7 \% \mathrm{H}_{2}$ yield in $20 \mathrm{~h}$ time on stream. These catalysts were more active than the commercial catalyst, even after $20 \mathrm{~h}$ time on stream, and stabilities were comparable. Acetic acid conversions were, in all cases (Fig. 4.3), complete (close to 100\%) during the first minutes of reaction and decreased slowly with time on stream. Carbon balance was reasonable in all the experiments and was $100 \pm 5 \%$. Further, all catalysts showed a gradual increase in $\mathrm{CO}$ formation with time (Fig. 4.4), with a simultaneous decrease in $\mathrm{CO}_{2}$ yield (Fig. 4.5) and $\mathrm{H}_{2}$ yield (Fig. 4.2). This effect was especially pronounced in the case of the un-promoted catalyst. $\mathrm{CH}_{4}$ formation was negligible in all cases

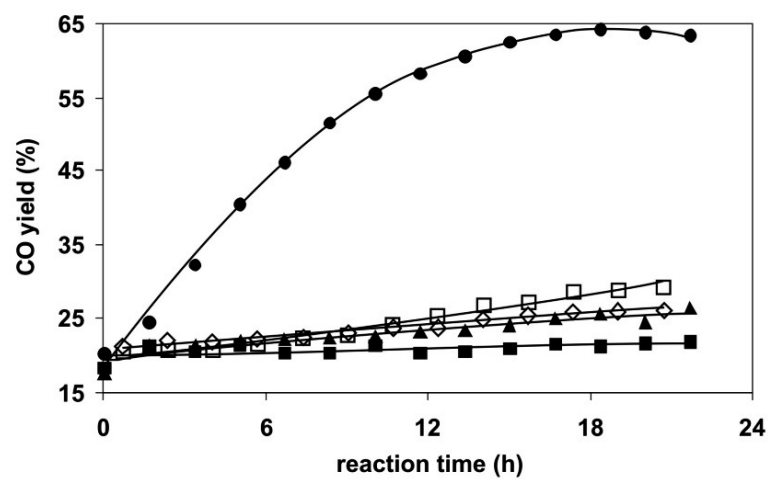

Fig. 4.4. $\mathrm{CO}$ yield $v s$. time on stream for the stem reforming of $\mathrm{AcOH}$ over $(\bullet) 3.5 \% \mathrm{Ni} / \mathrm{ZrO}_{2}$, ( $\square$ ) $3.5 \% \mathrm{Ni} / \mathrm{La}-\mathrm{ZrO}_{2}(\diamond) 3.5 \% \mathrm{Ni} / \mathrm{K}-\mathrm{ZrO}_{2},(\boldsymbol{\Delta}) 3.5 \% \mathrm{Ni} / \mathrm{K}-\mathrm{La}-\mathrm{ZrO}_{2}$, (曰) Commercial. (reaction conditions: $700^{\circ} \mathrm{C}, \mathrm{S} / \mathrm{C}=5, \mathrm{GHSV}=240000 \mathrm{~h}^{-1}$ ).

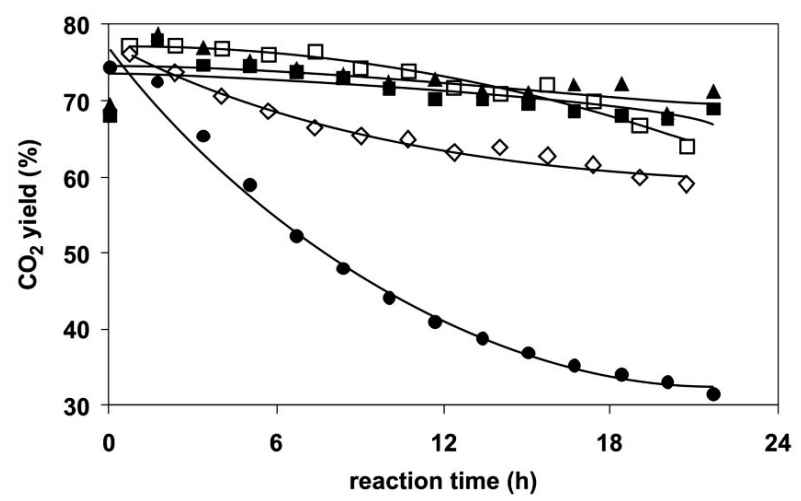

Fig. 4.5. $\mathrm{CO}_{2}$ yield $v s$. time on stream for the stem reforming of $\mathrm{AcOH}$ over $(\bullet) 3.5 \% \mathrm{Ni} / \mathrm{ZrO}_{2},(\square)$ $3.5 \% \mathrm{Ni} / \mathrm{La}-\mathrm{ZrO}_{2} \quad(\diamond) \quad 3.5 \% \mathrm{Ni} / \mathrm{K}-\mathrm{ZrO}_{2}, \quad(\boldsymbol{\Delta}) \quad 3.5 \% \mathrm{Ni} / \mathrm{K}-\mathrm{La}-\mathrm{ZrO}_{2}$, (घ) Commercial. (reaction conditions: $700^{\circ} \mathrm{C}, \mathrm{S} / \mathrm{C}=5, \mathrm{GHSV}=240000 \mathrm{~h}^{-1}$ ). 


\subsubsection{Catalyst characterization after use}

In order to establish the cause of catalyst deactivation, coke deposition as well as metal sintering were investigated. The amount of coke accumulated on the catalysts during $22 \mathrm{~h}$ time on stream (TOS) at $700{ }^{\circ} \mathrm{C}$ was determined with thermogravimetric

Table 4.3. Coke amount after $22 \mathrm{~h}$ time on stream over: $3.5 \% \mathrm{Ni} / \mathrm{ZrO}_{2}, \quad 3.5 \% \mathrm{Ni} / \mathrm{La}-\mathrm{ZrO}_{2}, \quad 3.5 \% \mathrm{Ni} / \mathrm{K}-\mathrm{ZrO}_{2}$ and $3.5 \% \mathrm{Ni} / \mathrm{K}-\mathrm{La}-\mathrm{ZrO}_{2}$.

\begin{tabular}{lc}
\hline Catalyst & Coke amount (\%) \\
\hline $\mathrm{Ni} / \mathrm{ZrO}_{2}$ & 6.5 \\
$\mathrm{Ni} / \mathrm{La}-\mathrm{ZrO}_{2}$ & 1.5 \\
$\mathrm{Ni} / \mathrm{K}-\mathrm{ZrO}_{2}$ & 2.8 \\
$\mathrm{Ni} / \mathrm{K}-\mathrm{La}-\mathrm{ZrO}_{2}$ & 0.7
\end{tabular}
analysis (Table 4.3). Typically, coke burn off occurred around $500^{\circ} \mathrm{C}$ for all the catalysts. The smallest amount of coke deposition was found over $\mathrm{Ni} / \mathrm{K}-\mathrm{La}-\mathrm{ZrO}_{2} \quad$ (0.7 wt.\%). The carbon accumulated in the case of the $\mathrm{Ni} / \mathrm{La}-\mathrm{ZrO}_{2}$ was $1.5 \%$ and in the case of $\mathrm{Ni} / \mathrm{K}-\mathrm{ZrO}_{2}$ catalyst was higher (2.8 wt.\%). Finally,

$\mathrm{Ni} / \mathrm{ZrO}_{2}$ catalyst accumulated the largest amount of deposits $(6.5 \mathrm{wt} . \%)$. These results show that the presence of potassium and lanthanum reduces the amount of accumulated deposits remarkably. TEM and SEM studies of spent catalyst revealed the presence of both filamentous carbon as well as carbon encapsulating nickel particles (not shown).

Comparison of nickel oxide particles size for both fresh and spent catalyst is shown in Table 4.2. Particle size did not increase during use in the case of $\mathrm{Ni} / \mathrm{ZrO}{ }_{2}$ catalysts. A slight decrease was observed in the case of the modified nickel-based catalysts. Therefore, none of the catalysts suffered from metal sintering.

XRD measurements on fresh and used $\mathrm{Ni} / \mathrm{La}-\mathrm{ZrO}_{2}$ confirmed the presence of $\mathrm{La}_{2} \mathrm{O}_{2} \mathrm{CO}_{3}$ based on the existence of a diffraction peak at $2 \Theta=42.3^{\circ}$ (Fig. 4.6) exclusively on the spent $\mathrm{Ni} / \mathrm{La}-\mathrm{ZrO}_{2}$ catalyst. Similar trend was observed for the spent $\mathrm{Ni} / \mathrm{K}-\mathrm{La}-\mathrm{ZrO}_{2}$ (not shown). Typically, XRD measurements on spent catalyst after regeneration (Fig. 4.7c) show the presence of $\mathrm{NiO}$ at $2 \Theta=43.4^{\circ}$, similar to fresh catalyst (Fig. 4.7a), in contrast to spent catalyst without regeneration (Fig. 4.7b). 


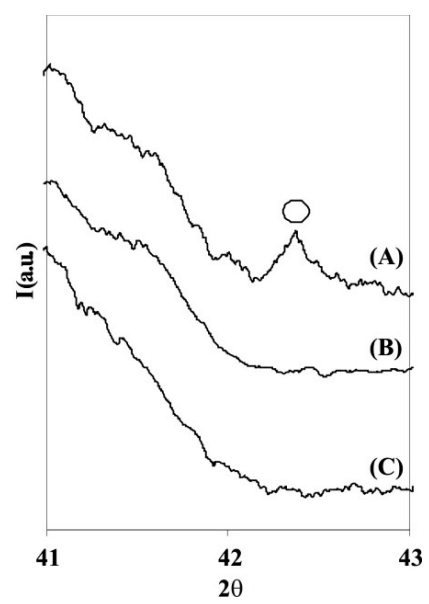

Fig. 4.6. $X R D$ patters of (A) used $\mathrm{Ni} / \mathrm{La}-\mathrm{ZrO}_{2}$; (B) fresh $\mathrm{Ni} / \mathrm{La}-\mathrm{ZrO}_{2}$; (C) Used $\mathrm{Ni} / \mathrm{ZrO}_{2}$ given for comparison; Symbol (०) corresponds to $\mathrm{La}_{2} \mathrm{O}_{2} \mathrm{CO}_{3}$.

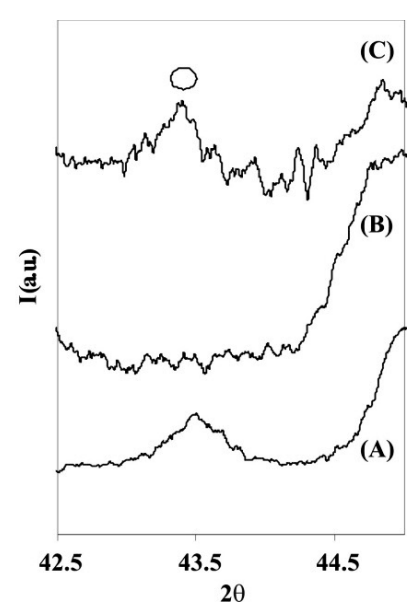

Fig. 4.7. XRD patters of $3.5 \% \mathrm{Ni} / \mathrm{La}-\mathrm{ZrO}_{2}$ (A) before reaction (B) after reaction (C) after regeneration. (०) $\mathrm{NiO}$.

\subsection{Discussion}

One of the major problems with steam reforming reactions is coke deposition which blocks active sites and leads to catalyst deactivation [9, 23]. Metal sintering, on the other hand, may also cause catalyst deactivation, decreasing the number of active sites [12]. In this study, we have used acetic acid as a "model biomass oxygenate" to determine catalyst stability during steam gasification. Our results (Figs. 4.2 and 4.3) show very active catalysts, with complete $\mathrm{AcOH}$ conversion at initial times on stream. Similar trends have been stated in literature. Román Galdámez et al. also reported high $\mathrm{AcOH}$ conversions (85\%) using higher Ni loadings $(8 \% \mathrm{Ni}-\mathrm{Al}-\mathrm{La})$ at $650{ }^{\circ} \mathrm{C}$ but under comparable $\mathrm{S} / \mathrm{C}$ ratio (5.58) and space velocity conditions. However product distribution in their case did differ from our findings. They observed lower amounts of $\mathrm{H}_{2}$ and $\mathrm{CO}_{2}$ and higher amounts of $\mathrm{CO}$ and $\mathrm{CH}_{4}$. On the other hand, Basagiannis et al. [21] showed that when a $17 \% \mathrm{Ni} / \mathrm{La}_{2} \mathrm{O}_{3} / \mathrm{Al}_{2} \mathrm{O}_{3}$ catalyst was used under the same reaction temperature $\left(700{ }^{\circ} \mathrm{C}\right)$ and similar $\mathrm{S} / \mathrm{C}$ ratio $(6)$ and space velocities, $\mathrm{AcOH}$ was only converted $60 \%$. This clearly indicates higher catalyst activities in our case, however, with different profiles of (continuous) deactivation of the non-modified $\mathrm{Ni} / \mathrm{ZrO}_{2}$ catalyst. In addition, the deactivation is also accompanied by changes in the $\mathrm{CO} / \mathrm{CO}_{2}$ ratio, which increases during time on stream. The increase 
in the $\mathrm{CO} / \mathrm{CO}_{2}$ ratio is accompanied by a decrease in $\mathrm{H}_{2}$ production. This suggests an influence on the ability of the catalysts for the WGS reaction.

Observations on metal particle size did not show any metal sintering with or without promoters. Therefore, metal sintering is excluded as a cause of catalyst deactivation in our case. Under similar temperature conditions $\left(550-650{ }^{\circ} \mathrm{C}\right)$, Marquevich et al. [12] observed an increase of nickel particles during steam reforming of sunflower oil over nickel supported on hydrotalcites type materials. The discrepancy between both investigations could be attributed to catalyst type and reaction.

According to our results (Fig. 4.2 and Table 4.3), there is, as suggested above, a direct correlation between coke accumulated on the catalyst and its performance. The more the coke deposited on the catalyst, the more severe the deactivation of the catalyst is; i.e., lower hydrogen yields with time on stream. In previous studies [6] we have showed that on $\mathrm{ZrO}_{2}, \mathrm{AcOH}$ is converted first into acetone which subsequently leads to oligomer/coke formation via condensation/dehydration reactions involving mostly diacetone alcohol, mesytyl oxide and ketene [7]. The complete conversion of $\mathrm{AcOH}$ during the first $10 \mathrm{~h}$ of reaction suggests that part of the catalyst bed is enough to steam reform AcOH. This fact along with coke formation suggests an increase in "C" buildup over the catalyst bed with time on stream. This would decrease the number of active sites for both steam reforming as well as WGS reactions. With regards to WGS reaction, calculations of the ratio $\left(\left[\mathrm{CO}_{2}\right]\left[\mathrm{H}_{2}\right]\right) /[\mathrm{CO}]$ are shown in Fig. 4.8. It can be seen that the WGS reaction is at equilibrium only in the initial stage. The product mixture moves further away from the equilibrium with time on stream, indicating deactivation of the catalyst for WGS during time on stream. This phenomenon is especially pronounced in the case of $\mathrm{Ni} / \mathrm{ZrO}_{2}$. It is known in literature [24-27] that nickel-based catalysts show very poor activity (TOF) for WGS reaction but are very active for steam reforming. Further, the deactivation curves in Figs. 4.2 and 4.3 indicate that only part of the $\mathrm{Ni} / \mathrm{ZrO}_{2}$ catalyst bed is sufficient to keep the near complete steam reforming conversion, as discussed above. The result in Fig. 4.8 reveals that the catalyst deactivates much faster for WGS.

Promotion of the $\mathrm{Ni} / \mathrm{ZrO}_{2}$ catalyst shows promise, as evidenced in this study. All 
modified catalysts exhibit less severe deactivation. The combination of both promoters results in the most stable catalyst for WGS (Fig. 4.8).

It has been reported [28] that addition of potassium to $\mathrm{Al}_{2} \mathrm{O}_{3} \quad$ supported catalysts enhances coke gasification during biomass steam reforming. No catalyst deactivation was

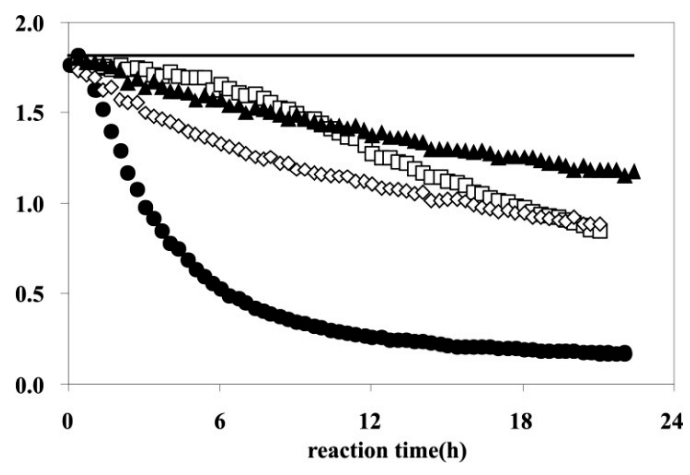

Fig. 4.8. $\left[\mathrm{CO}_{2}\right]\left[\mathrm{H}_{2}\right] /[\mathrm{CO}]$ ratio vs. time on stream for the stem reforming of $\mathrm{AcOH}$ over (•) $3.5 \% \mathrm{Ni} / \mathrm{ZrO}_{2},(\square)$ $3.5 \% \mathrm{Ni} / \mathrm{La}-\mathrm{ZrO}_{2}(\diamond) 3.5 \% \mathrm{Ni} / \mathrm{K}-\mathrm{ZrO}_{2}$, ( $\mathrm{ZrO}_{2}$ (reaction conditions: $700^{\circ} \mathrm{C}, \mathrm{S} / \mathrm{C}=5$, GHSV $=240000$ $\left.\mathrm{h}^{-1}\right)$.

\section{observed for potassium modified}

catalyst used for wood gasification, even after $30 \mathrm{~h}$ time on stream. Little or no carbon was found on the used catalyst. Those results are in line with our observation. It has been proposed in literature [10] that the presence of alkali induces a strong electric field in its vicinity, enhancing water dissociation and facilitating formation of reactive hydroxyl groups. The increase in water activation for potassium doped catalysts as compared to the case in which the alkali is not present might result in enhanced steam reforming/preventing of the carbon deposits, thus reducing coke deposition. Indeed higher ethanol steam reforming activity was observed when potassium was added in $\mathrm{Ni} / \mathrm{MgO}$ [29]. However, the enhanced steam reforming activity could not be observed in our experiments as the products yields were close to thermodynamic equilibrium at initial time on stream.

In addition, it is important to point out the strong influence of potassium on the reduction temperature of nickel oxide, making it more difficult. In literature, there is a debate about the role of alkalis in the reduction of nickel oxide. Some authors [29, 30] have shown that potassium promotes the reduction of nickel oxide, supported on $\mathrm{MgO}$. Contrary to this and in line with our observations, it has been reported that addition of potassium retards the reduction process by impeding the dissociation of $\mathrm{H}_{2}$ or by blocking of the pores by potassium compounds, limiting $\mathrm{H}_{2}$ accessibility or preventing $\mathrm{H}_{2} \mathrm{O}$ to leave the reduced metal site [31, 32]. 
Catalyst stability was further improved by adding lanthanum. The amount of carbon deposits determined by TGA (1.5 wt.\%) clearly indicates that presence of lanthanum lowers carbon accumulation. Basagiannis et al. [21] observed similar trends, quantifying only $0.43 \%$ carbon over $\mathrm{Ni} / \mathrm{La}_{2} \mathrm{O}_{3} / \mathrm{Al}_{2} \mathrm{O}_{3}$ after steam reforming of $\mathrm{AcOH}$ for $2 \mathrm{~h}$ at $700{ }^{\circ} \mathrm{C}$. The positive influence of lanthanum has been reported in literature [17, 18, 26]. Olsbye et al. [33] reported that, under dry reforming of $\mathrm{CH}_{4}$ conditions, the addition of $1.7 \mathrm{wt} . \%$ lanthanum to $0.15 \mathrm{wt} . \% \mathrm{Ni} / \mathrm{Al}_{2} \mathrm{O}_{3}$ decreases coke formation by almost $50 \%$. They could partially explain these results based on the different nickel cluster size of the promoted and un-promoted catalysts: the larger the nickel clusters the more the carbon deposition. They also speculated that the presence of lanthanum leads to the formation of mixed phases with cationic vacancies which enhance mobility of lattice oxygen anions. In this way, surface reaction between carbon-containing species and reactive oxygen species is favored.

According to Zhang et al. [17] and Guo et al. [18], formation of coke during dry reforming of $\mathrm{CH}_{4}$ over $\mathrm{Ni} / \mathrm{La}_{2} \mathrm{O}_{3}$ catalysts, is hindered by the presence of lanthanum as $\mathrm{La}_{2} \mathrm{O}_{2} \mathrm{CO}_{3}$. This oxy-carbonate phase, which should be the result of the reaction between $\mathrm{La}_{2} \mathrm{O}_{3}$ and $\mathrm{CO}_{2}$ (product of gasification) is suggested to limit the formation of encapsulating carbon layer around the nickel particles and, thus, minimizing deactivation $[16,17]$. It is further suggested that due to the synergetic sites which consist of nickel and lanthanum, the carbon species formed on the nickel sites would be favorably removed by the oxygen species originating from $\mathrm{La}_{2} \mathrm{O}_{2} \mathrm{CO}_{3}$. Indeed, a close look at the XRD patterns (see Fig. 4.6) shows the presence of the oxy-carbonate phase of lanthanum in the catalyst after use. As expected, this phase was absent in a $\mathrm{Ni} / \mathrm{ZrO}_{2}$ and a fresh $\mathrm{Ni}-\mathrm{La} / \mathrm{ZrO}_{2}$ catalyst. The low intensity of the peak could be due to the low lanthanum, content in our catalysts $(5 \%)$ compared to the $\mathrm{Ni} / \mathrm{La}_{2} \mathrm{O}_{3}$ used in the previous investigations $[16,17]$.

It was also observed in the XRD patterns of all spent catalysts (not shown here) that no peaks related to nickel containing phases were observed. However, the main peak of nickel oxide appeared again after exposing the catalysts to air for few minutes (see Fig. 4.7). One could think of four different explanations: (i) formation of nickel zirconia stoichiometric phases, (ii) formation of highly dispersed nickel particles, (iii) formation of a nickel amorphous phase and (iv) formation of $\mathrm{Ni}_{3} \mathrm{C}$. 
The formation of nickel zirconia stoichiometric phases such as $\mathrm{Ni}_{3} \mathrm{ZrO}$ or $\mathrm{Ni}_{4} \mathrm{Zr}_{2} \mathrm{O}$ implies dissolving of $\mathrm{NiO}$ in the $\mathrm{ZrO}_{2}$ lattice. It has been reported that the solubility of nickel particles in yttrium stabilized zirconia (YSZ) is much smaller when the nickel oxide is reduced to metallic nickel [34]. The presence of a nickel oxide peak and the absence of $\mathrm{Ni}_{3} \mathrm{ZrO}(2 \theta=37.729$ [35] $)$ and $\mathrm{Ni}_{4} \mathrm{Zr}_{2} \mathrm{O}(2 \theta=38.314$ [36]) at the diffraction pattern of the calcined catalysts at $725^{\circ} \mathrm{C}$ for $15 \mathrm{~h}$., suggest that stoichiometric nickel-zirconia phases are not formed during reaction, at $700{ }^{\circ} \mathrm{C}$ for $20 \mathrm{~h}$.

An alternative explanation could be the presence of nickel in an amorphous phase, as suggested by Nam et al. [37]. They studied methane dry reforming over nickel-based perovskite catalysts. In a similar way, no nickel or nickel oxide peaks were observed in the XRD patters after reaction. The absence of nickel and nickel oxide peaks was attributed to either amorphous nickel oxide or highly dispersed nickel particles. It was concluded that the presence of highly dispersed nickel ions in the fresh catalyst in combination with a reducing atmosphere during reaction could result in very small nickel particles even after reaction. However, highly dispersed nickel particles are not expected to be present under our reaction conditions, taking into account the nickel oxide particles sizes of the fresh catalysts $(\sim 20 \mathrm{~nm})$.

The formation of $\mathrm{Ni}_{3} \mathrm{C}$ is also proposed as a possible explanation for the absence of nickel species in the XRD patterns of the used catalysts. Bai et al. [38] observed the formation of $\mathrm{Ni}_{3} \mathrm{C}$ crystallites at high temperatures as a result of the interaction between nickel metal and the deposited carbon. Although De Deken et al. [39] reported that $\mathrm{Ni}_{3} \mathrm{C}$ is thermodynamically metastable above $400{ }^{\circ} \mathrm{C}$, they claimed a transformation from the graphitic to the carbidic form during the cooling of the catalyst. The presence of $\mathrm{Ni}_{3} \mathrm{C}$ cannot be ruled out but it cannot be observed in our experimental results due to overlapping of $\mathrm{Ni}_{3} \mathrm{C}$ and $\mathrm{ZrO}_{2}$ peaks. The actual reason for not observing a nickel phase as detected with XRD remains unclear.

To summarize, $\mathrm{Ni} / \mathrm{ZrO}_{2}$ catalysts modified with lanthanum and potassium are reasonably stable for the steam reforming of acetic acid by minimizing coke formation and/or deposition. They show promise for the steam reforming of more complex biomass derived oxygenates, which are currently under study. 


\subsection{Conclusions}

It has been shown that $\mathrm{Ni} / \mathrm{ZrO}_{2}$ is an active catalyst for the steam reforming of biomass related oxygenates. However, it loses activity with time on stream, as a result of deactivation for both the steam reforming and WGS reactions. WGS seems to be more susceptible to deactivation than steam reforming. Carbon deposition is suggested to be the cause of the deactivation. Addition of potassium and/or lanthanum improves the catalyst life, resulting, in the case of lanthanum-based catalysts, in a better performance than the commercial pre-reforming catalyst. Addition of potassium is suggested to enhance gasification of carbonaceous species by facilitating the formation of reactive hydroxyl groups. Lanthanum is proposed to enhance coke combustion by forming oxygen containing species during reaction $\left(\mathrm{La}_{2} \mathrm{O}_{2} \mathrm{CO}_{3}\right)$. 


\section{References}

[1] K.-A. Adamson, Energy Policy 32 (2004) 1231-1242.

[2] F. Bimbela, M. Oliva, J. Ruiz, L. Garcia, and J. Arauzo, Journal of Analytical and Applied Pyrolysis 79 (2007) 112-120.

[3] G. van Rossum, S.R.A. Kersten, and W.P.M. van Swaaij, Industrial \& Engineering Chemistry Research 46 (2007) 3959-3967.

[4] C. Rioche, S. Kulkarni, F.C. Meunier, J.P. Breen, and R. Burch, Applied Catalysis B: Environmental 61 (2005) 130-139.

[5] D. Sutton, B. Kelleher, and J.R.H. Ross, Fuel Processing Technology 73 (2001) 155-173.

[6] K. Takanabe, K.-i. Aika, K. Seshan, and L. Lefferts, Chemical Engineering Journal 120 (2006) 133-137.

[7] K. Takanabe, K. Aika, K. Seshan, and L. Lefferts, Journal of Catalysis 227 (2004) 101-108.

[8] K. Takanabe, K.-i. Aika, K. Inazu, T. Baba, K. Seshan, and L. Lefferts, Journal of Catalysis 243 (2006) 263-269.

[9] J.R. Rostrup-Nielsen, Catalysis: Science and Technology 5 (1984) 1-117.

[10] M.A. Henderson, Surface Science Reports 46 (2002) 1-308.

[11] J. H. Larsen, and I. Chorkendorff, Surface Science Reports 35 (1999) 163-222.

[12] M. Marquevich, X. Farriol, F. Medina, and D. Montané, Catalysis Letters 85 (2003) 41-48.

[13] P.N. Kechagiopoulos, S.S. Voutetakis, A.A. Lemonidou, and I.A. Vasalos, Energy Fuels 20 (2006) 2155-2163.

[14] J.W. Snoeck, G.F. Froment, and M. Fowles, Industrial Engineering Chemistry Research 41 (2002) 3548-3556.

[15] N.V. Parizotto, R.F. Fernandez, C.M.P. Marques, and J.M.C. Bueno, Studies in Surface Science and Catalysis 167 (2007) 421-426.

[16] S.G. Chen, and R.T. Yang, Energy Fuels 11 (1997) 421-427.

[17] Z. Zhang, and X.E. Verykios, Applied Catalysis A: General 138 (1996) 109-133.

[18] J. Guo, H. Lou, Y. Zhu, and X. Zheng, Materials Letters 57 (2003) 4450-4455.

[19] H. Schaper, E.B.M. Doesburg, and L.L. Van Reijen, Applied Catalysis 7 (1983) 211-220.

[20] N.S. Figoli, P.C. Largentiere, A. Arcoya, and X.L. Seoane, Journal of Catalysis 155 (1995) 95-105. 
[21] A.C. Basagiannis, and X.E. Verykios, Applied Catalysis A: General 308 (2006) 182-193.

[22] J.R. Galdamez, L. Garcia, and R. Bilbao, Energy Fuels 19 (2005) 1133-1142.

[23] D.L. Trimm, Catalysis Today 49 (1999) 3-10.

[24] K.G. Azzam, I.V. Babich, K. Seshan, and L. Lefferts, Journal of Catalysis 251 (2007) 153-162.

[25] J. Comas, F. Mariño, M. Laborde, and N. Amadeo, Chemical Engineering Journal 98 (2004) 61-68.

[26] F. Auprêtre, C. Descorme, and D. Duprez, Catalysis Communications 3 (2002) 263-267.

[27] K. Norman, Sandia report (2007) 37.

[28] L.K. Mudge, E.G. Baker, D.H. Mitchell, and M.D. Brown, Journal of Solar Energy Engineering, Transactions of the ASME 107 (1985) 88-92.

[29] F. Frusteri, S. Freni, V. Chiodo, L. Spadaro, O. Di Blasi, G. Bonura, and S. Cavallaro, Applied Catalysis A: General 270 (2004) 1-7.

[30] F. Arena, F. Frusteri, and A. Parmaliana, Applied Catalysis A: General 187 (1999) 127-140.

[31] F.R. van den Berg, M.W.J. Craje, A.M. van der Kraan, and J.W. Geus, Applied Catalysis A: General 242 (2003) 403-416.

[32] C.-K. Kuei, J.-F. Lee, and M.-D. Lee, Chemical Engineering Communications 101 (1991) $77-92$.

[33] U. Olsbye, O. Moen, A. Slagtern, and I.M. Dahl, Applied Catalysis A: General 228 (2002) 289-303.

[34] D. Linderoth, Journal of the American Ceramic Society 84 (2001) 2652-2656.

[35] R. Mackay, and H.F. Franzen, Journal of Alloys and Compounds 186 (1992) L7-L10.

[36] R. Mackay, G.J. Miller, and H.F. Franzen, Journal of Alloys and Compounds 204 (1994) 109-118.

[37] H.C. Nam, S.H. Lee, H. Jung, K.Y. Lee, Studies in Surface Science and Catalysis 119 (1998) 843-848.

[38] Z. Bai, H. Chen, B. Li, and W. Li. 2007, International Journal of Hydrogen Energy 32 (2007) 32-37.

[39] J. De Deken, P.G. Menon, G.F. Froment, and G. Haemers, Journal of Catalysis 70 (1981) 225-229. 



\section{Chapter 5}

\section{Steam reforming of phenol over Ni-based catalysts - A comparative study}

The influence of the support in the steam reforming of phenol at $700{ }^{\circ} \mathrm{C}$ has been examined over $\mathrm{Ni} / \mathrm{K}-\mathrm{La}-\mathrm{ZrO} \mathrm{O}_{2}$ and $\mathrm{Ni} / \mathrm{Ce}-\mathrm{ZrO} \mathrm{O}_{2}$. Both catalysts exhibit high activity and good stability in terms of phenol conversion. However, $\mathrm{Ni} / \mathrm{K}-\mathrm{La}-\mathrm{ZrO}_{2}$ showed a pronounced change in product distribution with TOS, which is related to deactivation for the water-gas shift. The high activity observed for the water-gas shift over the unsupported nickel and the difference in the location of coke between the two nickel catalysts are suggested to be the key reasons for the difference in catalyst stability. The red-ox properties of $\mathrm{Ce}-\mathrm{ZrO}_{2}$ are proposed to result in more oxygenated species ( $\mathrm{O}$ - and $\mathrm{OH}-$ ) than the non-red-ox $\mathrm{K}-\mathrm{La}-\mathrm{ZrO} \mathrm{O}_{2}$. These oxygenated species, which are suggested to undergo back-spillover from the support to the nickel surface, could be responsible for keeping the nickel surface clean by gasifying the carbonaceous species accumulated on nickel. 



\subsection{Introduction}

Due to concerns about fossil fuels depletion and their undesirable environmental effects, sustainable and renewable sources have recently gained tremendous interest. Hydrogen, if produced from renewables such as biomass, with no net contribution to $\mathrm{CO}_{2}$ emissions, is recognized as one of the most promising clean fuels and energy carriers for the green future scenario [1-3]. Biomass gasification has recently drawn attention as a renewable hydrogen technology [4]. One of the most critical problems in biomass gasification is the formation of tars [5-7]. These compounds are largely aromatic hydrocarbons, such as phenol and naphthalene, considered to be the condensable fraction of the organic gasification products. Tars cause serious hazard to the equipment downstream due to their condensation at low temperatures, resulting in a reduction in performance and in increasing maintenance requirements. Therefore, removal of tars is highly desirable. Catalytic tar reforming is one attractive approach for tar elimination during biomass gasification since a high value gas product, syngas, is produced $[5,8,9]$.

Nickel-based catalysts are the most widely reported catalysts in literature for steam reforming [10]. However, they undergo severe coking, resulting in catalyst deactivation. Extensive research on the modification of conventional nickel catalysts, such as $\mathrm{Ni} / \mathrm{Al}_{2} \mathrm{O}_{3}$, has been reported to improve catalyst stability. Most of the efforts have been focused on the steam reforming of model compounds, such as methane in the case of natural gas or acetic acid in the case of pyrolysis oil [11-13]. In the context of tar reforming, benzene and naphthalene (main constituents of tar [14]), have been particularly the most studied model compoonents [5, 9, 15]. Sato et al. [5] studied the steam reforming of naphthalene over a tungsten-promoted nickel catalyst at $825{ }^{\circ} \mathrm{C}$ and with a steam to carbon ratio $(\mathrm{S} / \mathrm{C})$ of 1.8 . This catalyst exhibited higher activity and better resistance to coking than commercial available nickel-based catalysts. Under comparable reaction conditions $\left(800{ }^{\circ} \mathrm{C}, \mathrm{S} / \mathrm{C}=1\right)$, Furusawa et al. [15] tested a $\mathrm{Ni} / \mathrm{MgO}$ catalyst which also showed good stability for the steam reforming of a mixture of naphthalene and benzene during $10 \mathrm{~h}$ time on stream. It has been reported [16] that addition of basic metal oxides such as $\mathrm{MgO}$ increases the rate of coke gasification as a result of the enhanced water adsorption, thus improving catalyst lifetime. 
Despite the numerous research works on naphthalene steam reforming, only a limited number of publications are available in literature concerning phenol as main constituent of tar. Polychronopoulou et al. [7] studied the steam reforming of phenol over MgO-based supported $\mathrm{Rh}$ metal catalysts at $700{ }^{\circ} \mathrm{C}$ and $\mathrm{S} / \mathrm{C}$ of 13.3. Although nobel metal and MgO-based catalysts can suppress coking, the authors reported an initial partial deactivation of the catalysts which was attributed to carbon accumulation on the catalyst surface.

Our previous study [13] on the steam reforming of biomass related oxygenates, particularly acetic acid, was devoted to design a stable nickel-zirconia-based catalyst which showed high resistance to coking when promoting the catalyst with potassium and lanthanum. We suggested that potassium enhances gasification of carbonaceous species by facilitating the formation of reactive hydroxyl groups whereas lanthanum enhances coke combustion by forming oxygen containing species during reaction $\left(\mathrm{La}_{2} \mathrm{O}_{2} \mathrm{CO}_{3}\right)$. Additionally, we recently developed a platinum-ceria-based catalyst which also showed excellent stability for the steam reforming of acetic acid in the presence of small amounts of oxygen [17]. The red-ox characteristics of $\mathrm{CeO}_{2}$ are key reasons to justify the excellent catalytic stability, as both oxygen and water can be used as oxidants.

The main objective of the present work is to investigate the steam reforming of phenol over the potassium and lanthanum promoted nickel catalyst designed for the steam reforming of acetic acid and to compare its catalytic performance with that of a new developed nickel-ceria-based catalyst. Development of a stable catalyst for the steam reforming of both light and heavy oxygenates is essential to have a promising candidate for the steam reforming of the entire fraction of pyrolysis oil.

\subsection{Experimental}

\subsubsection{Catalyst preparation}

Catalysts were prepared by wet impregnation technique. Yttrium stabilized zirconia (TOSOH, TZ-8Y) was first calcined at $850{ }^{\circ} \mathrm{C}$ (heating rate $5{ }^{\circ} \mathrm{C} \cdot \mathrm{min}^{-1}$ ) in flowing air $\left(30 \mathrm{ml} \cdot \mathrm{min}^{-1}\right)$ for $15 \mathrm{~h}$. For the cerium-based support, the powder was then impregnated with an aqueous solution of $\mathrm{Ce}\left(\mathrm{NO}_{3}\right)_{3} \cdot 6 \mathrm{H}_{2} \mathrm{O}$ (Fuka) to yield a catalyst 
support with $8.2 \%$ ceria loading, here denoted as $\mathrm{Ce}-\mathrm{ZrO}_{2}$. The potassium-lanthanum-based promoted support, here denoted as $\mathrm{K}-\mathrm{La}-\mathrm{ZrO}_{2}$, was prepared by adding aqueous solutions of $\mathrm{KNO}_{3}$ and $\mathrm{La}\left(\mathrm{NO}_{3}\right)_{3} \cdot 6 \mathrm{H}_{2} \mathrm{O}$ to the zirconia powder to yield to $1 \mathrm{wt} . \% \mathrm{~K}$ and $5 \mathrm{wt} . \% \mathrm{La}$. Each catalytic support solution was mixed for $2 \mathrm{~h}$ and then dried at $50^{\circ} \mathrm{C}$ in vacuum for $4 \mathrm{~h}$ in a rotary evaporator. After impregnation, both catalyst supports were first calcined at $600{ }^{\circ} \mathrm{C}$ (heating rate $5^{\circ} \mathrm{C} \cdot \mathrm{min}^{-1}$ ) for $6 \mathrm{~h}$ and then impregnated with $0.1 \mathrm{M} \mathrm{Ni}\left(\mathrm{NO}_{3}\right)_{2} \cdot 6 \mathrm{H}_{2} \mathrm{O}$ (Alfa Aesar) solution to load the promoted-zirconia supports with $3.5 \mathrm{wt} \%$ Ni. Each catalytic solution was mixed again for $2 \mathrm{~h}$ and then dried at $50{ }^{\circ} \mathrm{C}$ in vacuum for $4 \mathrm{~h}$ in a rotary evaporator. Finally the catalysts were calcined at $725{ }^{\circ} \mathrm{C}$ (heating rate $5{ }^{\circ} \mathrm{C} \cdot \mathrm{min}^{-1}$ ) in flowing air $\left(30 \mathrm{ml} \cdot \mathrm{min}^{-1}\right)$ for $15 \mathrm{~h}$ and then crushed and sieved to give grains of 0.3-0.6 mm. Hereafter, these catalysts will be referred as $\mathrm{Ni} / \mathrm{Ce}-\mathrm{ZrO}_{2}$ and $\mathrm{Ni} / \mathrm{K}-\mathrm{La}-\mathrm{ZrO}_{2}$.

$\mathrm{NiO}$ was prepared by calcining $\mathrm{Ni}\left(\mathrm{NO}_{3}\right)_{2}$ at $600{ }^{\circ} \mathrm{C}$ in flowing air $\left(30 \mathrm{ml} \cdot \mathrm{min}^{-1}\right)$ for $6 \mathrm{~h}$. The resulting powder was crushed and sieved to give grains of $0.3-0.6 \mathrm{~mm}$.

\subsubsection{Catalyst characterization}

The elemental composition of the catalysts was determined with X-ray fluorescence spectroscopy (XRF) (Phillips PW 1480 spectrometer). Specific surface area measurements were carried out with $\mathrm{N}_{2}$ adsorption-desorption at $77 \mathrm{~K}$ by the BET method (Micromeritics TriStar).

XRD patterns were recorded with a Philips X'Pert APD using $\mathrm{Cu} \mathrm{K} \alpha$ radiation. Spectra were registered with $2 \theta$ between 5 and $80^{\circ}$. Nickel crystallite diameter was estimated by X-Ray line broadening analysis (XLBA) using the Scherrer equation.

X-Ray photoelectron spectra (XPS) were recorded on a Physical Electronics Quantera XPS system using a monochromatic Al Ka (1486.6 eV) X-ray source operated at $25 \mathrm{~W}$ (beam diameter $100 \mu \mathrm{m}$ with charge neutralization).

Temperature program oxidation (TPO) experiments were performed to quantify the amount of coke deposits on the used catalysts. Prior to oxidation, samples were pretreated in $\mathrm{Ar}$ at $500{ }^{\circ} \mathrm{C}$ for $20 \mathrm{~min}$. Subsequently, samples were first cooled down to room temperature in $\mathrm{Ar}$ and then heated to $800{ }^{\circ} \mathrm{C}$ in $1 \% \mathrm{O}_{2} / \mathrm{Ar}$ at $5{ }^{\circ} \mathrm{C} \cdot \mathrm{min}^{-1}$. 
Carbonaceous deposits were oxidized to $\mathrm{CO}_{\mathrm{x}}$, which passed through a methanator and finally detected with a flame ionization detector. This enabled to differentiate between oxygen consumption during TPO for coke removal and re-oxidation of ceria.

\subsubsection{Catalytic testing}

For steam reforming of phenol and water-gas shift catalytic experiments, $15 \mathrm{mg}$ of catalyst diluted with quartz particles with grains of 0.3-0.6 mm (ratio 1:5.5) was loaded in an alumina fixed-bed reactor ( $4 \mathrm{~mm}$ i.d.) and held in place by quartz wool plugs. The catalyst was first reduced at $650{ }^{\circ} \mathrm{C}$ in-situ in $5 \% \mathrm{H}_{2} / \mathrm{N}_{2}$ flow $\left(50 \mathrm{ml} \cdot \mathrm{min}^{-1}\right)$ for $1 \mathrm{~h}$. After purging with $\mathrm{N}_{2}$ for $15 \mathrm{~min}$, the temperature was increased to $700{ }^{\circ} \mathrm{C}$. For the steam reforming of phenol, an aqueous solution of phenol with a steam to carbon molar ratio $(\mathrm{S} / \mathrm{C})$ of 20 was delivered by means of a pulse-free syringe pump (Isco Model $500 \mathrm{D}$ ). This solution was evaporated at $210{ }^{\circ} \mathrm{C}$ in a gasifier before entering the reactor. Nitrogen was used both as an inert carrier gas and as an internal standard. The feed delivery system was heated at $185{ }^{\circ} \mathrm{C}$ to avoid condensation. The gas feed, consisting of $0.23 \% \mathrm{CH}_{3} \mathrm{COOH} / 27.5 \% \mathrm{H}_{2} \mathrm{O} /$ balance $\mathrm{N}_{2}$, was introduced to the fixed-bed reactor. For the water-gas shift experiments, water was added through a saturator at room temperature which led to a stable water concentration of $0.98 \%$. The rest of the gas feed consisted of $1.8 \% \mathrm{CO}, 53 \% \mathrm{~N}_{2}$ and $44.2 \%$ He. For blank experiments, $100 \mathrm{mg}$ of quartz particles was loaded in the fixed-bed reactor and held by quartz wool plugs.

The composition of the product mixture was determined with an on-line gas chromatograph (GC, Varian CP-3800) equipped with Hayesep Q, Hayesep T, Molsieve 13X, Molsieve 5A and CP-Wax 52CB columns for separation. For the quantification of permanent gases, two thermal conductivity detectors (TCD) were used, while for quantification of the hydrocarbons a flame ionization detector (FID) was applied.

Phenol conversion was calculated as the number of moles of phenol reacted divided by the number of moles of phenol fed.

The hydrogen yield was defined as the percentage of the maximum amount of hydrogen that can be produced, based on Eq. 5.1. 


$$
\mathrm{C}_{6} \mathrm{H}_{5} \mathrm{OH}+11 \mathrm{H}_{2} \mathrm{O} \rightarrow 6 \mathrm{CO}_{2}+14 \mathrm{H}_{2}
$$

For carbon-containing compounds, the yields were calculated based on $\mathrm{C}_{1}$ equivalent values.

\subsection{Results}

\subsubsection{Catalyst characterization}

Table 5.1 compiles the physico-chemical characteristics of the catalysts. Nickel, lanthanum and cerium were in the range intended for preparation. However, only $1 / 3$ of the expected potassium remained in the catalyst. Following each step in the catalyst preparation by XRF (data not shown) it was found that $\sim 20 \%$ of the potassium was lost during preparation and the other $40 \%$ was lost during calcination, possibly as volatile species. The BET surface area and nickel crystallite diameter of the nickel supported catalysts were comparable. As expected, the BET surface area of the unsupported nickel was $\sim 6$ times lower than the supported catalysts and nickel crystallites diameter $\sim 3$ times larger.

Table 5.1. Catalysts elemental analysis and BET surface area of fresh samples.

\begin{tabular}{lcccccc}
\hline \multirow{2}{*}{ Catalyst } & \multicolumn{3}{c}{ Content (wt.\%) } & $\begin{array}{c}\text { Surface area } \\
\left(\mathrm{m}^{2} \cdot \mathrm{g}^{-1}\right)\end{array}$ & $\begin{array}{c}\text { Crystallite diameter } \\
(\mathrm{nm})\end{array}$ \\
\cline { 2 - 6 } & $\mathrm{Ni}$ & $\mathrm{La}$ & $\mathrm{K}$ & $\mathrm{Ce}$ & 14.6 & 17 \\
\hline $\mathrm{Ni} / \mathrm{Ce}-Y S Z$ & 3.21 & - & - & 6.36 & 11.1 & 16 \\
$\mathrm{Ni} / \mathrm{K}-\mathrm{La}-\mathrm{YSZ}$ & 3.41 & 4.77 & 0.34 & - & 1.9 & 45 \\
Unsupported Ni & - & - & - & - & & \\
\hline
\end{tabular}

Table 5.2 shows the surface composition of unsupported nickel oxide, as determined by XPS. Magnesium, carbon, nitrogen and calcium were the only impurities observed. Magnesium and carbon were present in small amounts $(\sim 5 \%)$ whereas nitrogen and calcium were present in insignificant amounts $(<0.5 \%)$.

Table 5.2. XPS analysis of a fresh $\mathrm{NiO}$ sample.

\begin{tabular}{ccccccc}
\cline { 2 - 7 } & $\mathrm{C}$ & $\mathrm{N}$ & $\mathrm{O}$ & $\mathrm{Mg}$ & $\mathrm{Ca}$ & $\mathrm{Ni}$ \\
\hline Average (\%) & 5.71 & 0.44 & 43.98 & 4.78 & 0.08 & 45.00 \\
\hline
\end{tabular}




\subsubsection{Catalyst testing}

\subsubsection{Steam reforming of phenol over $\mathrm{K}-\mathrm{La}-\mathrm{ZrO} \mathrm{O}_{2}$ and $\mathrm{Ni} / \mathrm{K}-\mathrm{La}-\mathrm{ZrO} \mathrm{O}_{2}$}

Fig. 5.1 shows the phenol conversion and product yields over $\mathrm{K}-\mathrm{La}-\mathrm{ZrO}_{2}$ at $700{ }^{\circ} \mathrm{C}$. At initial time on stream (TOS) 15\% of phenol was converted to mainly CO and smaller amounts of $\mathrm{CO}_{2}$ and $\mathrm{H}_{2}$. No $\mathrm{CH}_{4}$ was observed throughout the experiment, indicating that only steam reforming products were formed. Rapid deactivation of the catalyst support was apparent during this period as evidenced by the decrease in phenol conversion and gas yields. After $\sim 1.5 \mathrm{~h}$ TOS the system reached steady state, with phenol conversion of $\sim 5 \%$.

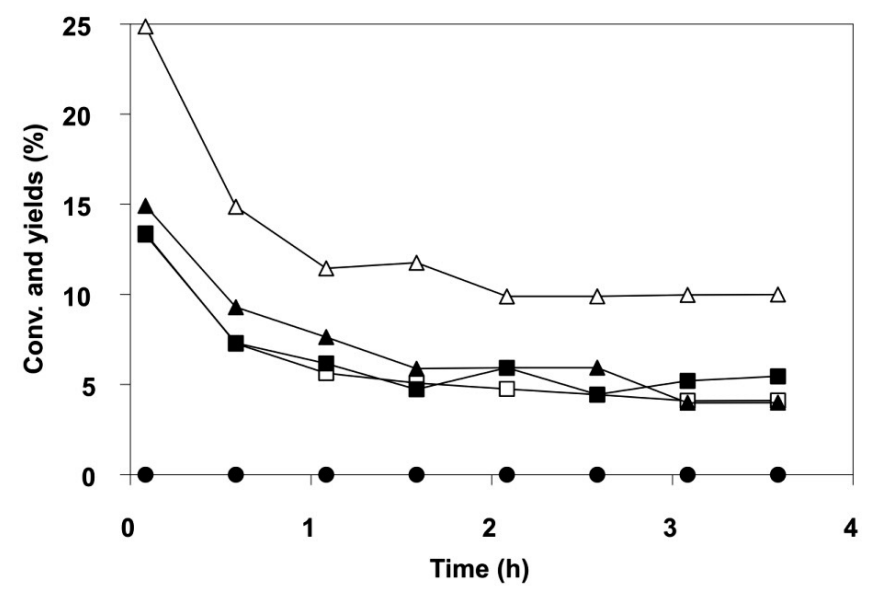

Fig. 5.1. Conversion and yields $v s$. time on stream for the steam reforming of phenol over $\mathrm{K}-\mathrm{La}-\mathrm{ZrO}_{2}$. Reaction conditions: $700{ }^{\circ} \mathrm{C}, \mathrm{S} / \mathrm{C}=20, \mathrm{GHSV}=950000 \mathrm{~h}^{-1}$. (घ) phenol, (ם) $\mathrm{H}_{2},(\boldsymbol{\Delta}) \mathrm{CO}_{2},(\Delta) \mathrm{CO},(\bullet)$ $\mathrm{CH}_{4}$.

The catalytic performance of $\mathrm{Ni} / \mathrm{K}-\mathrm{La}-\mathrm{ZrO}_{2}$ is shown in Fig. 5.2. Addition of nickel to the $\mathrm{K}-\mathrm{La}-\mathrm{ZrO}_{2}$ support increased phenol conversion remarkably, up to $\sim 85 \%$. In contrast to the results obtained in the absence of nickel, $\mathrm{H}_{2}$ and $\mathrm{CO}_{2}$ were the main gas products, whereas $\mathrm{CO}$ was present in small amounts. No $\mathrm{CH}_{4}$ was observed throughout the whole experiment. $\mathrm{Ni} / \mathrm{K}-\mathrm{La}-\mathrm{ZrO}_{2}$ was fairly stable in terms of phenol conversion during $22 \mathrm{~h}$ TOS. Interestingly, however, product distribution changed in time. $\mathrm{H}_{2}$ and $\mathrm{CO}_{2}$ yields decreased from $90 \%$ to $78 \%$ and from $86 \%$ to $65 \%$, respectively. On the contrary, CO yield increased from $20 \%$ to $32 \%$. 


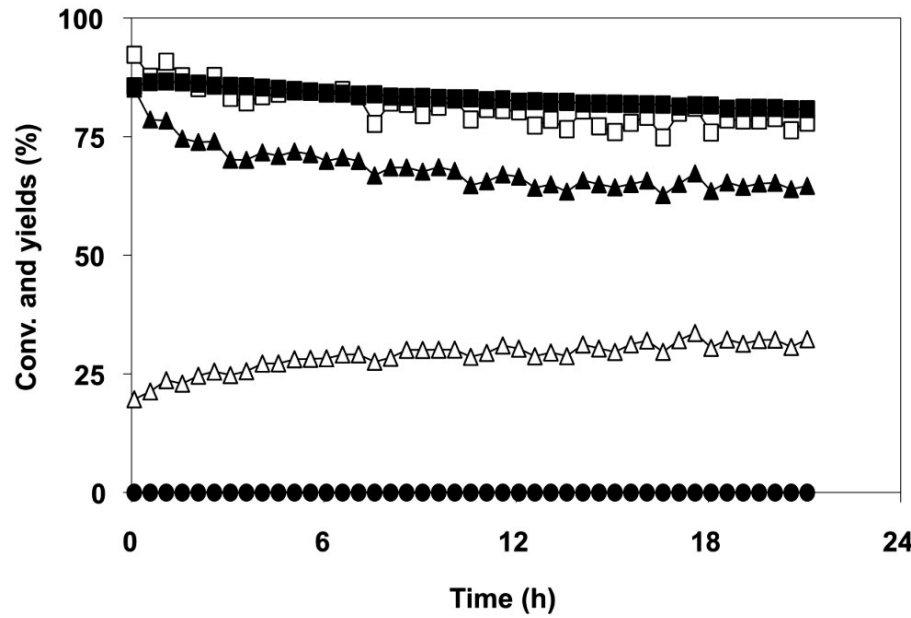

Fig. 5.2. Conversion and yields $v s$. time on stream for the steam reforming of phenol over $\mathrm{Ni} / \mathrm{K}-\mathrm{La}-\mathrm{ZrO}_{2}$. Reaction conditions: $700{ }^{\circ} \mathrm{C}, \mathrm{S} / \mathrm{C}=20, \mathrm{GHSV}=950000 \mathrm{~h}^{-1}$. (घ) phenol, ( $\left.\square\right) \mathrm{H}_{2},(\boldsymbol{\Delta})$ $\mathrm{CO}_{2},(\Delta) \mathrm{CO},(\bullet) \mathrm{CH}_{4}$.

\subsubsection{Steam reforming of phenol over $\mathrm{Ce}-\mathrm{ZrO} \mathrm{O}_{2}$ and $\mathrm{Ni} / \mathrm{Ce}-\mathrm{ZrO} \mathrm{O}_{2}$}

Fig. 5.3 represents a typical experimental result of steam reforming of phenol over $\mathrm{Ce}-\mathrm{ZrO}_{2}$ at $700{ }^{\circ} \mathrm{C}$. This catalyst support exhibited, similar to $\mathrm{K}-\mathrm{La}-\mathrm{ZrO}_{2}$ (Fig. 5.1), low activity for the steam reforming, with phenol conversion $\sim 10 \%$ at initial TOS. CO was observed as main product ( $\sim 16 \%$ yield). $\mathrm{H}_{2}\left(8 \%\right.$ yield) and $\mathrm{CO}_{2}$ (9\% yield) were produced to a lesser extent. $\mathrm{CH}_{4}$ was not present during reaction. $\mathrm{Ce}-\mathrm{ZrO}_{2}$ lost its activity rapidly, with phenol conversion decreasing from $\sim 10 \%$ to $\sim 3 \%$ after $1 \mathrm{~h}$ TOS. After this time, conversion and product yields leveled off.

Steam reforming of phenol over $\mathrm{Ni} / \mathrm{Ce}-\mathrm{ZrO}_{2}$ at $700{ }^{\circ} \mathrm{C}$ is shown in Fig. 5.4. This catalyst showed very high initial activity ( 80\% phenol conversion), just slightly lower than that observed over $\mathrm{Ni} / \mathrm{K}-\mathrm{La}-\mathrm{ZrO}_{2}$. Phenol was mainly converted to $\mathrm{H}_{2}$ and $\mathrm{CO}_{2}$, with yields around $88 \%$ and $79 \%$, respectively. $\mathrm{CO}$ was observed in small amounts $(\sim 21 \%$ yield $)$ and no $\mathrm{CH}_{4}$ was detected during the whole experiment. As regards to catalyst stability, the presence of nickel on $\mathrm{Ce}-\mathrm{ZrO}_{2}$ improved catalyst lifetime tremendously as evidenced by the reasonably stable phenol conversion throughout the experiment. Changes in product distribution during reaction occurred to a lesser extent as compared to $\mathrm{Ni} / \mathrm{K}-\mathrm{La}-\mathrm{ZrO}_{2} . \mathrm{H}_{2}$ and $\mathrm{CO}_{2}$ decreased from $85 \%$ to $71 \%$ and from $78 \%$ to $68 \%$, respectively, whereas $\mathrm{CO}$ remained fairly constant. 


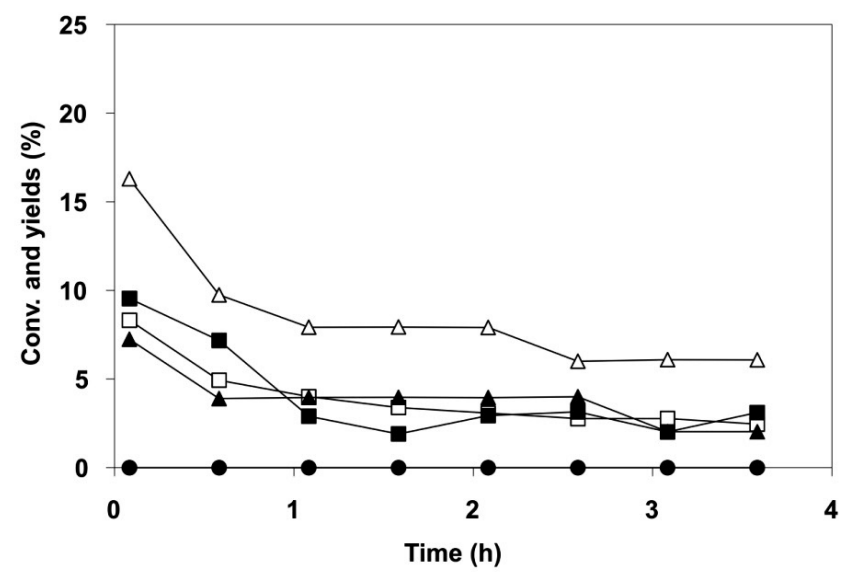

Fig. 5.3. Conversion and yields vs. time on stream for the steam reforming of phenol over $\mathrm{Ce}-\mathrm{ZrO}_{2}$. Reaction conditions: $700{ }^{\circ} \mathrm{C}, \mathrm{S} / \mathrm{C}=20, \mathrm{GHSV}=950000 \mathrm{~h}^{-1}$. (घ) phenol, ( $\left.\square\right) \mathrm{H}_{2},(\boldsymbol{\Delta}) \mathrm{CO}_{2},(\Delta) \mathrm{CO},(\bullet)$ $\mathrm{CH}_{4}$.

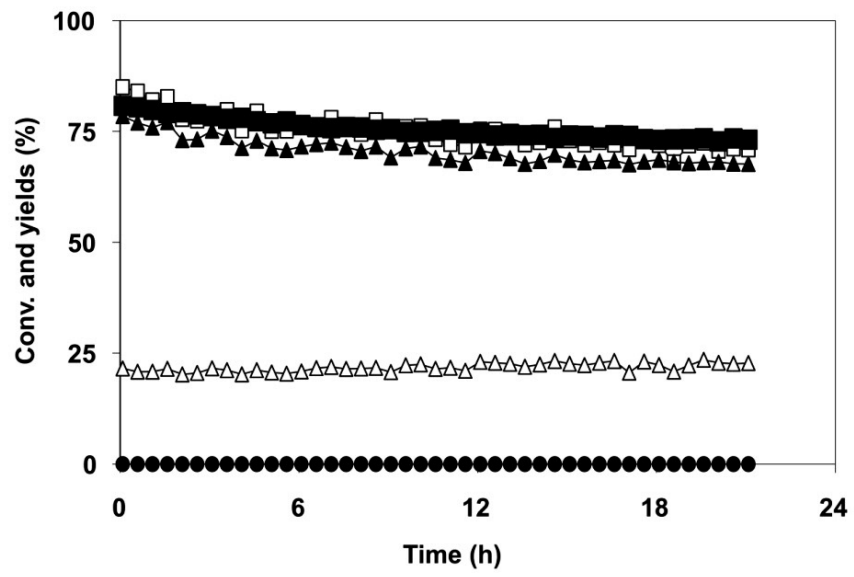

Fig. 5.4. Conversion and yields $v s$. time on stream for the steam reforming of phenol over $\mathrm{Ni} / \mathrm{Ce}-\mathrm{ZrO}_{2}$. Reaction conditions: $700{ }^{\circ} \mathrm{C}, \mathrm{S} / \mathrm{C}=20, \mathrm{GHSV}=950000 \mathrm{~h}^{-1}$. (घ) phenol, ( $\left.\square\right) \mathrm{H}_{2},(\boldsymbol{\Delta}) \mathrm{CO}_{2},(\Delta) \mathrm{CO},(\bullet)$ $\mathrm{CH}_{4}$.

\subsubsection{Steam reforming of phenol over unsupported nickel}

As shown in Fig. 5.5, approximately $16 \%$ phenol conversion was achieved when the steam reforming of phenol was carried out over unsupported nickel. Similar to the observations in the case of $\mathrm{K}-\mathrm{La}-\mathrm{ZrO}_{2}$ and $\mathrm{Ce}-\mathrm{ZrO}_{2}, \mathrm{CO}$ was the main gas product, with $\sim 32 \%$ yield at initial TOS and $\mathrm{H}_{2}(12 \%$ yield $)$ and $\mathrm{CO}_{2}(8 \%$ yield) were 
present in less significant amounts. Catalyst deactivation was noticed in the beginning of the reaction, as evidenced by the decrease in phenol conversion and gas product yields. After $3.5 \mathrm{~h}$ TOS, phenol conversion decreased by $\sim 50 \%$.

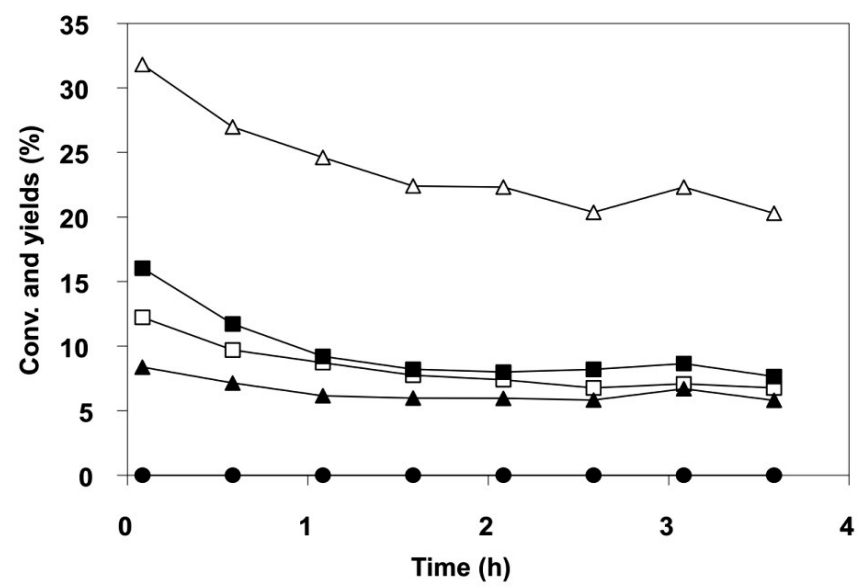

Fig. 5.5. Conversion and yields $v s$. time on stream for the steam reforming of phenol over Ni. Reaction conditions: $700{ }^{\circ} \mathrm{C}, \mathrm{S} / \mathrm{C}=20$, GHSV $=950000 \mathrm{~h}^{-1}$. (•) phenol, (口) $\mathrm{H}_{2},(\boldsymbol{\Delta}) \mathrm{CO}_{2},(\Delta) \mathrm{CO},(\bullet) \mathrm{CH}_{4}$.

\subsubsection{Water-gas shift reaction}

Fig. 5.6 compares $\mathrm{CO}$ conversion for the water-gas shift reaction at $700{ }^{\circ} \mathrm{C}$ over all the catalysts previously investigated for the steam reforming of phenol. It is clear from the figure that $\mathrm{Ni} / \mathrm{K}-\mathrm{La}-\mathrm{ZrO}{ }_{2}$ and $\mathrm{Ni} / \mathrm{Ce}-\mathrm{ZrO}_{2}$ showed the highest activity, with comparable $\mathrm{CO}$ conversions around 36\%. Unsupported nickel also showed high activity for the water-gas shift, with an initial CO conversion around $30 \%$. In contrast, both catalyst supports in the absence of nickel (K-La-ZrO $\mathrm{H}_{2}$ and $\mathrm{Ce}-\mathrm{ZrO}_{2}$ ) exhibited low activity. $\mathrm{CO}$ conversion was $\sim 8 \%$ over $\mathrm{K}-\mathrm{La}-\mathrm{ZrO}_{2}$ and $5.5 \%$ over $\mathrm{Ce}-\mathrm{ZrO}_{2}$. As regards to catalyst stability, all catalysts showed good stability except for unsupported nickel, which lost one third of its activity after $\sim 1 \mathrm{~h}$ TOS. After oxygen treatment at the same reaction temperature, the catalytic activity for the water-gas shift was recovered partially, indicating that coke deposition on the catalyst surface is not the only cause for catalyst deactivation. 


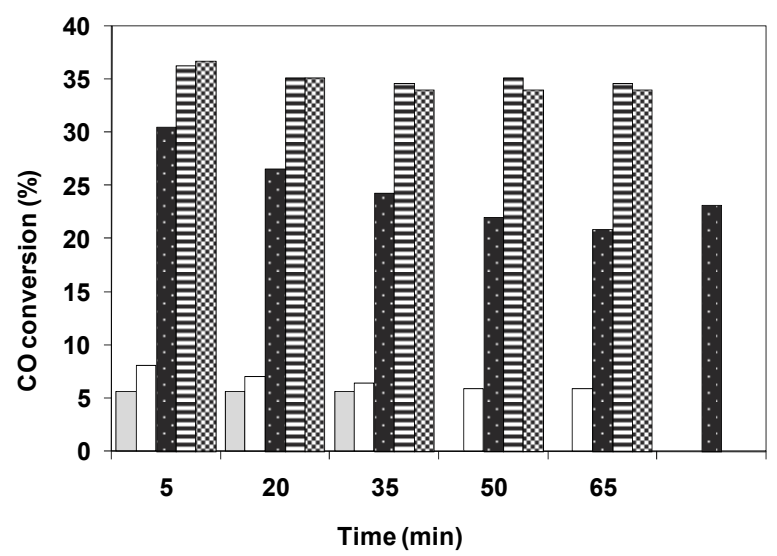

Fig. 5.6. $\mathrm{CO}$ conversion for the water-gas shift over $\mathrm{K}-\mathrm{La}-\mathrm{ZrO}{ }_{2}, \mathrm{Ni} / \mathrm{K}-\mathrm{La}-\mathrm{ZrO}{ }_{2}, \mathrm{Ce}-\mathrm{ZrO}{ }_{2}, \mathrm{Ni} / \mathrm{Ce}-\mathrm{ZrO}{ }_{2}$ and $\mathrm{Ni}$. Reaction conditions: $700{ }^{\circ} \mathrm{C}, \mathrm{S} / \mathrm{C}=0.54$, GHSV $=1036000 \mathrm{~h}^{-1}$. ( $\square$ ) $\mathrm{Ce}^{-\mathrm{ZrO}_{2}}$; (ㅁ) $\mathrm{K}-\mathrm{La}-\mathrm{ZrO}_{2}$; (ㅁ) unsupported Ni; (目) Ni/K-La-ZrO $;$; (圆) Ni/Ce-ZrO

Fig. 5.7 compares the $\left(\left[\mathrm{CO}_{2}\right]\left[\mathrm{H}_{2}\right] /[\mathrm{CO}]\left[\mathrm{H}_{2} \mathrm{O}\right]\right)$ ratio (corrected by phenol conversion) for the steam reforming of phenol at $700{ }^{\circ} \mathrm{C}$ over $\mathrm{Ni} / \mathrm{K}-\mathrm{La}-\mathrm{ZrO}_{2}$ and $\mathrm{Ni} / \mathrm{Ce}-\mathrm{ZrO}_{2}$ with the equilibrium constant for water-gas shift at the same reaction temperature. The significant lower $\left(\left[\mathrm{CO}_{2}\right]\left[\mathrm{H}_{2}\right] /[\mathrm{CO}]\left[\mathrm{H}_{2} \mathrm{O}\right]\right)$ ratio values obtained for both catalytic systems as compared to the equilibrium constant clearly indicate that the water-gas shift reaction is far away from equilibrium in both cases. It is also clear from the figure that $\mathrm{Ni} / \mathrm{Ce}-\mathrm{ZrO}_{2}$ deactivates for the water-gas shift to a lesser extent than $\mathrm{Ni} / \mathrm{K}-\mathrm{La}-\mathrm{ZrO}_{2}$.

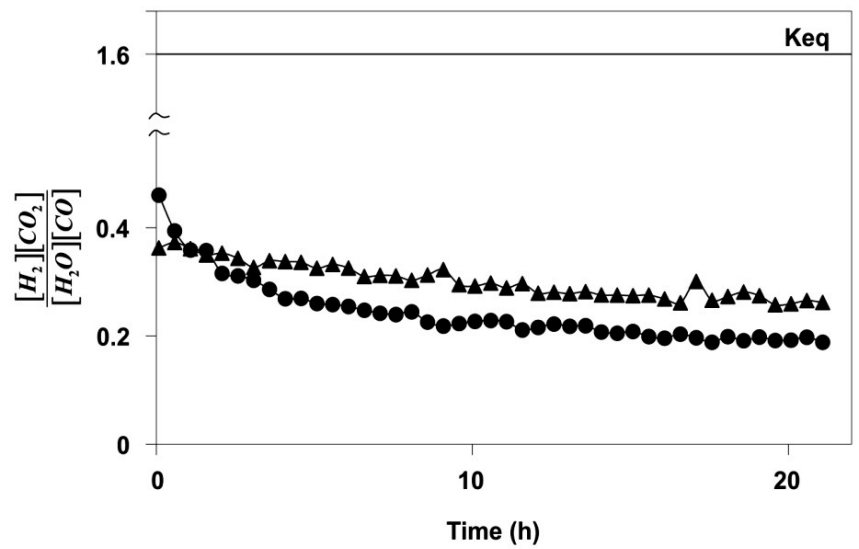

Fig. 5.7. Calculated $\left(\left[\mathrm{CO}_{2}\right]\left[\mathrm{H}_{2}\right]\right) /\left([\mathrm{CO}]\left[\mathrm{H}_{2} \mathrm{O}\right]\right)$ ratio corrected by the phenol conversion as a function of time on stream for the steam reforming of phenol over Ni/K-La-ZrO $\mathrm{Z}_{2}(\bullet)$ and $\mathrm{Ni} / \mathrm{Ce}-\mathrm{ZrO}_{2}(\boldsymbol{\Delta})$. Reaction conditions: $700^{\circ} \mathrm{C}, \mathrm{S} / \mathrm{C}=20$, GHSV $=950000 \mathrm{~h}^{-1}$. 


\subsubsection{Characterization of used catalysts}

Quantification and location of coke deposited on the catalysts during steam reforming of phenol at $700{ }^{\circ} \mathrm{C}$ was determined by TPO (Fig. 5.8). It is here appropriate to mention that TPO profiles were adjusted in intensity in order to be compared in one same figure. Thus, direct comparison of the different profiles cannot be done. TPO profile for $\mathrm{Ce}-\mathrm{ZrO}_{2}$ exhibited one well-defined peak with maximum at $335{ }^{\circ} \mathrm{C}$. The amount of coke accumulated on this catalyst support was 0.97 wt.\%. Similarly, TPO profile for $\mathrm{K}-\mathrm{La}-\mathrm{ZrO}_{2}$ displayed one single peak with maximum at $355{ }^{\circ} \mathrm{C}$. The amount of coke accumulated, 1.04 wt.\%, was comparable to that one

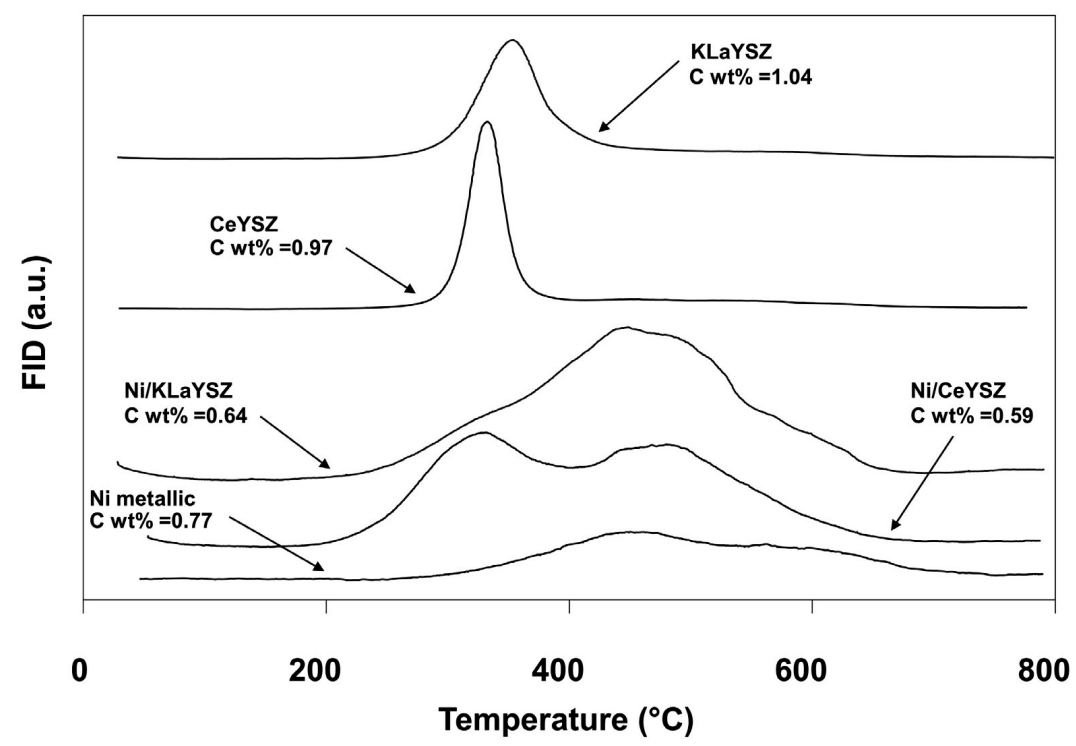

Fig. 5.8. Temperature program oxidation profiles of all used catalysts and the corresponding amount of deposited coke after (i) $3.5 \mathrm{~h}$ time on stream for $\mathrm{K}-\mathrm{La}-\mathrm{ZrO}_{2}, \mathrm{Ce}-\mathrm{ZrO}_{2}$ and $\mathrm{Ni}$ and (ii) $22 \mathrm{~h}$ time on stream for $\mathrm{Ni} / \mathrm{K}-\mathrm{La}-\mathrm{ZrO}_{2}$ and $\mathrm{Ni} / \mathrm{Ce}-\mathrm{ZrO}_{2}$.

deposited over $\mathrm{Ce}-\mathrm{ZrO}_{2}$. In the case of the unsupported nickel, two overlapped peaks were observed; centered at $\sim 460{ }^{\circ} \mathrm{C}$ and $\sim 590{ }^{\circ} \mathrm{C}$. Despite of lower surface area, this catalyst accumulated slightly larger amounts of coke (1.12 wt.\%), as compared to the catalyst supports, i.e. $\mathrm{K}-\mathrm{La}-\mathrm{ZrO}_{2}$ and $\mathrm{Ce}-\mathrm{ZrO}_{2}$. TPO profile of $\mathrm{Ni} / \mathrm{Ce}-\mathrm{ZrO}_{2}$ showed two broad overlapped peaks of comparable intensity, with maxima at $\sim 330{ }^{\circ} \mathrm{C}$ and $\sim 475{ }^{\circ} \mathrm{C}$. According to the TPO profiles of the individual components, the peak at $330{ }^{\circ} \mathrm{C}$ was assigned to coke deposited on $\mathrm{Ce}-\mathrm{ZrO}_{2}$ and the peak at higher temperature 
$\left(475^{\circ} \mathrm{C}\right.$ ) corresponded to coke located on the nickel surface. $\mathrm{Ni} / \mathrm{Ce}-\mathrm{ZrO}_{2}$ accumulated the lowest amount of coke $\left(0.59\right.$ wt.\%). As regards to $\mathrm{Ni} / \mathrm{K}-\mathrm{La}-\mathrm{ZrO}_{2}$, the TPO profile showed one main peak centered at $\sim 460{ }^{\circ} \mathrm{C}$ and two shoulder peaks, one at lower temperatures $\left(\sim 330^{\circ} \mathrm{C}\right)$ and the other one at higher temperatures $\left(590{ }^{\circ} \mathrm{C}\right)$. The shoulder at $\sim 330{ }^{\circ} \mathrm{C}$ was associated to coke deposited on $\mathrm{K}-\mathrm{La}-\mathrm{ZrO}_{2}$ whereas the two remaining peaks at higher temperatures were assigned to coke accumulated on the nickel surface. The amount of coke determined on $\mathrm{Ni} / \mathrm{K}-\mathrm{La}-\mathrm{ZrO}_{2}$ was comparable to that one observed on $\mathrm{Ni} / \mathrm{Ce}-\mathrm{ZrO}_{2}$. However, in contrast to the observations on $\mathrm{Ni} / \mathrm{Ce}-\mathrm{ZrO}_{2}$, coke deposits on $\mathrm{Ni} / \mathrm{K}-\mathrm{La}-\mathrm{ZrO}_{2}$ accumulated mainly $(\sim 4 / 5)$ on the nickel surface.

\subsection{Discussion}

In earlier publications $[13,17]$ we have shown that the design of a stable catalyst for the steam reforming of acetic acid, a major component in pyrolysis oil, is a key challenge in this process. We particularly reported [13] that the stability of a very active nickel-zirconia-based catalyst, affected negatively by the presence of coke deposits on the catalyst surface, is significantly improved by promoting the catalyst with small amounts of potassium and lanthanum. In this work, the catalytic performance of this potassium and lanthanum promoted nickel catalyst is evaluated for the steam reforming of phenol and it is compared to that of a new developed ceria-nickel-based catalyst.

The presence of $\mathrm{H}_{2}, \mathrm{CO}$ and $\mathrm{CO}_{2}$ during the steam reforming of phenol over $\mathrm{K}-\mathrm{La}-\mathrm{ZrO}_{2}$ (Fig. 5.1) and $\mathrm{Ce}-\mathrm{ZrO}_{2}$ (Fig. 5.3) suggests that both catalyst supports presented some steam reforming activity. However, both supports lost their initial activity rapidly. TPO experiments (Fig. 5.8) indicated that coke is accumulated on both supports in significant amounts, strongly suggesting that deactivation is essentially caused by the carbonaceous species formed during decomposition of phenol on the metal oxides. In the case of the catalytic steam reforming of phenanthrene [18], opening of the aromatic rings has been proposed as the first step in the formation of ring radicals which further react or condense to lead to coke on the catalyst surface. This aromatic ring-opening mechanism could also be applied in our phenol steam reforming case. 
Steam reforming products were also observed when the steam reforming reaction was carried out over unsupported nickel, indicating that nickel is able to activate both phenol and $\mathrm{H}_{2} \mathrm{O}$ (Fig. 5.5). This is in agreement with literature. On the one hand, nickel is known to dissociate water via formation of nickel oxide [10]. On the other hand, according to Russel et al. [19], phenol decomposition on nickel surfaces is initiated with the dissociation of the $\mathrm{O}-\mathrm{H}$ bond followed by ring-opening which can occur via two different mechanisms, as illustrated in Scheme 5.1, i.e. (i) $\mathrm{C}-\mathrm{H}$ scission coupled with $\mathrm{C}=\mathrm{C}$ rupture in positions 2 and 6 and (ii) dissociation of the $\mathrm{C}-\mathrm{O}$ bond, resulting in benzene which can be further decomposed via $\mathrm{C}=\mathrm{C}$ and C-H splitting. Both mechanistic routes result mainly in $\mathrm{H}_{2}, \mathrm{CO}$ and $\mathrm{C}_{\mathrm{x}} \mathrm{H}_{\mathrm{y}}$ species. In previous work on the steam reforming of acetic acid [20], we reported that acetic acid activation over Pt occurs via $\mathrm{C}-\mathrm{C}$ bond activation, producing $\mathrm{CO}_{2}$ and, similar to $\mathrm{CH}_{4}$ activation, forming $\mathrm{CH}_{\mathrm{x}}$ species $(0 \leq \mathrm{x} \leq 3)$ which could further be steam reformed in the presence of $\mathrm{H}_{2} \mathrm{O}$. Similarly, we propose that in the case of steam reforming of phenol, the $\mathrm{C}_{\mathrm{x}} \mathrm{H}_{\mathrm{y}}$ species generated during phenol decomposition on nickel will be the main species to be steam reformed. Steam reforming of aromatics such as benzene and naphthalene is feasible over nickel supported catalysts [15].<smiles>Oc1ccc(C=Cc2ccccc2)cc1</smiles><smiles>Oc1ccccc1-c1ccccc1</smiles>

Scheme 5.1. Proposed mechanistic routes for steam gasification of phenol over nickel-based catalysts. $\mathrm{C}=\mathrm{C}$ and $\mathrm{C}-\mathrm{H}$ cleavage (top); $\mathrm{C}-\mathrm{O}$ cleavage (bottom).

Similar to the observations obtained for the supports, $\mathrm{K}-\mathrm{La}-\mathrm{ZrO} \mathrm{r}_{2}$ and $\mathrm{Ce}-\mathrm{ZrO}_{2}$, the unsupported nickel deactivated with TOS. An oxidation treatment of this used catalyst revealed that large amounts of coke $(\sim 1.12 \mathrm{wt} . \%)$ deposited on the nickel surface, explaining, to a certain extent, catalyst deactivation. It is well establish [10] 
that nickel-based catalysts suffer from severe coking during steam reforming. Therefore, it is in agreement with our results. Besides coking, sintering of the nickel particles is an additional explanation for catalyst deactivation. During water-gas shift reaction over unsupported nickel at $700{ }^{\circ} \mathrm{C}$ (Fig. 5.6) it was observed that catalyst lost its activity significantly. An oxidation treatment at the same temperature retrieved catalyst activity to a little extent, indicating that at $700{ }^{\circ} \mathrm{C}$ unsupported nickel suffered from sintering to a reasonable extent. Therefore, it can be assumed that during steam reforming of phenol over unsupported nickel at the same reaction temperature, part of the observed deactivation is due to catalyst sintering.

The catalytic activity of the two supported nickel catalysts, namely $\mathrm{Ni} / \mathrm{K}-\mathrm{La}-\mathrm{ZrO}_{2}$ (Fig. 5.2) and $\mathrm{Ni} / \mathrm{Ce}-\mathrm{ZrO}_{2}$ (Fig. 5.4), was certainly improved, as compared to the unsupported nickel. This was evidenced by the high phenol conversion $(\sim 85-90 \%)$ obtained even at the extremely high space velocities applied in this study. Two hypotheses could explain these observations: (i) the number of available nickel active sites and (ii) the role of the support in the mechanism for steam reforming.

In the case of unsupported nickel (i), the corresponding metal clusters were larger ( $\sim 3$ times) than those obtained for the supported nickel catalysts, resulting in less number of available nickel active sites and thus, lower activity. On the other hand, the presence of the support (ii) can play an important role. In an earlier study [21] on the steam reforming of acetic acid over supported platinum catalysts, we have proposed a bifunctional mechanism, where both $\mathrm{Pt}$ and support participate in the conversion of acetic acid $(\mathrm{AcOH})$ towards syngas production. In this work, even though unsupported nickel as well as catalyst supports present some steam reforming activity, bifunctionality of the nickel catalysts could also explain the significant higher steam reforming activity of the supported nickel catalysts as compared to the unsupported catalysts.

As regards to catalyst lifetime, both $\mathrm{Ni} / \mathrm{K}-\mathrm{La}-\mathrm{ZrO}_{2}$ (Fig. 5.2) and $\mathrm{Ni} / \mathrm{Ce}-\mathrm{ZrO}_{2}$ (Fig. 5.4) exhibited excellent stability in terms of phenol conversion. However, $\mathrm{Ni} / \mathrm{K}-\mathrm{La}-\mathrm{ZrO}_{2}$ showed a substantial change in gas product distribution with TOS, suggesting water-gas shift deactivation, which was much less pronounced in the case 
of $\mathrm{Ni} / \mathrm{Ce}-\mathrm{ZrO}_{2}$. Comparison between the $\left(\left[\mathrm{CO}_{2}\right]\left[\mathrm{H}_{2}\right] /[\mathrm{CO}]\left[\mathrm{H}_{2} \mathrm{O}\right]\right)$ ratio calculated for both catalysts during the steam reforming of phenol, as shown in Fig. 5.7, confirms that $\mathrm{Ni} / \mathrm{K}-\mathrm{La}-\mathrm{ZrO}_{2}$ deactivated to a larger extent for the water-gas shift as compared to $\mathrm{Ni} / \mathrm{Ce}-\mathrm{ZrO}_{2}$. This difference in water-gas shift deactivation can be explained by the combination of two results: (i) TPO measurements of the used catalysts and (ii) detailed studies on the water-gas shift reaction. On the one hand, TPO results revealed that $\mathrm{Ni} / \mathrm{K}-\mathrm{La}-\mathrm{ZrO}_{2}$ and $\mathrm{Ni} / \mathrm{Ce}-\mathrm{ZrO}_{2}$ accumulated comparable amounts of carbonaceous deposits (Fig. 5.8). However, the location of these deposits was very different. In the case of $\mathrm{Ni} / \mathrm{K}-\mathrm{La}-\mathrm{ZrO}_{2}$, deposits accumulated mainly on the nickel surface $(\sim 4 / 5)$; only a small part of the $\mathrm{K}-\mathrm{La}-\mathrm{ZrO}_{2}$ support was covered with deposits. In contrast, coke on $\mathrm{Ni} / \mathrm{Ce}-\mathrm{ZrO}_{2}$ was evenly distributed over the metal and support surface. Approximately half of the deposits were located on the nickel surface and the other half on the metal oxide $\left(\mathrm{Ce}-\mathrm{ZrO}_{2}\right)$. On the other hand, the kinetic results obtained during the water-gas shift reaction over all the catalytic systems investigated (Fig. 5.6) clearly showed that unsupported nickel exhibited much higher activity than the catalyst supports, i.e. $\mathrm{K}-\mathrm{La}-\mathrm{ZrO}_{2}$ and $\mathrm{Ce}-\mathrm{ZrO}_{2}$. These kinetic results indicate the essential role of nickel in dissociating $\mathrm{CO}$ and $\mathrm{H}_{2} \mathrm{O}$ and suggest that water-gas shift occurred mainly on the nickel surface. The occurrence of water-gas shift over unsupported nickel (e.g. Ni (100) surfaces) has been earlier stated in literature [22], in line with our observations. Surface characterization with XPS showed that the presence of metal impurities in the nickel surface was small (Table 5.2), excluding thus, any significant contribution of these impurities to the water-gas shift activity observed over the unsupported nickel.

Based on our results and discussion, the difference in catalyst stability between $\mathrm{Ni} / \mathrm{Ce}-\mathrm{ZrO}_{2}$ and $\mathrm{Ni} / \mathrm{K}-\mathrm{La}-\mathrm{ZrO}_{2}$ can be explained by the location of the carbonaceous deposits on the catalyst surface and the excellent activity of nickel for the water-gas shift, as illustrated in Scheme 5.2. Further, the nature of the support is responsible for the difference in the location of carbonaceous deposits and in turn the difference in catalyst stability. It is well established [23] that ceria has excellent oxygen exchange capacity involving red-ox changes between $\mathrm{Ce}^{4+}$ and $\mathrm{Ce}^{3+}$. In this context, Polychronopoulou et al. [24] have recently reported the occurrence of back-spillover 
of labile $\mathrm{OH}$ and $\mathrm{O}$ species from the support to the metal during steam reforming of phenol over a ceria-based catalyst (e.g. Rh/Mg-Ce-Zr-O). Accordingly, back-spillover
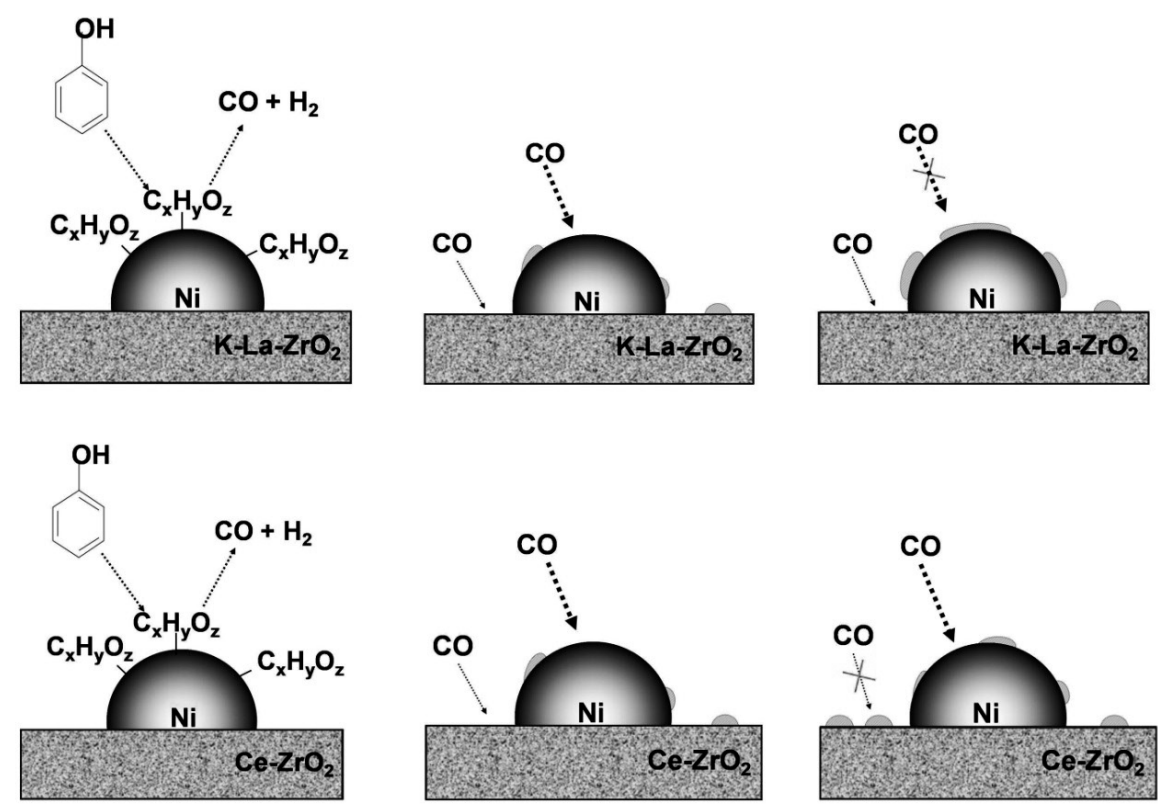

Scheme 5.2. Proposed explanation for the difference in catalyst stability between $\mathrm{Ni} / \mathrm{K}-\mathrm{La}-\mathrm{ZrO}_{2}$ and $\mathrm{Ni} / \mathrm{Ce}-\mathrm{ZrO}_{2}$.

of such oxygenated species from the $\mathrm{Ce}-\mathrm{ZrO}_{2}$ support to the nickel surface is also expected in this study. The presence of these oxygenate species on the nickel surface could result in gasification of carbonaceous deposits accumulated on the nickel and that would explain why most of the nickel surface remains clean. In contrast, in the case of $\mathrm{Ni} / \mathrm{K}-\mathrm{La}-\mathrm{ZrO}_{2}$, the support does not possess red-ox properties and therefore, only $\mathrm{OH}$ species are expected to be able to undergo back-spillover. As a result, the carbonaceous deposits accumulated on the nickel surface could be gasified to a lesser extent as compared to $\mathrm{Ni} / \mathrm{Ce}-\mathrm{ZrO}_{2}$.

To summarize, this work shows the excellent catalytic performance of $\mathrm{Ni} / \mathrm{Ce}-\mathrm{ZrO}_{2}$ in the steam reforming of phenol and shows promise for the steam reforming of the whole fraction of biomass-derived pyrolysis oil. 


\subsection{Conclusions}

This work has shown that $\mathrm{Ni} / \mathrm{K}-\mathrm{La}-\mathrm{ZrO}_{2}$ and $\mathrm{Ni} / \mathrm{Ce}-\mathrm{ZrO}_{2}$ are very active catalysts for the steam reforming of heavy oxygenates present in pyrolysis oil. However, $\mathrm{Ni} / \mathrm{K}-\mathrm{La}-\mathrm{ZrO}_{2}$ deactivates for the water-gas shift to a larger extent than $\mathrm{Ni} / \mathrm{Ce}-\mathrm{ZrO}_{2}$, affecting negatively its stability. The high activity of the nickel surface for the water-gas shift in combination with the location of coke on the catalyst support are suggested to be key to explain the difference in water-gas shift deactivation between the two catalysts. Further, the use of a support with red-ox properties allows the nickel surface to remain clean from carbonaceous deposits and this explains the difference in the location of these deposits between $\mathrm{Ni} / \mathrm{K}-\mathrm{La}-\mathrm{ZrO}{ }_{2}$ and $\mathrm{Ni} / \mathrm{Ce}-\mathrm{ZrO}_{2}$. 


\section{References}

[1] P. Azadi, K.M. Syed, and R. Farnood, Applied Catalysis A: General 358 (2009) 65-72.

[2] G. van Rossum, S.R.A. Kersten, and W.P.M. van Swaaij, Industrial \& Engineering Chemistry Research 46 (2007) 3959-3967.

[3] C. Rioche, S. Kulkarni, F.C. Meunier, J.P. Breen, and R. Burch, Applied Catalysis B: Environmental 61 (2005) 130-139.

[4] K. Nakamura, T. Miyazawa, T. Sakurai, T. Miyao, S. Naito, N. Begum, K. Kunimori, and K. Tomishige, Applied Catalysis B: Environmental 86 (2009) 36-44.

[5] K. Sato, and K. Fujimoto, Catalysis Communications 8 (2007) 1697-1701.

[6] K. Polychronopoulou, A. Bakandritsos, V. Tzitzios, J.L.G. Fierro, and A.M. Efstathiou, Journal of Catalysis 241 (2006) 132-148.

[7] K. Polychronopoulou, J.L.G. Fierro, and A.M. Efstathiou, Journal of Catalysis 228 (2004) 417-432.

[8] C. Li, and K. Suzuki, Renewable and Sustainable Energy Reviews 13 (2009) 594-604.

[9] D. Swierczynski, S. Libs, C. Courson, and A. Kiennemann, Applied Catalysis B: Environmental 74 (2007) 211-222.

[10] J.R. Rostrup-Nielsen, Catalysis: Science and Technology 5 (1984) 1-117.

[11] X.E. Verykios, International Journal of Hydrogen Energy 28 (2003) 1045-1063.

[12] U. Olsbye, O. Moen, A. Slagtern, and I.M. Dahl, Applied Catalysis A: General 228 (2002) 289-303.

[13] B. Matas Güell, I.M.T.d. Silva, K. Seshan, and L. Lefferts, Applied Catalysis B: Environmental 88 (2009) 59-65.

[14] D.A. Constantinou, and A.M. Efstathiou, Catalysis Today 143 (2009) 17-24.

[15] T. Furusawa, Y. Miura, Y. Kori, M. Sato, and N. Suzuki, Catalysis Communications 10 (2009) 552-556.

[16] O. Sidjabat, and D.L. Trimm, Topics in Catalysis 11-12 (2000) 279-282.

[17] B. Matas Güell, I. Babich, K.P. Nichols, J.G.E. Gardeniers, L. Lefferts, and K. Seshan, Applied Catalysis B: Environmental 90 (2009) 38-44.

[18] J. Corella, M.A. Caballero, M.-P. Aznar, and C. Brage, Industrial \& Engineering Chemistry Research 42 (2003) 3001-3011.

[19] J.N. Russell, S.S. Sarvis, and R.E. Morris, Surface Science 338 (1995) 189-203. 
[20] K. Takanabe, K.-i. Aika, K. Inazu, T. Baba, K. Seshan, and L. Lefferts, Journal of Catalysis 243 (2006) 263-269.

[21] P. Liu, J.A. Rodriguez, Y. Takahashi, and K. Nakamura, Journal of Catalysis 262 (2009) 294-303.

[22] K. Nagaoka, K. Seshan, K. Takanabe, and K.-i. Aika, Catalysis Letters 99 (2005) 97-100.

[23] K. Polychronopoulou, C.N. Costa, and A.M. Efstathiou, Catalysis Today 112 (2006) 89-93. 



\section{Chapter 6}

\section{Evaporation of pyrolysis oil: product distribution and residue char analysis}

Formation of char during pyrolysis oil evaporation cannot be avoided. The pyrolysis oil char, which ages when subjected to elevated temperatures $\left(\geq 700{ }^{\circ} \mathrm{C}\right)$, shows similar reactivity towards combustion and steam gasification as compared to chars produced during fast pyrolysis of solid biomass. However, their structure is very different; pyrolysis oil char is very light and fluffy. The steam gasification rate for char is too low at the preferred temperature regime $\left(<700^{\circ} \mathrm{C}\right)$ required for pyrolysis oil evaporation. To be able to use the produced char in conversion processes (energy or syngas production) char will have to be anchored to a catalytic carrier. 



\subsection{Introduction}

Syngas production from biomass can play an important role for producing renewable fuels and chemicals especially when waste streams are being considered. For logistics and processing advantages, pyrolysis oil is proposed to become an intermediate energy carrier as the new 'crude oil' for refining [1,2].

To convert pyrolysis oil to syngas/hydrogen, which is the basis for the production and upgrading (hydrogen) of many fuels and chemicals, catalytic steam reforming is considered as a very attractive route since moderate process conditions can be applied and different scale sizes can be used as compared to high temperature entrained flow gasification [3].

When pyrolysis oil is being catalytically steam reformed, it is always accompanied by thermal reactions such as gasification and cracking. Already during the evaporation of the pyrolysis oil, three different products can be identified, namely: permanent gases, vapors and a carbonaceous solid material (here called char). Especially due to char formation, steam reforming of pyrolysis oil is preferred in a fluidized bed $[3,4]$, as clogging of the reactor can be avoided. The char particles are then evenly distributed into the bed or elutriated from the bed.

Various groups $[3,4,5,6]$ have steam reformed pyrolysis oil or its fractions in a single fluidized catalytic bed where in most cases, a relatively clean fuel gas was produced. However, irreversible catalytic activity loss (leading to increasing methane levels), which has mostly been ascribed to attrition/sintering of the catalyst, was observed. Another problem when using a single reactor is that optimization of the evaporation of pyrolysis oil is limited because the reforming catalyst needs a higher temperature to produce a methane free syngas at higher pressures due to the chemical equilibrium [7]. To overcome these problems, which limit the applicability of the process, Van Rossum et al. [3, 7, 8] proposed a staged reactor concept where the evaporation and catalytic conversion are decoupled using a fluidized bed for oil evaporation followed by a fixed-bed which contains a steam reforming catalyst. In this way, optimization of both processes, essentially different, is possible. A clean syngas could be produced when both the fluidized and fixed-bed were at a temperature $\sim 800{ }^{\circ} \mathrm{C}$. A decrease of the evaporation temperature allowed the catalyst 
to actually 'see' primary tars (oxygenated pyrolysis vapors) which are easier to reform instead of a thermally cracked gas. This is very relevant, as most of the works reported in literature address steam reforming of oxygenates present in pyrolysis oil. To have a high overall efficiency of the process, all char has to be converted in the process instead of partly being considered as a loss. For this, two options seem likely: (i) char is either combusted in a separated combustor to supply heat for the endothermic steam reforming reactions and evaporation or (ii) char is kept in the reactor and gasified using steam and/or $\mathrm{CO}_{2}$. An efficiency evaluation [7] showed that internal gasification is preferable. Additionally, this option would also allow an easier process operation; external heating is easier to control than maintaining a heat carrier circulation, especially at elevated pressures.

To get more insight in the char produced during evaporation of pyrolysis oil, the process is isolated and studied in this paper. Initially, the produced chars are evaluated on its general properties, reactivity and shape. Further, the results are discussed on what kind of implications they have on designing a process for steam reforming of pyrolysis oil.

\subsection{Experimental}

\subsubsection{Materials}

The pyrolysis oil was produced in the Process Development Unit of VTT, Finland [9]. Forest residue was used as biomass source. Activated carbon was obtained from Norit. The corresponding elemental analyses and water determinations are given in Table 6.1. Wood pyrolysis char was produced in our own facilities.

Table 6.1. Elemental analyses (wet) and water content determinations of the forest residue pyrolysis oils and chars used. The term rest is mainly oxygen with also compounds like sulfur, nitrogen and ash. (n.d.) not determined.

$$
\text { C(wt.\%) } \quad \mathrm{H}\left(\text { wt.\%) } \quad \text { Rest(wt.\%) } \quad \mathrm{H}_{2} \mathrm{O}(\text { wt.\%) }\right.
$$

\begin{tabular}{lcccc}
\hline Pyrolysis oil & 40.6 & 7.6 & 51.8 & 23.9 \\
Wood pyrolysis char & 88.7 & 2.5 & 7.5 & n.d. \\
Activated carbon & 85.9 & 0.6 & 13.5 & n.d. \\
\hline
\end{tabular}




\subsubsection{Continuous pyrolysis oil evaporation: product distribution}

A dedicated continuous pyrolysis evaporation set-up was constructed to quantify the distribution of pyrolysis oil during evaporation between the gas, vapor and char phase. A schematic overview of the set-up is given in Fig. 6.1. Pyrolysis oil (FR $100 \mathrm{ml} \cdot \mathrm{h}^{-1}$, duration ca. $1 \mathrm{~h}$; referred as $\mathrm{C}_{\text {in_oil }}$ ) was sprayed into an empty electrically heated stainless steel tube (Ø $40 \mathrm{~mm}$, length $400 \mathrm{~mm}$ ) using a cooled ultrasonic atomizer (LecherUS1, spraying angle $30^{\circ}$ ). Two thermocouples were

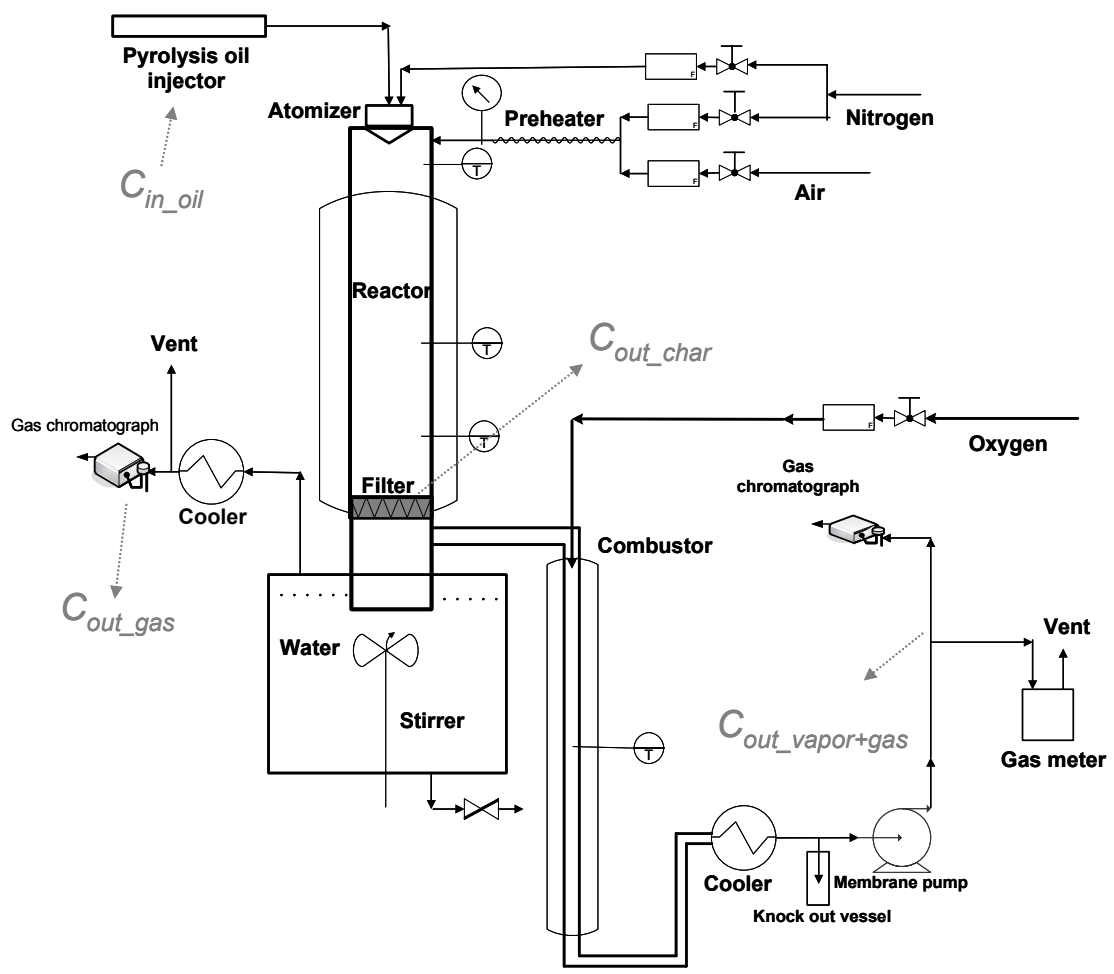

Fig. 6.1. Schematic overview of the continuous pyrolysis evaporation set-up for measuring the carbon distribution from the oil to gas, vapor and char. The amount of gas and char are measured directly, the vapor amount is calculated by difference.

placed inside the reactor to record the actual temperature in the middle of the reactor during evaporation experiments. The reported reactor temperatures are averaged values of the two thermocouples over the whole experiment. The reactor temperature was varied between $\sim 500-845^{\circ} \mathrm{C}$. The largest droplets created by the atomizer were 88-117 $\mu \mathrm{m}$ size (assisting gas $\mathrm{N}_{2} 4.01 \cdot \mathrm{min}^{-1}$ ), as measured with a high speed camera (Photron Fastcam SA1). However, most of the droplets were much smaller, below the 
resolution limit of the camera. Additional preheated $\mathrm{N}_{2}$ was added directly under the atomizer in a circular way to avoid vapor condensation on the cooler of the atomizer and to keep the residence time of the gases around 2-3 s over the temperature range measured. A filter (mesh size $5 \mu \mathrm{m}$ ) together with a small sand layer was placed at the end of the evaporation chamber to avoid high pressure drop (maximal 0.3 bar). The temperature of the filter was always lower than the reactor temperature $\left(498-665^{\circ} \mathrm{C}\right)$. After the filter, the stream was split into two streams. One of them was connected to a combustor where the produced gas/vapor mixture was totally combusted with pure oxygen producing $\mathrm{CO}_{2}$ and $\mathrm{H}_{2} \mathrm{O}$. This gas flow was kept constant with a membrane pump which was placed after a condenser. The other filter was directly fed to a quenching water bath which was mechanically stirred to quickly cool the gas/vapor mixture and trap the condensables. Two micro-GC's (2x Varian CP-4900; detecting $\mathrm{N}_{2}, \mathrm{H}_{2}, \mathrm{CH}_{4}, \mathrm{CO}, \mathrm{CO}_{2}, \mathrm{C}_{2} \mathrm{H}_{4}, \mathrm{C}_{2} \mathrm{H}_{6}, \mathrm{C}_{3} \mathrm{H}_{6}$ and $\mathrm{C}_{3} \mathrm{H}_{8}$ ) measured the gas composition of the combustor $\left(\mathrm{C}_{\text {out_vapor+gas }}\right)$ and of the quench stream $\left(\mathrm{C}_{\text {out_gas }}\right)$. The nitrogen fed to the evaporated was used as internal standard to calculate the integral carbon balance. After an experiment, the char on the filter was either collected for analysis and reactivity testing or it was combusted $\left(\mathrm{C}_{\text {out_char }}\right)$ to make a total carbon balance over the system. The carbon to gas ratios and char conversions are measured directly and the carbon to vapor conversion is calculated by the difference between the combustor and quench streams according to:

$$
C_{\text {out_vapor }}=C_{\text {out_gas+vapor }}-C_{\text {out_gas }}
$$

Distribution:

$$
\operatorname{Gas}(\%)=100 \frac{C_{\text {out_gas }}}{C_{\text {in_oil }}} \quad \operatorname{Vapor}(\%)=100 \frac{C_{\text {out_vapor }}}{C_{\text {in_oil }}} \quad \operatorname{Char}(\%)=100 \frac{C_{\text {out_char }}}{C_{\text {oil_ }} \text { in }}
$$

The carbon closure of the three different sections was found to be adequate: (i) Gas only: $101 \pm 1 \%$ based on methane addition and recovery in both the combustor and gas+vapor line, (ii) Gas + vapor: acetic acid was evaporated and partially thermally cracked $\left(\mathrm{T} \sim 720-750{ }^{\circ} \mathrm{C}, \mathrm{S} / \mathrm{C} \sim 2.5-5.0\right)$. Here, no char is being formed: carbon recovery $96 \pm 1 \%$, (iii) Solid: wood pyrolysis char was combusted 
with a carbon recovery of $97 \pm 2 \%$. The carbon recovery of all the pyrolysis oil evaporation experiments (gas + vapor + solid) was $98 \pm 4 \%$.

\subsubsection{Combustion of char}

Combustion experiments were performed in a Mettler Toledo thermogravimetric analyzer (TGA). The samples were heated to $800{ }^{\circ} \mathrm{C}$ at a rate of $5{ }^{\circ} \mathrm{C} \cdot \mathrm{min}^{-1}$ in a mixture of air $\left(20 \mathrm{ml} \cdot \mathrm{min}^{-1}\right)$ and $\operatorname{argon}\left(40 \mathrm{ml} \cdot \mathrm{min}^{-1}\right)$. Additional to the TGA balance ( $1 \mu \mathrm{g}$ sensitivity), the overall weight loss of the sample was quantified with a very accurate external balance $(0.01 \mu \mathrm{g}$ sensitivity) since some weight loss was already observed during the stabilization time of the TGA. Two different weight rate losses are defined:

$$
\begin{aligned}
& r_{w T} \equiv \frac{d X}{d T}=-\frac{\left(m_{\tau}-m_{\tau+1}\right)}{m_{0}\left(T_{\tau}-T_{\tau+1}\right)} \quad\left({ }^{\circ} \mathrm{C}^{-1}\right) \\
& r_{w t} \equiv \frac{d X}{d t}=-\frac{\left(m_{\tau}-m_{\tau+1}\right)}{m_{0}\left(t_{\tau}-t_{\tau+1}\right)} \quad\left(\mathrm{s}^{-1}\right)
\end{aligned}
$$

where $\tau$ and $\tau+1$ are logged times, $\mathrm{T}\left({ }^{\circ} \mathrm{C}\right)$ the temperature of the sample cup and $\mathrm{m}_{0}(\mathrm{mg})$ the initial amount of pyrolysis oil as weighted with the external balance. The overall char weight conversions $(\mathrm{X})$ and carbon to char conversions were calculated using the external balance.

\subsubsection{Steam gasification of char}

A quartz tube (Ø $45 \mathrm{~mm}$, length $400 \mathrm{~mm}$ ) which was placed inside an electrically heated oven was used. A steam generator was used to create a steady steam flow $\left(\sim 300{ }^{\circ} \mathrm{C}, 0.15-0.5 \mathrm{~g} \cdot \mathrm{min}^{-1}\right)$ and preheated nitrogen $\left(\sim 200{ }^{\circ} \mathrm{C}, 9 \mathrm{ml} \cdot \mathrm{min}^{-1}\right)$ was added as internal standard. The amount of steam added compared to the char sample (ca. 4-10 mg) was high enough to obtain steam conversions below $1 \%$. The char sample was placed at the end of the oven to ensure adequate preheating of the steam/nitrogen and allow isothermal gasification. The char sample to be gasified was pre-mixed with quartz $(0.2-0.6 \mathrm{~g})$ to lower the pressure drop which can be created due to the fine structure of the char. The mixed sample (ca. $1 \mathrm{~cm}$ in length) was fixed with quartz wool in the upper part of the heated quartz tube. Some pressure drop (0.2-0.5 bar) over the sample was observed. The reactor outlet was cooled and all the 
steam was condensed out completely. A micro-GC (Varian CP-4900) was used to analyze the gas composition from which the carbon conversion was calculated.

\subsection{Results and discussion}

\subsubsection{Continuous pyrolysis oil evaporation: product distribution}

Fig. 6.2 shows the carbon distribution to permanent gas, vapor and solid phase using forest residue pyrolysis oil. The amount of char produced seems to be rather constant ( $\sim 8 \%$ on carbon basis) over the whole temperature ranged measured. This indicates that (i) pyrolysis oil evaporation is always coupled with char formation and (ii) the initial distribution between char and vapors/gases is apparently already attained in the temperature trajectory up to $500{ }^{\circ} \mathrm{C}$, in line with earlier work $[7,12]$. The vapor production decreases with increasing temperature and the amount of gases increases opposite to the vapor production, suggesting that the main conversion pathway for gas production is via vapor cracking.

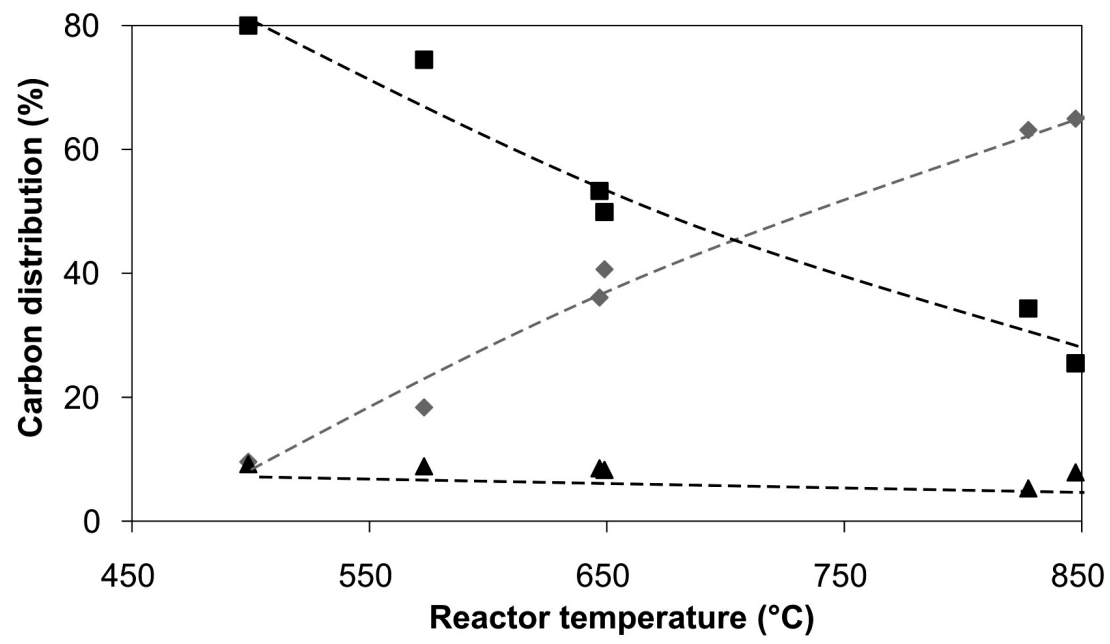

Fig. 6.2. Carbon distribution over the gas, vapor and solid (char) phase during the evaporation of FR pyrolysis oil using an ultrasonic at a pyrolysis oil feeding rate of $100 \mathrm{ml} \cdot \mathrm{min}^{-1}$. (ロ) Vapor; $(\diamond)$ Gas; ( $\mathbf{\Lambda})$ Char.

\subsubsection{Structural analysis of char}

From the chars produced, pyrolysis oil char produced at $525{ }^{\circ} \mathrm{C}$ ((wt\%): C: 76.7, H: 3.4, Rest: 19.9) was chosen for further analysis, as combustion 
reactivity measurements showed that this char is among the most reactive. Fig. 6.3 shows Scanning Electron Microscope (SEM) photos of this char. The char consists mostly of hollow spheres, with wall thickness of a few hundred nm, which have been ruptured. Smaller particles are deposited onto and into these larger structures. The largest sizes of the spheres (around $100 \mu \mathrm{m}$ ) are in the same size range as the largest pyrolysis oil droplets $(88-117 \mu \mathrm{m})$ which were photographed with the high speed camera. The spheres seem to be similar to the glassy/cenosphere solids produced during pyrolysis oil evaporation and/or combustion $[13,15]$. Overall, the char is very light/fluffy as compared to char produced during fast pyrolysis of wood and that explains why elutriation of this char occurs to a large extent in a fluidized bed.
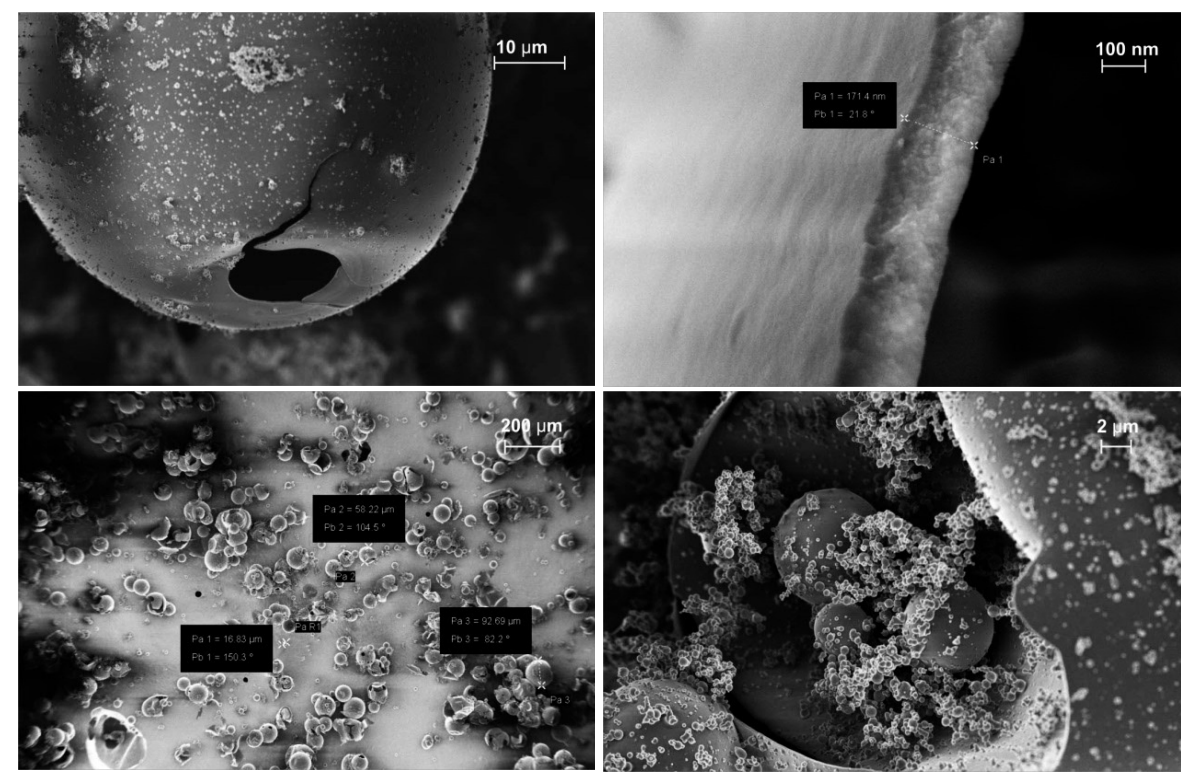

Fig. 6.3. SEM photos of char produced at $525{ }^{\circ} \mathrm{C}$ using an ultrasonic atomizer and deposited in the continuous pyrolysis oil droplet evaporation set-up.

\subsubsection{Char combustion}

Fig. 6.4 shows the reactivity profiles for the combustion of char samples as a function of temperature. The reactivity of two different types of carbon containing materials, namely char from fast pyrolysis (wood pyrolysis char) and activated carbon is compared in Fig. 6.4a. The former, which is known to have a high reactivity, presented a combustion peak around $500{ }^{\circ} \mathrm{C}$ whereas the latter resulted in a main peak 
centered around $645^{\circ} \mathrm{C}$, indicating its higher stability as compared to wood pyrolysis char. This result reveals that reactivity of char is influenced by its composition.

Fig. $6.4 \mathrm{~b}$ shows the reactivity profile for the combustion of char produced in the continuous pyrolysis oil evaporation set-up at different temperatures and collected from the installed filter (see Fig. 6.1). Chars produced at $525{ }^{\circ} \mathrm{C}$ and $654{ }^{\circ} \mathrm{C}$ presented similar reactivity as evidenced by the similar temperature $\left(\sim 450{ }^{\circ} \mathrm{C}\right)$ at which both chars were combusted. In contrast, char produced at higher temperatures $\left(844{ }^{\circ} \mathrm{C}\right)$ presented a peak centered $\sim 550{ }^{\circ} \mathrm{C}$, indicating that this char is less reactive. This clearly indicates that, besides char composition, the temperature at which char has been produced has a significant influence on the reactivity.
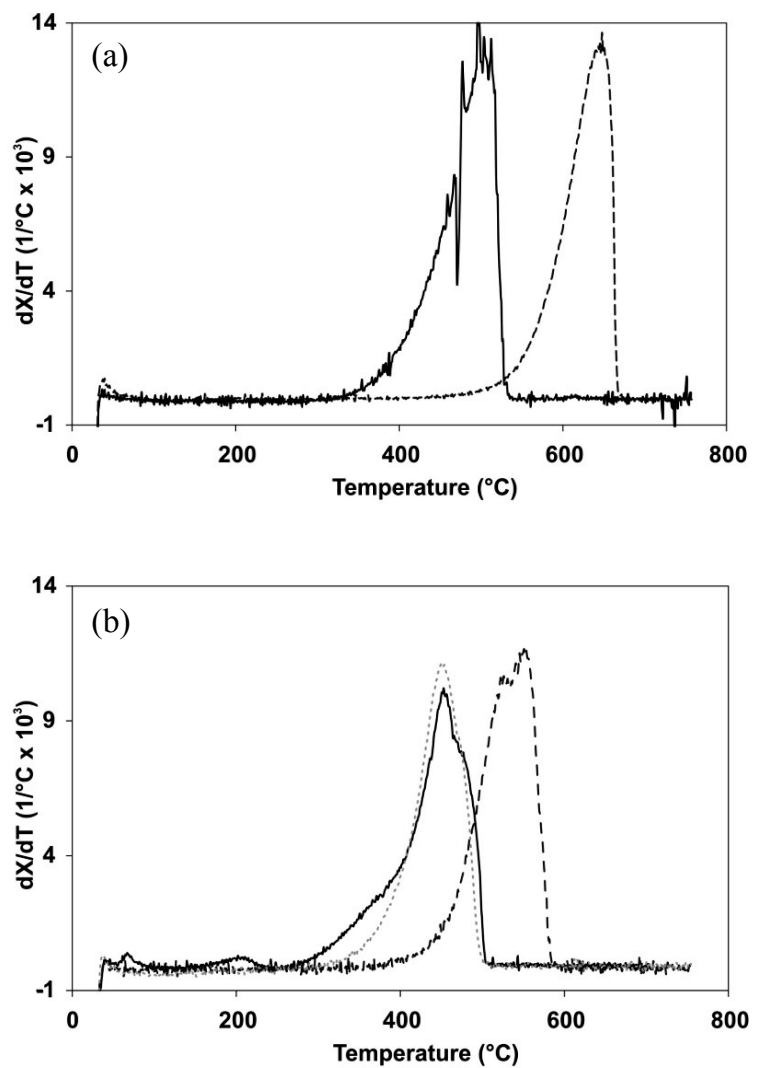

Fig. 6.4. (a) Combustion profiles for char from fast pyrolysis (_) and of activated carbon (.....). (b) Combustion profiles of char formed in the continuous evaporation set-up which was operated at $525{ }^{\circ} \mathrm{C}(\ldots), 654{ }^{\circ} \mathrm{C}(\ldots .$.$) and 844{ }^{\circ} \mathrm{C}(\ldots$ _ $)$. Heating rate: $5^{\circ} \mathrm{C} \cdot \mathrm{min}^{-1}$, air flow: $20 \mathrm{ml} \cdot \mathrm{min}^{-1}$, argon flow: $40 \mathrm{ml} \cdot \mathrm{min}^{-1}$. 
Another important aspect to stress is that the reactivity of the chars produced during pyrolysis oil evaporation is comparable to the high reactivity observed for wood fast pyrolysis char. In contrast, Branca et al. [17] reported that reactivity of pyrolysis oil char was lower than those of wood pyrolysis char. This difference is most likely due to the different char production methods (cup heating vs. atomization).

\subsubsection{Char steam gasification}

Besides combustion, the reactivity of char produced at $525^{\circ} \mathrm{C}$ towards steam gasification was also studied. Fig. 6.5 shows measured reaction rates of the char for steam gasification at a char conversion $(\mathrm{X})$ of 0.3 . The steam gasification is always preceded by some devolatilization of the char. At low temperatures $\left(700^{\circ} \mathrm{C}\right)$ this effect is still significant but at higher temperature it is negligible compared to the steam gasification.

The gasification rate of char from pyrolysis oil can be well described with an Arrhenius type of temperature dependence, giving an activation energy $\left(E_{a}\right)$ of $274 \mathrm{~kJ} \cdot \mathrm{mol}^{-1}$. This value is at the higher end as compared to earlier measured activation energies $\left(E_{\mathrm{a}}: 105-271 \mathrm{~kJ} \cdot \mathrm{mol}^{-1}\right)$ [18] for steam gasification of biomass originating chars.

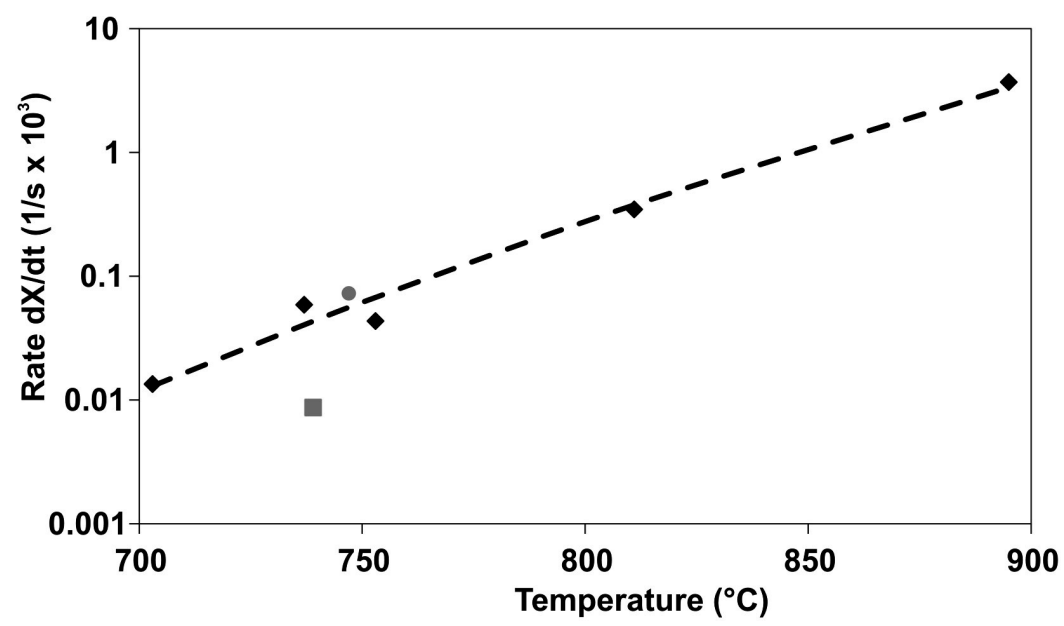

Fig. 6.5. Steam gasification rate as a function of temperature (including devolatilization) of char produced from evaporation of pyrolysis oil at $525^{\circ} \mathrm{C}$ at a conversion of $\mathrm{X}=0.3$. The dash line is the Arrhenius kinetic fit. The steam gasification rates of wood pyrolysis char and activated carbon are added for comparison. ( $₫$ ) Activated carbon; (•) Wood pyrolysis char; $(\diamond)$ Pyrolysis oil char produced at $525^{\circ} \mathrm{C}$. 
The steam gasification reactivity profiles for pyrolysis oil char, wood pyrolysis char and activated carbon at similar temperatures show distinct behavior (Fig. 6.6). The activated carbon shows a constant activity over the whole conversion range measured which can be interpreted as zero order gasification reactivity in char. In contrast, the rate of gasification for pyrolysis oil char and wood pyrolysis char decreases with increasing conversion, in line with the observations reported by Barrio et al. [18]. The following explanations can be given for this change in reactivity, i.e. (i) there is inhibition (for instance hydrogen and carbon monoxide), (ii) the carbon structure changes/is less accessible, resulting in an apparent different reaction order and (iii) the char ages in time, leading to less reactive chars. Since the amounts of hydrogen and carbon monoxide which are produced are negligible, (i) can be ruled out. (ii) and (iii) are both potentially feasible and therefore are expected to be dominant in explaining the decrease in rate with increasing conversion. The carbon surface structure has been shown on SEM photos to be very complex (Fig. 6.3). It could be assumed that big empty spheres react as a flat plate whereas smaller deposits react away as small porous spheres. This complex structure could lead to a higher initial rate decreasing with increasing conversion. The char has shown 'aging' behavior when it is subjected to elevated temperatures for a certain time (Fig. 6.4b and [19]), leading to a decreasing reactivity rate. The constant reactivity over time showed by the activated carbon can be explained by the fact that the overall structure does not change (in the conversion range measured) and does not undergo 'aging' since it was already subjected to higher temperatures during production.

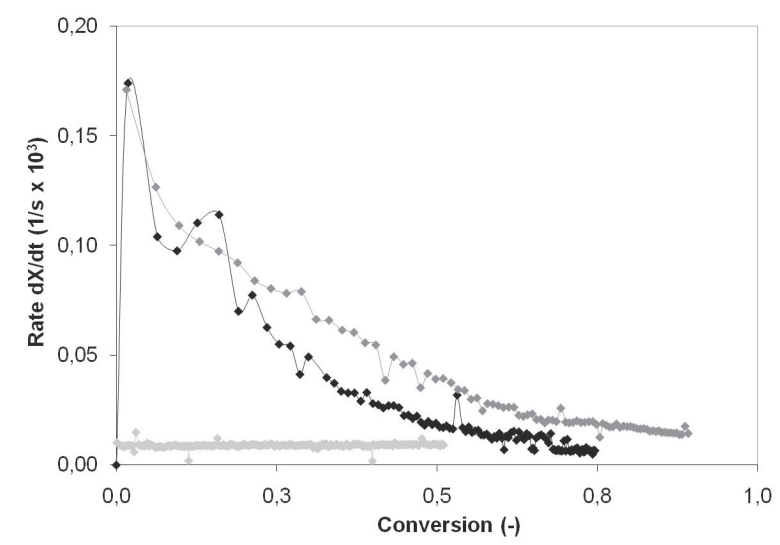

Fig. 6.6. Steam gasification rate profiles $\left(\mathrm{r}_{\mathrm{wt}}\right)$ of pyrolysis oil char $\left(\mathrm{T} \sim 753^{\circ} \mathrm{C}\right.$, $\left.\mathbf{a}\right)$, wood pyrolysis char $\left(\mathrm{T} \sim 747^{\circ} \mathrm{C}, \square\right)$ and activated carbon $\left(\mathrm{T} \sim 739^{\circ} \mathrm{C}, \square\right)$ at similar temperatures. 


\subsection{Implications for steam reforming of pyrolysis oil}

The presented results show that with the evaporation of pyrolysis oil char will always be formed. This has a large impact on the steam reforming process of pyrolysis oil whether single or staged reactor concepts are envisaged. Droplet evaporation in a heated empty space leaves a very light/fluffy char residue which easily elutriates from the reactor before it can be converted. It is therefore necessary to bind the char to a carrier. Sand [3] has shown to not have enough binding capacity (fluidization scrapes char of its surface) and therefore more porous materials in which char formation takes place, are preferred. How to contact the pyrolysis oil to such a carrier is not yet straightforward and has to be investigated further. The initial high temperature difference between the droplet and the carrier can limit the effectiveness of contacting. It is known that large pyrolysis oil droplets can bounce off a hot surface. Similar behavior is expected to occur over the hot carrier particles in the fluidized bed. Thus, the ideal oil/carrier particle diameter ratio will be key to avoid this effect: a high ratio will cool down the carrier, allowing the carrier to soak the oil and a low ratio will instantly heat the oil. Another option could be to modify the shape of the steam/dry reforming catalyst in such a way that residual char which elutriates from the fluidized bed is bound to it in the fixed-bed reactor where steam reforming takes place. In this way the char could get sufficient residence time to react. Preliminary tests in a bubbling fluidized with a more porous bed material have shown higher carbon to gas conversions as compared to 'inert' sand [20].

The char itself has combustion and gasification characteristics comparable to other biomass originated chars. When pyrolysis oil steam/dry reforming is considered, the char can be combusted to supply heat for the endothermic reforming reactions and evaporation. However, direct internal gasification of the char is preferred from an efficiency and process operation point of view [7]. Current steam gasification tests have shown that at the preferred temperature regime $\left(<700{ }^{\circ} \mathrm{C}\right)$ for operating a fluidized bed for evaporation, the rate of char conversion is too low. Higher operating pressures will probably enhance this conversion rate but catalytic active materials seem to be necessary to change char gasification conversion times from hours to minutes. 


\subsection{Conclusions}

Pyrolysis oil evaporation is always coupled with the formation of char which is formed via polymerization reactions. Char from pyrolysis oil evaporation has a very open structure and it consists of large hollow spheres onto which smaller particles are being deposited. The reactivity of char formed during pyrolysis oil evaporation towards combustion and steam gasification is comparable to that of char formed during pyrolysis of biomass. Reactivity is influenced significantly by char composition and by the temperature at which char has been formed. Char shows aging behavior when subjected to higher temperatures $\left(\geq 650-700{ }^{\circ} \mathrm{C}\right)$. The rate of char conversion for steam gasification is too low at the preferred temperature regime $\left(<700^{\circ} \mathrm{C}\right)$ for operating a fluidized bed for evaporation. 


\section{References}

[1] F. De Miguel Mercader, A. Ardiyanti, A. Gutierrez, S. Khromova, E. Leijenhorst, S.R.A. Kersten, J.A. Hogendoorn, W. Prins, M.J. Groeneveld, Proceedings of the 16th European Biomass Conference and Exhibition, Spain (2008) pp. 2103-2106.

[2] A. Corma, G.W. Huber, L. Sauvanaud, P. O'Conner, Journal of Catalysis 247 (2007) 307-327.

[3] G. Van Rossum, S.R.A. Kersten. W.P.M. Van Swaaij, Industrial Engineering Chemistry Research 46 (2007) 3959-3967.

[4] S. Czernik, R. French, C. Feik, E. Chornet, Industrial Engineering Chemistry Research 41 (2002) 4209-4215.

[5] P.N. Kechagiopoulos, S.S. Voutetakis, A.A. Lemonidou, I.A. Vasalos, Industrial Engineering Chemistry Research 48 (2009) 1400-1408.

[6] J.A. Medrano, M. Oliva, J. Ruiz, L. Garcia, J. Arauzo, Proceedings of the 16th European Biomass Conference and Exhibition, Spain (2008) pp. 2158-2162.

[7] G. Van Rossum, S.R.A. Kersten, W.P.M. Van Swaaij, Industrial Enginering Chemistry Research 48 (2009) 5857-5866.

[8] G. Van Rossum, B. Potic, S.R.A. Kersten, W.P.M. Van Swaaij, Catalysis Today 145 (2008) 10-18.

[9] A. Oasmaa, K. Sipilä, Y. Solantausta, E. Kuoppala, Energy \& Fuels 19 (2005) 2556-2561.

[10] B. Scholze, D. Meier, Journal of Analytical and Applied Pyrolysis 60 (2001) 41-54.

[11] B. Scholze, C. Hanse, D. Meier, Journal of Analytical and Applied Pyrolysis 58-59 (2001) 387-400.

[12] C. Branca, C. Di Blasi, Industrial Engineering Chemistry Research 45 (2006) 5891-5899.

[13] M.J. Wornat, B.G. Porter, N.Y.C Yang, Energy \& Fuels 8 (1994) 1131-1142.

[14] W.L.H. Hallett, N.A. Clark, Fuel 85 (2006) 532-544.

[15] M. García Pérez, P. Lappas, P. Hughes, L. Dell, A. Chaala, D. Kretschmer, C. Roy, IFRF Combustion Journal (2006) 200601.

[16] D. Knežević, W.P.M. Van Swaaij, S.R.A. Kersten, Industrial Engineering Chemistry Research 48 (2009) 4731-4743.

[17] C. Branca, C. Di Blasi, R. Elefante, Industrial Engineering Chemistry Research 44 (2005) 799-810.

[18] M. Barrio, B. Gøbel, H. Risnes, U. Henriksen, J.E. Hustad, L.H. Sørensen. Steam gasification of wood char and the effect of hydrogen inhibition on the 
chemical kinetics. Progress in thermochemical biomass conversion: Volume 1; Bridgwater, A.V., MPG Books Ltd: Cornwall, U.K., 2001; p 32-46.

[19] G. Chen, Q. Yu, K. Sjőstrőm, Journal of Analytical and Applied Pyrolysis 40-41 (1997) 491-499.

[20] M.F. Bleeker, H.J. Veringa, S.R.A. Kersten, Industrial Engineering Chemistry Research (submitted). 


\section{Chapter 7}

\section{Challenges in the production of sustainable fuels from pyrolysis oil - Design of efficient catalysts for gasification of char}

The catalytic performance of a ceria-zirconia-based catalyst for (i) steam $/ \mathrm{CO}_{2}$ gasification and (ii) combustion of char produced during pyrolysis oil evaporation was investigated and compared with the non-catalytic scenario in the temperature range 600-800 ${ }^{\circ} \mathrm{C}$. Kinetic studies revealed that the presence of the ceria-zirconia catalyst enhances char gasification rates significantly, up to one order of magnitude at $800{ }^{\circ} \mathrm{C}$, for both steam and $\mathrm{CO}_{2}$ gasification. It is suggested that the red-ox properties of the ceria-zirconia catalyst play a significant role in char gasification, by allowing oxygen mobility and activation of $\mathrm{H}_{2} \mathrm{O}$ and $\mathrm{CO}_{2}$. Furthermore, XPS and SEM characterization studies showed that the catalyst also influences the nature of char formed during pyrolysis oil evaporation to a great extent, by forming oxygenated species which are expected to be more reactive. 



\subsection{Introduction}

Biomass has recently received considerable attention as a potential sustainable feedstock for hydrogen production, as it would strongly contribute to the minimization of green house emissions. In the context of biomass, flash pyrolysis of lignocelluloses results in liquid pyrolysis oil. This makes it a convenient feedstock for storage, transport and processing as compared to the bulk biomass [1]. Catalytic steam reforming of pyrolysis oil is a promising option for hydrogen production. This reaction is carried out at high temperatures $\left(>800{ }^{\circ} \mathrm{C}\right)[2]$. Therefore, pyrolysis oil needs to be vaporized and heated to the desired reaction temperature. The high instability of pyrolysis oil at these high temperatures due to polymerization reactions results in carbonaceous solid residues, besides gases and vapors. These solid residues are referred to as homogeneous char. We have earlier shown and concluded [3] that formation of these carbonaceous deposits during pyrolysis oil evaporation cannot be avoided completely. These carbonaceous species can be detrimental to catalyst activity/stability and affect the efficiency of the overall reforming process [4].

Decoupling of (i) pyrolysis oil evaporation and (ii) reforming of the generated gases/vapors using a two-staged reactor concept (fluidized bed for vaporization + fixed-bed for steam reforming) has been reported [5] to successfully improve steam reforming catalyst stability and improve the process. Contact between char and reforming catalyst can be avoided if char is retained and converted in the fluidized bed itself and a catalyst is essential for this [4]. Steam and $\mathrm{CO}_{2}$ gasification are promising routes to enhance char removal during pyrolysis oil evaporation [4], producing at the same time a high value gas product (syngas). Pyrolysis oil is being evaporated at around $700{ }^{\circ} \mathrm{C}$ and at these low temperatures a catalyst is essential to achieve the required char gasification.

The envisioned down-stream processes determine the preference for steam or $\mathrm{CO}_{2}$ as gasification agent. Steam gasification is used to produce a hydrogen-rich gas product. On the contrary, combined steam and $\mathrm{CO}_{2}$ gasification is applied when the end application requires adjustment of the $\mathrm{H}_{2} / \mathrm{CO}$ ratio to lower values (2-3), e.g. for methanol synthesis and Fischer-Tropsch process. 
In the case that $\mathrm{CO}_{2}$ and/or steam gasification of char are insufficient for the required levels of char removal, an external partial combustion step, e.g. via a circulating fluidized bed, is required. The heat released during this exothermic combustion can be integrated to (i) pyrolysis oil evaporation or (ii) the endothermic reforming step. The circulation of char (solid) at high pressures (10-30 bar) is the main challenge, as it results in difficult process operability.

There are parallels to be drawn between char and coal gasification, as the challenges are very similar. Exhaustive work on coal gasification [6, 7] has shown that alkali metal compounds are effective catalysts for steam gasification of coal. Alkali metals are suggested to enhance gasification activity by assisting in the formation of $\mathrm{OH}$ groups [8, 9]. In the well known Exxon Catalytic Coal Gasification (CCG) process, for instance, $\mathrm{K}_{2} \mathrm{CO}_{3}$ was used as catalyst. This allowed reaction temperatures as low as $650-750{ }^{\circ} \mathrm{C}$. Similarly, enhanced gasification activity by alkali/alkaline earth-based catalysts has been reported also for $\mathrm{CO}_{2}$ gasification of coal $[7,10,11]$. In comparison to steam gasification, $\mathrm{CO}_{2}$ gasification is carried out at higher temperatures even in the presence of a catalyst $\left(750-900{ }^{\circ} \mathrm{C}\right)$.

The most widely reported coal gasification catalyst, $\mathrm{K}_{2} \mathrm{CO}_{3}$, however, presents quite a few problems. First of all, catalyst losses occur during gasification due to the formation of volatile $\mathrm{KOH}$ species. Secondly, interaction of catalyst with minerals present in coal leads to the formation of inactive and water insoluble compounds (e.g. potassium aluminum-silicates) from which recovery of the catalyst is difficult $[10,11]$. These catalyst losses make the gasification process uneconomic. Furthermore, it has been reported by Marshall and Smits [12] that potassium promotes the methanation reaction, which is favored at high pressure and low temperature (industrial desired conditions) and undesired in our case as part of the hydrogen would be consumed. Therefore, an alternative catalyst which has the ability to activate steam and $\mathrm{CO}_{2}$ and avoiding the above mentioned problems is desired for minimizing the problems related to homogeneous char formation during pyrolysis oil gasification. Tomisighe et al. [13] observed that $\mathrm{CeO}_{2}$ supported catalysts, e.g. $\mathrm{Rh} / \mathrm{CeO}_{2} / \mathrm{SiO}_{2}$, with the ability to activate both steam and $\mathrm{CO}_{2}[14,15]$, exhibited good activity in cellulose gasification. Ceria-based catalysts may thus be a good option for the steam and $\mathrm{CO}_{2}$ gasification of char formed during pyrolysis oil evaporation. 
The contact between catalyst and char is a crucial step in the gasification process, as it influences the catalytic activity to a large extent. In the case of coal gasification, a solution containing the catalyst precursor is sprayed on coal prior to gasification. In the case of pyrolysis oil, this approach cannot be applied since evaporation of pyrolysis oil is required previous to gasification. Instead, pyrolysis oil is sprayed on the catalyst particles in the gasification unit itself.

The aim of the present work is to develop an active and stable ceria catalyst for the (i) steam $/ \mathrm{CO}_{2}$ gasification and (ii) combustion of char formed during pyrolysis oil evaporation. Additionally, we aim at exploring and understanding whether the presence of catalyst has any influence on the nature of char formed during the pyrolysis oil evaporation, which would in turn influence the reactivity/kinetics of gasification.

\subsection{Experimental}

\subsubsection{Catalyst preparation}

Ceria catalysts were prepared using the wet impregnation technique. Yttrium stabilized zirconia (TOSOH, TZ-8Y) was first calcined at $850{ }^{\circ} \mathrm{C}$ (heating rate $\left.5{ }^{\circ} \mathrm{C} \cdot \mathrm{min}^{-1}\right)$ in flowing air $\left(30 \mathrm{ml} \cdot \mathrm{min}^{-1}\right)$ for $15 \mathrm{~h}$. The powder was then impregnated with an aqueous solution of $\mathrm{Ce}\left(\mathrm{NO}_{3}\right)_{3} \cdot 6 \mathrm{H}_{2} \mathrm{O}$ (Fuka) to yield a catalyst with $8.2 \%$ ceria loading. The $\mathrm{Ce}\left(\mathrm{NO}_{3}\right)_{3} \cdot 6 \mathrm{H}_{2} \mathrm{O}$ solution was mixed for $2 \mathrm{~h}$ and then dried at $50{ }^{\circ} \mathrm{C}$ in vacuum for $4 \mathrm{~h}$ in a rotary evaporator. Subsequently, the impregnated catalyst was first calcined at $700{ }^{\circ} \mathrm{C}$ (heating rate $\left.5^{\circ} \mathrm{C} \cdot \mathrm{min}^{-1}\right)$ in flowing air $\left(30 \mathrm{ml} \cdot \mathrm{min}^{-1}\right)$ for $6 \mathrm{~h}$ and then crushed and sieved to give grains of 0.3-0.6 mm. This catalyst will be, hereafter, denoted as Ce-Zr-O.

\subsubsection{Materials}

The pyrolysis oil was produced in the Process Development Unit of VTT (Finland) from forest residue [16].

For non-catalytic experiments, finely powdered char, produced at $525{ }^{\circ} \mathrm{C}$, was used. Char production is described in detail by van Rossum et al. in one of our earlier publications [3]. This char will be, hereafter, denoted as external char. 


\subsubsection{Contact between char and catalyst}

The contact between char and catalyst will depend on the type of catalyst and the contacting efficiency in a fluidized bed. In order to verify the relevance of such contact, two extreme situations have been tested in this work: (i) absorption of the oil into the catalyst particles and subsequent heating to produce char in-situ in the pores of the catalyst, resulting in optimal contact and (ii) physical mixing of char, produced externally, with the catalyst particles in a mortar, leading to poor (inter-particle) contact.

The preparation procedure for (i) was the following: approximately $40 \mathrm{mg}$ of Ce-Zr-O or $\mathrm{SiO}_{2}$ as an inert, reference material [17],(Aerosil 380, Degussa) was impregnated with pyrolysis oil (15-20 mg) in a small crucible. Subsequently, the impregnated catalyst was first heated up to $800{ }^{\circ} \mathrm{C}\left(10^{\circ} \mathrm{C} \cdot \mathrm{min}^{-1}\right)$ in flowing argon $\left(60 \mathrm{ml} \cdot \mathrm{min}^{-1}\right)$ and then cooled down to room temperature under the same atmosphere. This char will be, hereafter, referred as internal char.

For (ii), finely powdered char (denoted as external char) was physically mixed manually in a mortar with known amounts of catalyst. This char will be, hereafter, denoted as physical mix char.

\subsubsection{Catalyst and char characterizations}

Catalyst composition was determined with X-ray fluorescence spectroscopy (XRF) (Phillips PW 1480 spectrometer). Char composition was determined with an elemental analyzer (Fisions Instruments 1108 EA CHN-S).

BET specific surface area and porosity were measured with nitrogen adsorption-desorption at $77 \mathrm{~K}$ in a Micromeritics TriStar instrument. The samples were first degassed at $300{ }^{\circ} \mathrm{C}$ in nitrogen.

X-Ray photoelectron spectra (XPS) were recorded on a Physical Electronics Quantera XPS system using a monochromatic Al Ka (1486.6 eV) X-ray source operated at 24W (beam diameter $100 \mu \mathrm{m}$ with charge neutralization. Survey scans were collected from $-5 \mathrm{eV}$ to $1345 \mathrm{eV}$ with a pass energy equal to $224 \mathrm{eV}$ and $0.8 \mathrm{eV}$ step size. All scans were taken at a $45^{\circ}$ tilt angle. The pressure inside the chamber 
remained $<2 \cdot 10^{-9}$ torr. Peak shape fitting was performed with Gaussian-Lorentzian sum function and Shirley background [18] subtraction with constraints applied to full width, half maximum (FWHM) values. All binding energies were referenced against a main $\mathrm{C}(1 \mathrm{~s})$ peak at $285.0 \mathrm{eV}$.

Scanning Electron Microscope (SEM) images were obtained using a LEO 1550 instrument.

\subsubsection{Reactivity measurements}

$\mathrm{CO}_{2}$ gasification experiments were performed in a Mettler Toledo thermo-gravimetric analyzer (TGA) equipped with good temperature control $\left( \pm 0.7^{\circ} \mathrm{C}\right)$ and a balance $(1 \mu \mathrm{g}$ sensitivity). Experiments were performed isothermally in the temperature range $600-900{ }^{\circ} \mathrm{C}$ in a small crucible. Samples were heated rapidly $\left(\sim 150{ }^{\circ} \mathrm{C} \cdot \mathrm{min}^{-1}\right)$ to the desired temperature in a mixture of carbon dioxide $\left(20 \mathrm{ml} \cdot \mathrm{min}^{-1}\right)$ and argon $\left(40 \mathrm{ml} \cdot \mathrm{min}^{-1}\right)$. All experiments were carried out until char conversion was completed or reached steady values. Additional to the TGA balance, the samples weight loss was quantified with a very accurate external balance $(0.01 \mu \mathrm{g}$ sensitivity).

Combustion experiments were performed in the same system. The samples were heated to $800{ }^{\circ} \mathrm{C}$ at $5{ }^{\circ} \mathrm{C} \cdot \mathrm{min}^{-1}$ in a mixture of air $\left(20 \mathrm{ml} \cdot \mathrm{min}^{-1}\right)$ and argon $\left(40 \mathrm{ml} \cdot \mathrm{min}^{-1}\right)$. The initial and final weights of samples were also quantified with the same external balance. It is noteworthy to mention that isothermal experiments were not done for combustion experiments as reaction would have occurred to a too large extent during heating up.

Steam gasification experiments were carried out in a fixed-bed reactor. A quartz tube (Ø $45 \mathrm{~mm}$, length $400 \mathrm{~mm}$ ) was used which was placed inside an electrically heated oven. A steam generator was used to create a constant steam flow $\left(300{ }^{\circ} \mathrm{C}\right.$, 0.15-0.5 $\mathrm{g} \cdot \mathrm{min}^{-1}$ ) and preheated nitrogen (ca. $200{ }^{\circ} \mathrm{C}, 9 \mathrm{ml} \cdot \mathrm{min}^{-1}$ ) was added as internal standard. The amount of steam added compared to the char sample (ca. 4-10 mg) was high enough that zero conversion of steam could be assumed. Samples were placed at the end of the oven to ensure adequate preheating of the steam/nitrogen and isothermal gasification. The samples containing char only were pre-mixed with 
quartz (ca. $150 \mathrm{mg}$ ) to minimize the pressure drop which was created due to the fine structure of the char. However some pressure drop (0.2-0.5 bar) over the sample was observed. For the samples containing char and catalyst $(9 \mathrm{mg}$ of char $+55 \mathrm{mg}$ $\mathrm{Ce}-\mathrm{Zr}-\mathrm{O})$ no quartz was used. The maximum pressure drop observed in this case was 0.3 bar. The reactor outlet was cooled to $\sim 15^{\circ} \mathrm{C}$ and the steam was condensed out completely. A micro-GC (Varian CP-4900) was used to analyze the gas composition.

\subsubsection{Definitions and reaction equations}

The degree of conversion, $X(t)$, is obtained in this study from the following expression, $X=\left(m_{0}-m_{t}\right) / m_{0} ;[-]$, where $m_{t}$ is the char mass at a certain time $t$ and $m_{0}$ represents the char mass at the beginning of the gasification. The rate of gasification is here defined as the change of conversion over a time period, $r_{w t}=d X / d t ;\left[\mathrm{s}^{-1}\right]$. The rate of combustion is here defined as the change of conversion over a temperature range $r_{w T}=d X / d T ;\left[{ }^{\circ} \mathrm{C}^{-1}\right]$.

The reaction equations involved in char gasification and combustion are listed in Eqs. 7.1-7.4:

$$
\begin{array}{ll}
\mathrm{C}_{x} \mathrm{H}_{y} \mathrm{O}_{z(s)}+(x-z) \mathrm{H}_{2} \mathrm{O} \rightarrow x \mathrm{CO}+\left(\frac{y}{2}+x-z\right) \mathrm{H}_{2} & \text { (Steam gasification) } \\
\mathrm{C}_{x} \mathrm{H}_{y} \mathrm{O}_{z(s)}+(x-z) \mathrm{CO}_{2} \rightarrow(2 x-z) \mathrm{CO}+\left(\frac{y}{2}\right) \mathrm{H}_{2} & \left(\mathrm{CO}_{2}\right. \text { gasification) } \\
\mathrm{C}_{x} \mathrm{H}_{y} \mathrm{O}_{z(s)}+\left(\frac{y}{4}+x-\frac{z}{2}\right) \mathrm{O}_{2} \rightarrow x \mathrm{CO}_{2}+\frac{y}{2} \mathrm{H}_{2} \mathrm{O} & \text { (Combustion) } \\
\mathrm{CO}+\mathrm{H}_{2} \mathrm{O} \leftrightarrow \mathrm{CO}_{2}+\mathrm{H}_{2} &
\end{array}
$$

\subsection{Results}

\subsubsection{Catalysts characterization}

The ceria content in the catalyst was $8.2 \mathrm{wt} . \%$, in the range intended for preparation. Specific surface areas for $\mathrm{Ce}-\mathrm{Zr}-\mathrm{O}$ and $\mathrm{SiO}_{2}$ powders after calcination at $700{ }^{\circ} \mathrm{C}$ were $18 \mathrm{~m}^{2} \cdot \mathrm{g}^{-1}$ and $351 \mathrm{~m}^{2} \cdot \mathrm{g}^{-1}$, respectively. The nitrogen sorption isotherm 
and the pore volume distribution (inset) for the Ce-Zr-O catalyst are shown in Fig. 7.1. The isotherm, assigned to types $I I \& I V$ [19], is typical for particles which either are non-porous or possess macropores and relatively low external surface areas. Fig. 7.1 (inset) also shows that $\mathrm{Ce}-\mathrm{Zr}-\mathrm{O}$ presented a broad pore distribution, with a mean pore diameter $\sim 50 \mathrm{~nm}$.

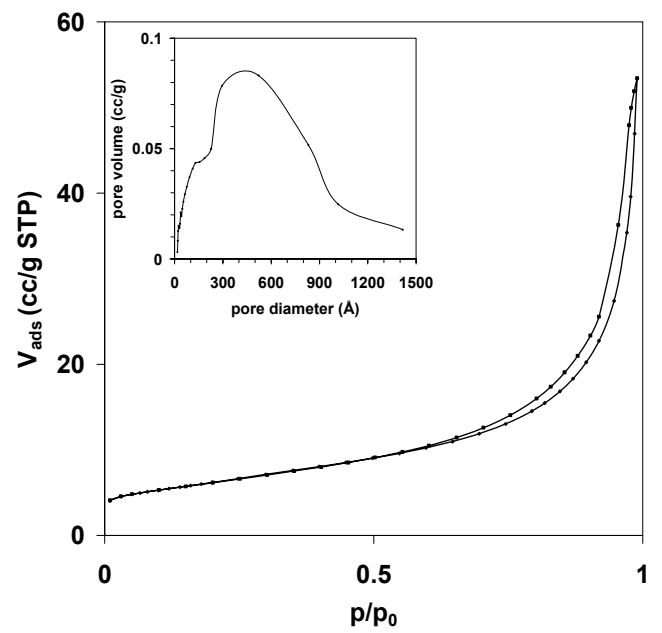

Fig. 7.1. Nitrogen adsorption isotherm and pore volume distribution (inset) of Ce-Zr-O after calcination at $700{ }^{\circ} \mathrm{C}$.

\subsubsection{Composition of pyrolysis oil and external char}

The carbon and hydrogen content in the pyrolysis oil were $40.6 \mathrm{wt} . \%$ and $7.6 \mathrm{wt} . \%$ respectively. The rest (51.8 wt.\%) was mainly oxygen and small amounts of other components, e.g., sulfur, nitrogen and ash. Char produced externally consisted of 76.7 wt.\% carbon, 3.4 wt.\% hydrogen and 19.9 wt.\% oxygen.

\subsubsection{Characterization of internal char deposited on Ce-Zr-O}

Fig. 7.2 illustrates char formed during pyrolysis oil evaporation in the presence of Ce-Zr-O. A typical SEM photograph of the cross-section of a catalyst particle with internal char is shown in Fig. 7.2a. A zoomed-in image of the cross-section (Fig. 7.2b) reveals that char formed during pyrolysis oil evaporation is evenly distributed in the catalyst (dark spots are carbon), filling the catalyst pores. An energy dispersive X-ray spectroscopy (EDX) analysis of this section (Fig. 7.2c) confirms the presence of 
carbon and thus, char. Fig. 7.3a shows a typical tilted top-view SEM image of internal char deposited on a catalyst particle. EDX analysis (Fig. 7.3c) clearly indicates that these deposits were mainly composed of char. As clearly seen, char was not exclusively located in the catalyst pores. A small amount of char formed an external thin surface layer. As shown in Fig. 7.3b (cross-section), this external deposits layer was only few $\mu \mathrm{m}$ thick (up to $5 \mu \mathrm{m}$ ). Considering that catalyst particles size is in the range $300-600 \mu \mathrm{m}$, the volume of the external deposits layer is equivalent to a very small fraction of the volume of a catalyst particle $(\sim 2.5 \%)$.
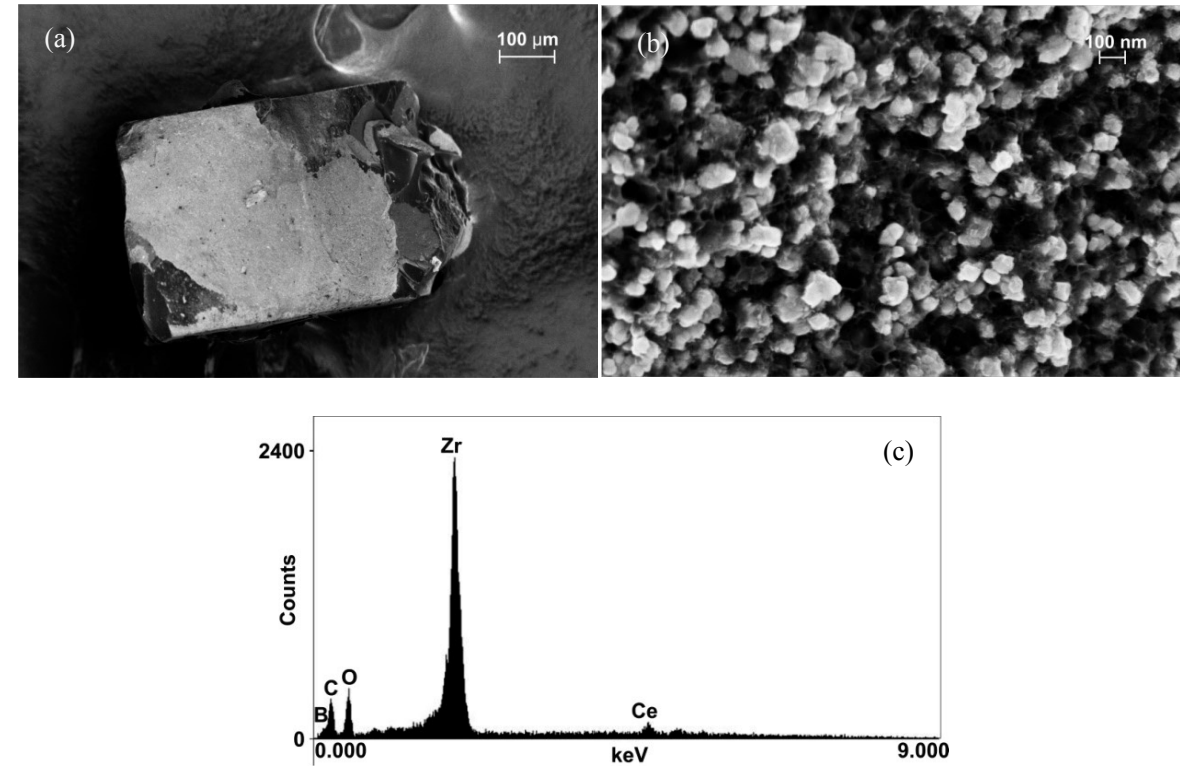

Fig. 7.2. Cross-sectional SEM images on a cutled catalyst particle of internal char deposited on $\mathrm{Ce}-\mathrm{Zr}-\mathrm{O}$, (a) Low magnification and (b) high magnification. The light area is the cross section. EDX analysis of a selected area (c).

Presence of internal char in $\mathrm{Ce}-\mathrm{Zr}-\mathrm{O}$ resulted in an increase in specific surface area $\left(86 \mathrm{~m}^{2} \cdot \mathrm{g}^{-1}\right)$ as compared to that determined in the absence of char $\left(18 \mathrm{~m}^{2} \cdot \mathrm{g}^{-1}\right)$. Nitrogen adsorption and pore volume distribution for internal char deposited on $\mathrm{Ce}-\mathrm{Zr}-\mathrm{O}$ are shown in Fig. 7.4. The physisorption isotherm, Type $\mathrm{IV}$, is characteristic for materials possessing mesoporosity. The corresponding hysteresis loop was associated with narrow slit-like pores, Type H4. Decrease in macropore volume (compare Fig. insets 7.1 and 7.4 (top)) when Ce-Zr-O was impregnated with internal char indicates that the char was located in the catalyst pores, influencing the textural 
properties of $\mathrm{Ce}-\mathrm{Zr}-\mathrm{O}$, in line with the SEM results. An oxidation treatment of this sample resulted in a macropore volume comparable to that of the fresh $\mathrm{Ce}-\mathrm{Zr}-\mathrm{O}$, confirming the location of char in the Ce-Zr-O pores (Fig. inset 7.4 (bottom)).
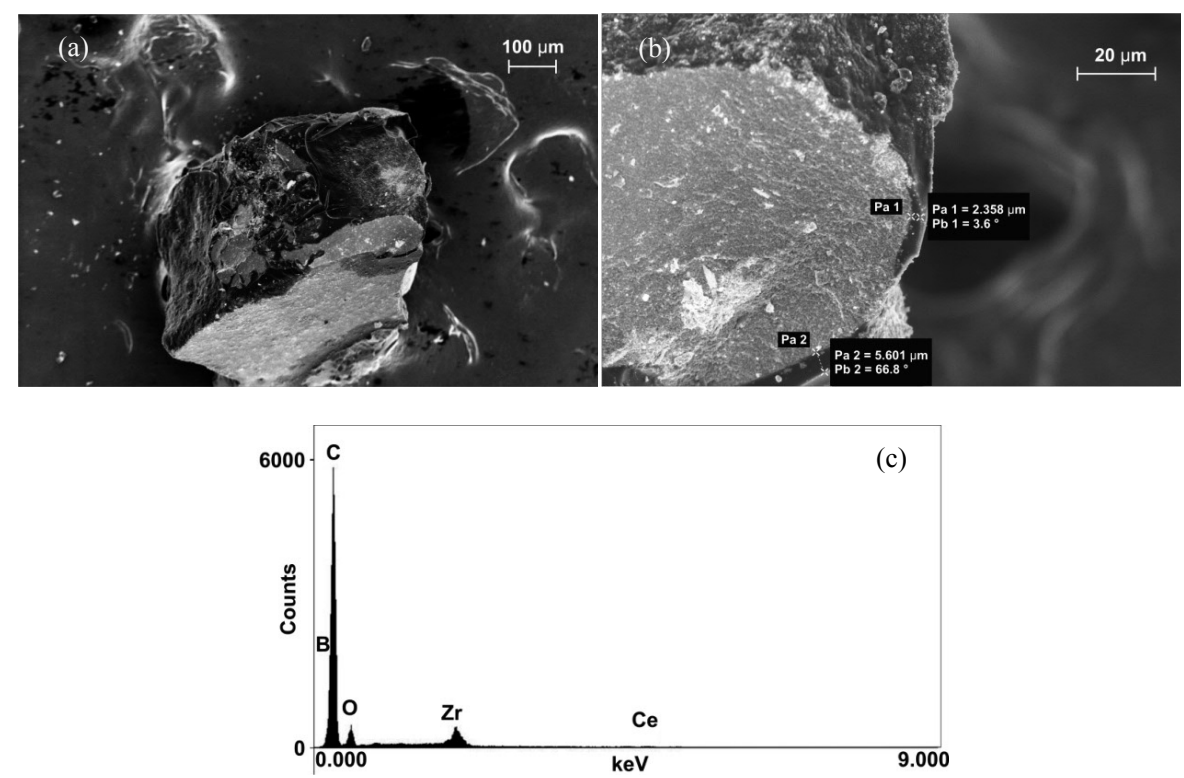

Fig. 7.3. Tow-view SEM images of internal char deposited on Ce-Zr-O, (a) Low magnification and (b) high magnification. EDX analysis of a selected area (c).

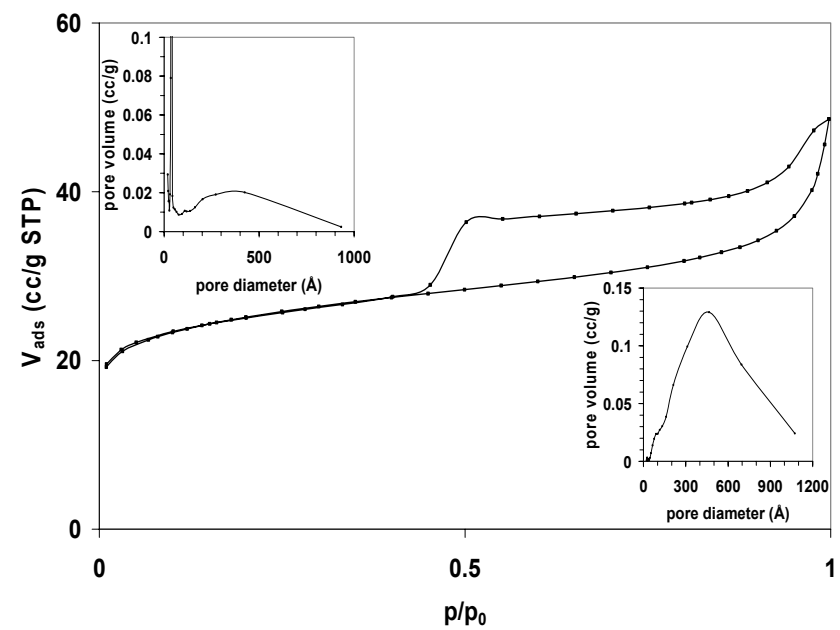

Fig. 7.4. Nitrogen adsorption isotherm of char deposited on Ce-Zr-O and pore volume distribution of this sample before (top inset) and after (bottom inset) an oxidation treatment. 
Fig. 7.5 presents the XPS spectra of external char, Ce-Zr-O and internal char deposited on $\mathrm{Ce}-\mathrm{Zr}-\mathrm{O}$ in the regions of the binding energy of the $\mathrm{C} 1 \mathrm{~s}$ and $\mathrm{O} 1 \mathrm{~s}$. Figs. 7.5a and 7.5b correspond to $\mathrm{C} 1 \mathrm{~s}$ spectra of internal char deposited on Ce-Zr-O and external char in the absence of Ce-Zr-O, respectively. Both spectra present a main peak at $285 \mathrm{eV}$, attributed to C-C and C-H bonds [20-22] in hydrocarbons, and a long tail at higher binding energies which is composed of 4 overlapping individual peaks associated to $\mathrm{O}-\mathrm{C}$ type bond $\left(\mathrm{C}-\mathrm{O}, \mathrm{C}=\mathrm{O}, \mathrm{O}-\mathrm{C}=\mathrm{O}\right.$ and $\mathrm{CO}_{3}$ ) [20-22]. Comparison between the $\mathrm{C} 1 \mathrm{~s}$ spectra of both samples (Fig. 5c) clearly shows that $\mathrm{O}-\mathrm{C}$ type bond $(>286 \mathrm{eV})$ is more dominant in internal char (formed in the presence of the Ce- $\mathrm{Zr}-\mathrm{O}$ catalyst).

Spectra in the region of the binding energy of the O1s electrons are depicted in Figs. $7.5 \mathrm{~d}$-g. The spectrum corresponding to Ce-Zr-O (Fig. 7.5d) presents a peak which can be described as contribution from two different types of oxygen. One type of oxygen is assigned to a main peak centered at $531.2 \mathrm{eV}$ and the second one is associated to a minor peak centered at $532.2 \mathrm{eV}$. The $\mathrm{O} 1 \mathrm{~s}$ fitting of the spectrum corresponding to external char is shown in Fig. 7.5e. In this case, the optimal fitting of the curve is constituted of 4 peaks, at positions $531.6 \mathrm{eV}, 533.6 \mathrm{eV}, 536.4 \mathrm{eV}$ and $539.0 \mathrm{eV}$. The first two peaks are assigned to $\mathrm{C}=\mathrm{O}$ and $\mathrm{C}-\mathrm{O}$ bonds, respectively, and the other two at higher binding energies are satellite peaks [20-22]. Fig. 7.5f shows the O1s fitting spectrum of internal char deposited on Ce-Zr-O. A broad peak in the range 528-538 eV was observed. The best fitting for this peak was obtained with the addition of 4 individual bands at the following binding energies: $529.9 \mathrm{eV}, 531.5 \mathrm{eV}$, $532.6 \mathrm{eV}$ and $534.17 \mathrm{eV}$. Fig. 7.5g shows the overlapping of the $\mathrm{O} 1 \mathrm{~s}$ spectrum of internal char deposited on Ce-Zr-O (light solid line) with the individual curves and the resulting fitting of the O1s spectra corresponding to Ce-Zr-O (dash lines) and external char (dark solid lines). To do so, the parameters associated with the main band for both $\mathrm{Ce}-\mathrm{Zr}-\mathrm{O}$ and external char, namely peak position, area and full width half maximum (FWHM), were constrained when comparing them with the O1s spectrum of internal char deposited on the catalyst. The parameters associated with the rest of the individual bands depended on those associated with the main band (see Tables 7.1 and 7.2). It is clear from Fig. 7.5g that the fitting (dash/dot line) resulting from the sum up of the 6 individual bands ( 2 from $\mathrm{Ce}-\mathrm{Zr}-\mathrm{O}$ and 4 from external char) is not 

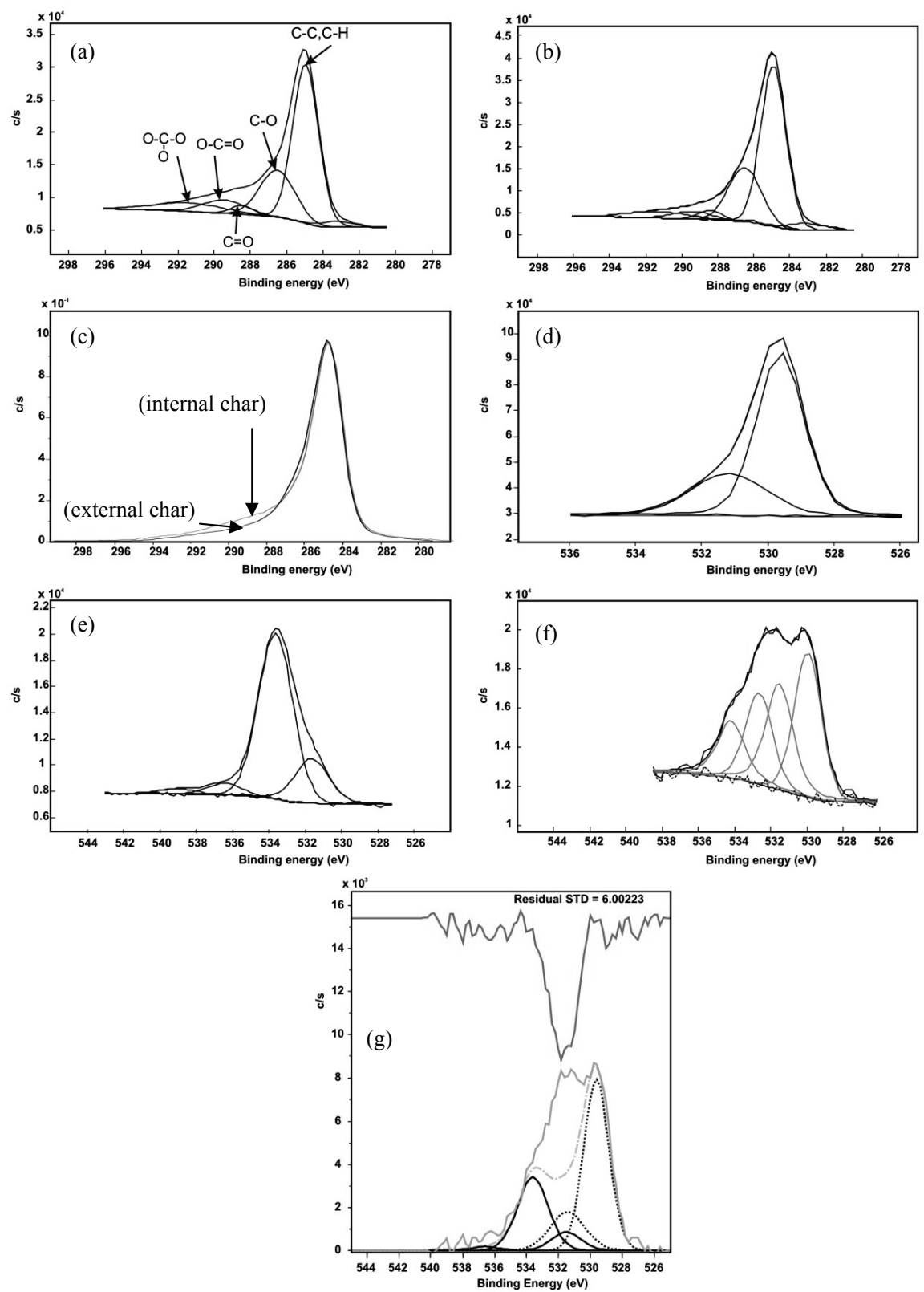

Fig. 7.5. XPS spectra of (a) $\mathrm{C} 1 \mathrm{~s}$ internal char deposited on Ce-Zr-O, (b) $\mathrm{C} 1 \mathrm{~s}$ external char, (c) comparison $\mathrm{C} 1 \mathrm{~s}$ external char (dark line)/internal char deposited on Ce-Zr-O (light line), (d) O1s $\mathrm{Ce}-\mathrm{Zr}-\mathrm{O}$, (e) O1s external char, (f) O1s internal char deposited on Ce-Zr-O (g) comparison O1s $\mathrm{Ce}-\mathrm{Zr}-\mathrm{O}$ (dash lines)/external char (dark solid lines)/internal char deposited on Ce-Zr-O (light solid line)/fitting (dash-dot line). 
equivalent to the O1s spectrum associated with internal char deposited on Ce-Zr-O. There is remaining intensity which could not be explained by any of the individual components. This remaining peak, so called residual, shown on the top of the figure, is in the binding energy range $530.2-533.5 \mathrm{eV}$. This binding energy range is typical of O-C bonds $\left(\mathrm{CO}_{3}[20]\right)$, in good agreement with the findings obtained for $\mathrm{C} 1 \mathrm{~s}$ (Fig. 7.5a).

Table 7.1. Quantification parameters of the O1s spectrum of char

\begin{tabular}{crrrcc}
\hline Band & Peak position & Area & FWHM & $\Delta$ peak position & Area \\
\hline 1 & 533.7 & 30516 & 2.23 & 0 & A \\
2 & 531.6 & 7714 & 2.23 & -2.1 & $\mathrm{~A}^{*} 0.252$ \\
3 & 536.7 & 1731 & 2.23 & +3.0 & $\mathrm{~A}^{*} 0.057$ \\
4 & 539.2 & 744 & 2.23 & +5.5 & $\mathrm{~A}^{*} 0.024$ \\
\hline
\end{tabular}

Table 7.2. Quantification parameters of the O1s spectrum of $\mathrm{Ce}-\mathrm{Zr}-\mathrm{O}$

\begin{tabular}{ccccccc}
\hline Band & Peak position & Area & FWHM & $\Delta$ peak position & Area & $\Delta$ FWHM \\
\hline 1 & 529.6 & 81655 & 1.80 & 0 & A & 0 \\
2 & 531.4 & 25969 & 2.54 & +1.8 & A*0.318 & +0.74 \\
\hline
\end{tabular}

\subsubsection{Characterization of internal char deposited on Ce-Zr-O}

\subsubsection{1 $\mathrm{CO}_{2}$ gasification}

Fig. 7.6 shows a typical result for $\mathrm{CO}_{2}$ (dry) gasification of char expressed as char conversion vs. reaction time at $700{ }^{\circ} \mathrm{C}$. Reaction rate can be calculated with the derivative. The resulting rates for internal char (deposited on $\mathrm{Ce}-\mathrm{Zr}-\mathrm{O}$ ) in the temperature range between 600 and $800{ }^{\circ} \mathrm{C}$ are shown in Fig. 7.7 as a function of the conversion. As can be clearly seen, char reactivity increased sharply with temperature. The initial rate of gasification at $800{ }^{\circ} \mathrm{C}$ was approximately one order of magnitude higher than that at $600{ }^{\circ} \mathrm{C}$. The influence of temperature in the reactivity profile is also observed in Fig. 7.7. At low temperatures $\left(600^{\circ} \mathrm{C}\right)$, char was gasified at a 
relatively constant rate throughout the whole experiment whereas the rate of gasification at higher temperatures $\left(700{ }^{\circ} \mathrm{C}\right.$ and $\left.800^{\circ} \mathrm{C}\right)$ decreased significantly with conversion.

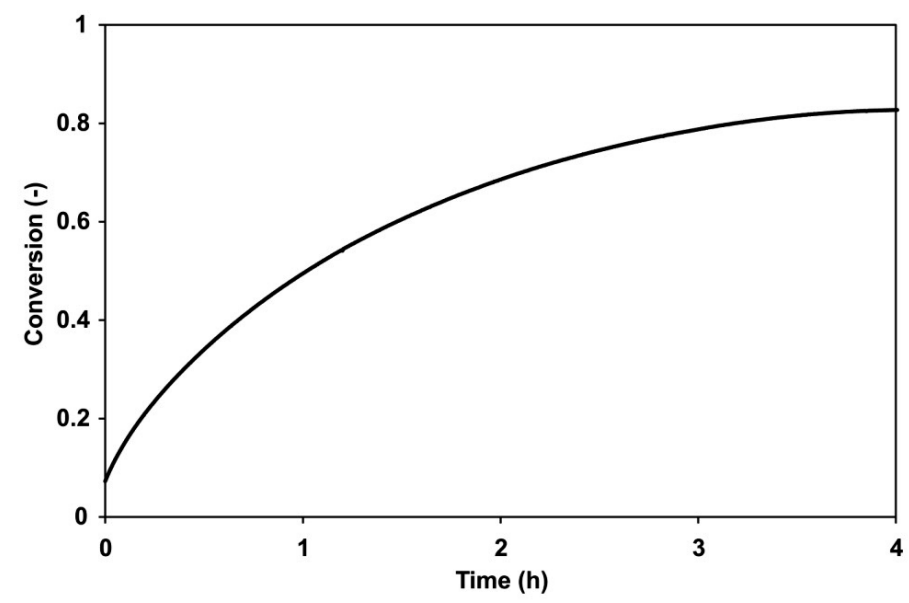

Fig. 7.6. Char conversion as a function of the reaction time for $\mathrm{CO}_{2}$ gasification of internal char deposited on Ce-Zr-O at $700{ }^{\circ} \mathrm{C} . \mathrm{CO}_{2}$ flow: $20 \mathrm{ml} \cdot \mathrm{min}^{-1}$; Ar flow: $40 \mathrm{ml} \cdot \mathrm{min}^{-1}$.

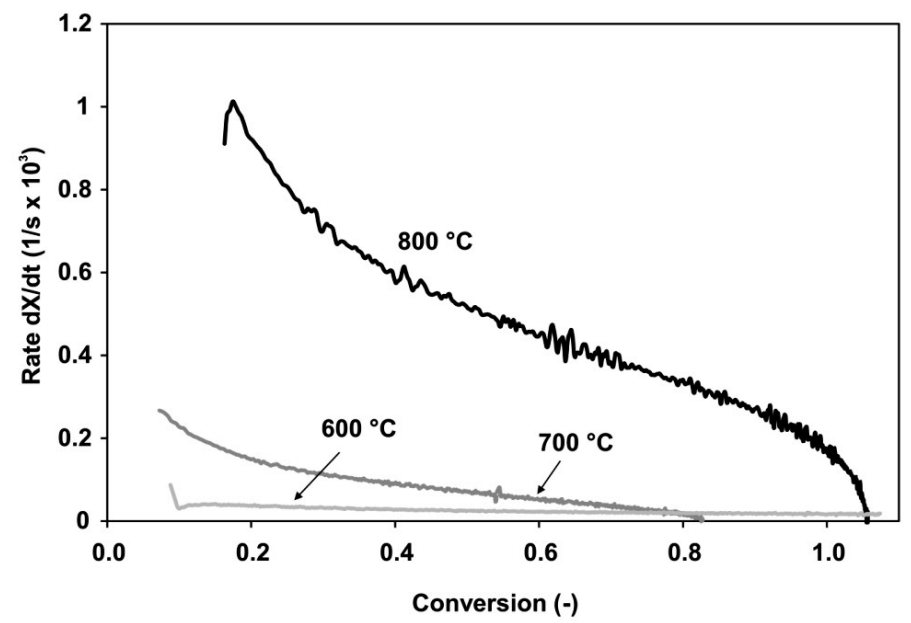

Fig. 7.7. Reactivity of internal char in the presence of catalyst as a function of the degree of conversion during $\mathrm{CO}_{2}$ gasification. $\mathrm{CO}_{2}$ flow: $20 \mathrm{ml} \cdot \mathrm{min}^{-1}$; Ar flow: $40 \mathrm{ml} \cdot \mathrm{min}^{-1} . \mathrm{T}=600{ }^{\circ} \mathrm{C}(-)$; $\mathrm{T}=700{ }^{\circ} \mathrm{C}(-) ; \mathrm{T}=800^{\circ} \mathrm{C}(-)$.

Comparison of char reactivity at $30 \%$ conversion in the presence (internal char) and absence (external char) of $\mathrm{Ce}-\mathrm{Zr}-\mathrm{O}$ is illustrated in Fig. 7.8. As expected, the 
presence of $\mathrm{Ce}-\mathrm{Zr}-\mathrm{O}$ had a significant influence on the rate of gasification, especially at the higher temperatures, e.g., the presence of $\mathrm{Ce}-\mathrm{Zr}-\mathrm{O}$ allowed char to gasify one order of magnitude faster than char gasified non-catalytically.

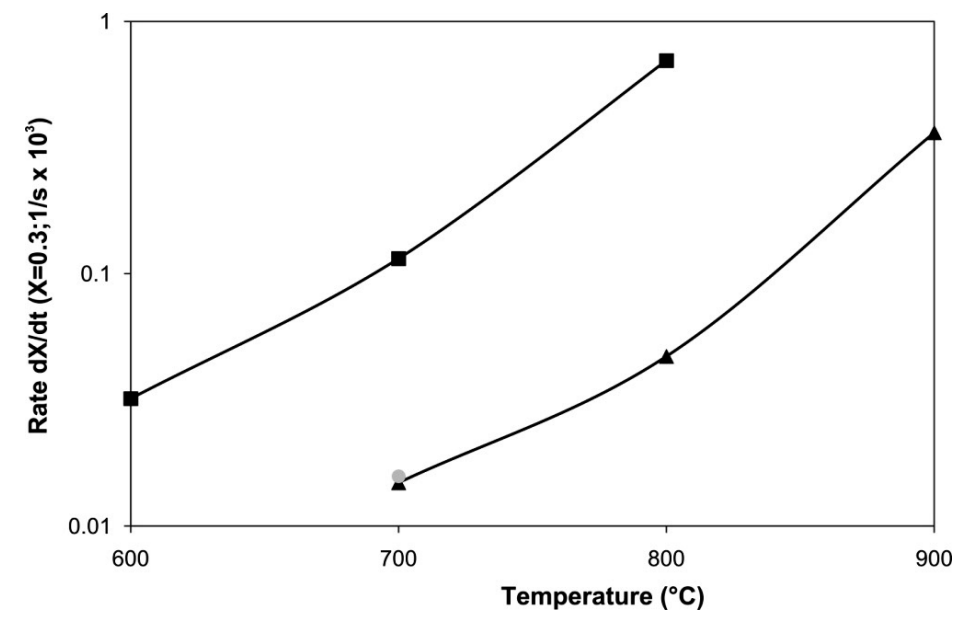

Fig. 7.8. Char reactivity during $\mathrm{CO}_{2}$ gasification at $30 \%$ conversion as a function of temperature in the absence (external char) and presence (internal char) of catalyst. ( $\mathbf{\Delta})$ external char, ( $\mathbf{(})$ internal char deposited on $\mathrm{Ce}-\mathrm{Zr}-\mathrm{O}$ and $(\odot)$ internal char deposited on $\mathrm{SiO}_{2} \cdot \mathrm{CO}_{2}$ flow: $20 \mathrm{ml} \cdot \mathrm{min}^{-1}$; Ar flow: $40 \mathrm{ml} \cdot \mathrm{min}^{-1}$.

Fig. 7.8 also shows the reactivity at $30 \%$ conversion of internal char deposited on $\mathrm{SiO}_{2}$ at $700{ }^{\circ} \mathrm{C}$. The reactivity in this case was comparable to that observed non-catalytically, indicating the inertness of $\mathrm{SiO}_{2}$ and the inability to enhance.

Table 7.3. Activation energies calculated by The Arrhenius equation for the catalytic and non-catalytic steam and $\mathrm{CO}_{2}$ gasification of char.

\begin{tabular}{lcc}
\cline { 2 - 3 } & \multicolumn{2}{c}{$\mathrm{E}_{\mathrm{a}}\left(\mathrm{kJ} \cdot \mathrm{mol}^{-1}\right)$} \\
\cline { 2 - 3 } & $\mathrm{H}_{2} \mathrm{O}$ & $\mathrm{CO}_{2}$ \\
\hline Catalytic & 157 & 119 \\
Non-catalytic & 274 & 160 \\
\hline
\end{tabular}

Table 7.3 compares the activation energies calculated according the Arrhenius equation for the catalytic (internal char deposited on $\mathrm{Ce}-\mathrm{Zr}-\mathrm{O}$ ) and the non-catalytic 
(external char) $\mathrm{CO}_{2}$ gasification. As expected, the presence of $\mathrm{Ce}-\mathrm{Zr}-\mathrm{O}$ clearly lowered the activation energy and thus increased the reaction rate.

\subsubsection{Steam gasification}

Reactivity profiles for the steam gasification of internal char deposited on $\mathrm{Ce}-\mathrm{Zr}-\mathrm{O}$ as a function of the degree of conversion and temperature are shown in Fig. 7.9. Similar to dry $\left(\mathrm{CO}_{2}\right)$ gasification, both reactivity profile and rate of gasification were found to strongly depend on temperature. Char gasification at $580{ }^{\circ} \mathrm{C}$ was very slow and constant. The increase in temperature up to $625{ }^{\circ} \mathrm{C}$ increased the rate of gasification by a factor of 4 and resulted in a comparable reactivity profile. Char reactivity was further increased when carrying out experiments at $735{ }^{\circ} \mathrm{C}$. Reactivity at this reaction temperature was approximately 40 times faster than that obtained at $580{ }^{\circ} \mathrm{C}$. In contrast to the observations at lower temperatures, reactivity at $735^{\circ} \mathrm{C}$ decreased as char was being consumed.

Char reactivity for steam gasification in the presence (internal char) and absence (external char) of Ce-Zr-O is compared at $30 \%$ conversion in Fig. 7.10. Similar to our findings for $\mathrm{CO}_{2}$ gasification, char reactivity during steam gasification was enhanced by the presence of $\mathrm{Ce}-\mathrm{Zr}-\mathrm{O}$, however to a lower extent. Comparison between reaction times at approximately $735{ }^{\circ} \mathrm{C}$ indicates that char gasification occurred $\sim 3.5$ times faster when the reaction was carried out catalytically.

Regarding the gas product distribution, $\mathrm{H}_{2}, \mathrm{CO}$ and $\mathrm{CO}_{2}$ were the only products formed during gasification of the internal char deposited on $\mathrm{Ce}-\mathrm{Zr}-\mathrm{O}$. In the non-catalytic case (external char), besides the above mentioned products, small amounts of $\mathrm{CH}_{4}$ were also observed in the beginning of the reaction. The $\mathrm{CO} / \mathrm{CO}_{2}$ ratio during catalytic internal char gasification was approximately 0.06 whereas $\mathrm{CO}$ and $\mathrm{CO}_{2}$ concentrations were comparable in the non-catalytic case, indicating that in the presence of $\mathrm{Ce}-\mathrm{Zr}-\mathrm{O}$ the water-gas shift equilibrium was completely shifted towards $\mathrm{CO}_{2}$ and $\mathrm{H}_{2}$ production.

Fig. 7.10 also includes the reactivity of char physically mixed with $\mathrm{Ce}-\mathrm{Zr}-\mathrm{O}$ (solid-solid contact) at $740{ }^{\circ} \mathrm{C}$. It is obvious from the figure that the reactivity of this char was remarkably slower ( $\sim 3$ times) than that observed for internal char deposited 


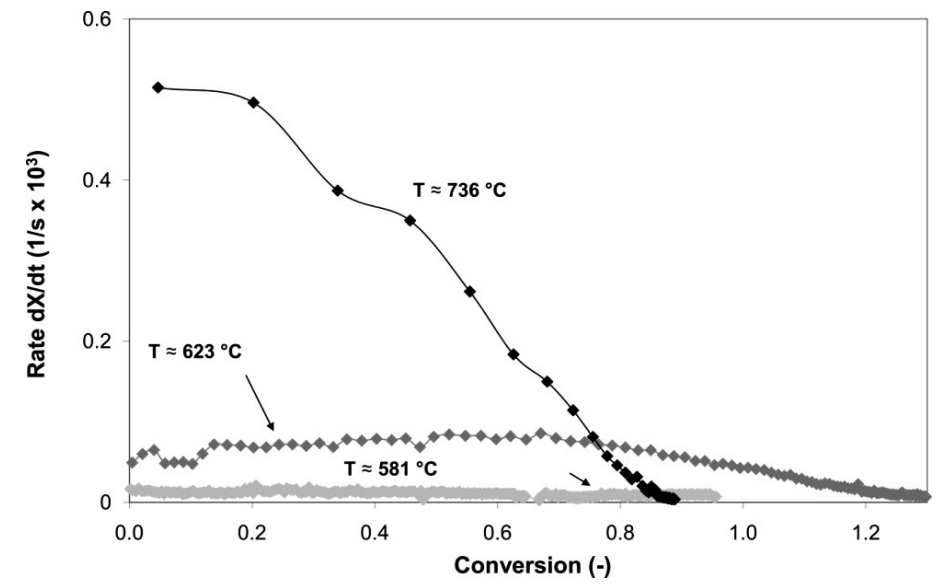

Fig. 7.9. Reactivity of internal char in the presence of catalyst as a function of the degree of conversion during steam gasification. Steam flow: $0.15-0.5 \mathrm{~g} \cdot \mathrm{min}^{-1}, \mathrm{~N}_{2}$ flow: $9 \mathrm{ml} \cdot \mathrm{min}^{-1} \cdot \mathrm{T} \approx 581{ }^{\circ} \mathrm{C}(\diamond)$, $\Delta \mathrm{p} \approx 0.2$ bar $; \mathrm{T} \approx 623{ }^{\circ} \mathrm{C}, \Delta \mathrm{p} \approx 0.2 \operatorname{bar}(\diamond) ; \mathrm{T} \approx 736^{\circ} \mathrm{C}, \Delta \mathrm{p} \approx 0.3 \operatorname{bar}(\bullet)$.

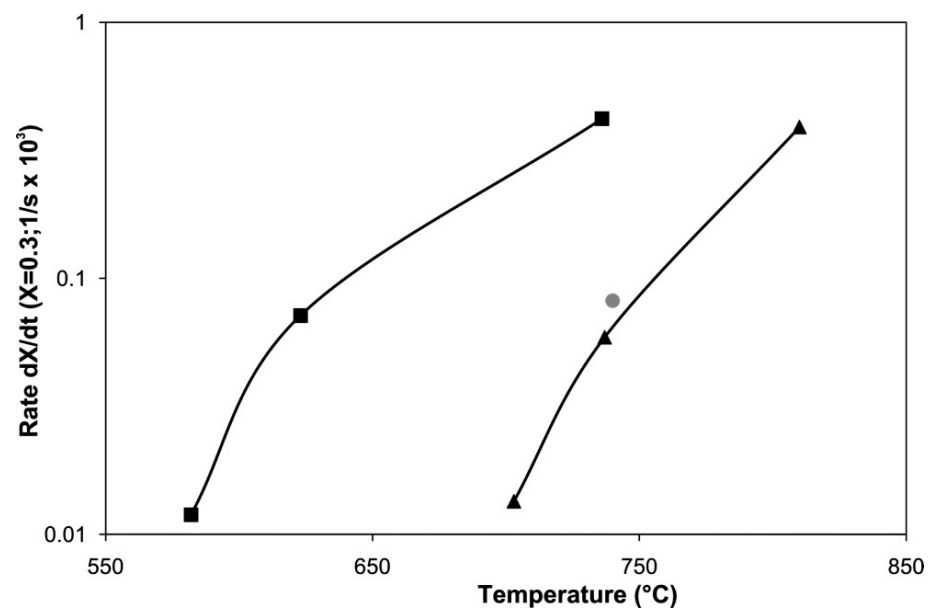

Fig. 7.10. Char reactivity during steam gasification at $30 \%$ conversion as a function of temperature in the absence (external char) and presence (internal and physical mixing char) of catalyst. ( $\mathbf{\Delta}$ ) external char, (-) internal char deposited on Ce-Zr-O and ( $)$ physical mix char with Ce-Zr-O. Steam flow: 0.15-0.5 g. $\mathrm{min}^{-1} ; \mathrm{N}_{2}$ flow: $9 \mathrm{ml} \cdot \mathrm{min}^{-1}$.

on $\mathrm{Ce}-\mathrm{Zr}-\mathrm{O}$ and comparable to that associated with external char (gasified non-catalytically) under similar reaction conditions. These results clearly indicate that physical mixing of char with catalyst particles results in poor contact and thus, char gasification is only enhanced marginally by the presence of the Ce-Zr-O catalyst. 
Table 7.3 shows, similarly to the observations on $\mathrm{CO}_{2}$ gasification, that the presence of Ce-Zr-O (internal char) decreases the activation energy significantly, thus increasing the rate of steam gasification.

\subsubsection{Combustion}

Fig. 7.11 shows the reactivity profiles for char combustion in the presence (internal char) and absence (external char) of $\mathrm{Ce}-\mathrm{Zr}-\mathrm{O}$ as a function of temperature. Char combusted non-catalytically resulted in a main peak centered around $460{ }^{\circ} \mathrm{C}$ and a smaller, second peak with maximum at $530{ }^{\circ} \mathrm{C}$. The presence of $\mathrm{Ce}-\mathrm{Zr}-\mathrm{O}$ enhanced char combustion drastically, as evidenced by the presence of a single peak centered at $330^{\circ} \mathrm{C}$.

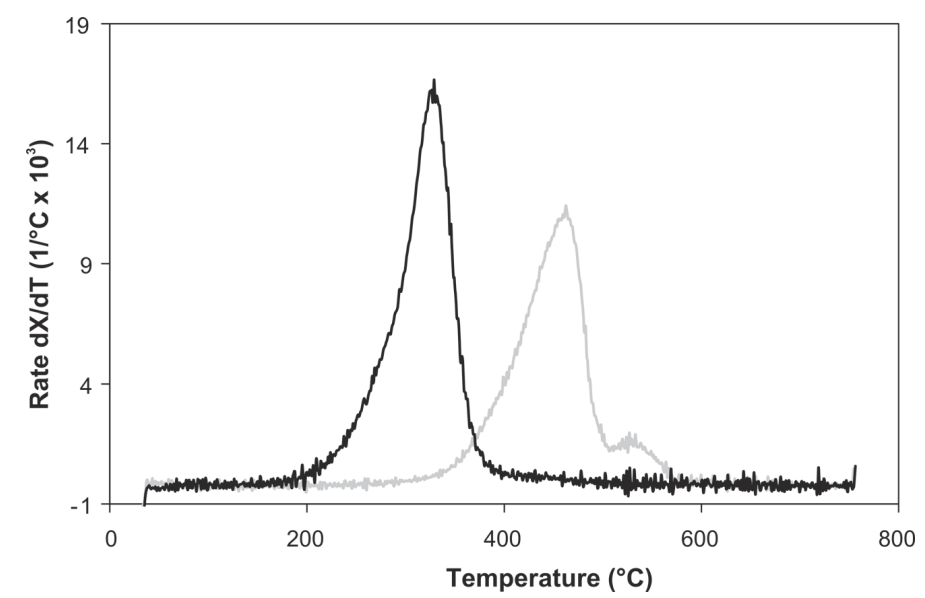

Fig. 7.11. Char reactivity during combustion as a function of temperature in the absence (external char, - ) and presence (internal char, - ) of Ce-Zr-O. Air flow: $20 \mathrm{ml} \cdot \mathrm{min}^{-1}$; Ar flow: $40 \mathrm{ml} \cdot \mathrm{min}^{-1}$; heating rate: $5^{\circ} \mathrm{C} \cdot \mathrm{min}^{-1}$.

\subsection{Discussion}

This work reports on catalytic steam gasification of pyrolysis oil derived char and it adds on our previous non-catalytic findings. Additionally, this work addresses catalytic $\mathrm{CO}_{2}$ gasification and char combustion as alternative approaches to convert char formed during pyrolysis oil evaporation. The kinetic results convincingly show the effectiveness of the ceria-zirconia catalyst to convert char to syngas via catalytic 
steam and $\mathrm{CO}_{2}$ gasification at relatively low temperatures $\left(<700{ }^{\circ} \mathrm{C}\right)$, as evidenced by the substantial enhancement in char reactivity and the decrease in activation energies, as compared to the non-catalytic scenario (see Figs. 7.8 and 7.10).

In addition, this catalyst shows excellent combustion activity. In the presence of $\mathrm{Ce}-\mathrm{Zr}-\mathrm{O}$, internal char is fully combusted at temperatures below $400{ }^{\circ} \mathrm{C}$ whereas non-catalytic combustion of (external) char requires temperatures up to $\sim 570{ }^{\circ} \mathrm{C}$. This enhanced reactivity by using ceria-based catalyst is in good agreement with results of McKee [23] on combustion of graphite, reporting that addition of cerium to the graphite allowed initial combustion of graphite at $450{ }^{\circ} \mathrm{C}$, instead of $700{ }^{\circ} \mathrm{C}$ in absence of catalyst.

It is here appropriate to recall that external char, produced in the absence of catalyst, was formed at $525^{\circ} \mathrm{C}$. On the other hand, internal char, formed in-situ on the catalyst, was produced by heating the catalyst impregnated with oil up to $750{ }^{\circ} \mathrm{C}$. Thus, the char produced catalytically was formed at higher temperatures. We have recently reported that reactivity of char strongly depends on the temperature at which it is formed [3]. The higher the temperature the more devolatilization (gas release) char undergoes, resulting in a lower reactivity of char. Accordingly, the char produced in the presence of catalyst should be less reactive than char produced non-catalytically. Therefore, the already excellent catalytic effect of the ceria-zirconia catalyst on gasification and combustion rates is even more significant and as a consequence, the temperature required for char conversion could be lowered even further, especially since pyrolysis oil evaporation can be carried out at lower temperatures, e.g. $500^{\circ} \mathrm{C}$.

It is well known that $\mathrm{CeO}_{2}$ has excellent oxygen exchange capacity involving red-ox changes between $\mathrm{Ce}^{4+}$ and $\mathrm{Ce}^{3+}[24]$ and that it has ability to activate steam and $\mathrm{CO}_{2}$. Sharma et al. [14] clearly proved that re-oxidation of $\mathrm{CeO}_{2-\mathrm{x}}$ by $\mathrm{CO}_{2}$ occurs at temperatures as low as $350{ }^{\circ} \mathrm{C}$. Further, water activation $\left(\mathrm{CeO}_{2-\mathrm{x}}\right.$ re-oxidation) over ceria was reported to proceed rapidly at $550{ }^{\circ} \mathrm{C}$ [25]. Therefore both reactants, $\mathrm{CO}_{2}$ and steam, are activated on $\mathrm{Ce}-\mathrm{Zr}-\mathrm{O}$ at the reaction temperatures used in this study. Interestingly, our kinetic results reveal that non-catalytic steam gasification of char is significantly faster (up to one order of magnitude at $800{ }^{\circ} \mathrm{C}$ ) than $\mathrm{CO}_{2}$ gasification 
(compare Figs. 7.8 and 7.10). In contrast, under comparable reaction conditions and in the presence of $\mathrm{Ce}-\mathrm{Zr}-\mathrm{O}$, the rate for steam gasification is only slightly higher than that observed for $\mathrm{CO}_{2}$ gasification. These facts indicate that the $\mathrm{Ce}-\mathrm{Zr}-\mathrm{O}$ red-ox catalyst is able to speed up gasification with $\mathrm{CO}_{2}$ even more effectively than with water.

Differences in the $\mathrm{CO} / \mathrm{CO}_{2}$ ratio and $\mathrm{H}_{2}$ amounts between catalytic and non-catalytic gasification of char confirms that $\mathrm{Ce}-\mathrm{Zr}-\mathrm{O}$ can readily activate both steam and $\mathrm{CO}_{2}$. In the case of catalytic steam gasification (internal char deposited on $\mathrm{Ce}-\mathrm{Zr}-\mathrm{O})$, the $\mathrm{CO} / \mathrm{CO}_{2}$ ratio is much lower than that observed non-catalytically (external char) (0.06 vs. 1), indicating that in the presence of $\mathrm{Ce}-\mathrm{Zr}-\mathrm{O}$ the water-gas shift equilibrium is completely shifted towards $\mathrm{CO}_{2}$ and $\mathrm{H}_{2}$ production, in agreement with literature [26-28]. It is important to highlight that, in contrast to alkali-based and earth-alkali-based (K, Na, Mg, Ca) or nickel-based catalysts [29-31], used in catalytic coal gasification, ceria-zirconia catalysts do not catalyze the methanation reaction when mixed with carbon $[12,30,32,33]$ and thus hydrogen yields remain high.

Characterization results suggest that $\mathrm{Ce}-\mathrm{Zr}-\mathrm{O}$ also plays a crucial role in the nature of char formed during pyrolysis oil evaporation (internal char) and this could also explain the differences in char reactivity between catalytic and non-catalytic conditions. It was concluded from XPS spectra that char produced during pyrolysis oil evaporation in the presence of $\mathrm{Ce}-\mathrm{Zr}-\mathrm{O}$ is more oxygenated than that formed non-catalytically. Domazetis et al. [30] observed similar oxygenate species for the catalytic gasification of low-quality coals over Fe-based catalysts. The authors speculated that Fe-oxygenate complexes formed during pyrolysis participate in metal assisted pyrolysis and gasification. As mentioned earlier, it is well established that ceria possesses excellent red-ox properties [34, 35], generating oxygen vacancies and thus allowing release and storage of oxygen ("oxygen storage capacity" (OSC)) $[35,36]$. Therefore, we may speculate that occurrence of oxygen release from ceria during pyrolysis oil evaporation results in oxygen vacancies and formation of new carbon-oxygen bonds in char (e.g. carbonyl and carbonate groups). Steam and $\mathrm{CO}_{2}$ (potential oxidants) released in gas phase during evaporation would be able to fill in the generated oxygen vacancies in ceria. 
Evolution of these new C-O type of bonds suggests that the contact between (internal) char and Ce-Zr-O is excellent. This hypothesis was confirmed by SEM images (Fig. 7.2), which showed that char is located inside the pores of Ce- $\mathrm{Zr}-\mathrm{O}$ and thus in intimate contact with the catalyst. Change in porosity between fresh Ce-Zr-O and $\mathrm{Ce}-\mathrm{Zr}-\mathrm{O}$ mixed with internal char (compare Figs. 7.1 and 7.4) also suggested that char is mostly deposited in the macropores of Ce-Zr-O, in agreement with our previous findings. Further porosity measurements of a sample containing internal char deposited on $\mathrm{Ce}-\mathrm{Zr}-\mathrm{O}$ which had been previously submitted to an oxidation treatment $\left(\mathrm{O}_{2} / \mathrm{He}\right)$ (Fig. inset 7.4 (bottom)) corroborated the location of char by showing comparable porosity to that observed for the fresh Ce-Zr-O. A small amount of char, however, forms an external thin surface layer of few $\mu \mathrm{m}$ thick (see Fig. 7.3b). This suggests that a small fraction of the oil does not penetrate into the catalyst pores prior to char formation, resulting in over-impregnation of the catalyst particles. As a consequence, this small amount of char is not in intimate contact with the catalyst, resulting in a slightly lower rate of gasification. Therefore, higher reactivity of char could be obtained by optimizing (i) catalyst/pyrolysis ratios and (ii) contact between catalyst/char.

Up to this point, our findings clearly show the significant role of the $\mathrm{Ce}-\mathrm{Zr}-\mathrm{O}$ catalyst in enhancing char reactivity during steam and $\mathrm{CO}_{2}$ gasification; however, discrimination between the role of the catalyst during pyrolysis oil evaporation and that during char gasification requires further research.

In the case of coal gasification, it has been stated in literature that surface area plays an important role in the rate of gasification. The higher the surface area the faster the gasification rate is $[37,38]$. In order to study the influence of catalyst surface area in char gasification, $\mathrm{CO}_{2}$ gasification of internal char was carried out over a $\mathrm{SiO}_{2}$ catalyst with very high surface area $\left(351 \mathrm{~m}^{2} \cdot \mathrm{g}^{-1}\right)$ and with no ability to activate $\mathrm{CO}_{2}$. The low gasification rate obtained over this $\mathrm{SiO}_{2}$ catalyst (Fig. 7.8), comparable to that observed non-catalytically and much lower than that over Ce-Zr-O, confirmed the essential role of $\mathrm{Ce}-\mathrm{Zr}-\mathrm{O}$ in activating $\mathrm{CO}_{2}$ and steam and thus enhancing char gasification and ruled out any positive contribution of surface area of non-catalytic materials in the rate of char gasification. Based on our observations and discussions we thus propose that ceria provides oxygen for char gasification, resulting in oxygen 
vacancies, and that activation of $\mathrm{CO}_{2}$ and steam on $\mathrm{Ce}-\mathrm{Zr}-\mathrm{O}$ leads to regeneration of the oxygen vacancies. This is consistent with our studies of steam reforming of acetic acid [39] and water-gas shift [40], where the role of ceria is suggested and observed. Another important observation is that differences in char production which are expected to result in different char structures, yielded to comparable gasification rates, as observed for internal char deposited on $\mathrm{SiO}_{2}$ (char produced at low heating rate) and external char (char produced at high heating rate ([3])).

The excellent catalytic activity of Ce-Zr-O could also explain the dependence of reactivity profiles of internal char on temperature for both steam and $\mathrm{CO}_{2}$ gasification (Figs. 7.7 and 7.9). At low temperatures, the rate of gasification is relatively constant throughout the whole conversion range. In contrast, at high temperatures, the rate of gasification decreases significantly with the degree of conversion. Scheme 7.1 illustrates the proposed explanation for this behavior. Before reaction (top image) part of the char is in intimate contact with the Ce-Zr-O particles. Due to the high catalytic activity of Ce-Zr-O, the char in close contact with the catalyst particles will be the first to react away. As a result, the catalyst pores will start to retrieve their porosity and the remaining char will be submitted to forces due to tension which will induce break-up of the initial char structure, resulting in smaller char-catalyst interface. It has been shown that catalytic gasification is much faster than the analogous non-catalytic and therefore poorer contact between the char and the catalyst will result in a decrease in gasification rate with increasing conversion. As proposed in Scheme 7.1, char gasified at high temperatures (bottom left image) results in a more abrupt decrease in char-catalyst interface than char gently gasified at lower temperatures (bottom right image), resulting in a decrease in the rate of gasification with increasing the degree of conversion to a larger extent than at lower temperatures.

Based on the obtained results, Scheme 7.2 illustrates the possible paths involved in steam and $\mathrm{CO}_{2}$ char gasification in the presence and absence of Ce-Zr-O.

Char gasification occurs mainly via two parallel routes. On one hand, the initial char, which is slightly oxygenated, here referred as $C$, is first converted to more reactive intermediates (further oxygenated char), here denoted as $C-O$ (route $2 a)$, which react further to lead to the end products $\left(\mathrm{CO}_{\mathrm{x}}+\mathrm{H}_{2}\right)$ (route $\left.2 \mathrm{~b}\right)$. As discussed 


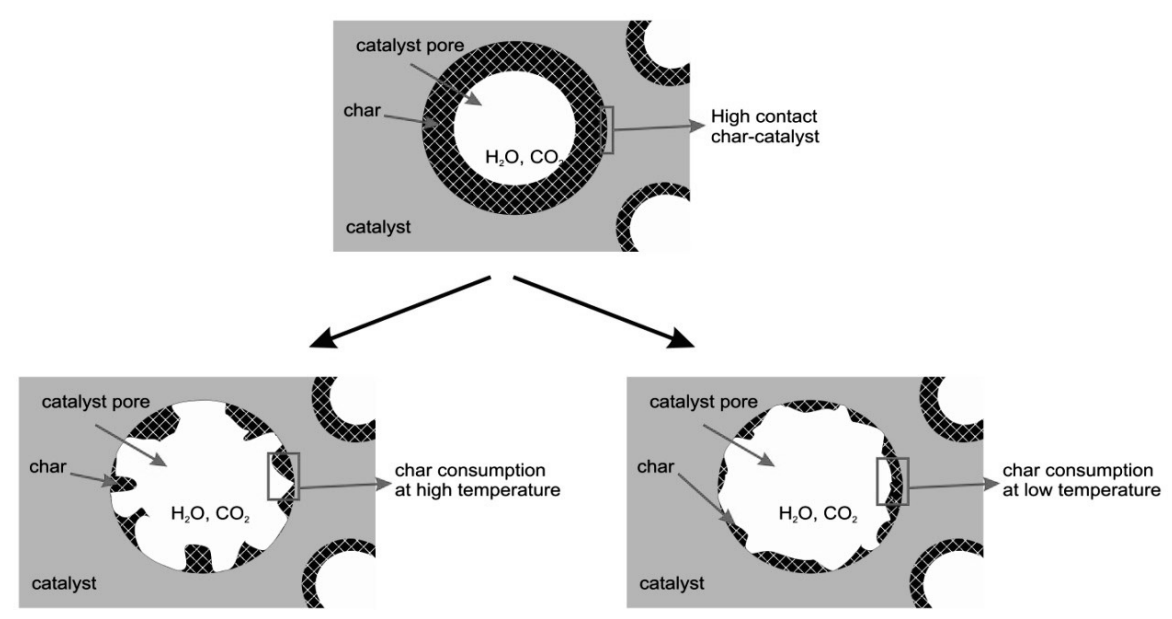

Scheme 7.1. Proposed explanation for the dependence of char reactivity profiles on temperature. Char deposited on porous $\mathrm{Ce}-\mathrm{Zr}$-O before reaction (top) and char consumption at high temperatures (bottom left) and low temperatures (bottom right).

earlier, pyrolysis oil evaporation in the presence of $\mathrm{Ce}-\mathrm{Zr}-\mathrm{O}$ results in the generation of more oxygenated char (C-O bond type species). Therefore, according to the proposed scheme, Ce-Zr-O facilitates the pre-steps involved in char gasification (routes 2a), explaining, to a certain extent, the enhancement in the reactivity of char.

In previous work on non-catalytic steam gasification [3], we concluded that, similar to coal gasification [41], part of the initial char undergoes a gradual transformation (aging process) towards a hydrogen and oxygen lean type of char, denoted as $\mathrm{C}^{*}$, which can be accompanied by volatilization (gases release). This results in a more stable and thus less reactive char (route 1). It was further concluded

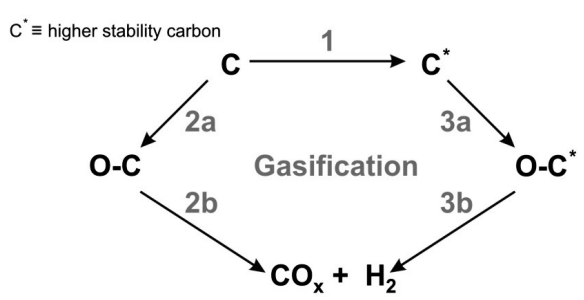

Scheme 7.2. Proposed mechanism for $\mathrm{CO}_{2}$ and steam gasification of char derived from pyrolysis oil. 
that volatilization is favored at high temperatures. In the present study, char on the catalyst was produced at $750{ }^{\circ} \mathrm{C}$. According to the non-catalytic results, at this temperature, volatilization should have already occurred to a large extent. Therefore, further volatilization during catalytic $\mathrm{CO}_{2}$ and steam gasification is expected to occur only marginally. Similar to the analogous route described for the initial char, the aged char, $\mathrm{C}^{*}$, is further converted to more reactive oxygenate intermediates, represented as $C^{*}-O$, (route $3 \mathrm{a}$ ) which are gasified to $\mathrm{CO}_{\mathrm{x}}+\mathrm{H}_{2}$ (route $3 \mathrm{~b}$ ). Also in this case, $\mathrm{Ce}-\mathrm{Zr}-\mathrm{O}$ is suggested to enhance the route towards formation of oxygenates, resulting in an enhancement in gasification rates.

To summarize, $\mathrm{Ce}-\mathrm{Zr}-\mathrm{O}$ enhances $\mathrm{CO}_{2}$ and steam gasification of char derived from pyrolysis oil significantly. Based on our observations and discussions addressed in this work, we conclude that this enhancement could be further improved. Two main aspects should be considered for optimization: the catalyst/char contact and the temperature in which char is produced on the catalyst.

\subsection{Conclusions}

Our findings convincingly demonstrate that pyrolysis oil evaporation in combination with internal catalytic char gasification is feasible at relatively low temperatures $\left(\leq 700{ }^{\circ} \mathrm{C}\right)$. This can be explained by the high efficiency of the ceria-zirconia-based catalyst to convert char to syngas via catalytic steam $/ \mathrm{CO}_{2}$ gasification at those low temperatures. The role of the $\mathrm{Ce}-\mathrm{Zr}-\mathrm{O}$ catalyst is suggested to provide oxygen for char gasification, resulting in oxygen vacancies, and activate steam and $\mathrm{CO}_{2}$ to regenerate the oxygen vacancies formed. Additionally, Ce-Zr-O facilitates the pre-steps involved in char gasification, by making char more oxygenated and thus more reactive during pyrolysis oil evaporation. It has been shown that a good contact between char and catalyst is essential for the catalytic enhancement in char gasification. The catalyst/pyrolysis oil ratio and the temperature in which char is produced are two aspects to be optimized. 


\section{References}

[1] C.A. Mullen, and A.A. Boateng, Energy \& Fuels 22 (2008) 2104-2109.

[2] C. Rioche, S. Kulkarni, F.C. Meunier, J.P. Breen, and R. Burch, Applied Catalysis B: Environmental 61 (2005) 130-139.

[3] G. van Rossum, B. Matas Güell, R.P.B. Ramachandran, K. Seshan, L. Lefferts, W.P.M. van Swaaij, and S.R.A. Kersten, AIChE (submitted).

[4] G. van Rossum, S.R.A. Kersten, and W.P.M. van Swaaij, Industrial \& Engineering Chemistry Research 48 (2009) 5857-5866.

[5] G. van Rossum, S.R.A. Kersten, and W.P.M. van Swaaij, Industrial \& Engineering Chemistry Research 46 (2007) 3959-3967.

[6] Y. Shang Jung, and E.E. Wolf, Fuel 62 (1983) 738-741.

[7] P.L. Walker Jr, S. Matsumoto, T. Hanzawa, T. Muira, and I.M.K. Ismail, Fuel 62 (1983) 140-149.

[8] M.A. Henderson, Surface Science Reports 46 (2002) 1-308.

[9] J.W. Snoeck, G.F. Froment, and M. Fowles, Industrial Engineering Chemistry Research 41 (2002) 3548-3556.

[10] G. Bruno, M. Buroni, L. Carvani, G.D. Piero, and G. Passoni, Fuel 67 (1988) 67-72.

[11] A. Sharma, H. Kawashima, I. Saito, and T. Takanohashi, Energy \& Fuels (In Press).

[12] H.A. Marshall, and F.C.R.M. Smits, Proceedings - 9th Annual International Conference on coal gasification, liquefaction and conversion to electricity (1982).

[13] K. Tomishige, M. Asadullah, and K. Kunimori, Catalysis Today 89 (2004) 389-403.

[14] S. Sharma, S. Hilaire, J.M. Vohs, R.J. Gorte, and H.W. Jen, Journal of Catalysis 190 (2000) 199-204.

[15] B. Matas Güell, I. Babich, K.P. Nichols, J.G.E. Gardeniers, L. Lefferts, and K. Seshan, Applied Catalysis B: Environmental 90 (2009) 38-44.

[16] A. Oasmaa, K. Sipila, Y. Solantausta, and E. Kuoppala, Energy \& Fuels 19 (2005) 2556-2561.

[17] Y. Schuurman, C. Marquez-Alvarez, V.C.H. Kroll, and C. Mirodatos, Catalysis Today 46 (1998) 185-192.

[18] M. Oku, S. Suzuki, N. Ohtsu, T. Shishido, and K. Wagatsuma, Applied Surface Science 254 (2008) 5141-5148.

[19] K.S.W. Sing, Pure Applied Chemistry 54 (1982) 2201-2218. 
[20] G. Beamson, and D. Briggs, High Resolution XPS of Organic Polymers: The Scienta ESCA300 Database. John Wiley \& Sons, Chichester, 1992.

[21] J.F. Moulder, W.F. Stickle, P.E. Sobol, and K.D. Bomben. 1992. Handbook of X-ray Photoelectron Spectroscopy, Perkin-Elmer Corporation, Eden Prairie.

[22] L.F. Sharanda, Y.V. Plyuto, I.V. Babich, I.V. Plyuto, A.P. Shpak, J. Stoch, and J.A. Moulijn, Applied Surface Science 252 (2006) 8549-8556.

[23] D.W. McKee, Carbon 23 (1985) 707-713.

[24] K. Nagaoka, K. Seshan, K. Takanabe, and K.-i. Aika, Catalysis Letters 99 (2005) 97-100.

[25] C. Padeste, N.W. Cant, and D.L. Trimm, Catalysis Letters 18 (1993) 305-316.

[26] Q. Fu, H. Saltsburg, and M. Flytzani-Stephanopoulos, Science 301 (2003) 935-938.

[27] G. Jacobs, L. Williams, U. Graham, D. Sparks, and B.H. Davis, The Journal of Physical Chemistry B 107 (2003) 10398-10404.

[28] F.C. Meunier, D. Tibiletti, A. Goguet, D. Reid, and R. Burch, Applied Catalysis A: General 289 (2005) 104-112.

[29] R.T. Hamilton, D.A. Sams, and F. Shadman, Fuel 63 (1984) 1008-1012.

[30] G. Domazetis, J. Liesegang, and B.D. James, Fuel Processing Technology 86 (2005) 463-486.

[31] Y. Otake, and P.L. Walker Jr, Fuel 72 (1993) 139-149.

[32] T. Takarada, J. Sasaki, Y. Otsuka, Y. Tamai, and A. Tomita, Industrial \& Engineering Chemistry Research 26 (1987) 627-629.

[33] A.L. Kustov, A.M. Frey, K.E. Larsen, T. Johannessen, J.K. Nørskov, and C.H. Christensen, Applied Catalysis A: General 320 (2007) 98-104.

[34] D. Haffad, A. Chambellan, and J.C. Lavalley, Journal of Molecular Catalysis A: Chemical 168 (2001) 153-164.

[35] F. Sadi, D. Duprez, F. Gérard, and A. Miloudi, Journal of Catalysis 213 (2003) 226-234.

[36] G. Vlaic, R. Di Monte, P. Fornasiero, E. Fonda, J. Kaspar, and M. Graziani, Journal of Catalysis 182 (1999) 378-389.

[37] J.J. Pis, J.A. Menéndez, J.B. Parra, and R. Álvarez, Fuel Processing Technology 77-78 (2002) 199-205.

[38] B. Arias, C. Pevida, F. Rubiera, and J. Pis, Journal of Thermal Analysis and Calorimetry 90 (2007) 859-863.

[39] B. Matas Güell, I. Babich, K.P. Nichols, J.G.E. Gardeniers, L. Lefferts, and K. Seshan, Applied Catalysis B: Environmental 90 (2009) 38-44. 
[40] K.G. Azzam, I.V. Babich, K. Seshan, and L. Lefferts, Journal of Catalysis 251 (2007) 153-162.

[41] R.J. Tyler, Fuel 58 (1979) 680-686. 


\section{Chapter 8}

Conclusions and recommendations 

The design of effective catalysts for steam reforming of pyrolysis oil is a challenging but essential step in the production of renewable hydrogen from biomass. In industry, steam reforming is typically carried out over nickel-based catalysts, as they appear to be the most cost-effective. However, these catalysts are very susceptible to coking, resulting in severe catalyst deactivation.

In this work, the development of an active and stable catalyst for the steam reforming of pyrolysis oil was based on studies using model compounds in order to simplify relations between structure, properties and reaction mechanism.

The first part of this thesis focuses on the steam reforming of acetic acid over platinum-based and nickel-based catalysts, acetic acid being a model system for light oxygenates present in pyrolysis oil. A detailed isotopic study of acetic acid activation on $\mathrm{Pt} / \mathrm{C}$ validated and completed the bifunctional mechanism for the steam reforming of acetic acid over a $\mathrm{Pt} / \mathrm{ZrO}_{2}$ catalyst. Acetic acid activation occurs on Pt via $\mathrm{C}-\mathrm{C}$ cleavage, resulting in $\mathrm{CH}_{3}$ species whereas water is activated on the metal oxide, $\mathrm{ZrO}_{2}$, by forming hydroxyl groups which reform the $\mathrm{CH}_{3}$ species formed on the $\mathrm{Pt}$ surface.

Catalytic results revealed that catalyst stability, affected negatively by deposition of carbonaceous species (coke), is strongly influenced by the nature of the catalyst support. Presence of small amounts of oxygen in the feed has a significant influence on catalyst deactivation caused by coking. A comparison between the catalytic performance of $\mathrm{Pt} / \mathrm{ZrO}_{2}$ and $\mathrm{Pt} / \mathrm{CeO}_{2}$ in the absence and presence of oxygen clearly indicated that ceria, an oxide with red-ox capability, improves catalyst stability significantly under oxidative conditions by minimizing coke accumulation on the catalyst surface. This is explained by the combination of (i) enhanced steam reforming activity of a coke precursor (acetone), (ii) oxygen addition to the steam reforming feed and (iii) the red-ox characteristics of $\mathrm{CeO}_{2}$ to use both oxygen and water as oxidants. Additional experiments using acetone over both supports can give a closer insight into the mechanism. This would allow clarifying whether the better resistance of $\mathrm{Pt} / \mathrm{CeO}_{2}$ to coke is also due to lower amounts of acetone formation via acetic acid condensation or its removal via gasification on $\mathrm{CeO}_{2}$ as compared to $\mathrm{ZrO}_{2}$. 
Additionally, experiments in order to influence selective combustion of coke are recommended. This could be achieved by (i) varing oxygen amounts in the feed, (ii) catalyst modification and (iii) type of oxidants such as $\mathrm{H}_{2} \mathrm{O}_{2}$.

Over nickel-zirconia-based catalysts, catalyst stability is also influenced significantly by modifying the support $\left(\mathrm{ZrO}_{2}\right)$ with the presence of potassium and lanthanum as catalyst promoters. The un-promoted catalyst $\left(\mathrm{Ni} / \mathrm{ZrO}_{2}\right)$ deactivates gradually in time, affecting specially the water-gas shift reaction. Coke formation as well as a competitive adsorption of reactants is suggested to be responsible for the catalyst deactivation. Addition of potassium and/or lanthanum improves catalyst stability to a large extent. Characterization results (temperature program oxidation and $\mathrm{X}$-ray diffraction measurements) suggested that potassium enhances gasification of carbonaceous species by facilitating the formation of reactive hydroxyl groups and lanthanum enhances coke combustion by forming an oxy-carbonate phase $\left(\mathrm{La}_{2} \mathrm{O}_{2} \mathrm{CO}_{3}\right)$ during reaction. In order to understand in more detail the role of the promoters in catalyst stability, information about the surface composition needs further attention. Evaluation of the relative presence of each promoter at the surface is recommended.

In the second part of the thesis, steam reforming of phenol as a model component of heavy oxygenates present in pyrolysis oil was investigated over $\mathrm{Ni} / \mathrm{K}-\mathrm{La}-\mathrm{ZrO}_{2}$ and $\mathrm{Ni} / \mathrm{Ce}-\mathrm{ZrO}_{2}$. Similar to the observations on the steam reforming of acetic acid, the nature of the oxide support influences catalyst stability remarkably, as evidenced by the difference in water-gas shift deactivation between the two catalysts. $\mathrm{Ni} / \mathrm{Ce}-\mathrm{ZrO}_{2}$ deactivates to a lesser extent than $\mathrm{Ni} / \mathrm{K}-\mathrm{La}-\mathrm{ZrO}_{2}$. The lower accumulation of carbonaceous deposits on the nickel surface of $\mathrm{Ni} / \mathrm{Ce}-\mathrm{ZrO}_{2}$ as compared to $\mathrm{Ni} / \mathrm{K}-\mathrm{La}-\mathrm{ZrO}_{2}$ in combination with the high activity exhibited for the water-gas shift by unsupported nickel is proposed to justify the better stability of $\mathrm{Ni} / \mathrm{Ce}-\mathrm{ZrO}{ }_{2}$. Further, it is speculated that the red-ox properties of the $\mathrm{Ce}-\mathrm{ZrO}_{2}$ allow nickel surface to remain clean from carbonaceous deposits in the case of $\mathrm{Ni} / \mathrm{Ce}-\mathrm{ZrO}_{2}$, and therefore is able to perform the water-gas shift reaction without suffering from deactivation. In contrast, $\mathrm{K}-\mathrm{La}-\mathrm{ZrO}_{2}$ does not possess red-ox capability and therefore the nickel surface is covered with carbonaceous deposits to a large extent, resulting in catalyst deactivation for the water-gas shift reaction. Although it has been demonstrated the 
importance of the location of coke on the catalyst surface, more knowledge in the formation of carbonaceous species from heavy oxygenates such as phenol is essential to further improve catalyst stability. MALDI-TOF MS experiments of used catalysts would allow identification of carbonaceous species originating from phenol which in turn would allow us establishing the catalytic routes responsible for coke formation. Additionally, in future work, catalyst stability should be tested with lower steam to carbon ratios to mimic the severe conditions in which pyrolysis oil should be industrially reformed.

The last part of this thesis addresses char formed during pyrolysis oil evaporation as a novel model component of pyrolysis oil since, as reported in this work, pyrolysis oil evaporation is always coupled with the formation of char. Characterization results revealed that char consists of a very light/fluffy structure, which results in elutriation with gas streams from the reactor if char is not sufficiently bounded to a carrier. It was concluded that temperature at which char is produced influences the reactivity of char remarkably. Char produced at temperatures higher than $650-700{ }^{\circ} \mathrm{C}$ undergoes a significant aging process, resulting in a low reactive char.

Steam and $\mathrm{CO}_{2}$ gasification of char were presented as promising routes to enhance char removal during pyrolysis oil evaporation. The rate of steam gasification for char produced at relatively low temperatures $\left(525^{\circ} \mathrm{C}\right)$ appeared to be too low at the temperature range $\left(500-700{ }^{\circ} \mathrm{C}\right)$ desired for pyrolysis oil evaporation. However, the presence of a ceria-zirconia-based catalyst enhanced the char gasification rates to a large extent for both steam and $\mathrm{CO}_{2}$ gasification. The red-ox properties of the catalyst were suggested to play an important role by allowing oxygen mobility and activation of steam and $\mathrm{CO}_{2}$. Additionally, XPS and SEM characterization studies showed the significant influence of the catalyst in the nature of char formed during pyrolysis oil evaporation. Char formed in the presence of the ceria-zirconia catalyst is more oxygenated and thus more reactive. Good contact between char and catalyst is essential for the catalytic enhancement in char gasification. It was concluded that pyrolysis oil evaporation in combination with internal catalytic char gasification is feasible at relatively low temperatures $\left(\leq 700{ }^{\circ} \mathrm{C}\right)$. 
However, several key issues need further attention. The catalyst/pyrolysis ratio should be optimized. Large droplets of oil would result in poor heat transfer. Additionally, if the droplets of oil are larger than catalyst particles, an external surface of char around the catalyst particle would be formed, resulting in poor contact between char and catalyst and low reactivity of char. Development of a high surface area ceria-zirconia catalyst is suggested for future work, as it would allow impregnation of larger amounts of oil in each catalyst particle. The positive aspect of evaporating pyrolysis oil with large droplets is that oil would be very well distributed inside the catalyst particle. On the contrary, oil droplets smaller than catalyst particles would not be sufficient to impregnate catalyst particles completely, resulting in low reactivity of char. However, heat transfer would be good, in contrast to large oil droplets.

Another aspect that needs to be optimized is the temperature at which char is formed. On the one hand, temperature has to be high enough for oil to evaporate but on the other hand, too high temperatures decrease the reactivity of char due to an aging process. This process was only studied in absence of catalyst. Therefore, further work to investigate to which extent char undergoes aging in the presence of ceria-zirconia is recommended.

A crucial aspect of a catalyst, when used in fluidized beds is its mechanical strength. Therefore, verification of the mechanical strength of the ceria-zirconia catalyst is highly recommended.

Solutions to all these aspects will give a possibility to an efficient process for steam reforming of pyrolysis oil. 


\section{Publications}

B. Matas Güell, G. van Rossum, W. P. M. van Swaaij, S. R. A. Kersten, L. Lefferts and $\mathrm{K}$. Seshan, Challenges in the production of sustainable fuels from pyrolysis oil - Design of efficient catalysts for gasification of char. Fuels (submitted).

G. van Rossum, B. Matas Güell, R.P.B. Ramachandran, K. Seshan, L. Lefferts, W.P.M. van Swaaij, and S.R.A. Kersten, Evaporation of pyrolysis oil: product distribution and residue char analysis. $A I C h E$ (submitted).

B. Matas Güell, I. Babich, L. Lefferts and K. Seshan. Steam reforming of phenol over Ni-based catalysts - A comparative study. Applied Catalysis (to be submitted).

B. Matas Güell, I. Babich, K.P. Nichols, J.G.E. Gardeniers, L. Lefferts and K. Seshan. Design of a stable steam reforming catalyst - A promising route to sustainable hydrogen from biomass oxygenates. Applied Catalysis B: Environmental 90 (2009) 38-44.

B. Matas Güell, I. M. Torres da Silva, K. Seshan and L. Lefferts. Sustainable route to hydrogen - Design of stable catalysts for the steam gasification of biomass related oxygenates. Applied Catalysis B: Environmental 88 (2009) 59-65.

B. Matas Güell, I. Babich, K. Seshan and L. Lefferts. Steam reforming of biomass based oxygenates-Mechanism of acetic acid activation on supported platinum. Journal of Catalysis 257 (2008) 229-231. 



\section{Acknowledgements}

The long journey initiated in The Netherlands almost five years ago is now reaching the end.

Above all, this rewarding experience has given me the opportunity to enrich myself and to meet many people who filled my days with sense and joy. I would like to express my deep acknowledgements to everyone who contributed to make a dream come true.

I would like to start giving my special thanks to my promoter Prof. dr. ir. Leon Lefferts who gave me the opportunity to contribute to the catalytic field while broadening my knowledge. Thank you for your encouragement and criticism.

My deep thanks also to Dr. Seshan, my assistant promoter and beyond, my daily supervisor. Thank you for your guidance through our research project and for the fruitful scientific discussions. Thanks for your understanding and support during difficult periods of my $\mathrm{PhD}$.

This work could not have been a reality without the contribution of Dr. Igor Babich. First of all I want to thank you for your scientific input in this work. You always helped me to see problems as challenges. But besides work, I especially want to thank you for your time sharing wonderful conversations about chess, Jana, Marius, life, anything. You listened to me when I needed it. Thanks for making me feel as part of your family. I truly appreciate all you have done. Дякую.

I am very grateful to Dr. Barbara Mojet. Being my supervisor during my Erasmus certainly allowed me to gain experience from you, as a scientist and as a person. You were a turning point in my decision to stay in The Netherlands for a $\mathrm{PhD}$. From that point and up to date we have built up a strong friendship which has helped me in many aspects during these four years. You will always be in my heart. 
Dr. Jan van Ommen, thanks for all our discussions. Starting with catalysis, going through diving, and ending up talking about "magic" places in my lovely Empordà. It kept melancholy on a side.

Dr. Arie van Houselt, thanks for sharing interesting topics during lunch times.

Now it's time to express my gratitude to all my colleagues and friends in Enschede for their support. Being abroad for such a long time makes this boost of energy indispensable; without it, I would not have made it. Bertolino, thanks for all the technical support in any field: set-ups, bikes, computers, and specially this thesis....you were essential in this work, "The master". Sharing interesting and deep discussions with you during borrel has been a pleasure! Dear Lianne (honey bee), we understood each other so well from a beginning....I really appreciate every single moment we shared together. You transferred me your delightful spirit. Karin, thanks for being always available when I needed your help. You are always willing to arrange social events for the group; keep it up. Louise, thanks for nice chats and measurements. Jeroen, your support during my experiments in Langezijds helped me out in many occasions. Sabine, thanks for helping me out arranging meetings and paperwork during the last months of my $\mathrm{PhD}$. Martine, it was nice sharing sunshine in the park during my last days at CPM!

$\mathrm{Kazu}$, it was only for a couple of months, but it was enough to get along with you very easily, helping me a lot to adjust to a new dutch life. Sune, you became my best friend during the first 2 years of my PhD. Since you left, I have missed our coffee times either chatting, watching movies or resolving sudokus. I will never forget the great time we had together...and hopefully more to come in a future. Fra, you also left a couple of years ago....and since then I have also missed our special Italian-Spanish chats...and your enthusiastic mood. I admire you so much, strong woman!!!! Dejan, you were so right... a $\mathrm{PhD}$ always ends up working during weekends. Thanks for your advices; they were very useful. Cristiano, your liveliness brought wonderful moments in CPM. I enjoyed them very much. I am sure we will still be in touch to enjoy these moments again, even being away from CPM; baci! Khalid, thanks for helping me out in the beginning of my PhD. Iris, thanks for your contribution to this work but even more important for your presence in CPM, which was full of positive energy. That 
helped me a lot! Hans, we did not share many moments during the $\mathrm{PhD}$ but those in Belfast were really cool. Patrick, it took some time, but in the end we shared many coffees and conversations together. You even convinced me to go to a concert of dutch DJ's!

Kumar, almost 5 years since we met. We have shared loads of dinners, parties and a lot of fun. It is a pitty that everything reaches an end. Davide, you have been like a brother to me, especially in the last 2 years. Thanks for caring about me. You have been always there, to motivate me, to make me smile and to support me until the end to accomplish this great achievement. Grazie mille!! Guuzzie, I do not have enough words to thank you for all the support, help and encouragement you have given to me. Besides building up a thesis in parallel, we have also built up a strong friendship. Thanks for being that trustable friend anytime. Dank je well.

Gacia, it took some time to get to know you deeply but since then I have enjoyed our girly dinners, discussions about having boyfriends abroad, shopping, etc. to the maximum. Thanks for your cheerful times and for having you as a friend. Let's take our life easy. Vijay, borrels have been the meeting point to get to know you a bit better. I have always learned something from your conversations. Sergio, gracias por tus saludos matinales en mi querida lengua catalana. Eso siempre ayuda a iniciar el día con buen pie. Liza, keep your energetic strength, it is awesome. Hrudya, always a pleasure to listen to your Indian stories. A fascinating culture to me. Marijana, kakosi? Since you came I have felt more alive in the group...even though we have shared only one year and a half, we have shared many things already, enough for me to realize how great you are. Today, you are even standing on the stage next to me, supporting me until the end. Thanks bella. I feel that we will always be in touch. Inga, no cambies tu positividad y tu forma de ser: ambas son geniales por sorprendentes. Son, keep your smile. It transfers good energy. Dennis, always willing to help; thanks! Željko, thanks for all your suggestions concerning my thesis. I appreciate it a lot.

I would also like to thank Dr. Matthijn Dekkers, Gerard Kip, Dr. Mark Smithers and Dr. Rico Keim for characterization experiments.

M'agradaria donar les gràcies a tots els estudiants Erasmus que han passat pel grup durant aquests anys i m’han donat el seu suport: Albert, Sònia, Àngel, Núria, 
Rubén, Gemma, Noelia, Arnau i Jordi (qui ens havia de dir que la nostra amistat arribaria tan lluny, avui ets un dels meus "paranimfs". T'agraeixo de tot cor tot el que has fet per mi.)

I also would like to give my thanks to those close friends outside work who transferred me the energy to go through this $\mathrm{PhD}$ keeping my spirit: Laila Beate og Kristina, tusen takk for alle; Masha, you kept me alive in this city, spasiva. Also foreign friends in Enschede: Ferran, Michael, Uros, Laura. Almu, nuestras charlas por skype me han ayudado mucho durante todo el doctorado. Gracias! A la gent catalana: Calsberg, Tenyol, Clàudia, Lourdes, Plein, Utxu, Ballbè, moltes gràcies pel suport donat durant aquests eterns 4 anys. Les visites s' han agraït molt!!

Finalment vull agrair a la família. Als Güell....la pinya creada és indescriptible i el caliu trobat cada vegada que he aterrat a Corçà $m$ ' ha donat forces per tirar endavant des d' un bon principi; als Matas...m' he sentit molt estimada durant aquests anys...la distància no ha pogut amb nosaltres, gràcies de tot cor! Àvia Anna Maria i Dolors, us vaig haver de despedir durant el doctorat de forma inesperada...aquesta tesi també va per a vosaltres...us tindré sempre molt present en el meu cor.

Marius, that november was a turning point in my life...It has been hard but we have accomplished it! Thanks so much for all your support, energy, visits, and for no doubting in any moment I and we would make it. This chapter of my life would not have been closed without you. T'estimo!

Blanx, mai hagués pensat que poguéssim compartir més enllà de la germanor. Et tinc com a una gran amiga i persona a considerar. Sense el teu suport, les teves visites i la teva força en les paraules, no ho hagués aconseguit. T'estimo, girasol.

Mare i Pare, no tinc paraules per descriure el suport donat durant aquests anys....la distància ens ha enfortit. Les visites anuals plenes de joia i felicitat, els xats de bon matí, les trucades...no m' heu deixat sola en cap moment. Heu de tenir present que no és la meva tesi sinó la nostra tesi. Us estimo amb deliri. 




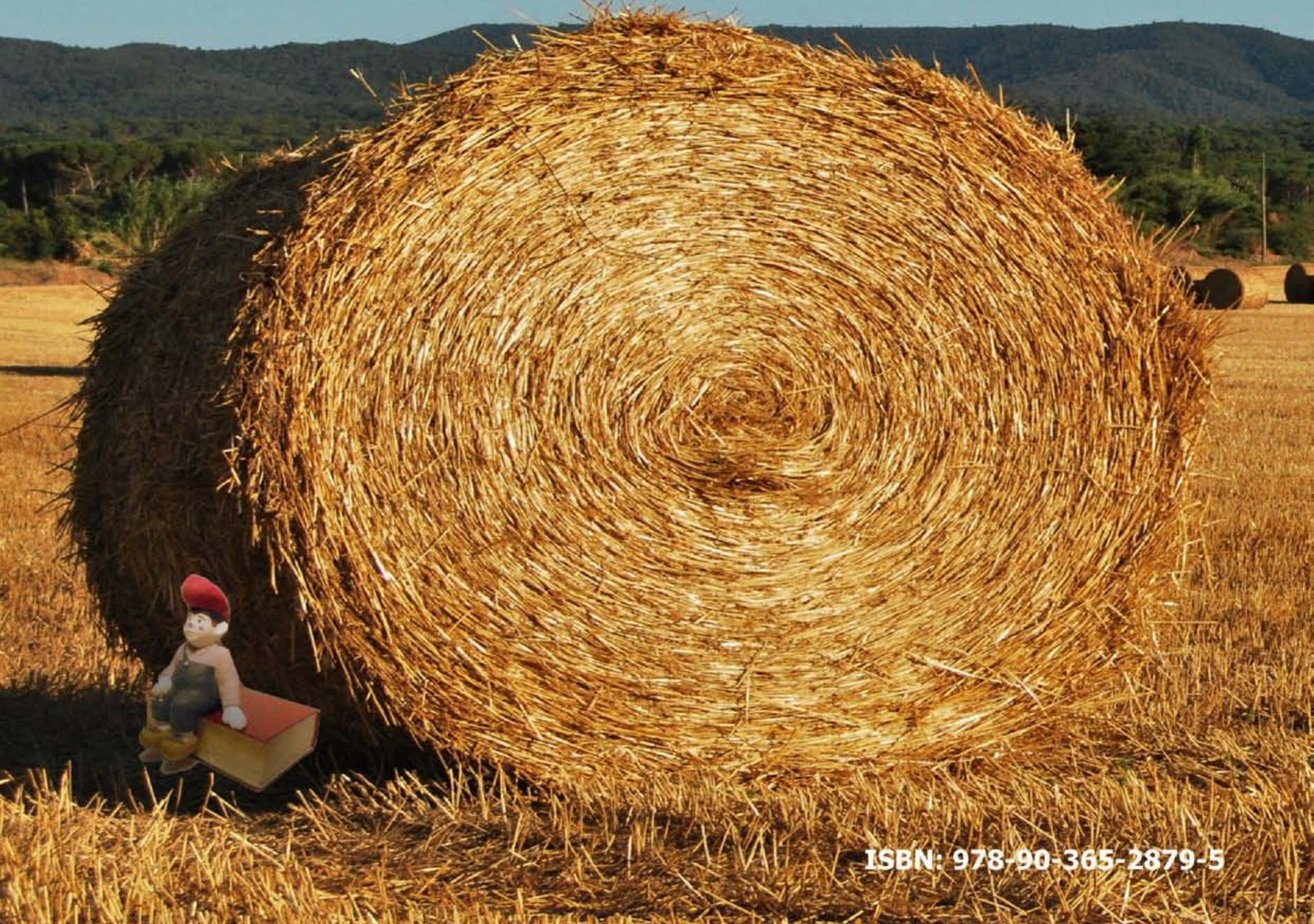

